$a>\leq n$

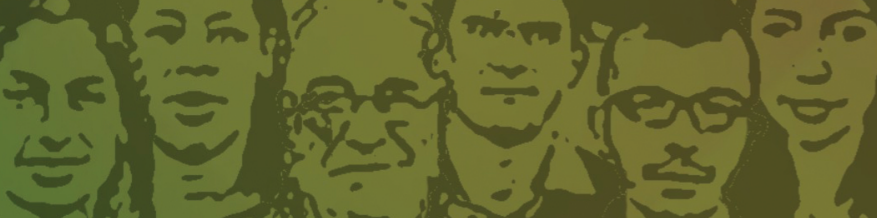

wh

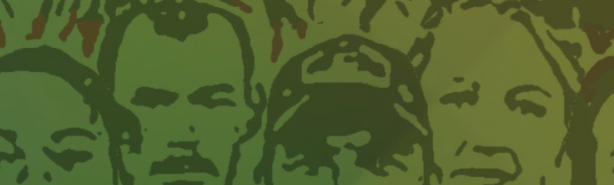
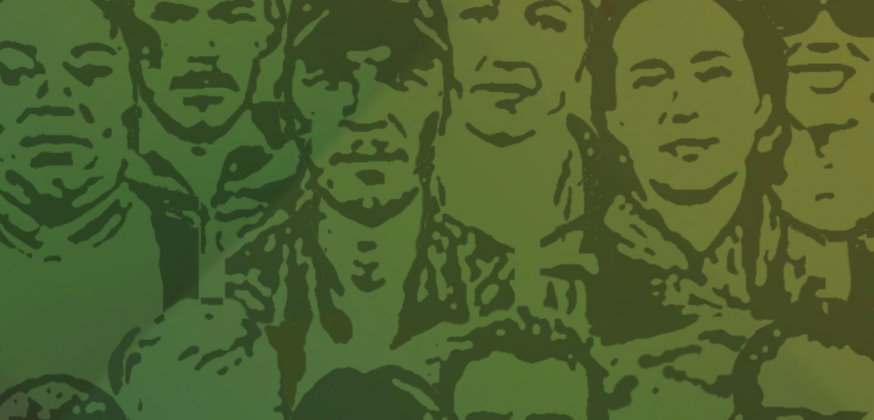

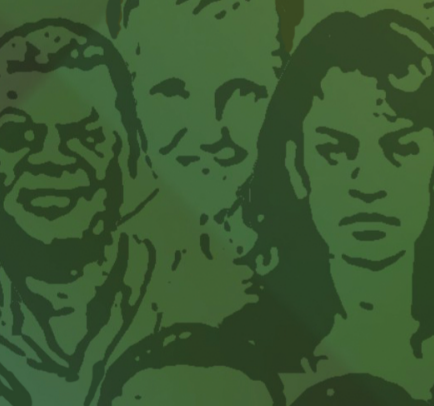
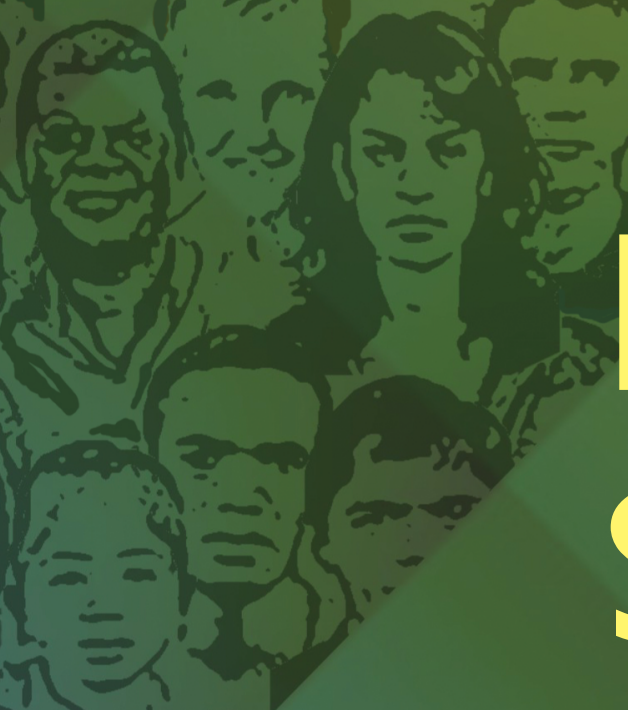

$8=$

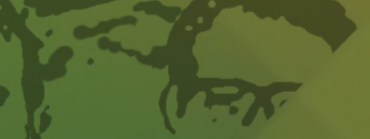

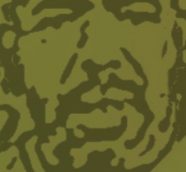

José Carvalho de Noronha Sulamis Dain Telma Ruth Pereira

organizadores

Paulo Gadelha

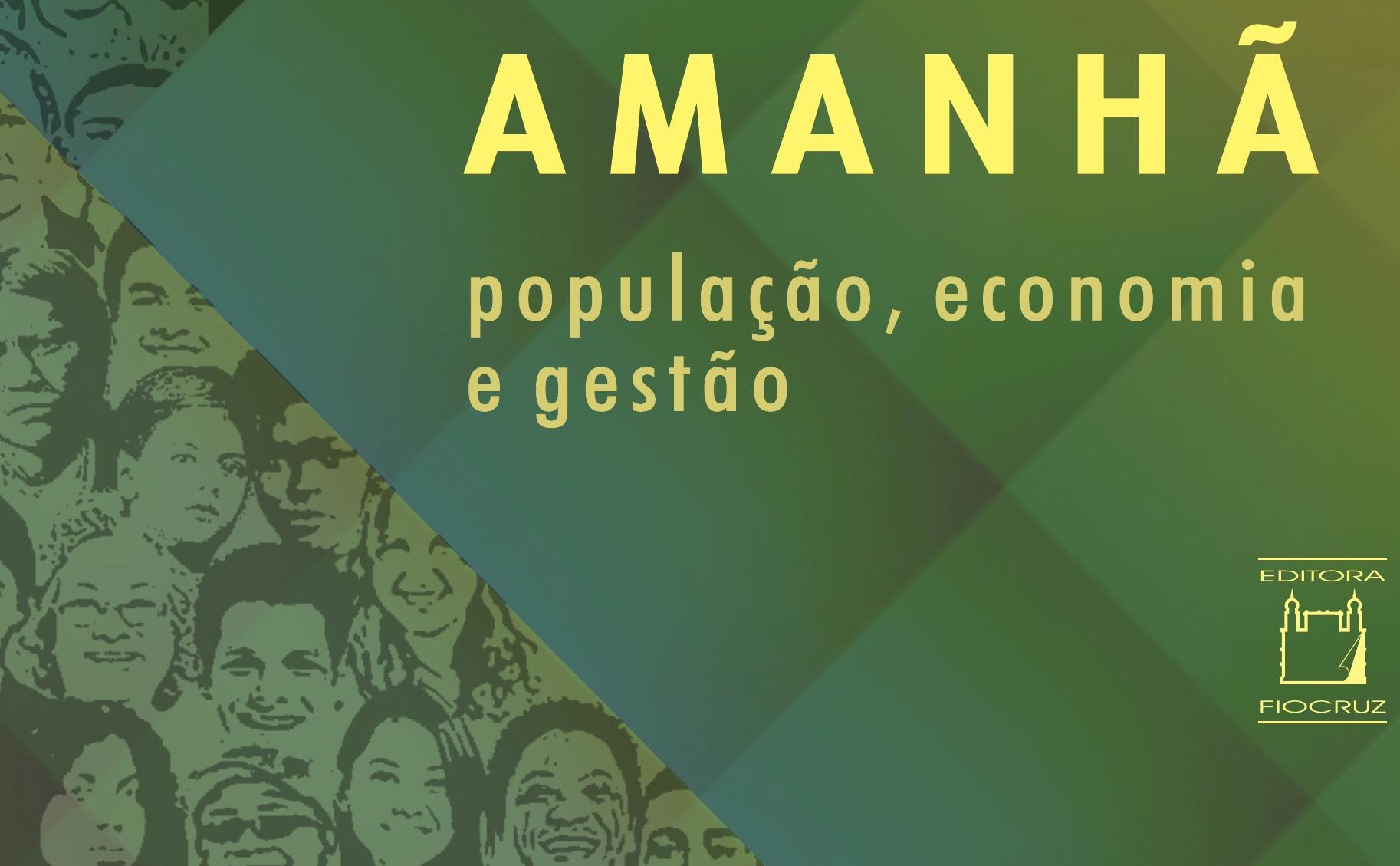



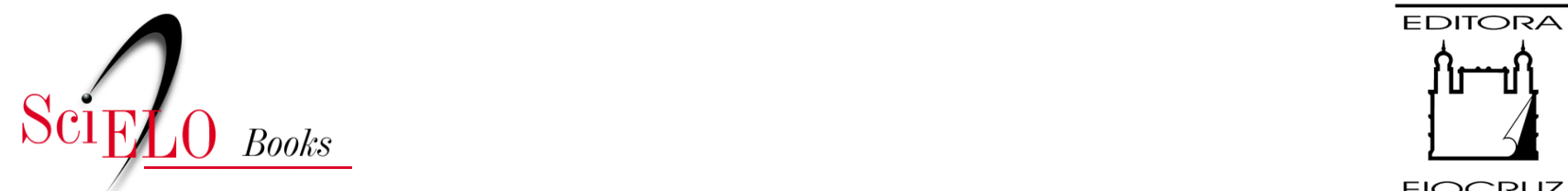

FIOCRUZ

\title{
Brasil Saúde Amanhã população, economia e gestão
}

\author{
Paulo Gadelha \\ José Carvalho de Noronha \\ Sulamis Dain \\ Thelma Ruth Pereira \\ (orgs.)
}

\section{SciELO Books / SciELO Livros / SciELO Libros}

GADELHA, P., NORONHA, J.C., DAIN, S., and PEREIRA, T.R., eds. Brasil Saúde Amanhã: população, economia e gestão [online]. Rio de Janeiro: Editora FIOCRUZ, 2016, 224 p. ISBN: 97865-5708-093-1. https://doi.org/10.7476/9786557080931.

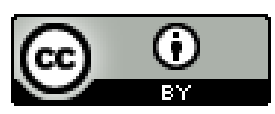

All the contents of this work, except where otherwise noted, is licensed under a Creative Commons Attribution $\underline{4.0 \text { International license. }}$

Todo o conteúdo deste trabalho, exceto quando houver ressalva, é publicado sob a licença Creative Commons Atribição 4.0.

Todo el contenido de esta obra, excepto donde se indique lo contrario, está bajo licencia de la licencia $\underline{\text { Creative }}$ Commons Reconocimento 4.0. 


\section{B R A S I L SA Ú DE A M A N H Ã população, economia e gestão}




\section{FUNDAÇÃO OSWALDO CRUZ}

Presidente

Paulo Gadelha

Vice-Presidente de Ensino,

Informação e Comunicação

Nísia Trindade Lima

EDITORA FIOCRUZ

Diretora

Nísia Trindade Lima

Editor Executivo

João Carlos Canossa Mendes

Editores Científicos

Carlos Machado de Freitas

Gilberto Hochman

Conselho Editorial

Claudia Nunes Duarte dos Santos

Jane Russo

Ligia Maria Vieira da Silva

Maria Cecília de Souza Minayo

Marilia Santini de Oliveira

Moisés Goldbaum

Pedro Paulo Chieffi

Ricardo Lourenço de Oliveira

Ricardo Ventura Santos

Soraya Vargas Côrtes 
Paulo Gadelha

José Carvalho de Noronha

Sulamis Dain

Thelma Ruth Pereira

organizadores

\section{B R A S I L \\ SA Ú DE \\ A M A N H Ã \\ população, economia \\ e gestão}

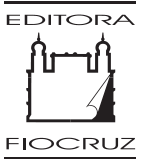


Copyright (C) 2016 dos autores

Todos os direitos desta edição reservados à

FUNDAÇÃO OSWALDO CRUZ / EDITORA

Revisão e copidesque

M. Cecilia G. B. Moreira

Normalização e referências

Clarissa Bravo

Capa e projeto gráfico

Carlota Rios

Produção gráfico-editorial

Phelipe Gasiglia

Catalogação na fonte

Instituto de Comunicação e Informação Científica e Tecnológica em Saúde/Fiocruz

Biblioteca de Saúde Pública

B823b

Brasil Saúde Amanhã: população, economia e gestão. / organizado por Paulo Gadelha, José Carvalho de Noronha, Sulamis Dain et al. Rio de Janeiro: Editora FIOCRUZ, 2016

224 p.: il.; tab.; graf.; mapas

ISBN: 978-85-7541-484-2

1. Dinâmica Populacional. 2. Distribuição Espacial da População.

3. Acesso aos Serviços de Saúde. 4. Administração Pública.

5. Financiamento da Assistência à Saúde. 6. Serviços de Saúde.

7. Setor Privado. 8. Brasil. I. Gadelha, Paulo (Org.). II. Noronha, José Carvalho de (Org.). III. Dain, Sulamis (Org.). IV. Título.

2016

EDITORA FIOCRUZ

Av. Brasil, 4036, térreo, sala 112 - Manguinhos

21040-361 - Rio de Janeiro, RJ

Tels: (21) 3882-9039 / 3882-9041

Telefax: (21) 3882-9006

e-mail: editora@fiocruz.br

http://www.fiocruz.br

Editora filiada

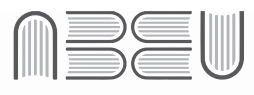

Associação Brasileira das Editoras Universitárias 


\section{AUTORES \& ORGANIZADORES}

\section{Antônio Tadeu Ribeiro de Oliveira}

Estatístico, doutor em demografia pela Universidade Estadual de Campinas, com pós-doutorado no Departamento de Ecologia Humana e População da Universidade Complutense de Madri; pesquisador do Instituto Brasileiro de Geografia e Estatística.

\section{Célio Hiratuka}

Economista, doutor em ciência econômica pela Universidade Estadual de Campinas (Unicamp); professor da Unicamp e pesquisador do Núcleo de Economia Industrial e da Tecnologia do Instituto de Economia da mesma universidade.

\section{Fernando Sarti}

Economista, doutor em economia pela Universidade Estadual de Campinas (Unicamp); professor do Instituto de Economia (IE) da Unicamp e pesquisador do Núcleo de Economia Industrial e da Tecnologia do IE/Unicamp e da Rede Mercosul.

\section{Flávia de Paula Duque Brasil}

Arquiteta e urbanista, doutora em sociologia pela Universidade Federal de Minas Gerais; professora e pesquisadora da Escola de Governo Professor Paulo Neves de Carvalho da Fundação João Pinheiro.

\section{José Carvalho de Noronha (organizador)}

Médico sanitarista, doutor em saúde coletiva pela Universidade do Estado do Rio de Janeiro; médico do Laboratório de Informações em Saúde do Instituto de Comunicação e Informação Científica e Tecnológica da Fundação Oswaldo Cruz (Fiocruz), coordenador executivo da iniciativa Brasil Saúde Amanhã da Fiocruz.

\section{Kleber Pacheco de Castro}

Economista, mestre em economia pelo programa de pós-graduação em economia da Universidade Federal Fluminense e doutorando em economia do programa de pós-graduação em ciências econômicas da Universidade do Estado do Rio de Janeiro; consultor em finanças públicas.

\section{Marco Antonio Martins da Rocha}

Economista, doutor em ciências econômicas pelo Instituto de Economia da Universidade Estadual de Campinas (IE/Unicamp); pesquisador do Núcleo de Economia Industrial e da Tecnologia do IE/Unicamp.

\section{Maria Lucia Werneck Vianna}

Socióloga, doutora em ciência política pelo Instituto Universitário de Pesquisas do Rio de Janeiro; professora do programa de pós-graduação em políticas públicas e estratégias de desenvolvimento do Instituto de Economia da Universidade Federal do Rio de Janeiro. 


\section{Maria Monica Vieira Caetano O’Neill}

Geógrafa, doutora em geografia pelo programa de pós-graduação em geografia da Universidade Federal do Rio de Janeiro; pesquisadora do Instituto Brasileiro de Geografia e Estatística.

\section{Paulo Gadelha (organizador)}

Médico, doutor em saúde pública pela Escola Nacional de Saúde Pública Sergio Arouca da Fundação Oswaldo Cruz (Fiocruz); pesquisador titular e presidente da Fiocruz.

\section{Ricardo Carneiro}

Matemático, doutor em ciências humanas pela Universidade Federal de Minas Gerais; professor e pesquisador da Escola de Governo Paulo Neves de Carvalho da Fundação João Pinheiro.

\section{Salvador Werneck Vianna}

Economista, doutor em economia pela Universidade Federal do Rio de Janeiro; pesquisador do Instituto de Pesquisa Econômica Aplicada.

\section{Sulamis Dain (organizadora)}

Economista, doutora em economia pela Universidade Estadual de Campinas e livre-docente pela Universidade Federal do Rio de Janeiro; professora colaboradora das Faculdades de Campinas.

\section{Telma Ruth Pereira (organizadora)}

Médica; colaboradora da iniciativa Brasil Saúde Amanhã da Fundação Oswaldo Cruz.

\section{Wanderley Guilherme dos Santos}

Filósofo, doutor em ciência política pela Stanford University (EUA); pesquisador sênior da Universidade do Estado do Rio de Janeiro, professor aposentado da Universidade Federal do Rio de Janeiro. Foi professor e fundador do Instituto Universitário de Pesquisas do Rio de Janeiro. 
1. Brasil Amanhã: cenários políticos

Wanderley Guilherme dos Santos

2. Dinâmica Demográfica e Distribuição Espacial da População:

o acesso aos serviços de saúde

Antônio Tadeu Ribeiro de Oliveira

Maria Monica Vieira Caetano O’Neill

3. Gestão Pública no Brasil do Século XXI:

tendências reformistas e o desafio da profissionalização

Ricardo Carneiro

Flávia de Paula Duque Brasil

4. Qual Padrão de Desenvolvimento? Cenários macroeconômicos a longo prazo

Salvador Werneck Vianna

Maria Lucia Werneck Vianna

5. Alternativas para o Financiamento da Saúde pela União:

espaço fiscal e oportunidades para as próximas duas décadas

Sulamis Dain

Kleber Pacheco de Castro

6. Mudanças Recentes no Setor Privado de Serviços de Saúde no Brasil: internacionalização e financeirização

Célio Hiratuka

Marco Antonio Martins da Rocha

Fernando Sarti 



\section{PREFÁCIO}

Pensar o futuro constitui um desafio para os órgãos de governo e a sociedade em geral, porque a pressão do presente na resolução dos problemas imediatos configura-se como preocupação dominante. Embora compreensível, esta realidade não isenta os atores políticos e sociais de se envolverem com as questões do futuro.

No Brasil, a tradição sempre foi desenvolver políticas de curto prazo, por meio de planos em que os cenários são temporalmente limitados, circunscritos, de uma maneira geral, a um período de mandato.

Trabalhar sobre o futuro pode proporcionar oportunidades para influenciá-lo de acordo com propósitos definidos, afastando os trajetos de potenciais desvios indesejáveis. Portanto, a prospecção estratégica torna possível identificar tendências, construir indicadores e intervir na realidade. Antecipar o futuro, de forma fundamentada, consiste em ampliar os limites do horizonte de intervenção. Na construção de um plano, a previsão é um elemento central para o êxito desse processo.

Prever é construir uma política que articule o desenvolvimento econômico, social e ambiental, e que integre a análise com o rastreamento de horizontes desejados. Mesmo considerando que projeções possam ser formuladas com base em tendências, especular sobre o futuro ou visualizar o cenário para uma determinada área pode incluir um grau de incerteza grande, haja vista as mudanças que ocorrem no cenário internacional ou mesmo mudanças políticas radicais. No entanto, isso não invalida a importância do exercício da prospecção como uma reflexão permanente sobre a realidade.

É louvável a iniciativa da Fundação Oswaldo Cruz (Fiocruz) de estabelecer uma rede de pesquisa multi e interdisciplinar, com o objetivo de buscar caminhos e direções para o setor Saúde no Brasil, utilizando metodologia e ferramentas de prospecção. A saúde é um campo que extrapola a mera relação entre serviços e pacientes. Ela é dependente e caudatária de influências dos mais variados setores da sociedade, como a economia, a indústria, a cultura, a produção de alimentos, o desenvolvimento científico e tecnológico, o saneamento básico e ambiental, as mudanças demográficas, entre outros.

O livro Brasil Saúde Amanhã: população, economia e gestão abrange campos de aplicação de conhecimentos que impactam diretamente na saúde, e, nesse sentido, o exercício de prospecção passa a ser uma reflexão maior, ou seja, busca pensar o país. Aqui o leitor encontrará ensaios que trabalham 
sobre a probabilidade de futuros para a saúde em um contexto de políticas econômicas e sociais, abarcando temas como cenários políticos, demografia, gestão pública e aspectos macroeconômicos.

Com este passo a Fiocruz se habilita a participar ativamente do planejamento nacional de longo prazo no campo das políticas de saúde, contribuindo para a discussão das opções estratégicas do país, a partir da situação presente, e considerando as possibilidades do futuro, com base na elaboração de subsídios para a preparação de ações de governo. E, ainda, cumpre sua missão de produzir, disseminar e compartilhar conhecimentos e tecnologias voltados para o fortalecimento e a consolidação do Sistema Único de Saúde (SUS).

José Gomes Temporão

Doutor em saúde coletiva pela Universidade do Estado do Rio de Janeiro, ministro da Saúde (março de 2007 a janeiro de 2011) 


\section{APRESENTAÇÃO}

Em raros momentos de sua história o Brasil desenvolveu o planejamento de longo prazo para a formulação de políticas públicas. Os governos, quando muito, tendem a concentrar seus esforços na elaboração de planos plurianuais, definindo programas prioritários e orientando o gasto orçamentário para um horizonte de quatro anos. Com frequência, esses planos revelam projeções simples de tendências e traduzem alguns projetos prioritários geralmente circunscritos ao período de gestão.

A criação da Secretaria de Assuntos Estratégicos (SAE) da Presidência da República, em 2008, representou um esforço do governo brasileiro de reinserir o planejamento de longo prazo nas políticas públicas. Nesse esforço, destaca-se a série de estudos e publicações que compuseram o projeto Perspectivas do Desenvolvimento Brasileiro, formulado pelo Instituto de Pesquisa Econômica Aplicada (Ipea) no início de 2008 (Ipea, 2009).

Brasil Saúde Amanhã: população, economia e gestão se insere neste conjunto de obras que pretende refletir sobre o país que queremos em um horizonte de vinte anos. Seu objetivo é expressão de um desejo de realidade, na concepção de previsão formulada por Gramsci (2000: 343):

É certo que prever significa somente ver bem o presente e o passado enquanto movimento: ver bem, isto é, identificar com exatidão os elementos fundamentais e permanentes no processo. No entanto, é absurdo pensar numa previsão puramente "objetiva". Quem faz previsão tem, na realidade, um "programa" que deve ser levado ao triunfo; e a previsão é, exatamente, um elemento desse triunfo. (...) somente na medida em que o aspecto objetivo da previsão é ligado a um programa, este adquire objetividade:

1. porque somente a paixão aguça o intelecto e ajuda a tornar mais clara a intuição;

2. porque, sendo a realidade a aplicação da vontade humana à sociedade das coisas, prescindir de qualquer elemento voluntário ou calcular somente a vontade dos outros como elemento objetivo do jogo geral mutila a própria realidade.

Ao contextualizar aspectos da demarcação macropolítica e macroeconômica do Brasil atual, como base das projeções de desenvolvimento econômico e social para as próximas duas décadas, procura-se compreender a saúde como um processo social - e não apenas como fruto do conhecimento biomédico, dependente da prestação de serviços de caráter setorial. Ao contrário, conquistar 
melhorias consistentes para a saúde pública e reduzir as iniquidades exige intervenções diretas sobre os amplos aspectos que moldam as condições de vida e saúde da população.

Com tal enfoque, este livro integra um conjunto de publicações resultantes de estudos realizados pela iniciativa Brasil Saúde Amanhã uma rede multidisciplinar de pesquisa, organizada e coordenada pela Fundação Oswaldo Cruz (Fiocruz), que investiga e propõe caminhos para o país e para o setor Saúde no horizonte temporal de vinte anos. Tem sido relevante o apoio do Departamento de Monitoramento e Avaliação do Sistema Único de Saúde, da Secretaria Executiva do Ministério da Saúde (Demas/SE/MS), com recursos do Fundo Nacional de Saúde do Ministério da Saúde para o desenvolvimento dos trabalhos.

Apoiada em um forte componente de pesquisa e no claro compromisso com a efetivação do Sistema Único de Saúde (SUS) e a melhoria da saúde pública brasileira, a iniciativa integra diferentes perspectivas: desenvolvimento e saúde, condicionantes econômicos e sociais da saúde, população e saúde, organização do sistema de saúde, financiamento setorial e complexo econômico-industrial da saúde (CEIS).

A primeira fase da iniciativa gerou a publicação do livro A Saúde no Brasil em 2030: diretrizes para a prospecção estratégica do sistema de saúde brasileiro, em 2012. A obra somou esforços da Fiocruz, da SAE, do Ipea e do Ministério da Saúde (Fiocruz, 2012). Posteriormente a íntegra dos estudos foi publicada em cinco volumes em 2013 (Fiocruz, 2013).

Prospectar o futuro é ter um programa de ação. É criar elementos para a articulação e indução de políticas econômicas e sociais, no interesse do desenvolvimento com equidade, fomentando o acesso e a inclusão de camadas excluídas, expandindo e assegurando direitos sociais às significativas parcelas da população que permanecem marginalizadas.

Os autores e organizadores deste volume consideram que o setor Saúde tem um papel preponderante neste desafio, ao influir decisivamente no modelo de desenvolvimento do país. Por isso, a prospecção estratégica dos cenários futuros do sistema de saúde é tão necessária para acompanhar e transformar tendências, indicadores e realidades.

No entanto, no campo social, os possíveis movimentos (mudanças, alterações) são apenas tendências, mais ou menos intensas, produto da ação de agentes (atores) sociais, e, por essa razão, os resultados esperados (projetados) são meramente possibilidades que podem concretizar-se ou não em decorrência de fatores pouco conhecidos. A incerteza no campo social é uma função inversa do tempo transcorrido entre a formulação da prospecção e o momento da observação.

De outro modo, o alto nível de formalização da prospecção, enquanto projeção, é possível na área da demografia, em que os movimentos observáveis têm uma considerável inércia a curto e médio prazos, ainda que pontualmente possam sofrer alterações mais ou menos súbitas de difícil previsão.

A visão estratégica integra as perspectivas, procedimentos e ferramentas, tanto de análise de tendências quanto de rastreamento de horizontes. Segundo Habegger (2010: 50), 
A visão estratégica pode ser definida como uma tentativa deliberada para ampliar os "limites de percepção" e para expandir a consciência das questões e situações emergentes. Destina-se a apoiar o pensamento estratégico e a tomada de decisão, desenvolvendo uma gama de formas viáveis de como o futuro poderia se desdobrar.

Este livro trata da demarcação macropolítica e macroeconômica do Brasil atual, base das projeções de desenvolvimento econômico, social e da saúde para as próximas duas décadas.

A frase de Wanderley Guilherme dos Santos - "se a realidade constrange, as aspirações libertam" - sugere, com base em suas reflexões, a possiblidade de definir cenários mais otimistas e menos conservadores para a evolução política do país, replicados nos demais capítulos, referentes à evolução da economia e do sistema público e universal de saúde no Brasil até 2035.

O trabalho desse autor - "Brasil amanhã: cenários políticos" -, que abre o livro, assinala que as dinâmicas de crescimento populacional, de urbanização e de organização do mundo do trabalho verificadas no Brasil contemporâneo projetam, para 2035, a consolidação de um único colégio eleitoral, nem amorfo nem homogêneo em suas preferências, integrado por toda a população brasileira, urbana e rural. A partir das precisões de crescimento populacional e da taxa de urbanização, bem como dos números brutos de sindicalizados e voluntariamente organizados verificados no presente, a participação política não se limitará à política parlamentar, requerendo a consideração de novas configurações institucionais.

Para apoiar essa afirmação, Wanderley Guilherme dos Santos toma como ponto de partida a infraestrutura humana da atividade política, centrada em dados da dinâmica populacional e urbana, destacando, na última metade do século passado, não só o crescimento populacional mas também a rapidez da urbanização do Brasil. O impacto dessa dinâmica se traduzirá, entre outros aspectos, em diferenças na mobilização eleitoral. As demandas dirigidas às instituições políticas, além da pauta vigente, de direitos civis, políticos, econômicos e sociais e do embate associado a decisões alocativas, serão tipicamente voltadas para os temas urbanos, que ocuparão a agenda política em caráter urgente e conflitivo.

O autor acentua que tais conflitos devem-se, desde logo, à grande desigualdade econômica e social no país, assinalando as características peculiares da organização do mundo do trabalho no Brasil, pela qual grande parte da titularidade dos direitos pertencia e pertence à ocupação e não à pessoa, pela associação de direitos sociais a rubricas ocupacionais, inicialmente vinculadas a sindicatos.

Destaca também, no Brasil de hoje, a presença de novas organizações de representação de interesses mais específicos ligados às políticas públicas e sociais e a temas no campo da ação coletiva, que vem se somando à representação sindical do mundo do trabalho formal. Sua simples existência explica o potencial de agravamento de conflitos ou tensões que permeiam a sociedade.

Nesse contexto, Wanderley Guilherme dos Santos assinala que, em termos redistributivos, existem dois cenários principais para a evolução política do país. Em um deles, seria possível subtrair multidões à situação de miséria sem que se modifique a taxa de desigualdade na distribuição agregada de bens e valores, mantidos os conflitos e competições vigentes na sociedade brasileira e entre a sociedade e o poder político. 
Entretanto, conforme o autor, não parece haver obstáculos intransponíveis a outro cenário, no qual a redistribuição atenderia em geral as aspirações da população e, em escala superior, os grupos miseráveis e pobres, como vem acontecendo na última década. Este cenário otimista se baseia no fato de que o Brasil já dispõe de graus de autonomia interna para decidir, democraticamente, sobre as políticas que melhor reflitam a razão aspirações/realidade. Sua materialização depende também, inegavelmente, das projeções macroeconômicas para o período. Quanto mais dinâmica a economia, mais rapidamente se dará o acesso a direitos materiais.

No segundo capítulo, "Dinâmica demográfica e distribuição espacial da população: o acesso aos serviços de saúde”, Antônio Tadeu Ribeiro de Oliveira e Maria Monica Vieira Caetano O’Neill analisam a dinâmica demográfica no país, cujo conhecimento é fundamental para compreender os impactos na transição epidemiológica e no acesso aos equipamentos e serviços de saúde. São intensas as transformações vividas pelo país no campo da demografia: a acentuada redução dos níveis da fecundidade; o envelhecimento populacional, reflexo do aumento da esperança de vida ao nascer, entre outros fatores; e as mudanças nos fluxos migratórios, direcionados às cidades médias e com reduzida proporção no deslocamento para as grandes metrópoles.

Tendo traçado projeções e cenários para a transição demográfica brasileira, os quais foram publicados no livro A Saúde do Brasil em 2030: diretrizes para a prospecção estratégica do sistema de saúde brasileiro (Oliveira \& O’Neill), os autores consideram neste capítulo as transformações regionais, analisando a fecundidade, a razão de dependência total, a de idosos, o índice de envelhecimento, os indicadores relativos à mortalidade e a mobilidade espacial interestadual da população.

Espera-se que em um cenário prospectivo favorável, os indicadores apresentem níveis semelhantes aos observados nos países desenvolvidos - estas são as tendências observadas para a taxa de fecundidade total, o envelhecimento populacional, a esperança de vida ao nascer e a taxa de mortalidade infantil. Embora se constate uma diminuição das distâncias, o Brasil setentrional permanecerá defasado em relação às regiões Sul e Sudeste, que alcançarão as taxas observadas nos países centrais antes de 2030.

No tocante à mobilidade espacial da população, projeta-se a redução da atratividade migratória exercida pelo estado de São Paulo, embora se mantenha como principal polo de atração; o aumento da retenção de população na região Nordeste; a migração de retorno; os novos eixos de deslocamentos populacionais em direção às cidades médias no interior e nas periferias metropolitanas. Quanto aos movimentos migratórios internacionais, há um maior grau de incerteza, a depender do comportamento da economia mundial. É importante destacar que os dados do Censo Demográfico de 2010 registraram não só o aumento no retorno de brasileiros, que representou a maior parcela das entradas vindas do exterior, como o acréscimo da chegada de estrangeiros.

Os autores estudaram, ainda, a centralidade em saúde identificada mediante associação de dois indicadores: o de complexidade nos centros localizados nas áreas imediatas de articulação urbanoregional e o de tamanho do setor, avaliado pelo volume das internações hospitalares. Num conjunto de 5.567 municípios analisados, 1.132 não possuem centralidade (não registraram a presença de equipamentos e especialidades, assim como internações hospitalares); apenas um, São Paulo, apre- 
senta centralidade máxima, igual a 1; e 3.997 foram classificados com a mais baixa centralidade, que corresponde à centralidade 6 (centros de menor porte e baixa complexidade). Esses resultados indicam uma configuração espacial desigual, beneficiando, de forma diferenciada, grupos sociais e lugares, e poderão orientar o planejamento sob a ótica territorial, permitindo direcionar a localização de investimentos e serviços, assim como possibilitar maior acesso da população aos serviços.

No capítulo seguinte, "Gestão pública no Brasil do século XXI: tendências reformistas e o desafio da profissionalização", Ricardo Carneiro e Flávia de Paula Duque Brasil examinam as reformas na gestão pública do Brasil no período contemporâneo, destacando as principais tendências reformistas que se desenrolam no século XXI. Consideram-se três eixos principais: a desconcentração administrativa e o hibridismo advindo dos novos arranjos organizacionais; a descentralização político-administrativa e a crescente saliência dos governos locais; e a governança democrática, colocando em relevo as instituições participativas. Para finalizar, discutem as questões relativas à profissionalização da administração pública brasileira.

Ao analisar as reformas na gestão pública, os autores buscam situar as transformações ocorridas como uma dimensão dos movimentos de reforma do Estado. Consideram as reformas ilustradas pelo modelo burocrático weberiano e pelo reformismo da New Public Management (NPM), comparandoas com aquelas processadas no plano internacional.

Embora a análise empreendida não tenha se dedicado explicitamente à discussão sobre as mudanças ocorridas nas funções desempenhadas pelo Estado brasileiro, são evidenciadas três grandes questões: o alargamento da prestação de serviços na área social, impulsionado, principalmente, pela definição de direitos sociais universalizados, no âmbito da Constituição Federal de 1988; a percepção de que o Estado tem um papel importante na promoção do desenvolvimento econômico e social, que não pode ser simplesmente delegada ao mercado; e a ampliação das funções de natureza regulatória.

Quanto às transformações na estrutura organizacional do setor público e seus mecanismos de atuação, a análise colocou em relevo três processos principais. O primeiro deles refere-se ao movimento de desconcentração, com a delegação da execução de um conjunto diversificado de serviços públicos, inscritos no rol de atividades não exclusivas do Estado, a organizações da sociedade civil ou da iniciativa privada. Dele resultaram novos arranjos organizacionais, tipificados pelas organizações sociais (OSs), organizações da sociedade civil de interesse público (Oscips) e parcerias público-privadas (PPPs), que se vêm somar às modalidades de terceirização, e às parcerias convencionalmente adotadas pela administração pública brasileira. Essas transformações tiveram grande impacto no setor Saúde, principalmente quanto à delegação para as Oscips da gestão de equipamentos de saúde, como tem ocorrido no estado de São Paulo. O segundo processo diz respeito à descentralização intergovernamental, com a crescente assunção da execução da prestação de serviços na área social pelos governos locais. O processo é comandado e induzido pelo governo federal, cabendo aos governos estaduais, grosso modo, uma atuação complementar e subsidiária à dos governos locais. Esse processo marcou profundamente a atuação do setor Saúde, através da chamada municipalização da gestão e prestação de serviços de saúde. O terceiro abrange as iniciativas de aprofundamento democrático no 
desenvolvimento das atividades de governo, da qual emerge uma pluralidade de instituições participativas, notadamente na esfera local de governo, que tem viabilizado o envolvimento da sociedade na implementação das políticas públicas e na avaliação de sua execução.

Esses processos de reforma e de transformação do Estado exigem a construção de burocracias competentes como condição primária e indispensável para ampliar a capacidade de atuação do Estado, decorrente das novas formas de coordenação, integração e controle das atividades do setor público. Para isso, se faz necessário mobilizar valores arraigados na sociedade, de modo a construir uma carreira sólida e digna para os servidores públicos em todos os níveis de governo.

As ponderações feitas pelos autores são de grande importância, levando-se em conta os reflexos na área da saúde, e geram algumas indagações. Como ter uma carreira de funcionalismo em saúde considerando três níveis de governo que atuam na gestão e prestação de serviços de saúde? Como elaborar plano de cargos, carreira e salários adequado às especificidades do setor Saúde, considerando que a carreira da burocracia estatal é única para os vários setores de governo?

Salvador Werneck Vianna e Maria Lucia Werneck Vianna, em "Qual padrão de desenvolvimento? Cenários macroeconômicos a longo prazo?”, analisam a construção dos cenários econômicos prospectivos para o Brasil nas próximas duas décadas. Na perspectiva de utilização de estudos prospectivos e construção de cenários como ferramentas para o planejamento, e não como exercício de futurologia, o ponto de partida é a definição dos cenários - ou, mais precisamente, do cenário otimista, a partir do qual foi estabelecida a trajetória que a economia brasileira deve percorrer para alcançá-los, em termos de decisões de política econômica e de fatos estruturais impactantes.

Os autores frisam a necessidade de mecanismos de acompanhamento e monitoramento, como instrumentos indispensáveis para o bom uso das técnicas de estudos prospectivos e a construção de cenários. Dada a metodologia adotada no estudo (que parte do cenário para a trajetória), sugerem que o acompanhamento do desempenho das variáveis é de grande relevância.

Lembram que, em grande parte da última década, a política econômica reafirmou o compromisso prioritário com a estabilidade de preços, em detrimento de objetivos relacionados ao crescimento da renda e do emprego. A política monetária constituiu-se no instrumento-chave para esse compromisso, cabendo às políticas cambial e fiscal funções meramente coadjuvantes. Apesar disso, o crescimento foi mantido, a partir de uma combinação de estímulos ao consumo e de políticas sociais inclusivas e redistributivas, e condições externas inicialmente favoráveis, embora tenham sofrido desaceleração no período recente.

De acordo com estimativas realizadas pelos autores, um aumento do Produto Interno Bruto (PIB) a taxas entre 3 e $4 \%$ a. a. - intervalo em que se situa a média verificada nos últimos dez anos, de 3,5\% - implicaria crescimento vigoroso do nível de atividade econômica (vis-à-vis a atual conjuntura). Nesse cenário ocorreria um enfrentamento virtuoso dos obstáculos e restrições decorrentes da crise internacional, bem como seria possível introduzir correções na implementação dos instrumentos de política econômica. A inflação poderia vir a ser controlada não apenas pelos instrumentos convencionais de política monetária, mas por políticas adequadas à consolidação das tendências de crescimento da economia. 
No que concerne às possibilidades do país de ingressar num ciclo longo de crescimento sustentado, sem gerar pressões inflacionárias ou sobre o balanço de pagamentos, e com base na evidência empírica brasileira, lembram que o crescimento continuado a taxas próximas de $5 \%$ ao ano requer uma taxa de investimento (formação bruta de capital em relação ao PIB) em torno de 25\% do PIB, hoje longe de ser alcançada. Os autores assinalam que o grande desafio para o desenvolvimento brasileiro é a expansão significativa do investimento em três setores estratégicos: infraestrutura urbana e logística, energia e indústria de transformação. Nesse processo, assumem a liderança do Estado como imprescindível, em particular nos dois primeiros setores.

Em termos da prospecção de uma redistribuição de renda virtuosa, destaca-se a possibilidade real de alteração da relação capital trabalho no PIB, com a elevação da participação dos rendimentos do trabalho alcançando 50\% do PIB para o período analisado. Os níveis de emprego e taxas de desemprego apresentariam resultados favoráveis em 2035 - com aumento substancial do emprego no segmento de trabalhadores com carteira assinada - e redução significativa do segundo indicador. Nesse contexto mais otimista, o coeficiente de Gini, utilizado como indicador da desigualdade chegaria a 0,40, situando-se então o Brasil em patamar mais favorável, relativamente ao conjunto da América Latina, mais próximo aos países desenvolvidos.

O crescimento econômico mais elevado com melhoria dos padrões socioeconômicos do país propiciaria a ampliação concomitante do espaço fiscal para investimentos de ampliação da cobertura e qualidade do sistema público de saúde, um salto no ensino público e melhorias em infraestrutura urbana.

Sulamis Dain e Kleber Pacheco de Castro, em "Alternativas para o financiamento da saúde pela União: espaço fiscal e oportunidades para as próximas duas décadas", descrevem o esforço ingente e as frustrações recorrentes na luta pela garantia de mais recursos para a saúde pública brasileira para garantir as determinações da Constituição Federal de 1988, no que se refere à universalização do direito material à saúde.

Examinam várias possibilidades de crescimento da receita pública associadas, por exemplo, ao aproveitamento de novas fontes, como royalties e outras compensações do petróleo, para concluir que as perspectivas de ganho de recursos não seriam suficientes para suprir as carências históricas da área, servindo apenas para mitigá-las.

Também avaliam as alternativas de reforma tributária, na perspectiva da garantia de recursos e dos critérios federativos de alocação de receita, por ela eventualmente transformados. Concluem os autores que a insuficiência do financiamento não está associada à ausência de espaço fiscal, e sim às prioridades que determinam o conjunto de decisões alocativas do governo federal, das quais a saúde tem sido alijada.

Isto se observa, em primeiro lugar, pela persistência da regra de vinculação da evolução dos gastos federais em saúde ao PIB nominal, menos favorável que a vinculação pretendida à receita tributária da União, oriunda de impostos e contribuições. Em segundo lugar, pelo sacrifício de receita tributária e da seguridade social ao setor privado, sob forma de renúncia de arrecadação, muitas vezes direcionada ao próprio segmento privado de serviços de saúde, em detrimento da saúde pública e universal. 
Assim, sugere-se que o financiamento do sistema público de saúde não depende apenas de propostas de novas fontes de recursos ou de mudanças institucionais no campo tributário, examinadas em detalhe, mas também e essencialmente da capacidade de gasto e das decisões alocativas do governo federal. Em tese, a simples situação de maior aporte de receita e menor necessidade de gastos em outras funções já seria suficiente para o poder público ampliar seu dispêndio em saúde.

A perda de capacidade do governo em fazer frente aos seus compromissos, ou a redução do espaço fiscal do setor público, apontada no capítulo de Sulamis Dain e Kleber Pacheco de Castro, têm relação direta com as desonerações tributárias promovidas em favor do setor privado. Tal tema torna-se especialmente relevante após a ênfase neste tipo de política nos últimos anos pelo governo federal, como parte integrante de sua agenda de incentivos de curto prazo ao crescimento econômico.

De fato, a evidência trazida pelos autores assinala que boa parte da resposta do governo central à crise internacional dos últimos anos se localizou na renúncia fiscal. Exemplos mais comuns foram a redução do Imposto sobre Produtos Industrializados (IPI) para automóveis, a desoneração da folha de pagamentos (previdência) e a redução do Imposto de Renda sobre a participação em lucros e rendimentos. Houve ainda renúncias com o objetivo explícito de controle inflacionário, como foi a desoneração da cesta básica e a redução tributação sobre combustíveis.

A recente redução do espaço fiscal do setor público tem relação direta com as desonerações tributárias promovidas na folha de salário em favor do setor privado, especialmente relevante para o governo federal nos últimos anos, como item integrante de sua agenda de incentivo ao crescimento econômico. O desfinanciamento da previdência, resultante dessa iniciativa, afeta o financiamento da saúde, por conta da competição por recursos no orçamento da seguridade social.

Esse tipo de desoneração tem influência na magnitude do espaço fiscal e na capacidade de gasto do governo, e não deve ser confundida com a renúncia fiscal promovida especificamente na saúde. Ou seja, além dos gastos tributários já citados, que limitam o orçamento como um todo, deve-se atentar para os gastos tributários que favorecem a atuação do setor de saúde privado (planos de saúde, entidades filantrópicas, medicamentos etc.). A mensuração e observação das duas linhas de desoneração são muito importantes para uma melhor compreensão do efetivo espaço fiscal com que se depara a União atualmente.

Em contraposição a essa opção, demonstra-se o impacto dinâmico das políticas universais de saúde sobre o PIB e sobre a redução das desigualdades, sugerindo que, em projeções para o futuro, o impacto combinado das políticas econômicas e sociais de investimento possa produzir o melhor dos cenários na consolidação dos avanços projetados nos textos anteriores, sendo assim parte essencial da recomposição do crescimento econômico e da diminuição da desigualdade no Brasil.

Os autores afirmam que a expectativa de crescimento dos gastos com saúde - com a necessária elevação da participação dos gastos públicos na proporção do gasto total - é bastante plausível, não apenas devido às projeções de crescimento da economia e da carga tributária. As projeções indicam também um menor volume de endividamento, o que requereria um menor esforço fiscal por parte do governo (menos gastos com juros e encargos da dívida e menos necessidade de superávit primário). 
Isso, por si só, contribuiria significativamente para a existência de maior espaço no orçamento e, consequentemente, para maior volume de despesas na área. De todo modo, o melhor cenário para a saúde seria o que vincula a evolução do gasto federal em saúde à receita bruta da União, rompendo com sua atual vinculação à evolução do PIB.

Em um cenário ideal para a saúde pública no Brasil, os autores afirmam que seria necessário contar com um aumento significativo na participação do setor público em saúde - por exemplo, um crescimento de 50\% sobre a composição atual. Além de assegurar um maior fluxo de receitas, para que a saúde tenha de fato um impulso sustentado de crescimento, o gasto total do setor público em ações e serviços públicos de saúde (não apenas da União, mas dos demais entes federados) deveria ser efetivamente ampliado e repassado integralmente ao setor.

Sulamis Dain e Kleber Pacheco de Castro concluem que ainda há um longo caminho a percorrer para se alcançar um patamar razoável de gasto público em saúde no Brasil. O problema não está no patamar de gasto total do Brasil, estimado em 9\% do PIB (WHO, 2013), o que não é pouco, em termos internacionais. Entretanto, seria necessário inverter a atual participação pública e privada no gasto de saúde (respectivamente $47 \%$ e $53 \%$ do gasto total), reforçando o gasto federal em suas funções de harmonização federativa e de correção das desigualdades em saúde em âmbito nacional.

Para tanto seria necessário comprometer o espaço fiscal com prioridades no campo das políticas sociais, notadamente as políticas universais de saúde e educação, relegadas até aqui a um segundo plano, vis-à-vis as políticas sociais associadas a clientelas específicas, como o Bolsa Família, e a direitos individuais de natureza previdenciária. Sem negá-las e, ressaltando sua importância, as demandas sociais, assinaladas na projeção política para o Brasil, tenderão a colocar, para o futuro, a obrigação de produzir resultados favoráveis nas políticas universais, combinando direitos individuais e coletivos em patamar resolutivo único e abrangente.

Um tema de grande relevância suscitado pela projeção de futuros possíveis para a política pública de saúde no Brasil refere-se à divisão de trabalho entre a esfera pública e a privada no campo da saúde, assim como à estrutura de financiamento e as formas de remuneração das empresas privadas prestadoras de serviços no setor. As modificações nos sistemas de saúde afetam os padrões de concorrência setoriais, e este fenômeno pode ser facilmente percebido a partir das ondas de fusões, aquisições e mudanças nas estratégias das grandes empresas que se seguem às mudanças na legislação que regula os sistemas públicos de saúde. Além disso, o setor geralmente se caracteriza pela existência concomitante de empresas não lucrativas.

No que tange à estrutura de demanda por serviços de saúde, algumas características são particularmente importantes para compreender a relação entre usuários dos sistemas de saúde e empresas. Do ponto de vista do usuário, tal demanda é marcada por uma forte assimetria de informação, entre o usuário e o especialista que prescreve o serviço, impondo ao serviço requisitado um caráter de necessidade, caracterizada pela baixa elasticidade-preço e, sobretudo, pela imprevisibilidade dessa demanda. Dada também a incerteza a respeito da utilização e custos desses serviços, é normal a interposição de agentes administradores do risco, como seguradoras, que, por estarem geralmente associadas a uma rede específica de fornecedoras de serviços, tendem a restringir a livre substituição entre elas. 
Nessa perspectiva, o capítulo de Célio Hiratuka, Marco Antonio Martins da Rocha e Fernando Sarti, "Mudanças recentes no setor privado de serviços de saúde no Brasil: internacionalização e financeirização" mostra que, para além da participação do setor privado no gasto em saúde e da natureza concorrente dos serviços prestados por este segmento de saúde suplementar, mudanças profundas, tanto no cenário mundial como no Brasil, vêm ampliando sua distância em relação à política de saúde pública no país.

O trabalho assinala que, desde a década de 1980, a gestão e a forma de operação internacional das grandes corporações vêm se transformando de maneira acentuada, como resultado das novas estratégias das corporações americanas. De um lado, elas são pressionadas pela competição acirrada levada a cabo por empresas da Europa Continental e do Japão. De outro, sofrem questionamentos acerca da eficiência do modelo gerencial da grande corporação multidivisional diversificada.

Acionistas mais ativos, remunerações atreladas ao desempenho das ações e o movimento de fusões e aquisições hostis seriam as formas de disciplinar e implantar um novo modelo de gestão, mais alinhado com o interesse dos acionistas, nessas grandes corporações.

A maior internacionalização, aliada à terceirização internacional de parcela crescente das etapas produtivas, passou a ser uma estratégia importante que resultou em uma grande descentralização das atividades produtivas. Em contrapartida, as grandes empresas buscaram reforçar seus ativos intangíveis e adquirir concorrentes estratégicos por meio de um processo intenso de fusões e aquisições.

A elevação do poder de comando das grandes corporações dos países centrais sobre o valor gerado nas diferentes regiões foi potencializado, e o aumento do escopo global passou a ser um fator fundamental na luta competitiva, resultado das vantagens associadas à capacidade de diversificar riscos, de operar vários mercados e de explorar diferenciais de custos e vantagens de localização em diferentes regiões.

O diagnóstico feito no capítulo chama a atenção para a crescente internacionalização observada na economia mundial, acompanhada de um movimento intenso de reestruturação patrimonial com um processo expressivo de fusões e aquisições. Esse quadro resulta em um grau de centralização de capital sem precedentes em vários setores e atividades, com expansão recente para setores diretamente relacionados com a oferta de serviços básicos à população e, portanto, também mais sujeitos à regulação estatal, como educação e saúde.

As análises das transformações recentes ocorridas no setor de serviços de saúde no Brasil devem ter esse movimento como pano de fundo. Para entender sua dinâmica, devem-se considerar, portanto, os condicionantes colocados por essa tendência mais ampla de internacionalização mundial.

Com esse pano de fundo, os autores realizam uma avaliação das particularidades estruturais do setor, assim como uma análise detalhada das empresas líderes e de suas estratégias mundiais, antes de discutirem especificamente as transformações no setor de serviços de saúde no Brasil.

Destacam uma série de fatores que tornam a saúde, do ponto de vista da organização econômica, um setor repleto de particularidades, de difícil enquadramento nas normas convencionais de 
regulação dos mercados. São eles: a estrutura peculiar de demanda e oferta, o relacionamento do setor com o avanço tecnológico, o impacto do risco e da assimetria de informação sobre a organização do setor.

Em outros termos, poucas características do setor de saúde justificariam deixar sua regulação à mercê meramente das leis de mercado. Nos próximos anos, esse processo deve continuar a ter impactos importantes sobre a abrangência e a qualidade dos serviços privados prestados, exigindo crescente atenção dos órgãos reguladores e dos formuladores de políticas públicas de saúde.

O trabalho aponta para o cerne da problemática projetada para a relação público-privada, num país que prescreve, entre suas diretrizes constitucionais, a universalização da política de saúde. De fato, o cenário indica uma dinâmica de concorrência com forte caráter concentrador, e, em se tratando de saúde, a criação de poder de mercado frente ao consumidor é particularmente mais problemática do que o usual em outros mercados.

Os autores, em suas conclusões, assinalam a gravidade que assume essa projeção para o setor Saúde, responsável pelo fornecimento de algo que é constitucionalmente reconhecido como um direito subjetivo, compondo parte dos direitos de cidadania, ao mesmo tempo que as tendências apontadas no desenvolvimento do segmento de saúde privada no Brasil vêm transformando os serviços do setor em "mercadoria altamente geradora de valor" (Conill, 2008), com participação crescente no lucro setorial e no PIB.

Ressalte-se que nenhum dos capítulos tem a pretensão de harmonizar as tendências opostas entre o público e o privado aqui assinaladas, quer nas escolhas políticas, nas opções político-econômicas, ou na definição do espaço fiscal e das prioridades de gasto público.

Conhecer os cenários possíveis, entretanto, é essencial para informar a agenda pública e desenhar trajetórias de compatibilidade com as projeções positivas esboçadas. Tanto a existência de alternativas viáveis de priorização e alargamento do espaço das políticas públicas e sociais, particularizadas para a saúde, sugeridas nestes trabalhos, quanto a expectativa de progressiva redução das desigualdades que a elas se associa, constituem elementos decisivos para apresentar um cenário otimista como possibilidade real de futuro.

Assim, tomando a realidade atual como ponto de partida e a materialização das aspirações como ponto de chegada, torna-se possível projetar futuros favoráveis ao desenvolvimento econômico e social, dos quais faz parte um patamar mais elevado de gasto público em saúde, compatível com a universalização do acesso, há tanto anunciada. 


\section{Referências}

CONILL, E. M. Sistemas comparados de saúde. In: CAMPOS, G. W. de S. et al. (Orgs.). Tratado de Saúde Coletiva. São Paulo, Rio de Janeiro: Hucitec, Fiocruz, 2008.

FUNDAÇÃO OSWALDO CRUZ (FIOCRUZ). A Saúde no Brasil em 2030: diretrizes para a prospecção estratégica do sistema de saúde brasileiro. Rio de Janeiro: Fiocruz, Ipea, Ministério da Saúde, Secretaria de Assuntos Estratégicos da Presidência da República, 2012.

FUNDAÇÃO OSWALDO CRUZ (FIOCRUZ). A Saúde no Brasil em 2030: prospeç̧ão estratégica do sistema de saúde brasileiro - desenvolvimento, Estado e políticas de saúde [online]. Rio de Janeiro: Fiocruz, Ipea, Ministério da Saúde, Secretaria de Assuntos Estratégicos da Presidência da República, 2013. 5 v.

GRAMSCI, A. Breves notas sobre a política de Maquiavel. In: GRAMSCI, A. Cadernos do Cárcere. v. 3. Rio de Janeiro: Civilização Brasileira, 2000.

HABEGGER, B. Strategic foresight in public policy: reviewing the experiences of the UK, Singapore, and the Netherlands. Futures, 42: 49-58, 2010.

INSTITUTO DE PESQUISA ECONÔMICA APLICADA (IPEA). Desafios ao Desenvolvimento Brasileiro: contribuições do conselho de orientação do Ipea. Brasília: Ipea, 2009. v.1.

OLIVEIRA, A. T. R. \& ONEILL, M. M. V. C. Cenário sociodemográfico em 2022/2030 e distribuição territorial da população: uso e ocupação do solo. In: GADELHA, P.; CARVALHO, J. N. \& PEREIRA, T. R. (Orgs.). A Saúde do Brasil em 2030: diretrizes para a prospeç̧ão estratégica do sistema de saúde brasileiro. v. 1. Rio de Janeiro: Fiocruz; Ipea, Ministério da Saúde, Secretaria de Assuntos Estratégicos da Presidência da República, 2013.

WORLD HEALTH ORGANIZATION (WHO). World Health Statistics 2013 - Part III: global health indicators. Geneva: WHO, 2013. 


\title{
BRASIL AMANHÃ: CENÁRIOS POLÍTICOS
}

\author{
Wanderley Guilherme dos Santos
}

Em outros vinte anos, a partir deste 2016, espera-se que a democracia brasileira tenha consolidado suas instituições e absorvidas as realidades criadas por aceitável taxa média de crescimento econômico, urbanização estável e, eventualmente, um indicador próximo do negativo de crescimento populacional. Como predicado, uma sociedade democrática ou o é ou não o é, obedecendo ao princípio do terço excluído da lógica clássica. O princípio veta a atribuição de valores numéricos a estágios intermediários, costume pouco eficaz de analistas norte-americanos.

A presunção de um estado final invariante - a democracia - dificulta a construção de cenários por via da análise em cadeia. Resta, como método, o exame da extrapolação de tendências da sociedade atual, com o objetivo de identificar que extrapolações são legítimas e quais as consequências para a democracia brasileira de então.

Os fenômenos sociais se diferenciam dos naturais, entre outras características, por não obedecerem ao princípio de que às mesmas causas correspondem necessariamente os mesmos efeitos e por estarem sujeitos à histerese no processo de causalidade, isto é, ao fato de certas consequências de um fenômeno não se apresentarem imediatamente, mas se revelarem transitivamente em momentos futuros. Essas características obedecem a duas linhas de determinação: certas consequências de um fenômeno poderem se transformar em cocausa desse mesmo fenômeno. Por exemplo, o crescimento populacional se transforma, no tempo, de cocausa de si próprio, aumentando sua taxa de expansão, a outra vez cocausa de si próprio, reduzindo a taxa de fertilidade.

A outra linha de determinante refere-se às mutações qualitativas ao final de processos quantitativos redundantes. Conhecida nas teorias recentes da biologia molecular, é fenômeno recorrente nas sociedades de qualquer natureza: democrática ou autoritária. Demandas insatisfeitas que se transformam em revoltas é o mais conspícuo desses fenômenos, mas longe de ser o único, em que o dinamismo é dado, entre outras pressões, pela lógica da imitação. Eleições críticas, isto é, aquelas em que a maioria tradicional do eleitorado muda de lado, tal como ocorreu nas eleições presidenciais de 2002, refazendo a maioria que se repetia desde a eleição de Fernando Collor de Mello é outro exemplo.

Cabe, portanto, elaborar um cenário de como funcionaria a democracia brasileira, em vinte anos, considerando: 
1) crescimento populacional e relação eleitorado/população e seus efeitos sobre a competição partidária;

2) complexificação da sociedade, a saber, a multiplicação das associações voluntárias e seus mecanismos de superação dos problemas da lógica da ação coletiva (explicação posterior do problema);

3) estrutura partidária em representação proporcional ou distrital majoritária; consequências para a governabilidade e a representatividade;

4) resultados possíveis em face da constitucionalização do país, ou seja, a materialização dos direitos constitucionais independentemente do estágio de desenvolvimento da região. As regiões Norte e Centro-Oeste só foram incorporadas com eficácia à política nacional recentemente, e assim mesmo de forma restrita;

5) relações entre Executivo, Legislativo e Judiciário em uma democracia gigante e regionalmente desequilibrada;

6) aumento da relevância do país no cenário internacional, em particular na América do Sul, já que é proprietário das reservas de água e petróleo, além de outros recursos naturais escassos.

A incerteza irredutível dos fenômenos sociais em razão dos seus determinantes básicos, além da capacidade humana em inovar, dificulta a construção de cenários plausíveis para além da aposta de que ocorrerá solidificação ou momentos de crise nas instituições democráticas, mas não retrocesso. Em tempos autoritários, a incerteza torna o processo político relativamente opaco. Finalizando, não é impossível imaginar a interveniência de alguns fatores que tornariam possível uma crise do sistema.

A esta introdução seguem-se considerações sobre crescimento populacional e relação eleitorado e população, complexificação da sociedade e reflexões sobre os cenários de futuro.

\section{Crescimento Populacional e Relação Eleitorado/População e seus Efeitos Sobre a Competição Partidária}

Em 2035 o Brasil terá aproximadamente 230 milhões de habitantes. Esta é a projeção atual do Instituto Brasileiro de Geografia e Estatística (IBGE). Por seu tamanho e história recente seria ousado, mas não temerário, antecipar a descrição de um país altamente urbanizado, industrializado, solidamente democrático e no qual as funções de governo estariam extensamente descentralizadas, tanto territorialmente quanto na formulação de políticas específicas. Mas a história humana não se revela como um processo inercial. Biologicamente, com certeza, não, e o resultado das interações sociais comprova a limitação das apostas nas quais o país do futuro venha a ser a projeção serial dos predicados do presente. E, todavia, este é o método implícito em ponderável número de análises sobre o futuro próximo e não tão próximo do Brasil.

É cautelar, portanto, em análises prospectivas, que se procure esclarecer quais seriam as consequências da interação de processos necessariamente concomitantes, embora com linhas de causalidade relativamente independentes. Por exemplo, as taxas de crescimento populacional contribuem 
de algum modo para a velocidade da distribuição dos habitantes por local de residência, urbana e rural. Mas o ritmo da urbanização, por seu turno, também obedece à estrutura da oferta de empregos, entre outras variáveis que explicam o que a literatura sociológica denomina de mobilidade horizontal. Retroativamente, é fato conhecido que a urbanização associada ao tipo de ocupação tende a alterar a taxa de fertilidade da população. Projetar para períodos longos a velocidade por assim dizer instantânea que os dois processos revelam na atualidade constitui caminho seguro para enorme desacerto. O cuidado ao projetar estados futuros da sociedade e da política exige atenção ao resultado da influência recíproca entre mais de duas variáveis, do que se presume venha a ser o estágio de cada uma delas.

A atividade da política é causa latente de modificações em praticamente todos os vetores que condicionam a ela própria, embora com eficácia e extensão diferenciadas. Isto significa que entre as variáveis relevantes para a análise política algumas podem ser classificadas como dependentes, outras como parâmetros, vista a lentidão de sua mudança. Concretamente, para exemplificar, o crescimento populacional é, em certa medida, afetado pelas políticas de saúde pública, entre outras, mas o resultado agregado do impacto requer uma década ou mais para ser significativo. Exemplo mais dramático, ainda no terreno da interface da população e do Estado de bem-estar social, encontra-se nas taxas de mortalidade infantil, sabidamente resistentes a decréscimos súbitos. Construir cenários para o futuro da atividade política, portanto, requer considerações sobre o hiato temporal em que opera seu sistema, por assim dizer, interno e externo de causalidade.

A infraestrutura humana da atividade política concentra-se, fundamentalmente, no número de seus habitantes e na ordem de grandeza de sua urbanização. O elevado dinamismo do crescimento populacional brasileiro, e sua provável evolução, já foram objeto de inúmeras investigações e, para efeito do presente cenário, o número provisório do IBGE será aceito como referência para o ano de 2030. Supõe-se que eventuais discrepâncias em relação ao número real, tanto para 2030 quanto para 2035, não comprometeriam o essencial do cenário completo.

Tão ou mais impressionante que o crescimento populacional, desde a segunda metade do século passado, foi a rapidez da urbanização do país. Tendo aumentado em apenas cinco pontos percentuais entre 1940 e 1950, passando de 31\% para 36\% a proporção de sua população que vive em áreas urbanas, aumentou essa proporção em nove pontos percentuais na década seguinte (45\% em 1960), em 11 pontos na década subsequente (56\% em 1970), mais 12 pontos em 1980 (68\% da população já era urbana). A partir de então, reduziu-se, como é natural, a velocidade do processo, mas ainda suficiente para fazer com que a taxa de urbanização brasileira alcançasse 84\%, em 2010, a três pontos percentuais acima dos $81 \%$ do Censo de 2000. Esse número coloca o Brasil na $27^{a}$ posição da estratificação mundial correspondente, à frente dos Estados Unidos (35ª - 82\% urbana em 2011), por exemplo, para não mencionar a China (51\% em 2012). Provavelmente nem toda a população de todos os países irá deslocar-se para áreas urbanas, sendo plausível que os critérios de classificação substituam o número de habitantes por tipo de atividade principal ou outro indicador.

De todo modo, supondo-se, conservadoramente, que, em 2030, a população urbana brasileira estará estacionada em $84 \%$ da população total, as instituições políticas deverão acomodar, naquela 
oportunidade, as demandas por serviços típicos das cidades com origem em cerca de 193 milhões e 200 mil moradores urbanos. Isto equivale a ter, só nas cidades, toda a população atual, acrescida de uns 3 milhões adicionais, pois o Censo de 2010 estabeleceu em 190 milhões e 733 mil (arredondados) o total da população brasileira (IBGE, 2010). O futuro da pauta de temas urbanos a ocupar a agenda política, como é de praxe, tende a permanecer urgente e rico de conflitos. Países sem problemas urbanos potencialmente explosivos, a saber, emprego, saúde, educação, segurança, criminalidade de toda sorte, mobilidade e, sim, lazer, são aqueles países de elevada renda per capita, sem dúvida, mas, necessariamente, com reduzida população total e, em particular, com modesta população urbana, embora de proporções maiúsculas em relação à total.

Ainda que os governos promovam políticas de controle populacional e de retenção da força de trabalho no campo, os números brutos que se apresentam a curto e médio prazo das grandes nações e vinte ou trinta anos não contam gravemente na contabilidade cronológica normal dos países - são para impressionar. Especialmente se tais políticas são decididas e levadas a efeito democraticamente. $\mathrm{Na}$ eventualidade de as políticas serem efetivadas por coação, o saldo de crescimento populacional e de urbanização permanecerá bastante elevado, não sendo razoável, além disso, esperar-se que políticas apoiadas em coação resistam por longos períodos.

Os processos de crescimento populacional e de urbanização seguiram em ambiente de total liberdade de escolha pessoal e familiar, no Brasil, mesmo nos períodos em que a política esteve submetida a constrangimentos ditatoriais. Tanto no período de 1937 a 1945 quanto no de 1964 a 1985, não foram estipuladas autoritariamente nem disseminadas à força quaisquer políticas destinadas a impedir a reprodução das famílias conforme o desejo delas ou a acorrentar os rurícolas a seus locais de nascimento. A curva histórica de ambos os processos obedeceu, no Brasil, ao perfil conhecido do que ocorreu em todos os países contemporâneos, isto é, após as iniciativas clínicas, descobertas laboratoriais e procedimentos sanitários para controle das causas de mortalidade, a partir de meados do século XIX, além da acentuada inserção de todos no comércio internacional. A repercussão da velocidade com que a transformação se operou no Brasil obrigou a alterações significativas no afazer político. São as consequências dessas características de infraestrutura que devem ser investigadas e projetadas.

Politicamente, o impacto imediato do crescimento populacional e da taxa de urbanização se revela na mobilização eleitoral. A obrigatoriedade constitucional do voto, desde 1945, não garantiu o cumprimento da exigência, dado o custo mínimo da abstenção eleitoral, por uma ou duas décadas. Havia uma reserva de potenciais eleitores não mobilizados, especialmente nas áreas do Norte, Nordeste e Centro-Oeste, que será rapidamente recrutada nas três décadas de 1960 a 1990.

Entre os acicates para o recrutamento encontrava-se, ironicamente, o peculiar regime brasileiro, desde o golpe de 1964, que associava um rodízio de ditadores militares à manutenção de eleições proporcionais regulares. Ao partido situacionista, Arena Renovadora Nacional (Arena), era vital manter a maioria nas assembleias legislativas dos estados, mas, fundamentalmente, na Câmara dos Deputados, em Brasília. Garroteada a federação, as assembleias estaduais perderam significação política maior, mas na Câmara dos Deputados a batalha era crucial. Perdê-la, obrigaria o governo a despir-se do véu com que disfarçava o despotismo e intervir abertamente no dia a dia político. Para 
a oposição, o Movimento Democrático Brasileiro (MDB), derrotar o governo nas urnas equivalia precisamente a desmoralizar a presunção de democracia, conquanto relativa, com que se apresentava ao país e em foros internacionais. A validação de vereditos contraditórios passou a depender do resultado das urnas, e os políticos brasileiros, pouco sensibilizados até então pelo baixo percentual do eleitorado, comparado à sua população adulta (ainda que descontada a taxa de analfabetismo), moveram-se impetuosamente em direção ao enorme contingente de latentes eleitores.

O resultado foi a inauguração de um processo de mega conversão eleitoral que nem mesmo a liberação do voto feminino proporcionou na Europa ou nos Estados Unidos, com destaque para as regiões secularmente entorpecidas. Na região Norte, a população cresceu 456\%, entre 1950 e 1991, enquanto o eleitorado aumentou em 1.426\%. No Nordeste, as taxas de crescimento foram, respectivamente, $136 \%$ e $655 \%$. No Centro-Oeste, outro dilúvio populacional com crescimento de $442 \%$, acompanhado de um maná de eleitores traduzido na proporção de $1.650 \%$ de aumento. Os números também são significativos nas regiões Sul e Sudeste. No Sul, a população cresceu, no mesmo período, $182 \%$ e o eleitorado $780 \%$. Finalmente, no Sudeste, os valores atingiram $178 \%$ no crescimento populacional e 649\% no tamanho do eleitorado. Conforme ainda os dados primários do IBGE e do Tribunal Superior Eleitoral, o agregado Brasil experimentou, entre 1950 e 1991, um crescimento populacional de $183 \%$ e uma expansão de $727 \%$ no seu eleitorado total.

Convém ilustrar a magnitude do fenômeno brasileiro com algumas comparações internacionais entre as décadas de 1970 e 1990. Conforme o manual político da Organização para a Cooperação e Desenvolvimento Econômico (OCDE), o crescimento eleitoral da Alemanha, de 70/80 e 80/90, foi, respectivamente, em porcentagens, 11,8 e 39,6; da França, na mesma ordem de décadas e valores, 18,9 e 6,6; da Itália, 18,6 e 8,0; do Reino Unido, 4,5 e 5,2; finalmente, os números dos Estados Unidos foram 30,5 e 15,2. Embora o aumento populacional nesses países tenha sido bastante inferior ao do Brasil, é significativamente superior a dos citados.

De se esperar, as taxas populacionais eleitorais perderam ímpeto nas duas décadas subsequentes, no Brasil, sem deixar de impactar com força no tamanho de sua população, de sua taxa de urbanização e de seu colégio eleitoral. Em 2002, de todas as anteriores áreas geográficas do país, somente o Norte apresentava um eleitorado correspondente a menos do que $60 \%$ de sua população total. Em 2006, todas as regiões já haviam ultrapassado essa marca e duas, Sul e Sudeste, atingido a dos 70\%. Em 2010, o eleitorado total brasileiro, de 135.000.604, alcançou a 71\% de sua população, que era, segundo o Censo, aproximadamente de 190 milhões habitantes. Se o cálculo fosse efetuado em relação à população adulta, o percentual se aproximaria dos $80 \%$. Tendo em vista o envelhecimento esperado da população - aumento da longevidade associado à reduzida taxa de crescimento populacional -, é prudente manter a perspectiva conservadora de que a taxa de eleitores permaneça mais ou menos constante em relação à população.

Um eleitorado equivalente a $71 \%$ da população estimada para 2035 alcançaria o valor de 163 milhões de eleitores, cerca de $20 \%$ a mais do que o eleitorado atual e de $14 \%$ a menos do que a população total do país, hoje. Conservadoramente, e em cenário livre de surpresa, é como se toda a população do Brasil contemporâneo, urbana e rural, fosse um único colégio eleitoral. Não o é, 
mas, de acordo com as projeções conservadoras do processo de urbanização antes realizadas, será esse o tamanho urbano do eleitorado brasileiro em 2035. E ele não é amorfo ou homogêneo em suas preferências como o número bruto, no qual cada um é semelhante ao próximo, poderia sugerir.

\section{A Complexificação da Sociedade}

Pondo entre parênteses a família e a escola, matrizes relevantes e primárias da formação cívica e política dos cidadãos, é a ocupação profissional que interfere de maneira profunda no amadurecimento de uma consciência, cuja gênese encontra-se nos laços de parentesco e na escolarização fundamental. Nos casos em que isso se dá, a influência da educação continua até o ciclo universitário. Mas é aqui, também, que, mesmo para esses bem educados, a ocupação que agora escolhem desempenhará igual papel decisivo.

As ocupações são o modo burocrático em que se apresenta o incessante processo da divisão social do trabalho. Ao contrário do crescimento populacional e da extensão da absorção urbanística, plurideterminados, mas relativamente previsíveis, a divisão social do trabalho é radicalmente aleatória. Fruto da especialização, tornou-se vertiginosa com a associação do conhecimento científico à produção material, via tecnologia, e, como a inovação nesta área, essencialmente imprevisível. Certo que a competição econômica pressiona a produtividade relativa do trabalho, isto é, a de obter mais produtos pelo mesmo tempo de esforço, mas o sucesso da empreitada depende da descoberta de novas formas de produção, majoritariamente dependentes de avanços tecnológicos. O investimento em tecnologia, variável vital da competição econômica capitalista, é provavelmente o de mais alto risco em todo o processo produtivo e, não obstante, inevitável. A conhecida cláusula de aversão ao risco para explicar eventual timidez do empresariado diante da incerteza do mercado deve ser complementada pela certeza do fracasso, em caso de fuga à competição tecnológica e, portanto, ao risco do investimento. A insistência no investimento não garante o sucesso, pois o progresso da divisão do trabalho é dependente do acaso bem mais do que da persistência. Mas, sem esta, nem mesmo o acaso pode beneficiar os tímidos.

Há métodos de aferição da extensão da divisão social do trabalho, todos, entretanto, sujeitos a controvérsias estatísticas e conceituais. É possível, contudo, formar uma imagem da extensão do processo verificando o quanto a realidade se afasta do ponto zero da especialização laboral. Em tese, os povos primitivos conhecem quase que apenas a divisão sexual do trabalho, reservando-se as tarefas mais pesadas e perigosas para os homens, ficando com as mulheres as tarefas, digamos assim, domésticas. Entre os homens e entre as mulheres, todavia, não haveria qualquer especialização exigindo aprendizagem específica e discriminante: caçar, pescar, construir habitação é conhecimento comum entre os homens da comunidade, tanto quanto cuidar de rebentos, cozinhar ou costurar é sabedoria universal entre as mulheres. E nem são surpreendentes os casos em que mulheres desempenhavam algumas das tarefas masculinas, e os homens, as de mulheres. O número de ocupações reconhecidas, portanto, embora sempre inferior ao número de ocupações existentes, serve como indicador primário, mas aceitável, da extensão alcançada pela especialização do trabalho. 
A métrica para o processo complica-se, no Brasil, pelos conceitos diferentes que agências distintas utilizam e, crucialmente, pelo hiato cuja magnitude é desconhecida entre as ocupações reais e as ocupações oficialmente reconhecidas. Por razões que remontam ao desdobrar-se da Revolução de 1930, o acesso dos empregados aos direitos do trabalho e da Previdência, então sendo criados, dependia do reconhecimento da ocupação pelo Ministério do Trabalho. Essa invenção institucional permitia ao governo, e dela se beneficiaram todos os governantes posteriores, até hoje, controlar o ingresso de fatias da população no universo dos cidadãos plenos. A titularidade dos direitos pertencia e pertence à ocupação, não à pessoa. Esta é a origem de uma das características da mobilização social no país: a busca pelo reconhecimento da profissão. Claro, em todos os países as ocupações terminam sendo formalizadas e licenciadas por agências públicas, mas a inovação brasileira consistiu na associação de direitos sociais a rubricas ocupacionais.

Com o transcurso do tempo e a complexidade crescente dos processos materiais de produção, a percepção da acelerada especialização do trabalho passou a variar, no mínimo, do sindicato da categoria profissional a associações privadas e destas ao cadastro oficial. Para efeito de grande agregação, por exemplo, o número de categorias econômicas em que a população foi classificada pelo IBGE, por décadas, foi o seguinte: 1950/1980: 10 categorias - 1991: 11 - 2000: 13. Segundo o portal Brasil Profissões, seria possível falar em 598 profissões regulamentadas, embora o Ministério do Trabalho e Emprego mencione apenas 68 entre um total de 2.422 ocupações reconhecidas e descritas. Com certeza no número oficial de profissões regulamentadas, embora recente, não devem constar as de juiz de futebol e de vaqueiro, objetos de legislação específica no segundo semestre de 2013.

A discrepância se deve, à agência ou perspectiva da contagem, à distinção entre trabalhadores com ocupação catalogada, mas sem carteira assinada, além de peculiaridades do processo de registro e mensuração da especialização. Todas as razões se somam para adicionar dificuldade à extrapolação de números atuais para cenários futuros, não fossem os imperativos da inovação tecnológica produtores de imprevisibilidade. A relevância dos números, de todo modo, se funda nas consequências que a divisão do trabalho produz na esfera política. E estas são, em maiúsculo, o número de sindicatos e sindicalizados e o número de associações chamadas de civis, porque não são de direito público.

Ao contrário do que supõem o senso comum e as discussões jornalísticas, a sociedade brasileira é altamente mobilizada, se vista pelo ângulo do número de instituições pelas das quais ela pode manifestar suas demandas e preferências. O exemplo da mobilidade histórica dos Estados Unidos não deve ser tomado como paradigmático, como ocorre, diante do qual todos os demais parecem mesquinhos. Contar com 10.167 sindicatos de trabalhadores e 4.840 sindicatos patronais, caso brasileiro, não é desprezível em nenhuma sociedade moderna. Os sindicatos de trabalhadores exibem 16 milhões de associados, praticamente três vezes toda a população da Noruega. Pode parecer um número modesto por não ultrapassarem a 17\% dos trabalhadores ocupados, mas, no caso, os números absolutos são mais importantes do que os porcentuais. ${ }^{1} \mathrm{~A}$ interferência sindical nas reivindicações não só salariais, entre outras, é notória e constante. É absolutamente rara, em períodos democráticos, a ocorrência de greves ou manifestações selvagens por parte dos trabalhadores. Designam-se por "selvagens"

\footnotetext{
1 Todos os dados brutos estão na Pesquisa Nacional por Amostra de Domicílios - Pnad (IBGE, 2011).
} 
os movimentos sociais aleatórios, não programados e sem direção institucionalizada. Ao contrário dessa definição, os sindicatos têm sido personagens e autores conscientes na elaboração do roteiro político nacional.

A outra fonte relevante para a dinâmica política se concentra no universo de associações voluntárias. No Brasil, a expressão "associações voluntárias" cataloga ações coletivas bem mais qualificadas do que a simples característica de não ser coercitivamente constituída. Este é um atributo necessário, naturalmente, e, em geral, suficiente para a matrícula de uma organização no universo dos pesquisadores e analistas. A pesquisa realizada em cooperação pelo IBGE e o Instituto de Pesquisas Econômica e Aplicada (Ipea), com a colaboração da Associação Brasileira de Organizações Não Governamentais (Abong), As Fundações Privadas e Associações sem Fins Lucrativos no Brasil - 2010 (IBGE, 2012), descreve tais entes com os seguintes atributos: 1) privados; 2) sem fins lucrativos; 3) legalmente constituídos; 4) capazes de gerenciar suas próprias atividades; 5) voluntários. A população de organizações assim qualificadas não é muito diferente do universo comum da literatura, como é possível perceber pela descrição das dez grandes categorias utilizadas na pesquisa para contagem das unidades. São entidades da pesquisa organizações que, atendendo os requisitos estabelecidos, estão envolvidas com os tópicos a seguir: habitação, saúde, cultura e recreação, educação e pesquisa, assistência social, religião, partidos políticos, sindicatos, associações patronais e profissionais, meio ambiente e proteção animal, desenvolvimento e defesa de direitos e, por fim, outras instituições privadas sem fins lucrativos. Cada uma dessas categorias cobre número variado de subitens, em um total de 25 escaninhos classificatórios.

O que torna esses números particularmente relevantes para a análise política é o reconhecimento de que se referem a associações de interesses não cobertos pelas organizações de trabalho ou ocupacionais legalmente reconhecidas, tais como os sindicatos. Elas se formam com objetivos ainda mais específicos do que os dos sindicatos, tendo em vista dialogar com o poder público, ou seja, com objetivos políticos. Ademais, são impulsionadas por uma urgência e constância que escapam à abrangência da representação sindical. Associações de pais de crianças vítimas da síndrome de Down, por exemplo, estão permanentemente em busca de atendimento para um ou outro problema. O mesmo ocorre com associações de bairros. Como não surgiram de parto natural, mas resultaram da arte de coordenar ações coletivas, elas precisam superar todo tipo de dificuldades, inclusive os custos de organização, para sobreviver. Embora nem todas sejam igualmente ativas ou eficazes ao mesmo tempo, sua simples existência remete ao potencial de conflitos ou tensões que permeiam a sociedade.

Aspecto nada trivial da rede organizacional das comunidades refere-se à sua disseminação espacial e representativa, incomparavelmente superior à dos sindicatos. Conforme a pesquisa citada, em 2010, as fundações privadas e associações sem fins lucrativos (200.700) correspondiam a 52,2\% do total de 556.800 de entidades sem fins lucrativos e a 5,2\% do total de 5,6 milhões de entidades públicas ou privadas, lucrativas e não lucrativas, que compunham o Cadastro Geral de Empresas do IBGE para aquele ano.

As organizações religiosas aparecem como o maior grupo na lista das dez categorias, concentrando $29 \%$ do total de entidades. Em segundo lugar, encontram-se as organizações patronais e profissionais, não sindicais, correspondendo a $15,5 \%$ do total; seguem-se as relativas a desenvolvimento 
e defesa de direitos, com 14, 7\%, e assistência social, com 10,5\% do total. Essas quatro categorias de organizações são responsáveis por 70\% de todo o universo recenseado. A distribuição regional, cada uma com sua ordem de grandezas no número de associações por categoria, e o número correspondente a cada subcategoria variam bastante. Também o período de aparecimento e a longevidade das organizações diferem, nacional e regionalmente. Para efeito da presente análise, contudo, vale a pena registrar, com as palavras do próprio documento oficial (IBGE, 2012), que essas organizações

são relativamente novas no Brasil; a maior parte delas (40,8\%) foi criada no período de 2001 a 2010. Das 118,6 mil entidades nascidas na década, a metade $(50,8 \%)$ surgiu nos últimos cinco anos, cerca de $4 \%$ a cada ano, evidenciando um crescimento regular no período. Interessante também observar o peso das entidades criadas no período de 1981 a 2000: elas representam $46,5 \%$ do total das entidades em atividade em 2010. A idade média das associações e fundações existentes é de 14,4 anos.

Uma informação especialmente relevante nesse contexto refere-se à participação relativa das diferentes categorias de associação e o período de criação. De quatro grandes categorias antes registradas, e mais a de meio ambiente e proteção animal, somente as religiosas (entre as quatro) e as de meio ambiente cresceram em participação relativa no total de associações, considerando-se dois períodos: o de 1991 a 2000 comparado ao de 2001 a 2010. A participação das associações religiosas passou de $24,4 \%$ no primeiro para $27,0 \%$, no segundo. As de assistência social, patronais e profissionais e de desenvolvimento e defesa de direitos tiveram reduzidas suas respectivas participações relativas no total de organizações. Já as de meio ambiente e proteção animal passaram de 0,7\% para $1,1 \%$, um crescimento de $57,1 \%$ entre os dois períodos.

O elevado nível de mobilização de interesses se verifica pelo número de instituições representativas deles (acima de 290 mil), mais de um múltiplo de dez, quando comparado ao número registrado de ocupações (cerca de 2 400). Só não é possível tomar esses números como diferentes medidas da especialização do trabalho porque, ao contrário dos sindicatos, apenas um por categoria ocupacional, as associações voluntárias, porque são de direito privado, admitem o convívio de mais de uma instituição por tipo de interesse. Não obstante, são seguros indicadores do burburinho social e político que caracteriza a sociedade brasileira atual.

Se, por hipótese, registrássemos uma econômica média de 30 pessoas por cada instituição, obteríamos uma mobilização aproximada de 8 milhões e 700 mil pessoas ativas em busca de satisfação de seus interesses. Algo pouco menor do que um Portugal inteiro mobilizado. Por certo, um país com a população prevista, a taxa de urbanização antecipada, mesmo conservadora, e os números brutos de sindicalizados e voluntariamente organizados verificados no presente, ainda que os últimos permanecessem como são hoje, não poderia conter toda sua participação nos limites da política parlamentar. Não se trata de problema a ser resolvido pelo número de partidos nem pelo aumento do tamanho do parlamento. O crescimento da instituição parlamentar traz a desvantagem de tornar cada membro do parlamento proporcionalmente menos representativo, seja qual for o número de partidos ou o sistema eleitoral. Três das quatro mais estáveis democracias ricas possuem parlamentos maiores do que o brasileiro (excluindo-se o Senado, quando existe). A Câmara dos Comuns, inglesa, conta com 650 membros, sua equivalente alemã com 650, a da França com 577 e a dos Estados Unidos com 435, 
a única menor do que a brasileira. E são regulares, naqueles três países, os debates com o objetico de que, eventualmente, se diminua o tamanho da instituição, matéria também vez por outra ventilada no Brasil. Em qualquer caso é pouco provável que o crescimento da participação política possa ser acomodado estritamente por uma elefantíase institucional da Câmara dos Deputados.

O que é certo de se prever é um debate sobre o tamanho das bancadas estaduais na Câmara dos Deputados em vista da participação relativa crescente do Centro-Oeste e do Norte, e alguns estados do Nordeste, como a Bahia, em face da relativa estabilidade do Sul e do Sudeste, sobretudo do Rio Grande do Sul, São Paulo e Rio de Janeiro. Com isso, a pauta do problema federalista, já agudo por razões tributárias, tende a ser acrescida pela reivindicação de reforma dos princípios da representação política. Bem entendido, esta reivindicação é distinta e bem mais genuína do que as costumeiras diatribes contra o sistema eleitoral e partidário. A questão federalista é, essencialmente, matéria constitucional implicando pactos políticos fundamentais.

Uma mobilização de interesses assentada em um país de elevada população e urbanização transborda automaticamente os limites da política representativa, se mantido constante o regime democrático, inaugurando formas de participação direta. Para 2030, o que é razoável prever, politicamente, em um cenário livre de surpresas, é um Brasil altamente dinâmico, sejam quais forem a lista de partidos políticos e o número de representantes no parlamento nacional. Em aparência, essa aposta parece quase trivial, posto que antecipa não mais do que um país praticamente semelhante ao atual, só que com números agregados de maior expressão. Ocorre que o tamanho interfere na qualidade da vida social e política, sobretudo em função do contexto em que surgem.

Com o crescimento do número de meios móveis de comunicação, os custos de obter e transmitir informações, ou seja, de organizar ações coletivas foram drasticamente reduzidos. Hoje, o número de domicílios que só utilizam telefones celulares nos aglomerados subnormais alcança 54\% do total. Como é sabido, o telefone celular permite a comunicação permanente e ambulatorial. A televisão está presente em $97 \%$ desses lares, dos quais, 20,2\% possuem computador com acesso à internet. A esses números devem ser acrescentados os que se irradiam das aglomerações normais, na classificação do IBGE. A menção às aglomerações subnormais justifica-se por indicar o limite inferior do consumo dos bens, o qual, como se percebe, tende a igualar o significado do mercado em ambos os tipos de aglomeração. Ademais, deve-se contar com a possibilidade de desaparecimento das aglomerações subnormais. O ritmo de seu crescimento arrefeceu, como o comprovam as investigações do IBGE, estimando que, entre 2000 e 2010, o número de aglomerações subnormais passou de 10.600 milhões para 11.400 milhões, não mais do que um acréscimo de 6,7\%.

Em face das políticas públicas em execução nas grandes metrópoles (segurança, saneamento e habitação), e agora também nas médias e pequenas, não é romantismo imaginar que em futuro não muito remoto, talvez em 2030, as diferenças entre o que agora se denomina de aglomerações subnormais desapareçam, e que a diferença básica em relação ao entorno delas se limite à diferença de renda per capita. Segundo pesquisa do Ipea divulgada na primeira semana de dezembro de 2013, as cinco maiores concentrações de habitantes dessas aglomerações se distribuíam da seguinte ordem: Salvador (607 mil), Recife (564 mil), São Paulo (409 mil), Belém (403 mil) e Rio de Janeiro 
(340 mil) (Ipea, 2013). São, sem dúvida, números lamentáveis, mas não paralisantes ou invencíveis. Provavelmente, no futuro aqui modelado essas populações já estarão vivendo em áreas antes decaídas, transformadas em bairros de baixa renda, com padrão de consumo, entretanto, bastante próximo ao padrão das de renda média em relação à significativa cesta de consumo. No mesmo sentido, estarão expostas à mesma facilidade de acesso a informações relevantes e também terão sensível redução dos custos de mobilização e da organização da ação coletiva.

A capacidade de mobilização instantânea e permanente provoca mudança no padrão de relacionamento entre o cidadão e o poder público. Para a política, manifestações como as de junho de 2013, sobretudo nas cidades do Rio de Janeiro e de São Paulo, impressionam no curto prazo, mas não são duráveis. Passado um semestre da mobilização, e como, aliás, é natural, os impulsos reivindicatórios arrefeceram, as questões suscitadas (saúde, educação, transporte) fazem, como já faziam, parte da agenda habitual de demandas das sociedades industriais modernas, além do clamor por segurança pública, e as instituições voltaram a funcionar como de costume. Como de costume, ao contrário do que se supõe, não significa instituições livres de vigilância. Existem centenas de milhares de organizações, representando milhões de pessoas, ou seja, de eleitores, a bater na porta dos parlamentos e das agências burocráticas oficiais. Claro está, nem todas as organizações estão mobilizadas ao mesmo tempo para, interrompendo suas atividades cotidianas, assediar os poderes públicos. Mas são em número suficiente para mantê-los sob razoável dose de vigilância.

O cerco cívico aos poderes públicos é fenômeno das democracias de massa, urbanizadas, e de baixos custos organizacionais. Fragmentados os interesses entre miríades de associações, cada qual presta atenção particularmente à ação pública que lhe diz respeito, enquanto o público em geral só tem notícia do que é revelado pelos meios de comunicação. Daí a aparência de inércia. As associações de interesse, contudo, têm conhecimento do que efetivamente ocorre. Em particular, estão atentas para os movimentos de associações concorrentes (do mesmo interesse) ou adversárias (organizações de vontades opostas). A competição no meio da sociedade civil é um dos mais importantes fenômenos resultantes do número de interesses e de associações, mantidos os parâmetros de uma sociedade democrática.

Ainda que a previsão da dinâmica política fosse trivialmente conservadora, os insumos da atividade de administrar conflitos e alocar bens e valores seriam alterados pela magnitude da população, da urbanização, da comunicação política, da especialização do trabalho e da expansão associativa. A resposta do sistema político - quer dizer, no caso, parlamento, Executivo e burocracia pública dependerá, em grandes linhas, do tipo de jogo em desenvolvimento: se de soma negativa, de soma constante ou de soma em expansão. É o que segue em aproximação ao final deste capítulo.

\section{Cenários de Futuro}

O cenário pessimista do Brasil em 2030 se materializa na emergência de um jogo de soma negativa. "Soma negativa" se refere a uma competição em torno de um conjunto decrescente de bens. Em consequência, todos os membros da competição perdem em termos absolutos, e a disputa se dá pela manutenção da participação relativa no consumo ou controle dos bens. A possibilidade de não 
haver perda absoluta de bens só se verifica mediante acirramento crítico dos conflitos, visto que a não perda de alguns implica necessariamente perdas ainda maiores para outros. Em geral, isso ocorre em sociedades nas quais existem grandes agregados humanos sem capacidade de defesa, grupos extremamente vulneráveis. Em tais casos, o índice de desigualdade cresce substancialmente.

As perspectivas para o Brasil, nesse particular, não parecem aceitar como plausível tal cenário, pelas razões expostas até aqui. Aliás, o índice de Gini vem caindo sistematicamente, independentemente da orientação do governo em exercício. Por isso, o cenário pessimista adotado se afasta de uma hipótese tão radical, acreditando na viabilidade de versões mais bem temperadas. De todo modo, a redução no conjunto total de bens e valores não deixa de ter repercussões diferenciadas na sociedade. Com o recadastramento eleitoral de 1958, por exemplo, depois de expurgado de enorme eleitorado fantasma, o número de eleitores brasileiros reduziu-se significativamente. O valor do bem "voto" foi altamente inflacionado e os partidos lutaram para não perder o número proporcional de cadeiras, sabendo que, naturalmente, competiam com maior número de candidatos (número crescente desde então e até hoje) por menor quantidade de votos. Economicamente o processo se dá, quer por via de inflação descontrolada (quando a moeda perde valor), quer por queda no Produto Interno Bruto do país.

Em contexto de soma negativa, os conflitos basicamente distributivos, em que não há nem mesmo a questão de políticas redistributivas, adquirem perigosa intensidade. A competição social se acentua, isto é, com tensões dentro dos mesmos estamentos, além do calor exacerbado das disputas entre estamentos com capacidade de mobilização de apoios. Nesse particular, fica esclarecido o sentido em que a extensão associativa da sociedade se torna fonte ora de sustentáculo, ora de obstáculo à execução de políticas de qualquer natureza. A real perspectiva de perda absoluta assustará algumas das associações, sobretudo as que cobrem grupos vulneráveis, fazendo crescer a ameaça de que a taxa de desigualdade então existente venha a aumentar, conforme o cenário pessimista radical prevê. Essa possibilidade não se apresentará como fruto do acaso (a fortuna de Maquiavel), mas como resultado altamente provável do suceder dos anos ao longo dos eixos aqui desenhados, na ausência de ação contrária. A administração dos conflitos inevitáveis no contexto pessimista dependerá, mais do que em outras circunstâncias, da virtù, da competência da liderança política incumbida do governo no período, sendo realista esperar que as oposições atribuam ao governo, sempre, a responsabilidade pelo que de infeliz se passe no país. Crucial, em particular, é a audiência que as oposições consigam cativar em momentos semelhantes. A estabilidade política no sentido fraco (eleitoral) tanto quanto no forte (manifestações, greves, confrontos) será função, no contexto, do sucesso da oposição em retirar do governo a iniciativa de ação, mantendo as demandas à frente da capacidade do governo em atendê-las. A virtù do governo estará depositada em sua capacidade de mobilizar a rede de associações ameaçadas, bem como seu apoio parlamentar, com o objetivo de evitar a implantação do cenário pessimista radical.

Assim, o cenário pessimista aqui descrito ainda pode ser considerado o menor dos males, à medida que o governo labuta e é bem-sucedido no desejo de evitar que o ordenamento social se deteriore, assegurando a manutenção do status quo. O cenário pessimista é o cenário conservador em sentido estrito, em que os poderes públicos não conseguem mais do que a reprodução do sistema. 
A longo prazo, e devido ao mecanismo de transformar quantidade em novidade, tal situação se tornará insustentável, degenerando em conflitos de desenlace imprevisível, ou conseguirá obter alternativa favorável e positiva na relação aspiração/realidade, pelo menos da maioria da população. Disso trata o próximo cenário.

Um futuro possível e positivo se apresenta quando todos os processos descritos e conservadoramente projetados transcorrem em contextos de soma constante. A expressão "soma constante" designa uma situação em que os parâmetros e variáveis em causa aumentam de valor bruto, sem que, contudo, seja alterada a posição relativa dos grupos participantes. Nesse contexto, é possível subtrair verdadeiras multidões da situação de miséria, sem que se modifique a taxa de desigualdade na distribuição agregada de bens e valores. O que é constante, portanto, é o hiato entre os estamentos sociais, precisamente porque todos progridem mais ou menos à mesma velocidade ou na conquista das mesmas porções do bolo. Para os que se encontram na base da pirâmide social, trata-se de uma situação altamente bem-vinda, estando a ênfase colocada nos aspectos brutos das condições de vida. No outro extremo, os grupos privilegiados não percebem ou cogitam estar sofrendo nenhum processo de privação relativa, ou seja, perdendo posições para concorrentes do mesmo estatuto ou de estatutos adversários. Em termos absolutos, todos melhoram, mas a estratificação social não sofre modificações em seu perfil histórico.

Politicamente, o contexto se reflete no que se considera a política normal. Os conflitos e competições continuam a existir dentro da sociedade e entre a sociedade e o poder político, mas a conciliação deles em torno de melhorias pontuais e conservadoras é possível. Ao contrário do que costuma ser entendido, uma política conservadora não está comprometida com a inércia ou imutabilidade. O que permanece ao longo dos anos é a estrutura de desigualdades característica da sociedade em questão. É possível o progresso sem mudança social e até mesmo o progresso com intensificação das desigualdades. Em perspectiva, parece ter sido o caso do materialmente bem-sucedido período JK. Praticamente, todos os competidores bem organizados (o que excluía, portanto, à época, os trabalhadores rurais) ganharam, mas alguns grupos, os de renda mais alta, ganharam proporcionalmente muito mais do que outros. Por essas razões é que se denominou de cenário conservador o cenário anterior, no qual a ação do governo se destinava a evitar a deterioração de perda absoluta. Aqui, trata-se de preservar a estrutura proporcional em contexto de crescimento absoluto.

As tensões derivadas do entrecruzar de demandas em uma enorme população, vivendo quase absolutamente em áreas urbanas, organizadas, com crescente e difundida capacidade de comunicação instantânea, tendem, no cenário atual, a considerar satisfatórias as instituições de participação existentes. Por "instituições" entendem-se, inclusive, as rotinas de diálogo direto entre grupos sociais e setores governamentais e burocráticos. Tal aspecto desse cenário mais otimista é que o torna superior ao cenário pessimista, no qual as instituições perdem eficácia, e a estabilidade democrática depende das virtudes da liderança política no governo e na oposição. Possível e positivo, este, todavia, é um cenário conservador no sentido em que o termo é aqui empregado. E não parece haver obstáculos previsivelmente intransponíveis a um terceiro cenário, que seja simultaneamente possível e desejável, elaborado, não obstante, segundo os princípios do realismo político. Trata-se do cenário de uma soma em expansão. 
A expressão "soma em expansão" aponta para um contexto em que há crescimento absoluto no conjunto de bens e valores disponíveis, e no qual todos os grupos ganham, isto é, progridem materialmente, embora alguns progridam mais do que outros. Trata-se de um cenário redistributivista que se aplica, em sua versão negativa, a momentos de aumento nos índices de desigualdade, amortecidos na consciência dos perdedores de alta renda pela melhora real em sua situação absoluta. Em sua versão positiva, contudo, a redistribuição opera em sentido oposto ao anterior: todos ganham, mas os grupos na base da sociedade ganham mais, proporcionalmente, do que aqueles que se encontram no topo, com isso não só atendendo melhor à razão aspiração/realidade de todos, mas em escala superior entre os grupos miseráveis e pobres.

Como é fácil de identificar, tal é o que vem ocorrendo no Brasil na última década em escala admirável e inédita. Para tanto contribuiu largo período em que a soma era de fato em expansão, passando a constante nos anos 2010-2012, no que se refere à geração de bens. O que se apresenta, portanto, é a manutenção de mecanismos redistributivos em favor dos estamentos mais pobres em contexto de relativa escassez de bens, caracterizado, no caso, por modestíssimo crescimento na oferta de produtos. Por isso a taxa de redistribuição é sofrida pelo topo da pirâmide como perda absoluta na sua razão aspiração/realidade, quando, de fato, o que transparece nos dados é a continuidade de um ganho geral, embora mais modesto do que no passado recente. A fonte de conflitos, porém, encontra-se na constância da transferência de bens, por meio dos programas de ampla envergadura nas áreas de renda, alimentação, saúde, educação e saúde, principalmente, fazendo com que a razão aspiração/realidade das classes abastadas continue positiva, mas relativamente menor.

Em fins de 2013, cenários e realidade se defrontam em combinação singular: continua-se uma política redistributiva em contexto de soma relativamente constante, o que recomendaria uma política conservadora, na semântica deste texto. Contudo, a orientação das políticas públicas permanece redistributiva. Além de variáveis específicas de conjuntura, esta é a configuração macro do modelo, ou cenário, em desenvolvimento. É baixa, porém, a probabilidade de que permaneça viável por tempo indeterminado. Ainda que a liderança política revele excepcional virtù na persuasão dos atores relevantes, sua eficácia tende a se reduzir ao longo do tempo. A curva das aspirações de todos os grupos sociais, uma vez posta em movimento ascensional, resiste a sofrer interrupções ou mesmo freios em sua velocidade. A mais sólida expectativa de estabilidade governamental reside na transformação da soma constante em soma em expansão. Mas, para tanto, são necessárias condições favoráveis, como o contexto internacional, por exemplo, que escapam a este exercício como, de resto, escapam em grande medida à capacidade de intervenção do Brasil. O tempo em que tais condições puderem ser admitidas como submetidas a manipulações, em exercícios como o presente, será aquele em que o país terá atingido o estágio de ator internacional, demiúrgico, isto é, capaz de alterar os dados do mundo. Por ora, a cautela recomenda tratar a moldura global como coeteris paribus, sendo motivo de esperança reconhecer que o Brasil já dispõe de graus de autonomia interna para decidir, democraticamente, sobre as políticas que melhor atendam sua razão aspirações/realidade. Se a realidade constrange, as aspirações libertam. 


\section{Referências}

INSTITUTO BRASILEIRO DE GEOGRAFIA E ESTATÍSTICA (IBGE). Sinopse do Censo Demográfico 2010. Disponível em: <www.ibge.gov.br/home/estatistica/populacao/censo2010/tabelas_pdf/Brasil_tab_1_4.pdf>. Acesso em: 15 jan. 2014.

INSTITUTO BRASILEIRO DE GEOGRAFIA E ESTATÍSTICA (IBGE). Pesquisa Nacional por Amostra de Domicílios. Rio de Janeiro: IBGE, 2011.

INSTITUTO BRASILEIRO DE GEOGRAFIA E ESTATÍSTICA (IBGE). As Fundações Privadas e Associações sem Fins Lucrativos no Brasil 2010. Rio de Janeiro: IBGE, 2012.

INSTITUTO DE PESQUISAS ECONÔMICA E APLICADA (IPEA). Brasil em Desenvolvimento 2013: Estado, planejamento e políticas públicas. Brasília: Ipea, 2013. 



\title{
DINÂMICA DEMOGRÁFICA E DISTRIBUIÇÃO ESPACIAL DA POPULAÇÃO: O ACESSO AOS SERVIÇOS DE SAÚDE
}

\author{
Antônio Tadeu Ribeiro de Oliveira \\ Maria Monica Vieira Caetano O’Neill
}

O Brasil vem experimentando transformações importantes em seus componentes demográficos: o processo veloz e continuado na redução dos níveis da fecundidade, que vem impactando na diminuição das taxas de natalidade; o envelhecimento populacional, reflexo da própria redução da fecundidade, do aumento relativo e absoluto da população idosa e da esperança de vida ao nascer (E0); e as mudanças na direção dos fluxos migratórios, que cada vez mais se destinam às cidades médias, com redução na participação relativa nas grandes metrópoles. Essas transformações, combinadas ao comportamento da distribuição espacial da população, fruto dos novos arranjos locacionais das atividades econômicas pelo território nacional, vêm imprimindo nos últimos vinte anos uma nova dinâmica demográfica ao país, que deve ser mais bem compreendida, inclusive no que tange aos seus impactos na transição epidemiológica e no acesso aos equipamentos e serviços de saúde.

Em relação aos cenários demográficos traçados em estudo anterior (Oliveira \& Oneill, 2013), as recentes projeções divulgadas pelo Instituto Brasileiro de Geografia e Estatística (IBGE), muito embora ratifiquem o diagnóstico e as tendências futuras apontadas, revisaram alguns indicadores, como já antecipávamos, fundamentalmente a taxa de fecundidade total (TFT) e a taxa de mortalidade infantil (TMI). Essa revisão implicou um ritmo mais lento no declínio da fecundidade, retardando em alguns anos a diminuição no tamanho da população brasileira.

Uma vez tendo avançado no diagnóstico e na construção de cenários para a transição demográfica brasileira para o nível macro, no horizonte de 2030, a questão que se coloca é a investigação dos efeitos dessas transformações na escala subnacional. Resguardados os diferenciais regionais, a tendência de redução nos níveis da fecundidade e da mortalidade aponta para a convergência desses indicadores em todo o espaço nacional, implicando a redução do número de crianças e o aumento da longevidade. Nesse sentido, o comportamento dos movimentos migratórios internos ditará, na maioria dos casos, não só o ritmo de crescimento dos espaços sub-regionais e, consequentemente, dos respectivos municípios, como também a estrutura por sexo e idade dessas populações, sem esquecer os movimentos pendulares que impactarão a demanda por acesso ao mercado de trabalho e serviços, em especial, os de saúde.

Dessa forma, espera-se que uma política de saúde, com dimensões abrangentes do ponto de vista econômico, social, político e territorial, seja tanto eficiente e duradoura, quanto inclusiva, no sentido 
de assistir e incorporar os mais variados segmentos populacionais nas diferentes regiões do país. No caso da saúde, o planejamento sob a ótica territorial permite direcionar a localização de investimentos e serviços (públicos e privados), assim como possibilitar maior acesso da população aos serviços.

A análise preliminar, relacionada ao cenário demográfico, sua dinâmica e distribuição espacial, aliada ao exame dos fluxos de internações para procedimentos de alta e média complexidade, preparados no contexto da iniciativa Brasil Saúde Amanhã (Oliveira \& O’Neill, 2013), permitiu afirmar que a oferta dos serviços de atendimento à saúde estaria repetindo o padrão de assimetrias mais geral, deixando à margem do acesso à saúde parcela significativa da população. A saúde apresenta uma configuração espacial desigual, beneficiando, de forma diferenciada, grupos sociais e lugares.

A superação das distorções que ocorrem no âmbito da distribuição e acesso a serviços de saúde aflora como uma questão crucial que pressupõe a ação do Estado, por meio da identificação e classificação de um conjunto de polos urbanos e suas regiões imediatas de articulação urbana a serem incentivados e destinados a ampliar e conformar redes de atendimento à saúde.

Para tratar dessas questões, o capítulo está estruturado de forma a inicialmente apresentar os indicadores demográficos associados ao comportamento da fecundidade (TFT); os relacionados à estrutura etária da população, como a razão de dependência total (RDT), de idosos (RDI) e o índice de envelhecimento (IE); os que dizem respeito à mortalidade (E0 e TMI); e a mobilidade espacial interestadual da população, vista a partir dos saldos migratórios, sempre destacando e enfatizando os diferenciais regionais.

Em seguida, para definir o quadro territorial dos centros de saúde e suas regiões de influência imediata, foi utilizada a Divisão Urbano-Regional (IBGE, 2013a), mais especificamente as regiões imediatas de articulação urbana (Figura 1), delimitadas a com base no estudo Regiões de Influência das Cidades - 2007 (IBGE, 2008). As regiões imediatas possuem, de maneira geral, tamanho populacional e áreas menores que as de nível intermediário, e suas ligações refletem a acessibilidade e a capacidade de atender demandas de amplitude mais restritas.

Utilizar a Divisão Urbano-Regional como referencial espacial para analisar e atuar no território significa privilegiar os núcleos da rede urbana e suas regiões de articulação, obtidos com base na combinação de dois processos: urbanização e integração do mercado nacional. As interações espaciais ocorrem conformando redes com alcance e intensidade variados e expressam a inserção diferenciada de cada centro na estrutura produtiva do país. A rede urbana, nesse contexto, exerce papel fundamental, contribuindo como o principal lócus na decisão e ação direta do governo no cotidiano das pessoas.

Na caracterização dos polos de saúde, foram utilizados critérios de saúde e populacionais que forneceram os perfis dos polos e de suas regiões de articulação. As unidades territoriais utilizadas são os municípios adotados pela Divisão Urbano-Regional (IBGE, 2013a), com a identificação dos polos e as vinculações com as regiões de articulação a que pertencem. Os critérios populacionais utilizados caracterizam os lugares segundo o tamanho e a dinâmica de seu crescimento até 2033. 
Figura 1 - Divisão Urbano-Regional - regiões imediatas de articulação

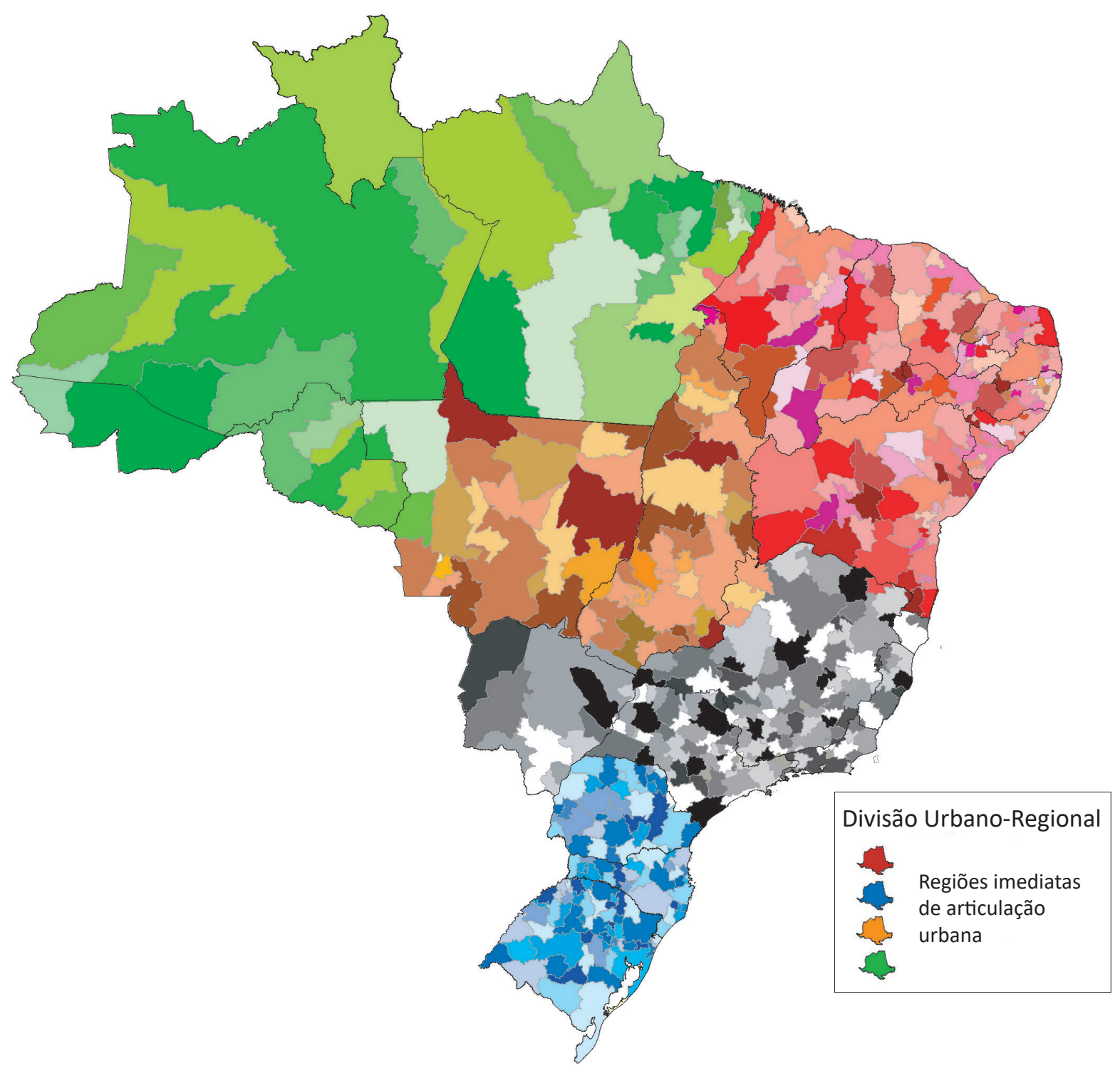

Fonte: elaboração dos autores com base em dados do IBGE - Coordenação de Geografia/Diretoria de Geociências.

O estudo Regiões de Influência das Cidades - 2007 (IBGE, 2008) foi a fonte analítica para definir os níveis de centralidade em saúde. Esses níveis expressam a capacidade que determinados serviços de saúde têm de dotar os centros urbanos com graus de atratividade diferenciados em suas áreas de atuação, ou ainda, o papel que os centros têm como distribuidores de bens e serviços de saúde para a população. Os resultados qualificam os centros que se posicionam entre os menos especializados até os mais especializados, com menor ou maior complexidade em serviços e capacidade de atendimento hospitalar, consequentemente, com níveis de centralidade menores e maiores. 


\section{Os Indicadores Demográficos e os Diferenciais Regionais}

Como mencionado anteriormente, o cenário futuro para o comportamento da dinâmica demográfica brasileira se alterou ligeiramente com a divulgação recente das projeções populacionais (IBGE, 2013b). Com essa mudança, no ano de 2030, o volume populacional atingirá a cifra de 223,1 milhões (7 milhões de habitantes a mais, resultado obtido, sobretudo, em virtude do declínio mais lento das taxas de fecundidade das mulheres brasileiras). Na revisão anterior, realizada em 2008, estimava-se que a TFT partiria de um patamar de 1,76 filho por mulher e chegaria a 1,5 em 2030. Com a atual revisão, o nível de partida foi de 1,87 filho por mulher, alcançando 1,51 em 2030. Como podemos observar, tanto em uma quanto na outra projeção, o ponto de partida para a hipótese do nível da fecundidade estava num patamar abaixo do de reposição (2,1 filhos por mulher). Mais à frente, quando formos tratar desses indicadores desagregados por unidade da federação (UF), veremos que a tendência é de convergência para níveis baixos das taxas de fecundidade.

Embora com indicadores finais muito próximos, a menor velocidade na redução dos níveis da fecundidade fez com que indicadores, como as razões de dependência, índice de envelhecimento populacional e o momento de redução no volume populacional, também se alterassem, mesmo que ligeiramente, em relação à projeção anterior.

Por exemplo, a RDT, ${ }^{1}$ que anteriormente voltaria a aumentar por volta de 2022 , quando teríamos 51,2 pessoas em idade não ativa para cada 100 em idade ativa (15 a 59 anos), agora inverterá sua tendência de declínio em 2020, alcançando a cifra de 53,2\%, o que significará uma pressão ligeiramente maior sobre aqueles que, hipoteticamente, estarão no mercado de trabalho. Ao decompormos a razão de dependência para jovens (RDJ) e idosos (RDI), observaremos que essa relação irá se alterando em favor do segmento com maior idade. Enquanto nos dias de hoje, essa relação é de cerca de 37,2 jovens e 16,9 idosos para cada 100 pessoas em idade ativa, em 2030 passaremos a ter aproximadamente 27,6 jovens e 29,2 idosos.

Esse processo de envelhecimento populacional fica ainda mais evidenciado quando verificamos o IE, que é a razão entre a população idosa e a jovem. Se na projeção anterior estimava-se 39 idosos para cada 100 jovens, em 2010, projetando-se para 2030, essa razão seria de 110,1 idosos. Com as novas projeções esses valores passaram a 39,3, em 2010, chegando em 2030 com um IE de 105,8\%. Aqui estamos falando de 41,5 milhões de pessoas com 60 anos ou mais de idade, mais do que o dobro observado em 2010 (19,6 milhões). Em comparação com a projeção anterior, embora tenhamos um IE menor, o volume de população idosa esperada é maior nesse novo cenário.

A população em idade ativa, por sua vez, continuará aumentando em volume até atingir seu ápice em 2033, quando teríamos cerca de 142,1 milhões de pessoas entre 15 e 59 anos de idade. A combinação desse fator, com a já anunciada maior participação da RDI e do IE, ocasionará sérios impactos na produtividade dessa força de trabalho, sem contar a sobrecarga sobre o sistema de saúde.

\footnotetext{
${ }^{1}$ Para guardar uma relação mais estreita com os indicadores utilizados na área da saúde, consideraram-se, no cálculo das razões de dependência e IE, os seguintes segmentos etários: idosos - 60 anos ou mais, jovens -0 a 14 anos, e idade ativa -15 a 59 anos.
} 
Nesse novo ritmo do processo de envelhecimento populacional, que refletirá a associação entre a diminuição da taxa bruta de natalidade, em decorrência da redução dos níveis de fecundidade, e o aumento das taxas brutas de mortalidade, em face do envelhecimento, chegaremos a um ponto no qual o crecimento vegetativo será negativo, o que deverá ocorrer no inicío dos anos 2040, quando atingiremos o máximo de 228,3 milhões de habitantes. Os Gráficos 1 e 2 sintetizam tais processos.

Gráfico 1 - Estimativas das taxas brutas de natalidade e mortalidade. Brasil - 2010 - 2060

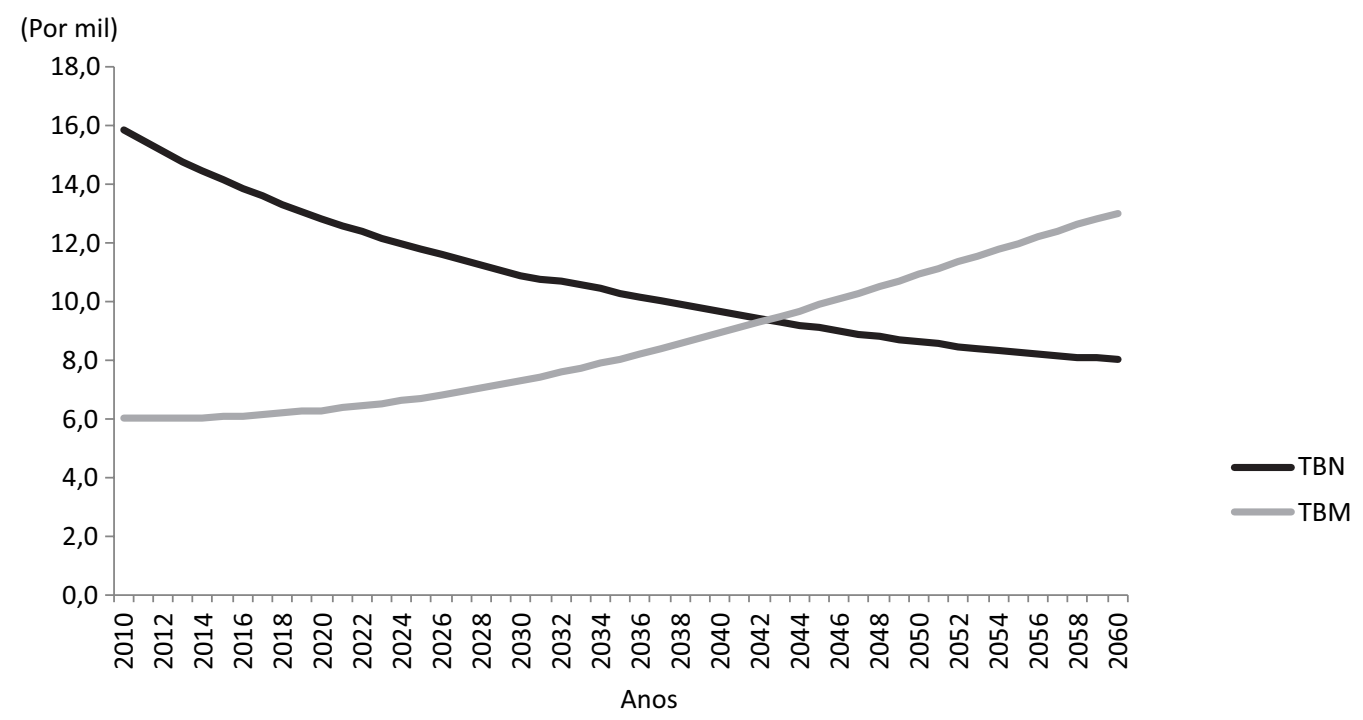

Fonte: elaboração dos autores com base em IBGE, 2013b.

Gráfico 2 - População residente em milhões. Brasil - 2010-2060

(Pop. em milhões)

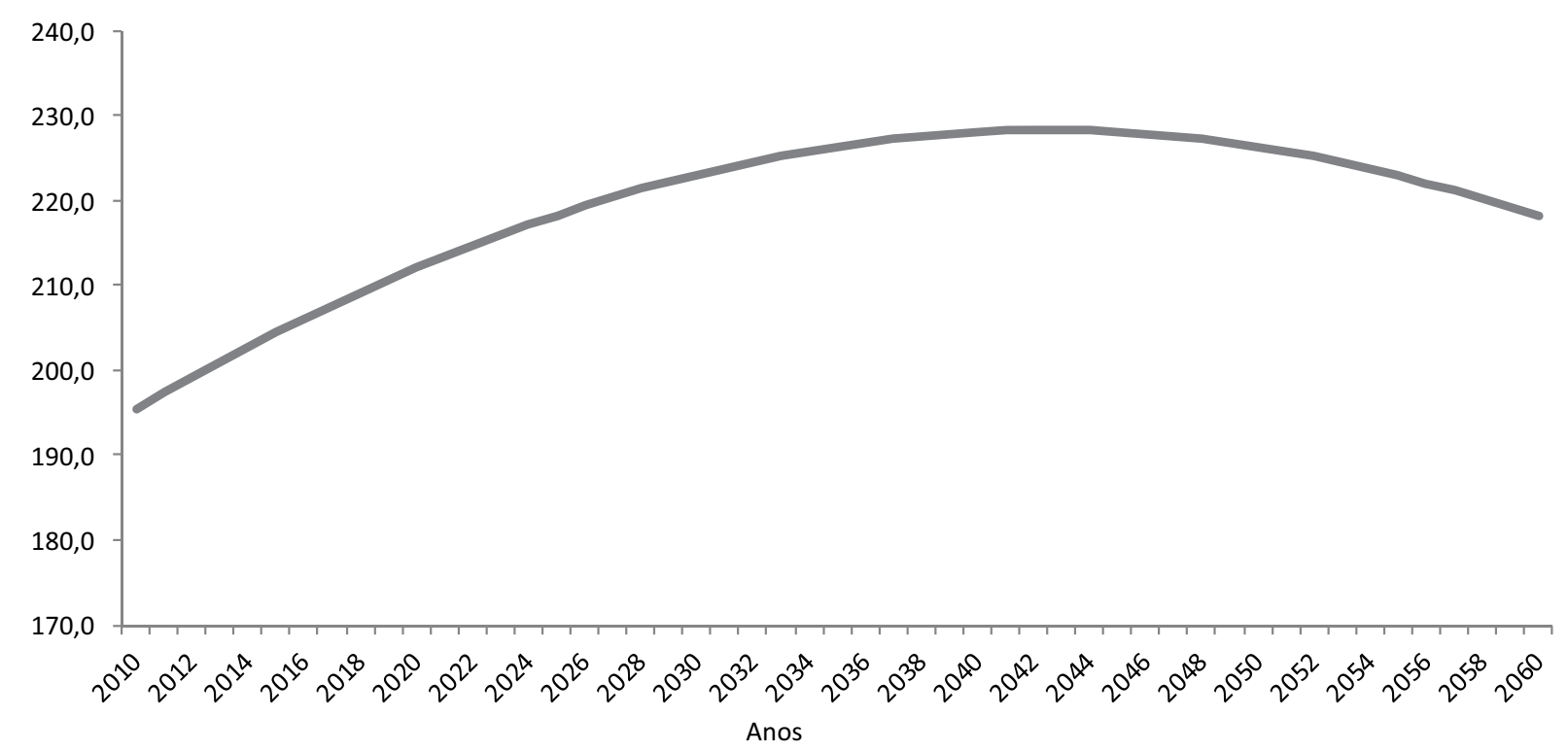

Fonte: elaboração dos autores com base em IBGE, 2013b. 
No que diz respeito aos indicadores sínteses da mortalidade, E0 e TMI, observamos que o primeiro não se alterará muito, estima-se que alcance o patamar de 78,6 anos em 2030, ou seja, um ganho de alguns meses em relação à estimativa anterior. Para a mortalidade infantil, entretanto, espera-se uma melhora significativa, como assinalamos em estudo anterior (Oliveira \& O'Neill, 2013). Esse indicador parte de 17,2 óbitos infantis para cada 1.000 vivos, em 2010, contra 21,6 óbitos no primeiro ano de vida, da estimativa anterior, chegando a uma TMI de nove óbitos infantis para cada 1.000 nascidos vivos. Com essa revisão, mais próxima da realidade, o Brasil atingiu a meta dos Objetivos do Milênio (ODMs), de 15 óbitos infantis, entre 2013 e 2014, antes, portanto, do prazo previsto pelos ODMs, que seria em 2015.

Outra novidade da nova projeção, que também havia sido pleiteada no estudo antecedente, diz respeito à incorporação das migrações internacionais, antes não consideradas. Agora estima-se que o Brasil experimentará saldos migratórios positivos, atingindo um ponto máximo entre 2016 e 2020, a partir do qual irá se reduzindo até tornar-se nulo de 2031 em diante. A hipótese é de que, diante do maior dinamismo econômico, a exploração do petróleo no pré-sal, os grandes eventos esportivos etc., observaremos tanto o retorno de brasileiros, que atualmente residem no exterior, como o aumento dos ingressos de pessoas dos países vizinhos, além da vinda de trabalhadores dos países desenvolvidos, que, em decorrência dos efeitos da crise econômica, já estão sendo atraídos, em certa medida, pela demanda por mão de obra qualificada.

Nunca é demais enfatizar que nosso olhar sobre os fenômenos associados à dinâmica demográfica brasileira apresentada anteriormente, como a que será tratada a seguir para as grandes regiões e UFs, parte do pressuposto que esses são produtos das relações sociais e processos históricos (Canales, 2001), que, portanto, respondem ao estágio de desenvolvimento econômico, social e cultural das sociedades onde estão inscritos. Da mesma forma, os cenários futuros que serão estabelecidos partirão dessa mesma lógica, isto quer dizer, responderão às condições concretas da vida social, naquilo que concernerá à determinação na formação econômica e social (Simões, 2006).

\section{Os diferenciais nos níveis da fecundidade}

Para escalas espaciais mais agregadas, como são as grandes regiões e as UFs, tudo indica que o ritmo de crescimento demográfico e a consequente evolução populacional serão ditados, sobretudo, pelo comportamento do nível da fecundidade, com contribuição menor dos componentes mortalidade e migração. Os diferenciais de fecundidade refletirão a velocidade com que cada uma das escalas espaciais analisadas evoluirá demograficamente.

A região Norte, que historicamente sempre apresentou as maiores TFTs, permaneceu como a única grande região na qual o nível da fecundidade se encontrava acima do de reposição, registrando, em 2010, uma TFT de 2,4 filhos por mulher; apenas Rondônia apresentava nível de fecundidade abaixo do de reposição $(1,96)$. Todas as demais UFs experimentavam taxas superiores a 2,1 filhos por mulher. Segundo as projeções populacionais vigentes, os níveis de fecundidade que não assegurariam a reposição populacional seriam alcançados inicialmente pela UF de Tocantins $(2,07)$, em 2012, 
estando previsto que a região Norte apresentaria TFT de 2,06, em 2016, e o Acre seria a última UF a chegar a esse patamar, em 2022, com 2,05 filhos por mulher. De acordo com as projeções, a TFT para as mulheres do Norte seria em média de 1,64 filho.

No Nordeste, em que pesem todas as assimetrias de desenvolvimento econômico e social, apenas duas UFs estavam, em 2010, com níveis de fecundidade acima do de reposição: Maranhão $(2,47)$ e Alagoas (2,22). A TFT média da região era de 2,02 filhos por mulher. Isto facilitou a convergência de todas as UFs para níveis inferiores ao de reposição, que seria alcançado por Alagoas (2,04), em 2013, e Maranhão $(2,07)$, em 2017. O que chama a atenção para o caso do Nordeste é que a estimativa para a fecundidade média da região (1,57 filho) é bem próxima às dos estados do Centro-Sul para o ano de 2030.

As regiões Sudeste e Sul são as que apresentavam os menores níveis de fecundidade, e todas as UFs registravam taxas ao redor de 1,7 filho por mulher, já para o ano de 2010. As estimativas sinalizam que as TFTs para o ano de 2030 serão de 1,45, bem próximas às dos países europeus que experimentam as mais baixas fecundidades.

No Centro-Oeste, embora a média da TFT $(1,83)$ estivesse, em 2010, abaixo do nível de reposição, duas UFs - Mato Grosso do Sul e Mato Grosso - apresentavam comportamento mais próximo ao do Nordeste, com taxas ao redor de 2,1; já Goiás e o Distrito Federal se assemelhavam ao Sudeste, com TFTs em torno de 1,7 filho por mulher. Para o ano 2030, estima-se que nesta região o nível da fecundidade atingirá valores entre 1,45 e 1,55 filho por mulher.

Em suma, ao se confirmarem os prognósticos implícitos na projeção oficial, as TFTs em todas as UFs, como demonstrado na Tabela 1, irão convergir para níveis semelhantes aos observados nos países desenvolvidos, que se encontram abaixo do patamar necessário para a reposição populacional. A Figura 2 mostra que, enquanto no ano de 2010 as taxas por UF se distribuíam por três faixas de valores, observando-se que em 17 estados estavam acima ou próximas ao nível de reposição, para 2030 o cenário se alterará completamente, quando nove estados do Centro-Sul apresentarão taxas abaixo de 1,5 filho por mulher e nos demais a TFT não ultrapassará o nível de 1,9. Em consequência, questões decorrentes da diminuição das taxas de natalidade, tais como redução do volume da população em idade ativa e envelhecimento irão se generalizar em todo o território nacional num horizonte curto de tempo. 
Tabela 1 - Taxa de fecundidade total, segundo Brasil, grandes regiões e unidades da federação 2010-2030

\begin{tabular}{|c|c|c|c|c|c|}
\hline \multirow{2}{*}{$\begin{array}{l}\text { Brasil, grandes regiões } \\
\text { e unidades da federação }\end{array}$} & \multicolumn{5}{|c|}{ Anos } \\
\hline & 2010 & 2015 & 2020 & 2025 & 2030 \\
\hline BRASIL & 1,87 & 1,72 & 1,61 & 1,55 & 1,51 \\
\hline Norte & 2,40 & 2,11 & 1,90 & 1,74 & 1,64 \\
\hline Rondônia & 1,96 & 1,77 & 1,65 & 1,59 & 1,55 \\
\hline Acre & 2,81 & 2,45 & 2,15 & 1,92 & 1,75 \\
\hline Amazonas & 2,59 & 2,26 & 1,99 & 1,79 & 1,65 \\
\hline Roraima & 2,58 & 2,20 & 1,93 & 1,76 & 1,65 \\
\hline Pará & 2,38 & 2,10 & 1,89 & 1,75 & 1,65 \\
\hline Amapá & 2,69 & 2,27 & 1,98 & 1,80 & 1,70 \\
\hline Tocantins & 2,18 & 1,93 & 1,77 & 1,66 & 1,60 \\
\hline Nordeste & 2,02 & 1,82 & 1,69 & 1,61 & 1,57 \\
\hline Maranhão & 2,47 & 2,17 & 1,93 & 1,76 & 1,65 \\
\hline Piauí & 1,97 & 1,77 & 1,65 & 1,58 & 1,55 \\
\hline Ceará & 1,96 & 1,76 & 1,64 & 1,58 & 1,55 \\
\hline Rio Grande do Norte & 1,91 & 1,74 & 1,64 & 1,58 & 1,55 \\
\hline Paraíba & 1,97 & 1,79 & 1,67 & 1,60 & 1,55 \\
\hline Pernambuco & 1,94 & 1,77 & 1,66 & 1,59 & 1,55 \\
\hline Alagoas & 2,22 & 1,94 & 1,77 & 1,66 & 1,60 \\
\hline Sergipe & 1,97 & 1,76 & 1,64 & 1,58 & 1,55 \\
\hline Bahia & 1,89 & 1,74 & 1,64 & 1,58 & 1,55 \\
\hline Sudeste & 1,70 & 1,59 & 1,52 & 1,48 & 1,45 \\
\hline Minas Gerais & 1,72 & 1,59 & 1,52 & 1,47 & 1,45 \\
\hline Espírito Santo & 1,75 & 1,63 & 1,54 & 1,49 & 1,45 \\
\hline Rio de Janeiro & 1,68 & 1,58 & 1,52 & 1,48 & 1,45 \\
\hline São Paulo & 1,70 & 1,59 & 1,52 & 1,48 & 1,45 \\
\hline Sul & 1,70 & 1,59 & 1,52 & 1,47 & 1,45 \\
\hline Paraná & 1,76 & 1,63 & 1,54 & 1,49 & 1,45 \\
\hline Santa Catarina & 1,65 & 1,55 & 1,50 & 1,47 & 1,45 \\
\hline Rio Grande do Sul & 1,67 & 1,56 & 1,50 & 1,47 & 1,45 \\
\hline Centro-Oeste & 1,83 & 1,69 & 1,60 & 1,53 & 1,49 \\
\hline Mato Grosso do Sul & 2,02 & 1,86 & 1,73 & 1,63 & 1,55 \\
\hline Mato Grosso & 2,01 & 1,85 & 1,72 & 1,62 & 1,55 \\
\hline Goiás & 1,74 & 1,61 & 1,53 & 1,48 & 1,45 \\
\hline Distrito Federal & 1,65 & 1,56 & 1,50 & 1,47 & 1,45 \\
\hline
\end{tabular}

Fonte: elaboração dos autores com base em IBGE, 2013b. 
Figura 2 - Taxa de fecundidade total, segundo unidades da federação. Brasil - 2010 e 2030

Brasil 2010

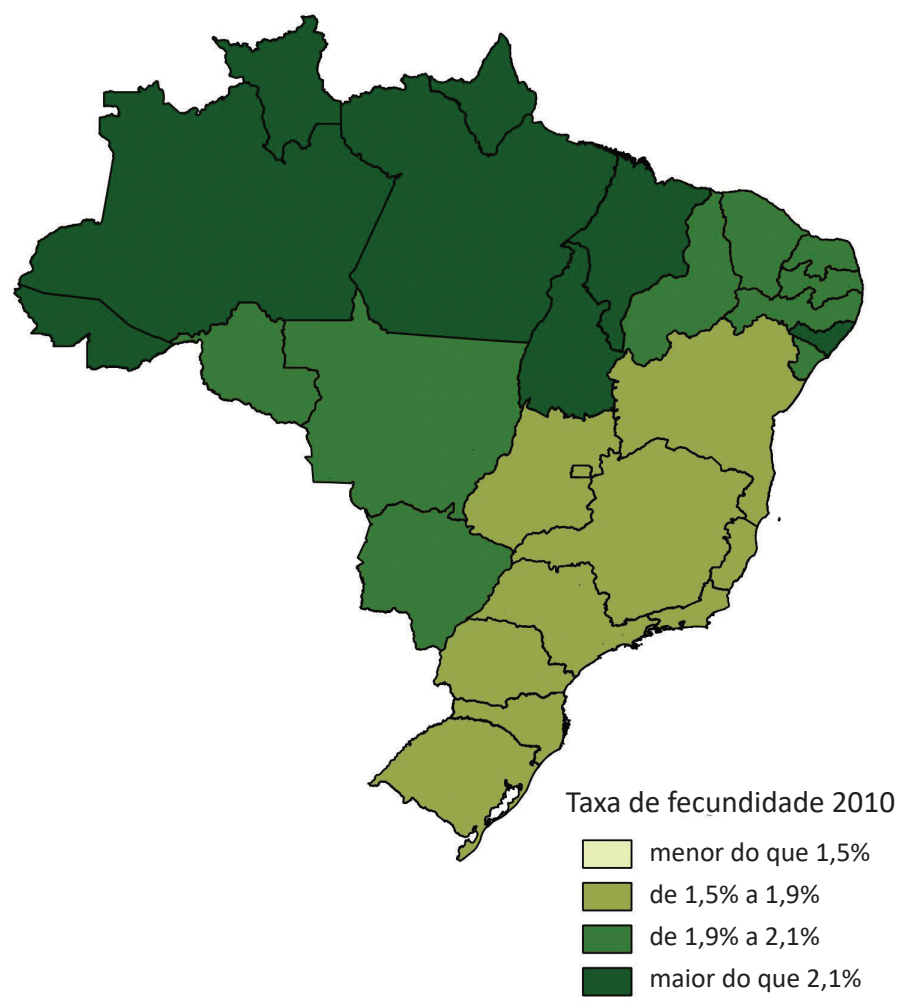

Brasil 2030

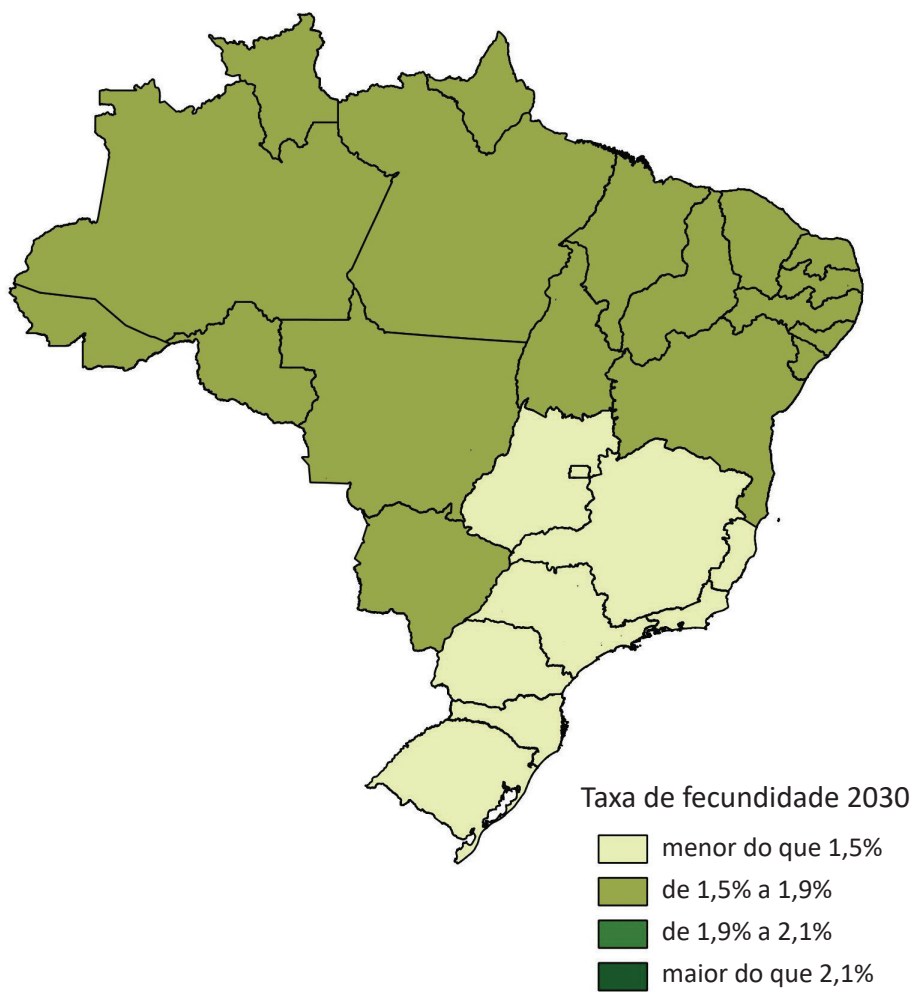

Fonte: elaboração dos autores com base em IBGE, 2013b.

\section{Características gerais da população}

Os indicadores de RDT e E0, que resultam diretamente da evolução das taxas de fecundidade, possibilitam perceber de forma mais nítida a diversidade e os diferenciais regionais na transição demográfica brasileira, corroborando a tese de que a dinâmica demográfica reflete o desenvolvimento econômico, social e cultural das respectivas sociedades.

No caso brasileiro, observa-se claramente que o Sudeste e o Sul se encontram num estágio mais avançado da transição demográfica. Espera-se o aumento nas razões de dependência já nos anos 2010, enquanto o Norte e o Nordeste ainda têm um período de tempo mais longo a usufruir da chamada "janela de oportunidade" demográfica, uma vez que a razão de dependência seguirá diminuindo, em boa parte das UFs, até o horizonte da projeção, em 2030. O Centro-Oeste atravessa um estágio intermediário, contudo mais próximo da realidade do Norte-Nordeste, dado que o IE, apesar da trajetória ascendente, apresentará, na composição do indicador, uma maior participação do segmento jovem, ao passo que as RDTs reverterão a tendência de queda ainda na presente década, num modelo mais semelhante ao do Sudeste-Sul. 
Em relação às razões de dependência, apresentadas na Tabela 2, é importante ressaltar que para aquelas UFs nas quais a etapa da transição demográfica está mais adiantada, no horizonte da projeção, em 2050, espera-se que as RDTs sejam próximas às constatadas no início do período, em 2010, sobretudo no Centro-Oeste, destacando-se que o segmento de idosos passará a ter maior participação na composição do indicador, o que resultará em uma mudança qualitativa importante.

Decompondo-se o indicador RDT por segmento jovem e idoso, observaremos que, mesmo no período no qual a tendência de indicador será de queda, a parcela da população com 60 anos ou mais de idade crescerá de forma ininterrupta, enquanto os de 0 a 14 anos apresentam comportamento contrário. Entre outros fatores de relevada importância, e que estão associados às RDIs, destaca-se um que está diretamente ligado ao crescimento econômico, devido à exaustão do aumento da oferta de força de trabalho, implicando uma redução da taxa de poupança, e consequentemente, refletindo no processo de acumulação do capital. Estudo de Pereima e Porsse (2013) mostra que, quando a RDI supera os $12 \%$, para que seja mantido o ciclo de acumulação, o desenvolvimento econômico dependerá das inovações tecnológicas e dos ganhos de produtividade da força de trabalho.

Tabela 2 - Razão de dependência total, segundo Brasil, grandes regiões e unidades da federação 2010-2030

\begin{tabular}{|l|l|l|l|l|l|}
\hline \multicolumn{1}{|c|}{$\begin{array}{c}\text { Brasil, grandes regiões } \\
\text { e unidades da federação }\end{array}$} & \multicolumn{5}{c|}{ Anos } \\
\hline BRASIL & 2010 & 2015 & 2020 & 2025 & 2030 \\
\hline Norte & 55,20 & 53,61 & 53,16 & 54,51 & 56,77 \\
\hline Rondônia & 63,33 & 58,42 & 53,95 & 51,12 & 49,99 \\
\hline Acre & 53,81 & 50,09 & 47,15 & 47,03 & 48,46 \\
\hline Amazonas & 70,54 & 64,72 & 58,84 & 54,37 & 51,83 \\
\hline Roraima & 65,70 & 59,93 & 55,09 & 51,56 & 49,29 \\
\hline Pará & 65,64 & 59,62 & 53,73 & 50,26 & 48,64 \\
\hline Amapá & 63,61 & 58,94 & 54,63 & 51,65 & 50,44 \\
\hline Tocantins & 68,44 & 61,15 & 53,93 & 49,82 & 48,61 \\
\hline Nordeste & 61,08 & 57,02 & 53,04 & 51,25 & 51,53 \\
\hline Maranhão & 60,00 & 56,74 & 53,97 & 53,33 & 54,35 \\
\hline Piaú́ & 68,54 & 64,60 & 59,26 & 54,77 & 52,28 \\
\hline Ceará & 60,91 & 58,01 & 54,22 & 52,91 & 53,71 \\
\hline Rio Grande do Norte & 60,41 & 56,02 & 52,93 & 52,98 & 54,48 \\
\hline Paraíba & 57,67 & 54,32 & 51,91 & 52,66 & 54,74 \\
\hline Pernambuco & 60,16 & 57,98 & 55,28 & 54,59 & 55,48 \\
\hline Alagoas & 58,63 & 55,82 & 53,41 & 53,36 & 55,03 \\
\hline Sergipe & 63,82 & 59,59 & 55,54 & 53,80 & 54,33 \\
\hline Bahia & 58,26 & 53,89 & 50,31 & 50,06 & 51,89 \\
\hline
\end{tabular}


Tabela 2 - Razão de dependência total, segundo Brasil, grandes regiões e unidades da federação 2010-2030 (cont.)

\begin{tabular}{|l|l|l|l|l|l|}
\hline \multicolumn{1}{|c|}{$\begin{array}{c}\text { Brasil, grandes regiões } \\
\text { e unidades da federação }\end{array}$} & 2010 & 2015 & 2020 & 2025 & 2030 \\
\hline Sudeste & 52,26 & 51,83 & 53,02 & 55,86 & 59,26 \\
\hline Minas Gerais & 53,37 & 52,49 & 53,24 & 55,85 & 58,97 \\
\hline Espírito Santo & 51,42 & 50,65 & 51,64 & 53,82 & 56,48 \\
\hline Rio de Janeiro & 53,71 & 53,13 & 54,96 & 58,41 & 61,95 \\
\hline São Paulo & 51,27 & 51,15 & 52,35 & 55,14 & 58,71 \\
\hline Sul & 52,66 & 52,42 & 53,99 & 57,74 & 61,62 \\
\hline Paraná & 53,22 & 52,39 & 53,06 & 56,01 & 59,92 \\
\hline Santa Catarina & 49,22 & 48,71 & 50,52 & 54,36 & 58,06 \\
\hline Rio Grande do Sul & 54,16 & 54,80 & 57,27 & 61,93 & 66,07 \\
\hline Centro-Oeste & 51,22 & 49,45 & 48,72 & 49,97 & 52,31 \\
\hline Mato Grosso do Sul & 54,94 & 53,99 & 53,50 & 54,47 & 55,94 \\
\hline Mato Grosso & 52,37 & 51,17 & 50,44 & 51,24 & 53,07 \\
\hline Goiás & 51,36 & 49,18 & 47,94 & 49,03 & 51,46 \\
\hline Distrito Federal & 46,25 & 44,30 & 44,70 & 47,08 & 50,48 \\
\hline
\end{tabular}

Fonte: elaboração dos autores com base em IBGE, 2013b.

Na Figura 3, observamos que, em 2010, apenas os estados da região Norte, Mato Grosso e o Distrito Federal, nos quais o processo de envelhecimento populacional está mais retardado, experimentavam RDIs inferiores a $12 \%$. No entanto, a previsão para 2030 é de que em todas as UFs o indicador supere os $12 \%$, e nos estados do Sudeste e do Sul as RDIs sejam superiores a 30\%. Esse cenário impõe que políticas educacionais e econômicas sejam implementadas, de modo que o país possa gerar inovações tecnológicas, as quais produzam ganhos de produtividade que venham a compensar o inexorável envelhecimento populacional, possibilitando que o Brasil alcance um desenvolvimento econômico e social sustentado. 
Figura 3 - Razão de dependência total segundo unidades da federação. Brasil - 2010 e 2030

Brasil 2010

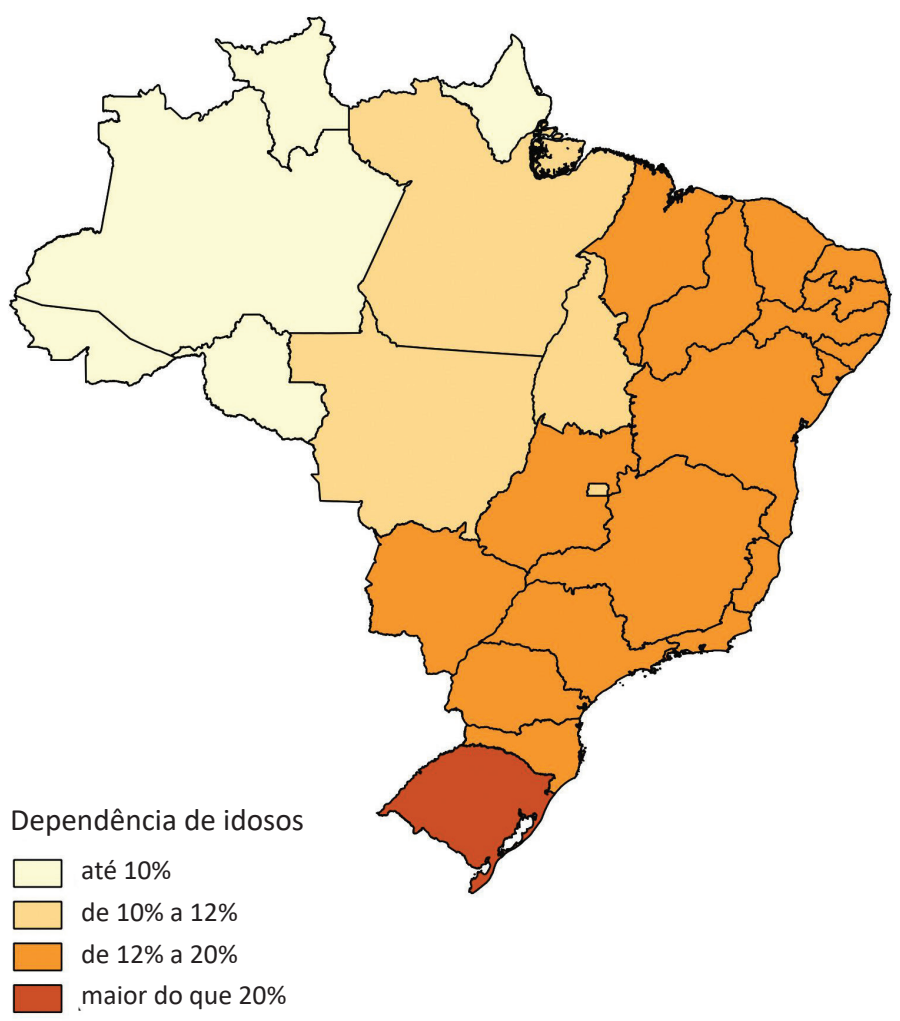

Brasil 2030

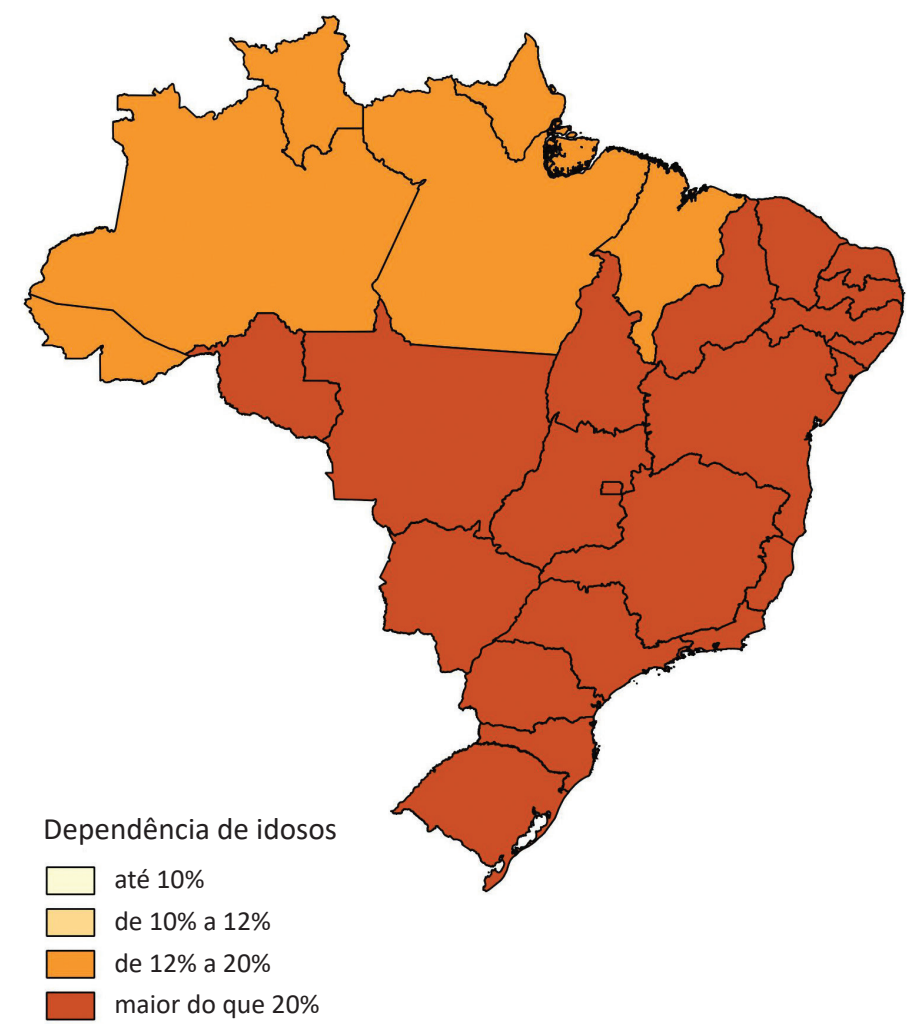

Fonte: elaboração dos autores com base em IBGE, 2013b.

No que diz respeito ao IE, observaremos uma trajetória generalizada de aumento em todo o território nacional. No Rio Grande do Sul, Rio de Janeiro e São Paulo, o fenômeno será mais intenso, dado que, no início dos anos 2020, o volume de população idosa superará o segmento jovem. Para os demais estados do Sudeste e do Sul, isto só ocorrerá mais para o final dessa década. Já nas UFs do Norte, Nordeste e do Centro-Oeste, o processo de envelhecimento ficará um pouco mais lento, resguardando-se o ritmo diferencial, sendo ligeiramente mais acentuado no Rio Grande do Norte, Bahia, Mato Grosso do Sul, Mato Grosso, Goiás e Distrito Federal, como demonstrado na Tabela 3. 
Tabela 3 - Índice de envelhecimento, segundo Brasil, grandes regiões e unidades da federação 2010-2013

\begin{tabular}{|c|c|c|c|c|c|}
\hline \multirow{2}{*}{$\begin{array}{l}\text { Brasil, grandes regiões } \\
\text { e unidades da federação }\end{array}$} & \multicolumn{5}{|c|}{ Anos } \\
\hline & 2010 & 2015 & 2020 & 2025 & 2030 \\
\hline BRASIL & 39,26 & 50,50 & 66,10 & 85,17 & 105,82 \\
\hline Norte & 18,42 & 23,65 & 31,48 & 42,04 & 55,07 \\
\hline Rondônia & 22,25 & 29,58 & 41,06 & 56,01 & 72,84 \\
\hline Acre & 15,91 & 19,82 & 25,86 & 33,92 & 44,84 \\
\hline Amazonas & 15,04 & 19,41 & 25,93 & 35,31 & 47,06 \\
\hline Roraima & 12,78 & 17,56 & 24,93 & 34,69 & 46,12 \\
\hline Pará & 19,59 & 25,01 & 32,95 & 43,43 & 56,50 \\
\hline Amapá & 12,14 & 16,39 & 23,38 & 32,91 & 44,67 \\
\hline Tocantins & 24,41 & 30,91 & 40,65 & 53,48 & 68,90 \\
\hline Nordeste & 32,13 & 39,49 & 50,62 & 65,67 & 83,09 \\
\hline Maranhão & 22,59 & 26,87 & 33,85 & 43,94 & 56,51 \\
\hline Piauí & 31,28 & 38,82 & 50,99 & 66,79 & 83,94 \\
\hline Ceará & 33,87 & 41,97 & 53,17 & 68,41 & 85,30 \\
\hline Rio Grande do Norte & 36,43 & 43,98 & 56,11 & 73,31 & 92,04 \\
\hline Paraíba & 39,22 & 45,44 & 55,67 & 70,97 & 88,96 \\
\hline Pernambuco & 34,72 & 42,46 & 54,52 & 70,62 & 88,96 \\
\hline Alagoas & 25,61 & 32,50 & 42,68 & 56,53 & 73,11 \\
\hline Sergipe & 27,75 & 35,11 & 46,12 & 60,23 & 76,21 \\
\hline Bahia & 34,46 & 43,35 & 56,24 & 72,74 & 92,20 \\
\hline Sudeste & 48,54 & 63,71 & 83,90 & 107,03 & 131,03 \\
\hline Minas Gerais & 46,64 & 60,73 & 80,22 & 103,25 & 127,25 \\
\hline Espírito Santo & 39,20 & 52,56 & 70,44 & 91,57 & 114,07 \\
\hline Rio de Janeiro & 55,59 & 72,98 & 94,23 & 117,12 & 139,21 \\
\hline São Paulo & 47,72 & 62,86 & 83,26 & 106,70 & 131,51 \\
\hline Sul & 50,13 & 66,28 & 87,04 & 111,19 & 135,55 \\
\hline Paraná & 44,26 & 58,47 & 77,44 & 100,75 & 126,26 \\
\hline Santa Catarina & 44,15 & 59,20 & 77,53 & 99,36 & 121,33 \\
\hline Rio Grande do Sul & 60,00 & 79,26 & 104,06 & 131,20 & 156,50 \\
\hline Centro-Oeste & 32,11 & 42,12 & 56,00 & 73,29 & 92,83 \\
\hline Mato Grosso do Sul & 33,92 & 43,02 & 56,38 & 73,99 & 93,69 \\
\hline Mato Grosso & 27,28 & 35,78 & 48,73 & 65,86 & 85,88 \\
\hline Goiás & 34,33 & 44,34 & 58,64 & 75,96 & 94,78 \\
\hline Distrito Federal & 31,06 & 44,11 & 58,63 & 75,47 & 95,53 \\
\hline
\end{tabular}

Fonte: elaboração dos autores com base em IBGE, 2013b. 
O comportamento esperado para os indicadores RDT e IE sinalizam que o Brasil irá experimentar duas ou três transições demográficas simultâneas. Embora tenhamos que nos preparar para o cenário de envelhecimento populacional, os diferenciais regionais demandarão políticas públicas específicas para cada região. Temos um quadro em que ainda é possível aproveitar o chamado "bônus demográfico", com aumento continuado da oferta da força de trabalho, em decorrência da tendência de crescimento da população em idade ativa. Essa janela ficará mais tempo aberta nos estados do Norte e Nordeste, justamente os que demandam políticas educacionais mais efetivas em infraestrutura e qualidade, onde o investimento pode gerar um melhor aproveitamento do bônus. No Centro-Sul, os investimentos nessa área deveriam estar mais voltados para os aspectos da qualidade, e não da estrutura física. Em contrapartida, os investimentos em saúde, proteção social e cuidados com a população idosa devem ser direcionados, a curto e médio prazos, para as regiões Sudeste e Sul, ficando o Norte e Nordeste para um segundo momento. Já para o Centro-Oeste o ideal é que as políticas nessas áreas sejam combinadas, uma vez que a região experimenta uma etapa da transição intermediária em relação às demais regiões.

\section{Indicadores de mortalidade}

Os indicadores de E0 e a TMI, apresentados, respectivamente, nas Tabelas 4 e 5, conseguem sintetizar, com certa propriedade, o estado geral da saúde da população. Ambos indicadores vêm apresentando resultados positivos nas últimas décadas, refletindo, sobretudo, a melhora nas condições de saúde e vida da população, expressas, entre outros, pelos seguintes fatores: maior capilaridade do Sistema Único de Saúde (SUS); expansão dos serviços de saneamento básico, apesar de ainda tímida; maior acesso aos sistemas previdenciário e de proteção social, em geral; aumento real do salário mínimo; e progressiva redução das desigualdades. Em relação à mortalidade infantil, além dos fatores mencionados, poderíamos agregar a ampliação da Estratégia Saúde da Família (ESF), o aumento das consultas pré-natal e do aleitamento materno, bem como das campanhas específicas voltadas para a redução dos óbitos infantis.

Embora venham diminuindo ao longo do tempo, os diferenciais regionais nesses indicadores ainda se fazem presentes, produto das assimetrias regionais no desenvolvimento econômico e social, como apresentado a seguir.

\section{Esperança de vida ao nascer}

A E0 no Norte do país, estimada para o ano de 2010, era de 70,8 anos. Entre as UFs dessa região, apenas Roraima (69,5 anos) apresentava um indicador inferior a 70,0 anos. No extremo oposto, com o melhor desempenho, aparecia o Acre com 72,3 anos. Projetando-se o comportamento da expectativa de vida para o ano de 2030, espera-se que no Acre, Amapá e Tocantins os valores sejam superiores a 76,0 anos, e as demais UFs fiquem ao redor de 74,0 anos.

No Nordeste, com expectativa de vida média ao redor de 71,2 anos, encontravam-se, em 2010, três estados com E0 inferiores a 70,0 anos: Maranhão $(68,8)$, Piauí $(69,9)$ e Alagoas $(69,2)$, reforçando a forte correlação entre o desempenho do indicador e o desenvolvimento econômico. As demais UFs estavam na faixa entre 71,0 e 74,0 anos. Para 2030, de acordo com a projeção, espera-se uma substantiva 
melhora nesse indicador: Maranhão $(74,0)$ e Piauí $(73,4)$ teriam as menores E0, e os outros estados apresentariam valores superiores a 76,0 anos, destacando-se o Rio Grande do Norte com 78,0 anos.

No Sudeste e no Sul, o Rio de Janeiro apresentou o pior desempenho entre todas as UFs, com E0 estimada, para 2010, em 74,2 anos, o que pode ser atribuído, em boa medida, aos óbitos por causas violentas. Nas demais regiões, a E0 superava os 75 anos. Projetando-se o comportamento do indicador, espera-se que todas as UFs dessas duas grandes regiões apresentem valores próximos ou superiores a 80 anos de vida.

O Distrito Federal destaca-se positivamente entre as UFs da região Centro-Oeste, partindo de uma expectativa de vida de 76,3 anos e chegando ao horizonte da projeção com 80,8 anos. Os demais estados, no início do período analisado, apresentavam valores próximos a 73,0 anos de vida ao nascer, estimando-se que deverão alcançar em 2030 uma esperança de vida entre 76,0 e 78,0 anos.

Tabela 4 - Esperança de vida ao nascer, segundo Brasil, grandes regiões e unidades da federação 2010-2013

\begin{tabular}{|l|l|l|l|l|l|}
\hline \multicolumn{1}{|c|}{ Brasil, grandes regiões } & \multicolumn{3}{|c|}{ Anos } \\
\hline B unidades da federação & 2010 & 2015 & 2020 & 2025 & 2030 \\
\hline Norte & 73,86 & 75,44 & 76,74 & 77,80 & 78,64 \\
\hline Rondônia & 70,79 & 72,00 & 73,06 & 73,97 & 74,76 \\
\hline Acre & 70,11 & 71,14 & 72,09 & 72,96 & 73,75 \\
\hline Amazonas & 71,68 & 73,61 & 75,09 & 76,18 & 76,99 \\
\hline Roraima & 70,37 & 71,67 & 72,81 & 73,81 & 74,67 \\
\hline Pará & 69,49 & 71,22 & 72,69 & 73,93 & 74,95 \\
\hline Amapá & 70,87 & 71,91 & 72,83 & 73,66 & 74,39 \\
\hline Tocantins & 72,13 & 73,66 & 74,88 & 75,82 & 76,55 \\
\hline Nordeste & 71,56 & 73,11 & 74,39 & 75,42 & 76,24 \\
\hline Maranhão & 71,23 & 72,81 & 74,13 & 75,23 & 76,13 \\
\hline Piauí & 68,75 & 70,28 & 71,67 & 72,93 & 74,04 \\
\hline Ceará & 69,92 & 70,87 & 71,76 & 72,60 & 73,38 \\
\hline Rio Grande do Norte & 72,40 & 73,62 & 74,68 & 75,60 & 76,37 \\
\hline Paraíba & 74,10 & 75,48 & 76,57 & 77,41 & 78,04 \\
\hline Pernambuco & 71,24 & 72,93 & 74,36 & 75,54 & 76,51 \\
\hline Alagoas & 71,13 & 73,48 & 75,31 & 76,69 & 77,68 \\
\hline Sergipe & 69,18 & 71,23 & 72,98 & 74,45 & 75,65 \\
\hline Bahia & 71,02 & 72,41 & 73,64 & 74,70 & 75,62 \\
\hline Sudeste & 71,92 & 73,23 & 74,36 & 75,32 & 76,13 \\
\hline Minas Gerais & 75,55 & 77,20 & 78,52 & 79,57 & 80,38 \\
\hline Espírito Santo & 75,51 & 76,97 & 78,19 & 79,19 & 79,99 \\
\hline Rio de Janeiro & 75,93 & 77,85 & 79,32 & 80,39 & 81,15 \\
\hline São Paulo & 74,20 & 75,88 & 77,30 & 78,47 & 79,42 \\
\hline
\end{tabular}


Tabela 4 - Esperança de vida ao nascer, segundo Brasil, grandes regiões e unidades da federação 2010-2013 (cont.)

\begin{tabular}{|l|l|l|l|l|l|}
\hline \multicolumn{1}{|c|}{$\begin{array}{c}\text { Brasil, grandes regiões } \\
\text { e unidades da federação }\end{array}$} & 2010 & 2015 & 2020 & 2025 & 2030 \\
\hline Sul & 75,87 & 77,49 & 78,88 & 80,05 & 81,03 \\
\hline Paraná & 75,15 & 76,78 & 78,21 & 79,43 & 80,47 \\
\hline Santa Catarina & 76,93 & 78,74 & 80,21 & 81,37 & 82,26 \\
\hline Rio Grande do Sul & 76,01 & 77,50 & 78,79 & 79,90 & 80,84 \\
\hline Centro-Oeste & 73,69 & 74,90 & 75,97 & 76,91 & 77,73 \\
\hline Mato Grosso do Sul & 73,80 & 75,28 & 76,53 & 77,58 & 78,45 \\
\hline Mato Grosso & 72,64 & 73,97 & 75,17 & 76,22 & 77,15 \\
\hline Goiás & 73,13 & 74,00 & 74,83 & 75,60 & 76,32 \\
\hline Distrito Federal & 76,34 & 77,85 & 79,08 & 80,06 & 80,83 \\
\hline
\end{tabular}

Fonte: elaboração dos autores com base em IBGE, 2013b.

Figura 4 - Esperança de vida ao nascer segundo unidades da federação. Brasil - 2010 e 2030

Brasil 2010

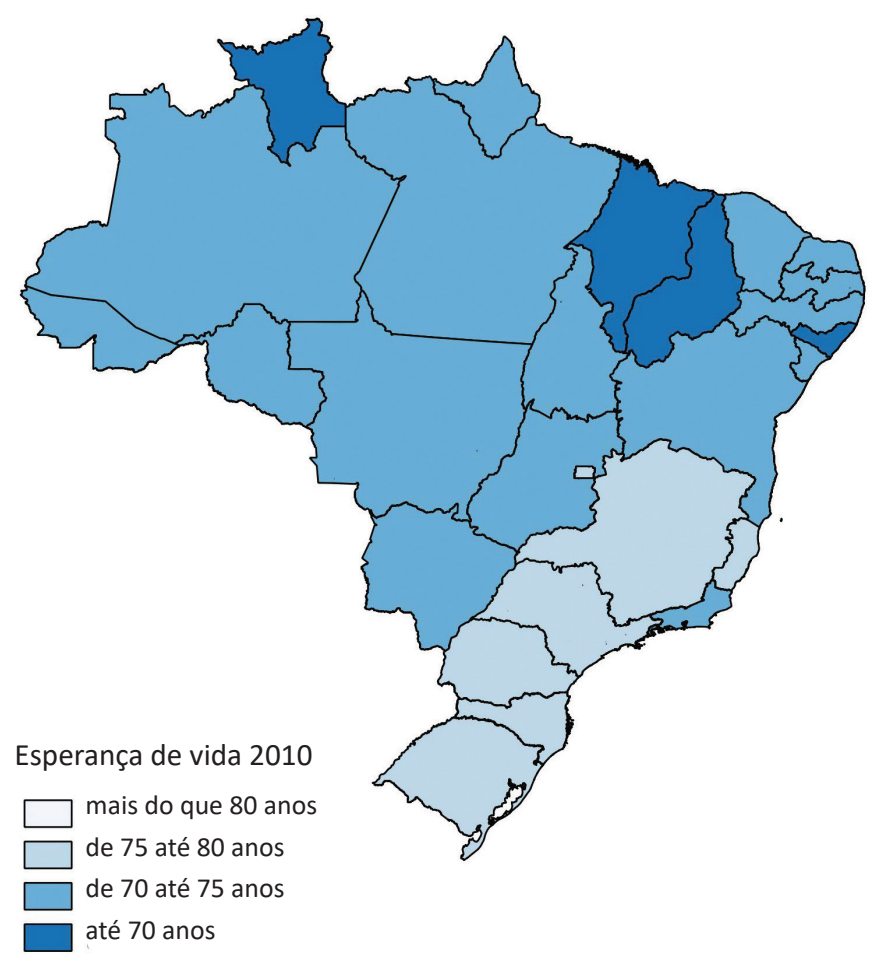

Brasil 2030

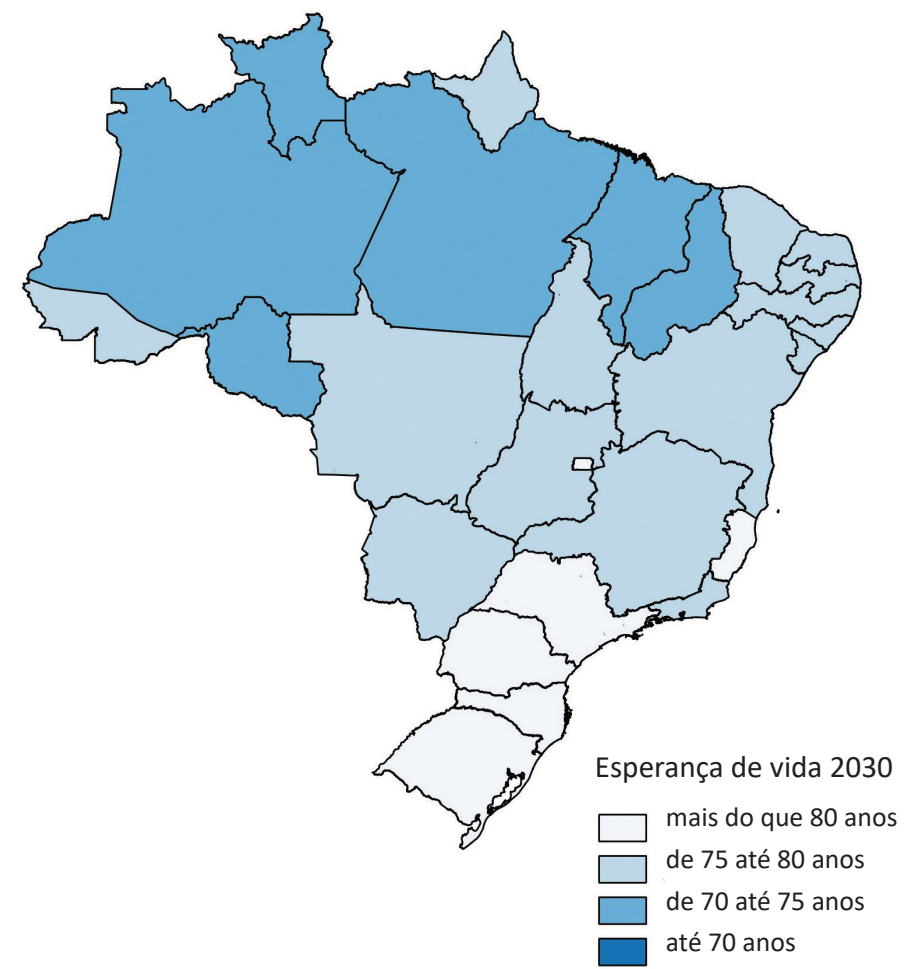

Fonte: elaboração dos autores com base em IBGE, 2013b. 
A Figura 4 mostra a evolução espacial do indicador entre 2010 e 2030 . Quando fazemos a comparação com outros países observamos que, no ponto de partida, algumas poucas UFs do Norte e do Nordeste encontravam-se ligeiramente abaixo da média mundial (70,1 anos), ao passo que as UFs do Sul, Sudeste e o Distrito Federal se acercavam de valores próximos à média dos países desenvolvidos (77,7 anos). Para 2030, espera-se que os estados do Sul, Espírito Santo, São Paulo e o Distrito Federal superem a média dos países desenvolvidos (80,4 anos) e que os demais estados apresentem valores acima do esperado para a média mundial (73,5 anos).

\section{Mortalidade infantil}

O Brasil assumiu como meta, no âmbito dos ODMs, que a TMI, no ano de 2015, seria de 15 óbitos infantis para cada 1.000 nascidos vivos, meta que para a média do país foi atingida em 2013, como já mencionado. Contudo, como podemos observar na Tabela 5 , muitas das UFs ainda estão longe de alcançar esse valor, particularmente aquelas localizadas nas regiões Norte e Nordeste, onde apenas em Roraima $(18,4)$, Tocantins $(19,4)$, Ceará $(19,7)$ e Pernambuco $(18,5)$ a TMI era menor que 20\%o. Os destaques negativos foram os estados do Maranhão (29,0\%o) e Alagoas (30,2\%0). Nesse quadro, a região Norte apenas alcançará o objetivo em 2023, ao passo que no Nordeste isto acontecerá um pouco antes, em 2019. A expectativa positiva para 2030 ficará por conta das UFs do Ceará e Pernambuco, cuja estimativa é de uma TMI de 9,8\% .

As UFs do Centro-Sul e o Distrito Federal já estavam abaixo da meta em 2010, o que deverá ser alcançado pela região Centro-Oeste como um todo dentro do prazo previsto, em 2015. Espera-se que, em 2030, apenas Mato Grosso (12,5\%) e Goiás (10,6\%o) experimentem taxas superiores a $10 \%$.

Comparando-se o indicador com o observado no cenário internacional, embora abaixo da TMI média mundial (37,0\%), em 2010 o Brasil estava muito distante dos países desenvolvidos que registravam, em média, taxas na ordem de 6\%o. A Figura 5 mostra que, em 2010, a maior parte das UFs apresentavam valores superiores a 20\%o (12 UFs) e entre 15 e 20\%o (7 UFs). Em 2030 nos afastaremos bastante da taxa média mundial $(26,0 \%$ ) e nos aproximaremos um pouco mais das taxas a serem experimentadas pelos países desenvolvidos (4,0\%), especialmente os estados do Centro-Sul, onde se espera que o indicador seja da ordem de 6,5\%. 
Tabela 5 - Taxa de mortalidade infantil, segundo Brasil, grandes regiões e unidades da federação 2010-2013

\begin{tabular}{|c|c|c|c|c|c|}
\hline \multirow{2}{*}{$\begin{array}{l}\text { Brasil, grandes regiões } \\
\text { e unidades da federação }\end{array}$} & \multicolumn{5}{|c|}{ Anos } \\
\hline & 2010 & 2015 & 2020 & 2025 & 2030 \\
\hline BRASIL & 17,22 & 13,82 & 11,56 & 10,04 & 9,01 \\
\hline Norte & 21,12 & 18,06 & 15,82 & 14,22 & 13,07 \\
\hline Rondônia & 22,75 & 20,38 & 18,43 & 16,81 & 15,47 \\
\hline Acre & 22,08 & 17,63 & 14,81 & 13,10 & 12,09 \\
\hline Amazonas & 22,20 & 18,77 & 16,26 & 14,45 & 13,18 \\
\hline Roraima & 18,37 & 17,39 & 16,49 & 15,64 & 14,84 \\
\hline Pará & 20,30 & 17,09 & 14,77 & 13,12 & 11,96 \\
\hline Amapá & 24,58 & 23,45 & 22,41 & 21,42 & 20,50 \\
\hline Tocantins & 19,39 & 16,32 & 14,11 & 12,53 & 11,43 \\
\hline Nordeste & 23,08 & 17,50 & 14,17 & 12,22 & 11,08 \\
\hline Maranhão & 29,02 & 22,37 & 17,81 & 14,81 & 12,88 \\
\hline Piauí & 23,45 & 19,72 & 16,98 & 14,89 & 13,30 \\
\hline Ceará & 19,68 & 15,07 & 12,31 & 10,70 & 9,77 \\
\hline Rio Grande do Norte & 20,60 & 15,34 & 12,68 & 11,38 & 10,74 \\
\hline Paraíba & 22,87 & 17,01 & 13,47 & 11,41 & 10,27 \\
\hline Pernambuco & 18,51 & 13,26 & 11,07 & 10,18 & 9,83 \\
\hline Alagoas & 30,22 & 20,86 & 15,56 & 12,78 & 11,40 \\
\hline Sergipe & 22,58 & 17,02 & 13,58 & 11,51 & 10,30 \\
\hline Bahia & 23,13 & 18,11 & 14,89 & 12,88 & 11,64 \\
\hline Sudeste & 13,02 & 10,74 & 9,05 & 7,81 & 6,89 \\
\hline Minas Gerais & 14,63 & 11,41 & 9,18 & 7,65 & 6,60 \\
\hline Espírito Santo & 11,97 & 9,19 & 7,52 & 6,53 & 5,94 \\
\hline Rio de Janeiro & 14,06 & 11,89 & 10,09 & 8,63 & 7,44 \\
\hline São Paulo & 11,98 & 10,16 & 8,77 & 7,71 & 6,91 \\
\hline Sul & 11,61 & 9,72 & 8,22 & 7,04 & 6,12 \\
\hline Paraná & 12,05 & 9,71 & 7,93 & 6,60 & 5,60 \\
\hline Santa Catarina & 11,20 & 9,49 & 8,11 & 7,00 & 6,12 \\
\hline Rio Grande do Sul & 11,39 & 9,88 & 8,62 & 7,56 & 6,69 \\
\hline Centro-Oeste & 16,99 & 14,76 & 12,95 & 11,50 & 10,34 \\
\hline Mato Grosso do Sul & 17,03 & 14,48 & 12,50 & 11,00 & 9,87 \\
\hline Mato Grosso & 19,52 & 17,30 & 15,40 & 13,80 & 12,46 \\
\hline Goiás & 17,71 & 15,35 & 13,41 & 11,84 & 10,58 \\
\hline Distrito Federal & 11,99 & 10,76 & 9,71 & 8,84 & 8,11 \\
\hline
\end{tabular}

Fonte: elaboração dos autores com base em IBGE, 2013b. 
Figura 5 - Taxa de mortalidade infantil segundo unidades da federação. Brasil - 2010-2013
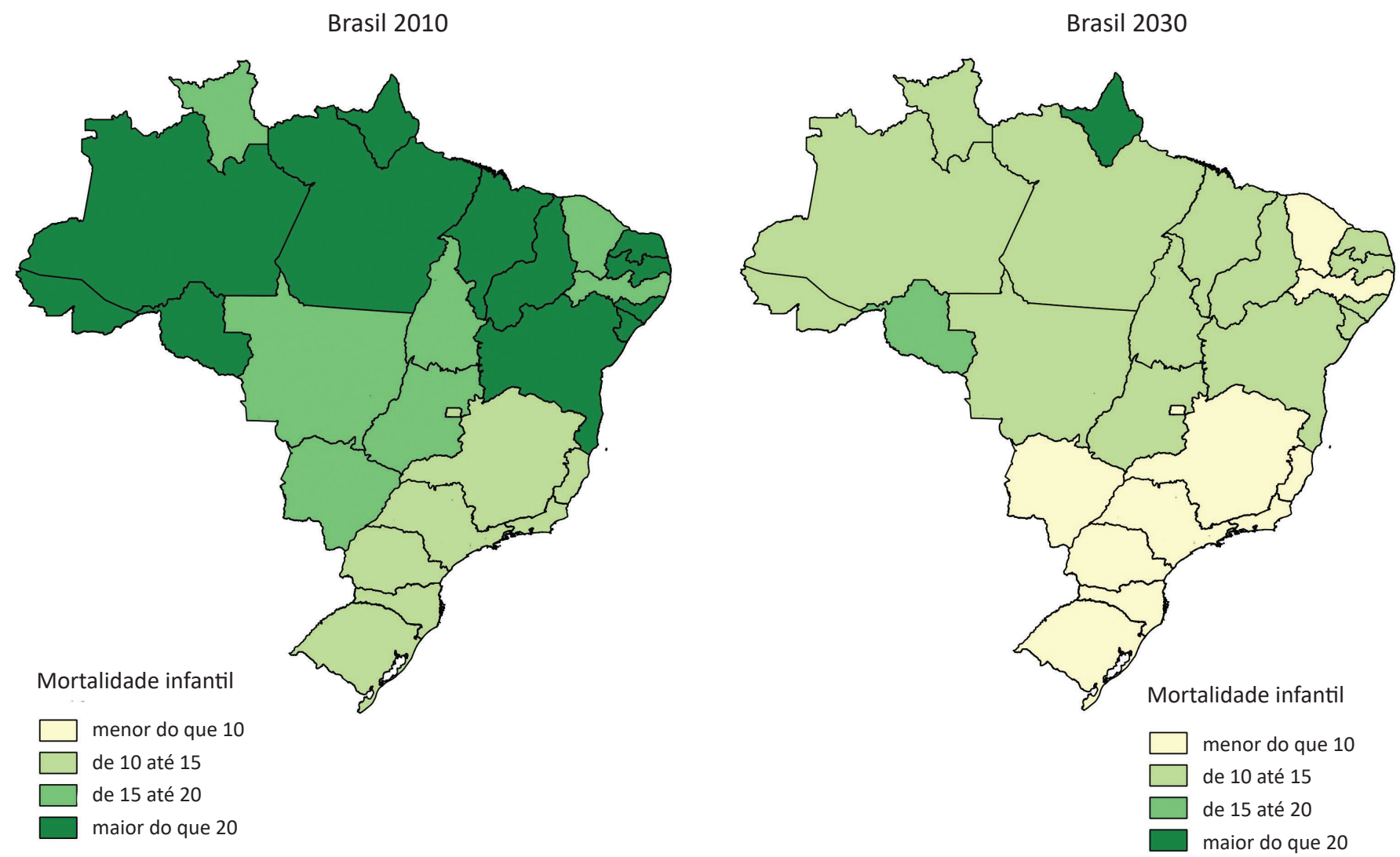

Fonte: elaboração dos autores com base em IBGE, 2013b.

\section{Mobilidade espacial da população}

A mobilidade espacial da população brasileira vem experimentando, a partir dos anos 1980, uma série de transformações, seja na escala interna, seja na internacional. No que tange aos deslocamentos internos, observamos, entre outros, os seguintes aspectos:

1) redução da atratividade migratória exercida pelo estado de São Paulo;

2) volatilidade da corrente principal no estado do Rio de Janeiro;

3) aumento da retenção de população na região Nordeste;

4) migração de retorno;

5) novos eixos de deslocamentos populacionais em direção às cidades médias no interior e nas periferias metropolitanas;

6) perda de importância nas UFs de atração e expulsão na escala das trocas interestaduais;

7) aumento da importância dos deslocamentos pendulares;

8) diminuição na participação relativa das pessoas que se deslocam de um município a outro. 
No que diz respeito às trocas internacionais, o Brasil, que, entre os anos 1930 e 1970, era considerado país fechado à migração, na década de 1980, com a crise econômica, passa a observar a saída expressiva de população para o exterior, sendo estimado que o saldo migratório nessa década fosse negativo em aproximadamente 1,5 milhão de pessoas (Carvalho, 1996; Oliveira et al., 1996). Embora sem números oficiais, imaginava-se que nos anos 1990 o quadro seguiu com perda populacional nas trocas internacionais, fenômeno que viria a ser revertido no final da década de 2000, em virtude da crise econômica mundial, que afetou de forma dramática os países desenvolvidos, em especial aqueles que serviam como principal destino da emigração brasileira (EUA, Japão, Espanha, Portugal, Itália). Os dados do Censo Demográfico de 2010 registraram não só o aumento no retorno de brasileiros, que representou a maior parcela das entradas vindas do exterior, como o acréscimo da chegada de estrangeiros. Além disso, as informações do Ministério do Trabalho e Emprego sinalizam, para os anos 2010, o aumento dos vistos de trabalho para estrangeiros, corroborando hipótese de inversão de tendência no cenário das migrações internacionais (Brasil, 2014).

Em relação aos movimentos internos, observa-se que a participação relativa das pessoas que se deslocam de um município a outro vem diminuindo desde os anos 1980, indicando uma menor mobilidade espacial da população. Na escala mais agregada, embora com fluxos menos volumosos, São Paulo continua atraindo um contingente expressivo de migrantes internos, e a região Nordeste permanece como principal espaço de expulsão de população. Apesar das cidades médias no interior e na periferia das metrópoles passarem a atrair um volume significativo da migração, ainda não superam em volume absoluto o número de migrantes que se dirigem aos grandes centros. Todavia, nas cidades médias, a componente migratória contribui com peso importante para o crescimento demográfico, sobretudo no dinamismo das cidades polos e seu entorno, como pode ser observado na Figura 6.

Para as UFs foram assumidas hipóteses segundo as quais não haverá alterações nos quadros econômicos, sociais e ambientais que possam acarretar mudanças substantivas no comportamento do fenômeno migratório nessas áreas para o período projetado (2010-2030), como pode ser observado na Tabela 6. Nesse sentido, na região Norte, Acre e Pará experimentarão saldos migratórios negativos no período, ao contrário dos demais estados, nos quais os saldos serão positivos.

A região Nordeste continuaria sendo, no período, a única com migração líquida negativa, isso em decorrência dos resultados esperados para o Maranhão, Piauí, Ceará, Paraíba, Pernambuco, Alagoas e Bahia. Já os estados do Rio Grande do Norte e Sergipe seguiriam atraindo população.

Minas Gerais será o único estado da região Sudeste com perda populacional nas trocas migratórias, resultado que deverá ser determinado tanto pela migração interna quanto internacional. Espírito Santo e Rio de Janeiro experimentariam saldos migratórios positivos pouco expressivos, enquanto em São Paulo o saldo será mais expressivo, embora com valores bem menores do que os das décadas passadas. 
Figura 6 - Taxa líquida de migração segundo municípios. Brasil - 2010

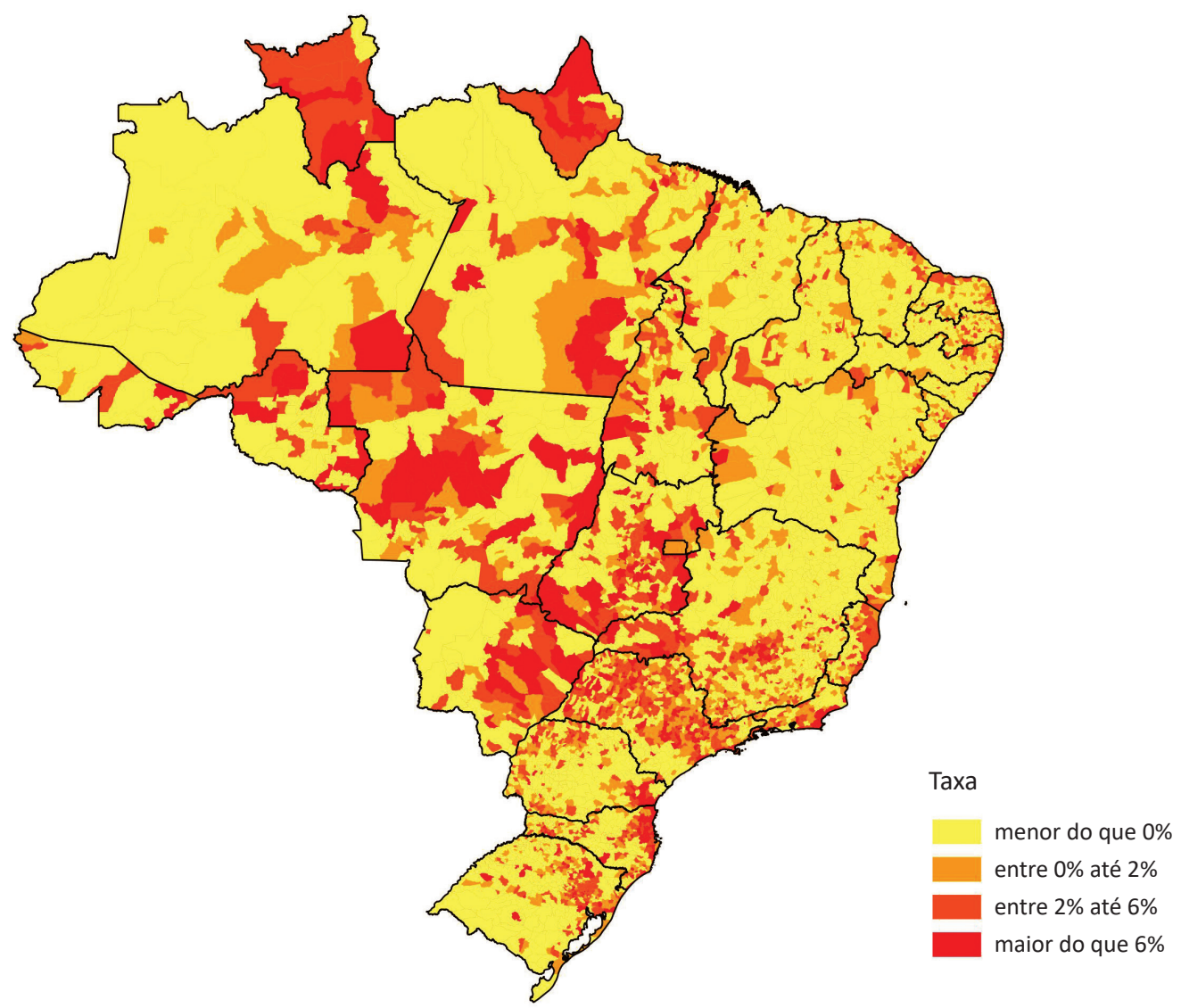

Fonte: elaboração dos autores com base IBGE, 2014c.

A região Sul, apesar de apresentar dois estados com perda líquida migratória, permanecerá atraindo mais do que expulsando migrantes, fruto do desempenho a ser observado em Santa Catarina. O Paraná perderá população na maior parte do tempo, mas passará por um período em que os saldos serão positivos em decorrência dos ganhos com a imigração internacional. Já para o Rio Grande do Sul a expectativa é de saldo negativo para todo o período projetado.

No Centro-Oeste o dinamismo do agronegócio e do centro administrativo de Brasília fará com que a região siga ganhando população nas trocas migratórias. Mato Grosso do Sul e Mato Grosso apresentarão ganhos menos expressivos e Goiás, além de saldos positivos nas trocas internas, também ganhará população com a migração internacional. O Distrito Federal continuará atraindo, no plano interno, um contingente significativo de migrantes.

Em suma, no plano das trocas internas, apesar das importantes transformações observadas no fenômeno, em valores absolutos, São Paulo segue como o principal polo de atração, e o Nordeste, 
a região de onde partem os principais fluxos migratórios, ressaltando-se o aumento da importância relativa das cidades médias. No cenário internacional, o quadro é de incerteza, sobretudo pela volatilidade na dinâmica desses movimentos, em grande medida determinada pelas assimetrias no comportamento da economia mundial.

Tabela 6 - Saldo migratório, segundo Brasil e unidades da federação - 2010-2013

\begin{tabular}{|c|c|c|c|c|c|}
\hline \multirow{2}{*}{$\begin{array}{c}\text { Brasil e } \\
\text { unidades da federação }\end{array}$} & \multicolumn{5}{|c|}{ Anos } \\
\hline & 2010 & 2015 & 2020 & 2025 & 2030 \\
\hline BRASIL & 0 & 3.982 & 8.304 & 5.389 & 4.415 \\
\hline Rondônia & 1.865 & 1.799 & 1.673 & 1.582 & 1.422 \\
\hline Acre & -119 & -123 & -122 & -129 & -128 \\
\hline Amazonas & 3.091 & 3.528 & 3.904 & 3.660 & 3.382 \\
\hline Roraima & 1.025 & 1.023 & 1.018 & 975 & 900 \\
\hline Pará & -7.165 & -7.912 & -8.383 & -7.669 & -6.853 \\
\hline Amapá & 2.986 & 3.180 & 3.337 & 3.394 & 3.374 \\
\hline Tocantins & 667 & 706 & 723 & 766 & 817 \\
\hline Maranhão & -34.274 & -34.387 & -34.201 & -32.254 & -29.583 \\
\hline Piauí & -17.333 & -16.389 & -15.612 & -14.376 & -12.842 \\
\hline Ceará & -18.034 & -17.623 & -16.740 & -15.511 & -14.235 \\
\hline Rio Grande do Norte & 2.652 & 2.653 & 2.602 & 2.591 & 2.567 \\
\hline Paraíba & -4.612 & -4.227 & -4.053 & -3.820 & -3.428 \\
\hline Pernambuco & -12.692 & -13.150 & -13.368 & -12.353 & -11.119 \\
\hline Alagoas & -16.613 & -16.294 & -15.651 & -14.623 & -13.413 \\
\hline Sergipe & 2.076 & 2.105 & 2.112 & 2.151 & 2.178 \\
\hline Bahia & -52.275 & -50.549 & -48.296 & -43.869 & -39.561 \\
\hline Minas Gerais & -4.652 & -8.314 & -10.938 & -9.790 & -8.598 \\
\hline Espírito Santo & 12.938 & 12.075 & 11.221 & 11.077 & 10.805 \\
\hline Rio de Janeiro & 2.311 & 2.767 & 2.708 & 1.155 & -25 \\
\hline São Paulo & 42.193 & 44.416 & 46.826 & 39.379 & 32.195 \\
\hline Paraná & -3.879 & -1.091 & 1.419 & -524 & -1.848 \\
\hline Santa Catarina & 38.793 & 38.690 & 38.236 & 36.496 & 34.660 \\
\hline Rio Grande do Sul & -19.136 & -17.911 & -16.597 & -16.064 & -15.237 \\
\hline Mato Grosso do Sul & 5.011 & 5.511 & 5.895 & 4.865 & 3.960 \\
\hline Mato Grosso & 7.636 & 7.108 & 6.551 & 5.950 & 5.268 \\
\hline Goiás & 36.819 & 34.941 & 33.005 & 33.089 & 32.475 \\
\hline Distrito Federal & 30.723 & 31.450 & 31.035 & 29.239 & 27.279 \\
\hline
\end{tabular}

Fonte: elaboração dos autores com base em IBGE, 2013b. 


\section{A Oferta e o Acesso aos Serviços de Saúde}

\section{A centralidade dos espaços em saúde}

A centralidade em saúde foi identificada mediante associação de dois indicadores: o de complexidade nos centros localizados nas áreas imediatas de articulação urbano-regional e o de tamanho do setor, avaliado pelo volume das internações hospitalares. O de complexidade foi construído com base na existência de equipamentos em saúde e especialidades nas cidades, para determinar o grau de atendimento disponível. O indicador de tamanho utilizado foi o número de internações hospitalares financiadas pelo SUS em 2012. Os dois indicadores correspondem ao conjunto de informações disponíveis na publicação Regiões de Influência das Cidades - 2007 (IBGE, 2008), atualizada para 2009 e com adaptações nos procedimentos. Cabe observar que tal publicação fornece também a hierarquia dos centros urbanos do país, que foi utilizada como mais uma fonte de informação e anexada a esse estudo.

A construção do indicador de nível de complexidade levou em conta 11 tipos de equipamentos e 26 especialidades informadas pelos estabelecimentos. Essas medidas são denominadas indicadores de estoques e representam a capacidade de prestação de serviços de saúde de um centro urbano. Cabe observar que os valores de estoques também são indicativos de processos espaciais, concretizados ou em curso, resultantes de políticas de saúde empreendidas até então. A existência dos instrumentos e das especialidades determina certo grau de disponibilidade de acesso à saúde e, conforme a combinação dos atributos, a complexidade disponível nos centros.

Uma vez selecionados os equipamentos e especialidades que compõem o indicador, direcionou-se o tratamento dos dados para a construção de duas matrizes espaciais como método de apreensão do território. As matrizes possuem os municípios nas linhas e os atributos nas colunas, e a junção das linhas e das colunas forma células com valores em uma localização particular, que, uma vez contabilizados e classificados, permitem assimilar as formas de organização espacial de um dado território.

$\mathrm{Na}$ construção dos indicadores, registrou-se o número de equipamentos e de especialidades médicas que serviram de referência para se obter duas tabelas com a presença dos atributos. Assim, se um município possuísse mais de um equipamento para hemodiálise ou nefrologista, apenas a existência do equipamento ou a especialidade foi registrada.

Em seguida, a presença do equipamento ou da especialidade foi totalizada de forma que se verificou que apenas 60 municípios dispõem da bomba de cobalto, enquanto aparelhos de eletrocardiógrafo podem ser encontrados em 3.680 municípios. Quanto às especialidades, a videolaparoscopia pode ser encontrada em apenas 27 municípios, enquanto clínica médica aparece em 3.626, indicando graus de complexidades variadas entre os municípios. Os Quadros 1 e 2 ilustram a frequência dos equipamentos e especialidades selecionados e trazem a hierarquia definida para cada atributo. 
Quadro1 - Frequência e hierarquia dos equipamentos

\begin{tabular}{|l|c|c|}
\hline \multicolumn{1}{|c|}{ Equipamentos } & Total de municípios & Classes de hierarquia \\
\hline Bomba de cobalto & 60 & 1 \\
\hline Circulação extracorpórea & 121 & 2 \\
\hline Ressonância magnética & 164 & 2 \\
\hline Mamografia com estereotaxia & 175 & 2 \\
\hline Hemodiálise & 359 & 3 \\
\hline Tomógrafo computadorizado & 426 & 3 \\
\hline Eletroencefalógrafo & 552 & 3 \\
\hline Mamógrafo com comando simples & 647 & 3 \\
\hline Ultrassom com doppler colorido & 1.003 & 4 \\
\hline Ultrassom com ecógrafo & 2.025 & 4 \\
\hline Eletrocardiógrafo & 3.680 & 5 \\
\hline
\end{tabular}

Fonte: elaboração dos autores com base em IBGE, 2010.

Quadro 2 - Frequência e hierarquia das especialidades

\begin{tabular}{|l|c|c|}
\hline \multicolumn{1}{r}{ Especialidades } & Total de municípios & Classe de hierarquia \\
\hline Videolaparoscopia & 27 & 1 \\
\hline Quimioterapia & 33 & 1 \\
\hline Medicina nuclear & 92 & 1 \\
\hline Hemodinâmica & 93 & 1 \\
\hline Neurocirurgia & 190 & 2 \\
\hline Hematologia & 210 & 2 \\
\hline Oncologia & 213 & 2 \\
\hline Proctologia & 217 & 2 \\
\hline Reumatologia & 222 & 2 \\
\hline Nefrologia & 331 & 3 \\
\hline Cirurgia plástica & 352 & 3 \\
\hline Pneumologia/Tisiologia & 381 & 3 \\
\hline Angiologia & 433 & 3 \\
\hline Endocrinologia & 573 & 3 \\
\hline Neurologia & 884 & 4 \\
\hline Oftalmologia & 1.082 & 4 \\
\hline Ortopedia e traumatologia & 1.727 & 4 \\
\hline Cirurgia geral & 1.766 & 4 \\
\hline Cardiologia & 1.981 & 4 \\
\hline Obstetrícia & 2.171 & 5 \\
\hline Análises clínicas & 2.813 & 5 \\
\hline
\end{tabular}


Quadro 2 - Frequência e hierarquia das especialidades (cont.)

\begin{tabular}{|c|c|c|}
\hline Especialidades & Total de municípios & Classe de hierarquia \\
\hline Pediatria & 2.995 & 5 \\
\hline Ginecologia & 3.298 & 5 \\
\hline Clínica médica & 3.626 & 5 \\
\hline
\end{tabular}

Fonte: elaboração dos autores com base em IBGE, 2010.

Com base na frequência da distribuição dos equipamentos em condições de uso pelos municípios, os 11 selecionados para compor os indicadores do nível de complexidade em saúde foram alocados em cinco classes. Assim, todos os 3.680 municípios pertenciam à classe 5 , definida pela presença do eletrocardiógrafo, a partir da qual a inclusão é contínua. Para serem classificados nas classes superiores, os municípios teriam que possuir pelo menos um dos equipamentos de cada classe até a primeira classe, em que a presença de bomba de cobalto posicionou, na maior hierarquia, os municípios com esse equipamento.

Procedimento semelhante foi utilizado para classificar as cidades segundo as especialidades disponíveis nos estabelecimentos de saúde ali situados, com cinco especialidades por classe. Os 3.626 municípios com especialidades foram alocados às classes quando dispunham de pelo menos três das especialidades que as definem. Aqueles que não tinham equipamentos ou especialidades receberam a classificação 0 (zero).

Em seguida, as duas classificações foram combinadas com o objetivo de obterem-se os níveis de complexidade (classe complexidade 1) dos centros. A combinação das duas classificações serve para

contornar questões ligadas à possibilidade de um município ter o equipamento disponível sem a presença dos profissionais necessários para sua operação, bem como a de existir o atendimento em determinada especialidade, mas sem ser registrado, por não constituir a principal atividade do estabelecimento. (IBGE, 2008: 136)

A classificação resultou numa hierarquia em seis níveis. Todos os municípios que apresentaram classificação em apenas um dos eixos, ou seja, sem equipamentos ou sem especialidades (resultado 0) formam os municípios classificados no sexto nível.

O número de internações hospitalares pagas pelo SUS em 2012 foi outra informação utilizada para classificar os centros em seis classes. Somente foram classificados os centros que possuíam mais de $0,01 \%$ do volume de internações no total do Brasil, o que significa 92,3\% do total de internações.

A combinação dos indicadores de complexidade e tamanho resultou no índice de centralidade que possui uma escala de 0 (zero) a 6 (seis), sendo 0 a ausência do atributo e, a partir de 1 até 6 , o nível do centro baixa na centralidade em saúde. Os centros que apresentaram 0 num dos indicadores e valor diferente no outro receberam a nota 6 e, na combinação dos índices de complexidade e tamanho, prevaleceu a classe mais alta em que o centro foi classificado; assim, se um centro estava na classe 2 de complexidade e 4 em tamanho, sua centralidade foi 4. 
Outro indicador utilizado refere-se ao número de leitos hospitalares por 1.000 habitantes (IBGE, 2010), que mede a oferta física de leitos hospitalares em relação à população residente nas áreas imediatas de articulação urbano-regional (Quadro 3). Esse indicador pode ser utilizado como uma proxy para a demanda em atendimento hospitalar, uma vez que o número de leitos deve atender as necessidades da população de uma determinada região.

De 1990 a 2009 a média do número de leitos por 1.000 habitantes no país diminuiu de 3,71 para 2,46. De acordo com o Ministério da Saúde, esse comportamento vem ocorrendo em outros países e é resultado não só da ampliação de atendimento ambulatorial, mas também da possibilidade de tratamentos - que, graças às inovações tecnológicas, reduzem a necessidade de internações, dentre eles alguns tratamentos de câncer - além dos investimentos e melhor qualificação na rede pública.

Segundo o estudo feito pela CIA World Factbook, ${ }^{2}$ referente ao número de leitos por habitantes, dos 181 países pesquisados o Japão figura em primeiro lugar, com 13,7/1.000 habitantes; França em

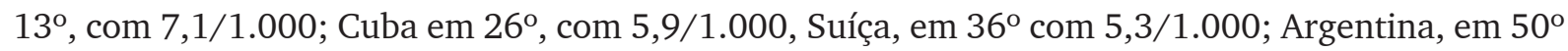
lugar, com 4,0/1.000; Estados Unidos, em 69 ${ }^{\circ}$, com 3,1/1.000; Uruguai, em $77^{\circ}$, com 2,9/1.000 e o Brasil, em $89^{\circ}$, com 2,4/1.000. Esses valores, que não estão correlacionados ao desempenho econômico dos países, indicam, possivelmente, a importância das políticas para o setor empreendidas nas diferentes nações, que envolvem o acesso e a eficiência dos serviços disponibilizados à população.

Ainda que o Brasil apresente grande diversidade regional na prestação de serviços de saúde, existe, da parte de órgãos oficiais como o Ministério da Saúde, a Organização Mundial de Saúde (OMS) e a Organização Pan-Americana de Saúde (Opas), a recomendação de adoção de um intervalo considerado razoável de disponibilidade de leitos para internações, que varia entre 2,5 a 3,0 leitos por 1.000 habitantes. $^{3}$

Quadro 3 - Leitos por 1.333 habitantes. Brasil - 1990-2009

\begin{tabular}{|c|c|}
\hline Período & Leitos \\
\hline 1990 & 3,71 \\
\hline 1992 & 3,66 \\
\hline 1999 & 2,96 \\
\hline 2002 & 2,70 \\
\hline 2005 & 2,41 \\
\hline 2009 & 2,46 \\
\hline
\end{tabular}

Fonte: elaboração dos autores com base em IBGE, 2010.

Com base nas projeções de população, foi possível generalizar os valores das taxas de crescimento populacional e obter áreas de maior e menor dinamismo populacional no país.

\footnotetext{
${ }^{2}$ Disponível em: <www.indexmundi.com/g/r.aspx?c=br\&v=2227\&l=pt $>$. Acesso em: jan. 2014.

${ }^{3}$ Parâmetros para programação das ações básicas de saúde MS. Disponível em: <www.paho.org/bra/index. php?option=com_docman>. Acesso em: jan. 2014.
} 
Cabe observar que, na pesquisa Regiões de Influência das Cidades - 2007 (IBGE, 2008), a hierarquia urbana das cidades que apresentam grandes aglomerações urbanas é formada por um conjunto de municípios denominado áreas de concentração de população (ACPs). As ACPs configuram-se como espaços diferenciados, onde os fenômenos urbanos são intensos, resultando em modelos territoriais mais adequados às novas tendências da urbanização (Castello Branco, 2006). São múltiplas redes que se apoiam nesses centros privilegiados, atravessados por fluxos de todos os tipos, tais como: pessoas, informações, produtos, entre outros. A Figura 7 mostra a distribuição desse recorte territorial no país.

Figura 7 - Áreas de concentração da população - 2009

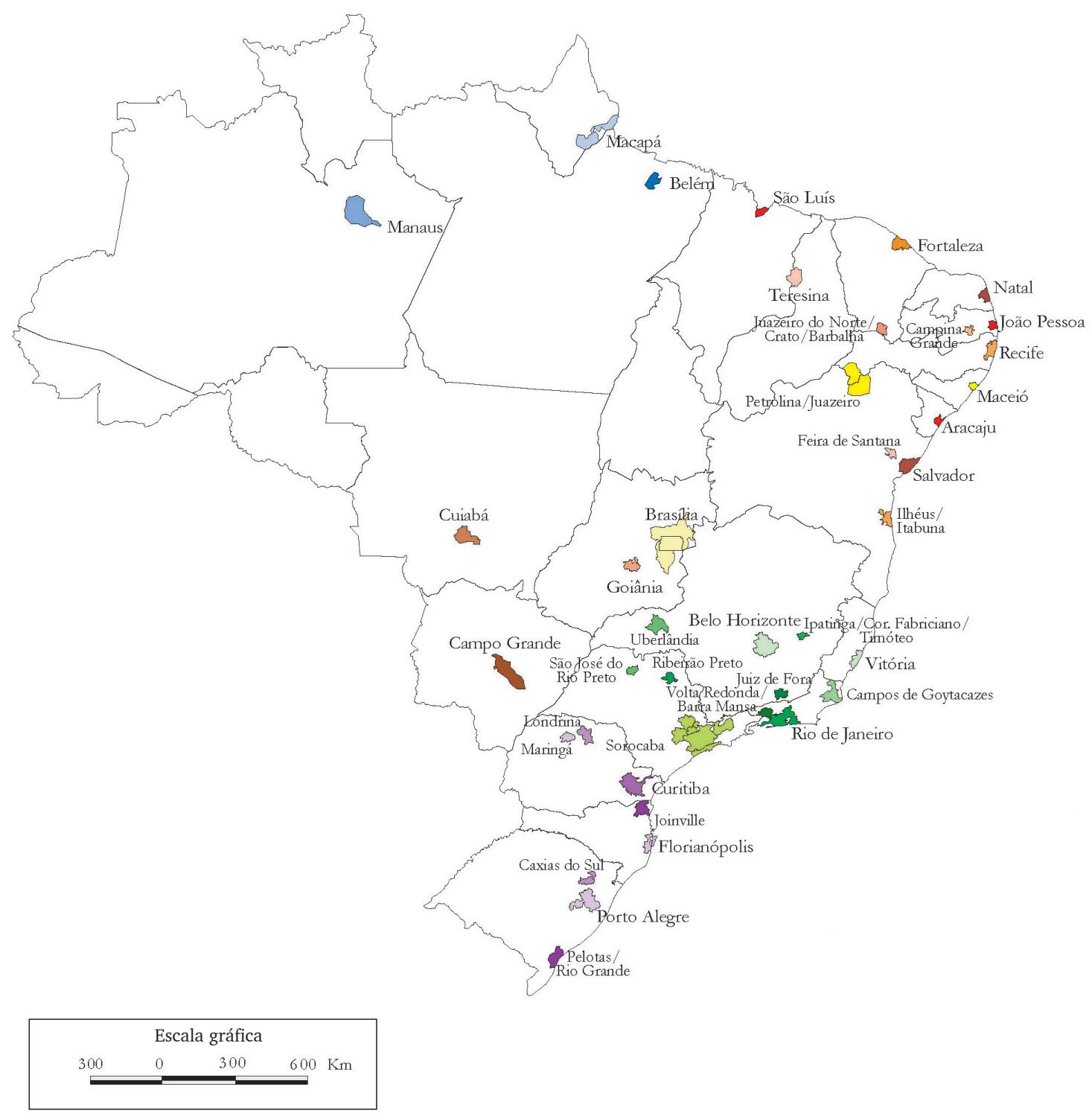

Fonte: elaboração dos autores com base em dados do IBGE - Coordenação de Geografia. 


\section{Resultados}

A incorporação das regiões de articulação imediata, seus polos e os outros centros que compõem cada região são elementos fundamentais para integrar os resultados parciais - classes de especialidade e classe de equipamentos e classe de tamanho, número de leitos por 1.000 habitantes, áreas de maior e menor dinamismo populacional, a centralidade em saúde, associada à hierarquia dos centros urbanos - e assim municiar o processo de tomada de decisão, levando em consideração a localização e as características de cada polo. Tal arquitetura identifica uma rede urbana com funcionalidade e complementaridade entre os centros, vantagens locacionais capazes de imprimir a diferenciação a partir do nível mais alto da hierarquia para os centros dispostos nos níveis inferiores.

Conforme já mencionado, a centralidade resultou em um quadro síntese (Quadro 4) com os níveis de complexidade obtidos a partir da combinação das classes de complexidade e de volume. Num conjunto de 5.567 municípios analisados, 1.132 não possuem centralidade; apenas um, São Paulo, apresenta centralidade máxima, igual a 1; e 3.997 foram classificados com a mais baixa centralidade, que corresponde à centralidade 6 .

Os valores no Quadro 4 ilustram os padrões espaciais de distribuição de bens e serviços em saúde vigentes nas regiões imediatas de articulação urbana e revelam a forte concentração do setor. No tocante à complexidade, apenas 31 centros pesquisados possuem centralidade nas classes de 1 a 3. Os três primeiros níveis de centralidade em saúde caracterizam centros que atuam num nível de atendimento mais complexo, pois foram os melhores classificados em termos de presença de equipamentos e especialidades de maior hierarquia (Quadros 1 e 2), assim como têm os mais altos valores nas internações hospitalares.

Quadro 4 - Níveis de centralidade segundo oferta de serviços de saúde: complexidade e tamanho. Brasil - 2009-2012

\begin{tabular}{|c|c|c|c|c|c|c|c|c|c|c|}
\hline \multirow[t]{2}{*}{$\begin{array}{l}\text { Níveis de } \\
\text { centralidade }\end{array}$} & \multirow[t]{2}{*}{$\begin{array}{l}\text { Número de } \\
\text { municípios }\end{array}$} & \multicolumn{7}{|c|}{ Classes de complexidade } & \multirow{2}{*}{$\begin{array}{c}\text { Classe de } \\
\text { volume }\end{array}$} & \multirow{2}{*}{$\begin{array}{l}\text { Número de } \\
\text { internações } \\
\text { SUS }\end{array}$} \\
\hline & & 1 & 2 & 3 & 4 & 5 & 6 & 0 & & \\
\hline 1 & 1 & 1 & & & & & & & 1 & 676.996 \\
\hline 2 & 10 & 4 & 6 & & & & & & 2 & 256.354 \\
\hline 3 & 20 & 3 & 17 & & & & & & 3 & 185.415 \\
\hline 4 & 64 & 2 & 44 & 13 & 5 & & & & 4 & 18.071 \\
\hline 5 & 342 & 1 & 44 & 122 & 151 & 24 & & & 5 & 1.674 \\
\hline 6 & 10 & & & & & & 9 & 1 & 5 & 1.674 \\
\hline 6 & 913 & & 2 & 41 & 401 & 321 & 126 & 22 & 6 & 1.232 \\
\hline 6 & 3.074 & & 1 & 2 & 257 & 1.339 & 1.475 & & 0 & 0 \\
\hline 0 & 1.132 & & & & & & & 1.132 & 0 & \\
\hline
\end{tabular}

Fonte: elaboração dos autores. 
Ao examinar os resultados parciais das classificações, constata-se que, apesar de poucos municípios possuírem o equipamento de bomba de cobalto, ele está presente em quase todos os municípios com centralidade entre 1 e 3 . O número de internações hospitalares, por sua vez, foi determinante para a definição da centralidade, uma vez que muitos centros com níveis de complexidade média e alta não apresentaram o mesmo resultado na capacidade de internações hospitalares.

Apenas São Paulo alcançou a mais alta centralidade, de nível 1, tanto na complexidade como no volume das internações. Na classe 2 de centralidade podem ser encontrados centros com classificação 1 e 2, em complexidade de equipamento e de especialidade e nível 2 em volume das internações, classificando dez centros. O $3^{\circ}$ nível tem o dobro de centros, vinte ao todo, classificados segundo uma combinação de classes de complexidade 1 e 2 e de volume 3.

As classes de centralidade 2 e 3 qualificam polos em regiões imediatas com hierarquias urbanas que variam de metrópoles a capitais regionais, como Recife (PE), Belo Horizonte (MG), Rio de Janeiro (RJ), Curitiba (PR), Porto Alegre (RS) e Brasília (DF) no $2^{\circ}$ nível, e Belém (PA) Natal (RN), Maceió (AL), Vitória (ES), Sorocaba (SP) e Londrina (PR) no $3^{\circ}$ nível, entre outras. São centros que tradicionalmente já atraem fortemente pessoas que procuram serviços de saúde dos mais sofisticados aos mais simples.

A presença geográfica dos centros com centralidade 4 é maior nas regiões Nordeste e Sudeste, onde se localizam, aproximadamente, $70 \%$ dos centros, caindo, sensivelmente, para as regiões Norte, Sul e Centro-Oeste. Na região Norte, apenas Manaus (AM) e Belém (PA) possuem centralidade 2 e 3, respectivamente. Na região Sul, Curitiba (PR) e Porto Alegre possuem centralidade 2 e Londrina, 3 (Quadro 4). O resultado da pequena presença de centros nos níveis mais altos de centralidade em saúde reflete o processo de macrourbanização brasileiro, em que 49 aglomerações urbanas abrigam quase 50\% dos habitantes urbanos do país e concentram $65 \%$ do Produto Interno Bruto (PIB) nacional.

O $4^{\circ}$ nível de centralidade reúne 64 centros onde predominam condições de atendimento em saúde de média complexidade, nos quais se constata a presença de centros com hierarquias de capitais regionais e centros sub-regionais, a exemplo de Porto Velho (RO), Rio Branco (AC), Boa Vista (RR), Santarém (PA), Palmas (TO), Imperatriz (MA), as ACPs de Macapá (AP), Petrolina-Juazeiro (PE/BA), Ilhéus-Itabuna (BA), Ipatinga-Coronel Fabriciano (MG), Campos dos Goytacazes (RJ), Florianópolis e Joinville (SC) e apenas um centro de zona, que classifica a ACP de Jundiaí (SP), além de alguns centros que conformam ACPs.

A centralidade no $4^{\circ}$ nível já aparece mais representada em centros regionais longamente estabelecidos, conforme os exemplos citados, e resulta da combinação de centros classificados entre a $1^{\mathrm{a}}$ e a $4^{\mathrm{a}}$ classe de complexidade e a $4^{\mathrm{a}}$ classe em volume de internações, uma vez que na definição de centralidade predomina, na combinação, a classe de valor mais elevado. A presença desses centros guarda vinculações com o passado, quando o quadro da economia brasileira e a pouca acessibilidade, devido à precariedade dos transportes, fizeram surgir centros de hierarquia intermediária no sistema urbano, em particular nas regiões Nordeste, Sudeste e Sul. Mais recentemente, no século XX, o modelo de ocupação e incorporação do território nas regiões Norte e Centro-Oeste originou redes urbanas 
com pouca densidade, de forma que na centralidade em saúde, em nível 4, aparecem oito cidades na região Norte e apenas uma na Centro-Oeste, que são: Porto Velho (RO), Rio Branco (AC), Boa Vista (RR), Ananindeua e Santarém (PA), Macapá (AP), Araguaína e Palmas (TO) e Anápolis (GO).

O Quadro 4 dá uma ideia de como os níveis de centralidade 5 e 6 e o 0 (sem centralidade) retratam uma estrutura em saúde com lacunas nos escalões urbanos mais baixos que, em certa medida, reproduzem o sistema urbano brasileiro. Se o nível 4 de centralidade for considerado um escalão intermediário no atendimento a serviços de saúde, pode-se afirmar que são numericamente poucos em um país com as dimensões do Brasil e com distribuição desigual no território. Os níveis 5 e 6, de menor complexidade, por exemplo, são formados por diversas classes de complexidade, de 1 até 0 , demonstrando desequilíbrios agudos na distribuição de serviços de saúde e com combinações com as classes de volume que classificam grande parte dos centros urbanos no nível 6.

São 342 centros classificados na $5^{\mathrm{a}}$ classe de centralidade em saúde, com condições de atender casos de complexidade de média para baixa. Do total de centros nesta classe, 223 são polos de regiões imediatas e, neste escalão, a presença de eletrocardiógrafo, entre outros instrumentos, e de especializações com patamar de complexidade em obstetrícia, análises clínicas, pediatria, ginecologia e clínica médica classificam os centros.

Os equipamentos e especialidades mais frequentes estão disponíveis nos centros urbanos com centralidade 6, que são centros de menor porte e complexidade baixa e estão presentes em quase todo o território nacional, totalizando 3.997 centros em que parte significativa não possui internações ou esse valor não ultrapassa o patamar de 0,01\% das internações. No nível de centralidade 6 ocorre, também, a desigualdade na distribuição geográfica do fornecimento de serviços de saúde, uma vez que as regiões Nordeste, Sudeste e Sul contabilizam inúmeros centros neste patamar, enquanto nas regiões Norte e Centro-Oeste eles representam 14,0\% no total, são reduzidos e classificam inúmeros polos de regiões imediatas.

Cabe mencionar que 1.132 centros não possuem centralidade, uma vez que não registraram a presença de equipamentos e especialidades, assim como internações hospitalares. A lógica da oferta de bens e serviços é que a população de municípios com baixa centralidade ou sem centralidade se desloque para municípios com mais alta centralidade quando necessitam de serviços de maior complexidade.

Tal esquema, de busca por centros de hierarquia superior para atendimento em procedimentos de mais alta complexidade, parece razoável quando o sistema urbano se configura mais bem distribuído hierarquicamente na sua geografia. Entretanto, no caso brasileiro, redunda em atendimento desequilibrado, com concentração em poucos centros nos níveis de alta centralidade, que exercem forte polarização em suas áreas, enquanto outras áreas são precárias no atendimento a serviços em saúde.

À guisa de exemplo, pode-se citar a presença de numerosos centros com centralidade 6 e sem centralidade localizados em ACPs de São Paulo (SP), Recife (PE), Belo Horizonte (MG), Porto Alegre (RS), Rio de Janeiro (RJ), entre outras, que reúnem, em cada uma, inúmeros municípios. Quanto à precariedade nos serviços, Oliveira, Carvalho e Travassos afirmam que nas redes de alta 
complexidade, onde poucos centros têm capacidade de atendimento hospitalar, o atendimento é limitado pela disponibilidade e capacidade das pessoas para deslocar-se: "apenas $3 \%$ dos pacientes internados para cirurgia cardíaca residiam em municípios situados a mais de $60 \mathrm{~km}$ do centro em que se internaram e nestes municípios concentram-se cerca de 40,0\% da população brasileira" (Oliveira, Carvalho \& Travassos, 2004: 399).

A Figura 8 sintetiza a distribuição dos centros, segundo as classes de centralidade, variando do $1^{\circ}$ nível ao $6^{\circ}$ e a hierarquia urbana até os centros de zona (IBGE, 2008). Observa-se que as regiões imediatas de articulação urbana apresentam, cada uma delas, um polo de maior hierarquia que comanda e articula a sua região e um ou mais centros subordinados a esse polo, dando origem a formas espaciais organizadas segundo redes de atendimento imediato no setor Saúde.

As regiões imediatas, que recortam a Figura 8, têm ligações que refletem a acessibilidade e a capacidade de atender demandas de amplitude espacial mais restritas, em redes comandadas por centros desde metrópoles até os de menor hierarquia, como os centros de zona e em todos os níveis de centralidade em saúde. A rede urbana, com nós que apoiam as diversas atividades, gera fluxos variados mediante as novas tecnologias. Essa arquitetura permite identificar a funcionalidade dos centros e a complementaridade entre eles e, consequentemente, as vantagens locacionais que imprimem a diferenciação a partir do nível mais alto da hierarquia para os centros dispostos nos níveis inferiores e, nesse contexto, estabelecer intervenções para aprimorar a rede de saúde.

Quanto à dinâmica populacional, a Figura 9 desenha, para 2033, três grandes tendências no comportamento populacional, mantendo-se, sobretudo, as condições atuais no que tange aos aspectos econômicos, sociais e ambientais: as áreas de estabilidade, as de maior atração e as com perda populacional. As áreas de estabilidade estarão presentes em grande parte do território nacional e ocuparão quase toda a porção leste do país. Trata-se da parte mais densamente povoada, cuja estabilidade se amplia, uma vez que o ritmo de crescimento populacional tende a diminuir em decorrência do comportamento das taxas vitais. O novo cenário indica também a presença de uma faixa de estabilidade que divide as áreas de atração populacional e se estende do Pará até o Mato Grosso do Sul.

As áreas de atração ocupam grande parte das regiões Norte e Centro-Oeste, ocorrem nas grandes aglomerações urbanas e no litoral e mantêm um eixo de crescimento nas divisas entre as regiões Centro-Oeste e Sudeste, ao longo da rodovia Belém-Brasília, avançando em áreas da Bahia, Maranhão e Piauí.

De maneira geral são áreas com centralidade baixa em saúde e situação frágil quanto aos leitos por habitantes. Em sua maioria consistem em regiões imediatas e centros em menor número, ocupando grandes áreas, e também em regiões com os polos classificados nos níveis mais baixos de centralidade em saúde. Roraima, com apenas uma região imediata de articulação urbano-regional, possui uma rede com 15 centros urbanos, sete deles sem centralidade e sete com centralidade de baixa complexidade, destinando a Boa Vista - com centralidade 4 ou a Manaus com centralidade 2 - o atendimento em procedimentos de média e alta complexidade. Outra unidade federada com as mesmas características é o Amapá. 
As regiões imediatas litorâneas e as que abrigam a maioria dos grandes centros urbanos continuarão a atrair população, reforçando a necessidade de aumento de serviços para o atendimento nessas redes de mais alta complexidade. As grandes metrópoles do país, assim como outros centros com centralidade alta em saúde, provavelmente se manterão como os principais polos para os serviços de saúde. Este padrão de atendimento demonstra ser extremamente seletivo e desigual, uma vez que nem todos podem realizar deslocamentos para tratamento, principalmente aqueles de longa distância.

Quanto às regiões imediatas que mostram tendência de perda populacional, pode-se adiantar que estão localizadas, em maior número, na região Sul, que tradicionalmente apresenta um quadro demográfico com taxas negativas de crescimento. Nessas áreas o envelhecimento populacional, combinado com a emigração de força de trabalho jovem e adulta, contribui para a redução do volume demográfico. As regiões classificadas nesses padrões demográficos possuem quase todos os centros com centralidade em saúde entre 5 e 6, com atendimento de baixa complexidade, exceto Ilhéus-Itabuna (BA), classificada em nível 4.

Para finalizar, cabe reforçar a principal característica da população brasileira, que é a de cada vez mais concentrar-se em centros urbanos. Mais de $84 \%$ da população vivem em situação urbana, e este é um dos processos mais importantes da contemporaneidade, pois reúne ao longo de décadas, em espaços relativamente restritos, população e atividades. Do ponto de vista territorial, produz arranjos populacionais cujas características impulsionam processos socioespaciais bastante diferenciados quanto à densidade, fragmentação, orientação e centralidade. No Brasil, crescimento econômico e desenvolvimento urbano, consequentemente com acesso a melhores serviços e qualidade de vida, nem sempre caminham lado a lado, o que implica a necessidade de o Estado intervir e atuar para proteger os menos favorecidos.

Os estudos mais recentes, como Regiões de Influência das Cidades - 2007 (IBGE, 2008), que consideram, em seu escopo teórico-metodológico, a capacidade de concentração econômica e a infraestrutura, mostram, conforme já se afirmou, uma forte polarização de poucos centros, principalmente nas regiões Sudeste e Sul, formando redes urbanas onde a localização revela-se mais importante que o tamanho ou a posição na rede urbana.

Em contrapartida, se o modelo de crescimento tem sido feito por meio da expansão do mercado interno e do reforço das desigualdades, as políticas socioeconômicas devem atuar a fim de diminuir as lacunas em setores fundamentais como a saúde e a educação. Os programas implementados têm alcançado a população mais pobre, de forma a diminuir as disparidades de acesso aos serviços básicos, mas a persistência de crises constantes nestes setores revela-se preocupante.

Para um cenário futuro, as políticas de saúde devem respeitar as relações complexas entre economia e território, pois configuram um desafio num contexto de disparidades e diversidade do espaço nacional. 
Figura 8 - Características de atendimento à saúde e hierarquia urbana - 2010-2033

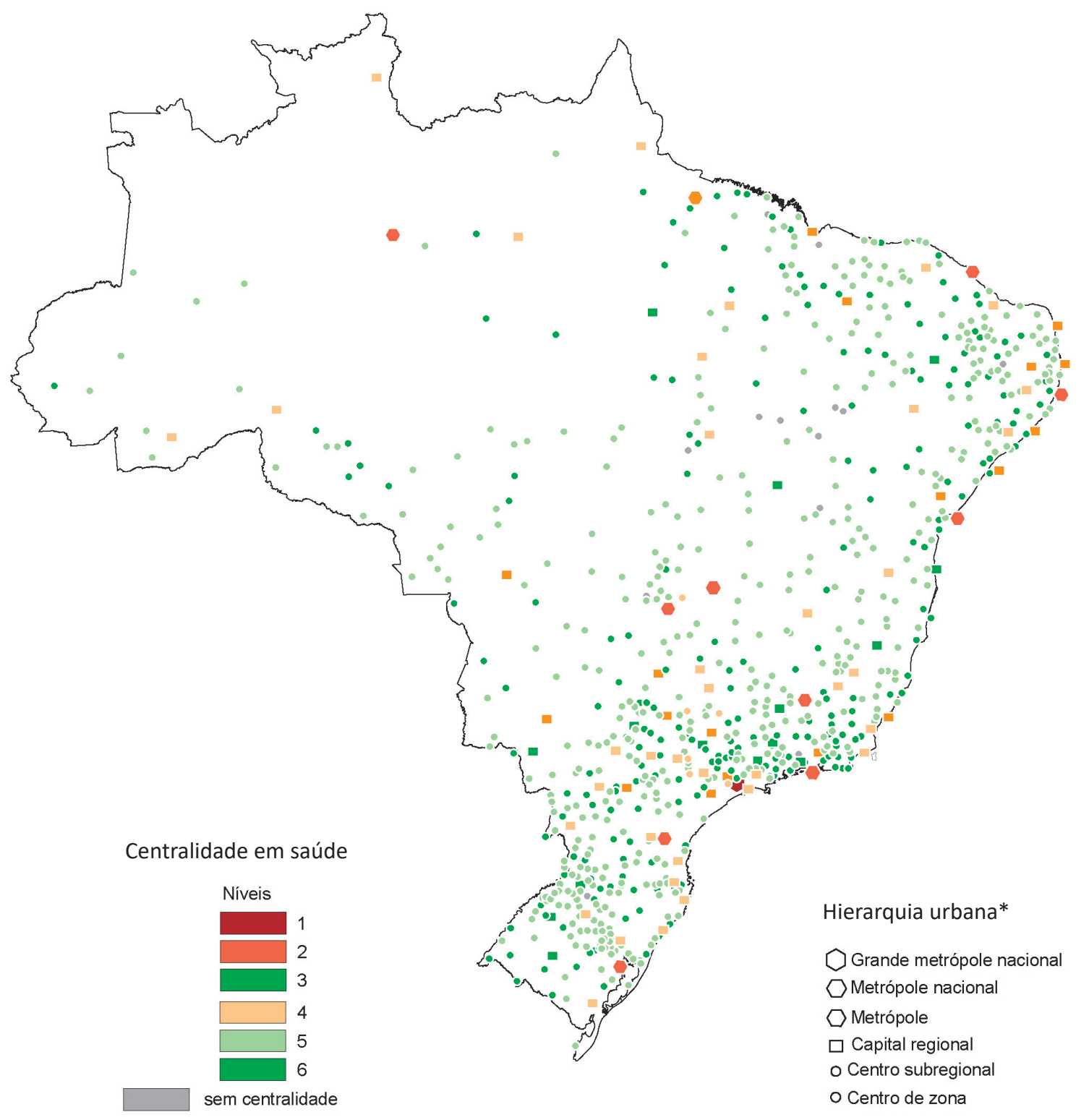

* Dados organizados por regiões imediatas de articulação urbana e centros urbanos até o nível de centros de zona. Fonte: elaboração dos autores com base em IBGE, 2008, 2010. 
Figura 9 - Tendências da dinâmica populacional - 2010-2033*

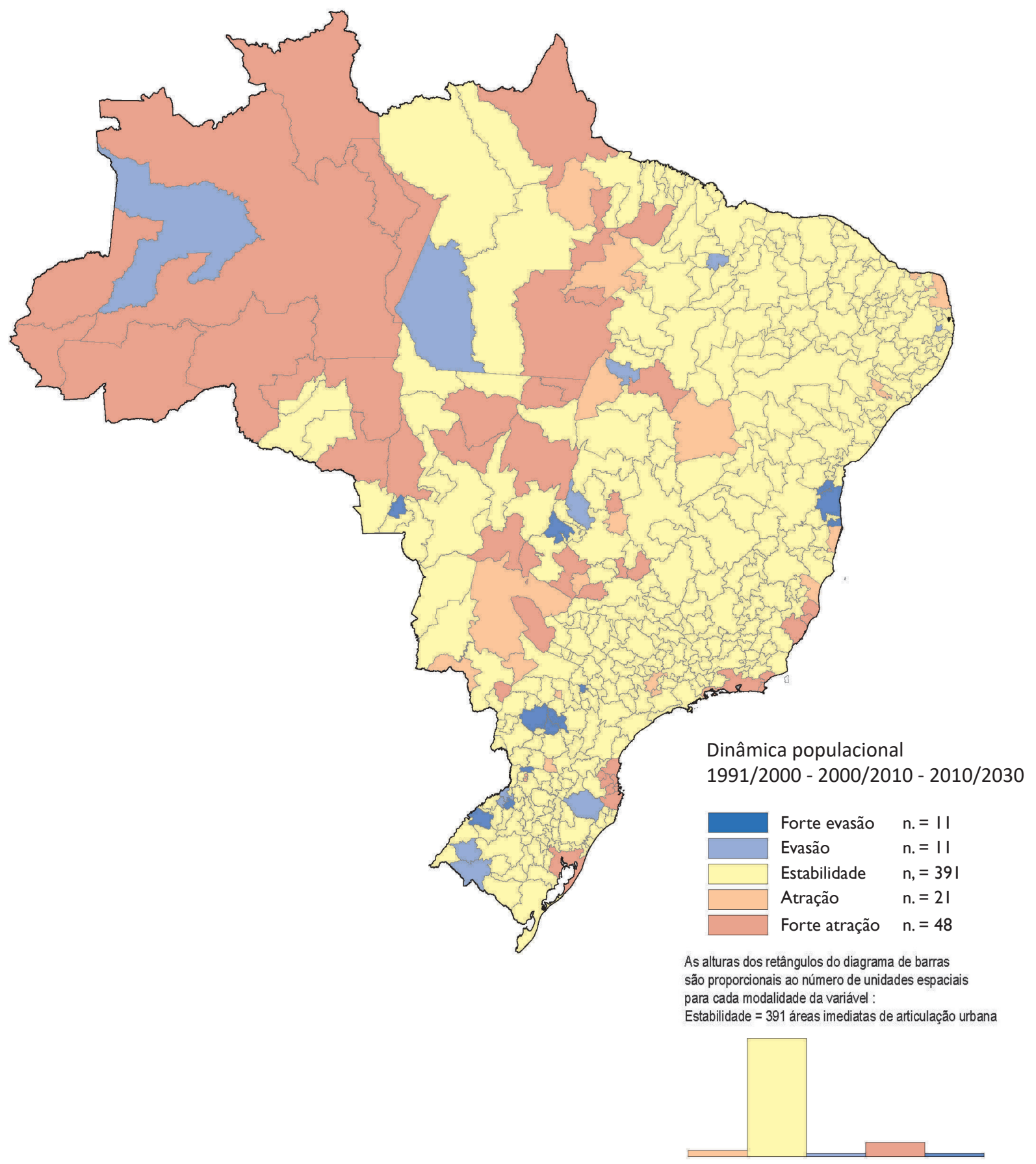

* Dados organizados por regiões imediatas de articulação urbana e centros urbanos até o nível de centros de zona. Os centros urbanos que formam ACPs, com exceção do núcleo, não foram mapeados.

Fonte: elaboração dos autores com base nos Censos Demográficos de 1991, 2000 e 2010 (IBGE, 2014a, 2014b, 2014c). 


\section{Considerações Finais}

Destacam-se, neste capítulo, as profundas assimetrias na dinâmica demográfica e na oferta dos serviços de saúde entre diversas regiões do país. Tais diferenças e desigualdades respondem aos distintos estágios de desenvolvimento econômico e social dessas áreas. Como visto, o ritmo de declínio das taxas de fecundidade total tende a pressionar este indicador que ficará em um nível abaixo da reposição em todo o território nacional; o processo de envelhecimento populacional segue tendência crescente e inexorável; e a chamada “janela demográfica”, que está se fechando no Sudeste e Sul, ainda permanecerá aberta por um período maior de tempo no Norte e Nordeste. A transição demográfica brasileira tem como caraterística marcante ao menos duas transições dentro dela, ao norte e ao sul do país. Esse cenário, que produzirá impactos importantes no mercado de trabalho, na produtividade da força de trabalho, no sistema de proteção e previdência social e na área da saúde, deve ser levado em consideração no momento de definição das políticas públicas.

Os desafios são enormes. O aproveitamento do que resta do bônus demográfico, o desejado salto tecnológico e o necessário aumento da produtividade, para fazer frente contra um quadro futuro de redução da população em idade de trabalhar, requerem investimento na melhoria da qualidade do ensino. Isto significa pensar educação e mercado de trabalho na perspectiva do envelhecimento da população.

Do ponto de vista da proteção social, embora os impactos do envelhecimento na previdência social sejam os mais propalados, gerando um certo catastrofismo por parte dos setores mais conservadores da sociedade, devem ser pensadas as questões que dizem respeito aos cuidados e atenção integral à população idosa, o que demandará infraestrutura de serviços que garantam vida ativa e integrada socialmente, sem perder de vista a necessidade da atenção às crianças e aos adolescentes.

Em relação à saúde, normalmente são feitas referências aos tipos de morbidades correlacionadas ao aumento da população em idades avançadas, que demandarão pesados investimentos. Contudo, pouco se fala do crescimento do segmento adulto jovem que aumentará o volume de pessoas expostas às morbidades e óbitos associados às causas externas. Esse aspecto da transição demográfica introduz uma questão até então não colocada na agenda da saúde.

Ressaltamos que não se pode desconsiderar as disparidades regionais na dinâmica demográfica e na oferta dos serviços de saúde. O cenário para os próximos vinte anos sinaliza estabilidade no crescimento populacional na maior parte das regiões imediatas de articulação. Poucas regiões continuarão a atrair população e algumas outras poucas seguirão como áreas de evasão populacional, o que poderá proporcionar maior segurança num planejamento que combine a tendência demográfica e os níveis de centralidade em saúde.

Enfim, todas essas políticas devem ser pensadas no âmbito de projeto de nação que vise a alcançar o desenvolvimento econômico e social a ser aproveitado por toda a sociedade. Isso implica eliminar ou reduzir drasticamente as desigualdades, pautar-se pela garantia dos direitos humanos e investir na prestação de serviços que sejam universais. 


\section{Referências}

CASTELO BRANCO, CASTELO BRANCO, M. L. G. Áreas de concentração de população. In: ENCONTRO NACIONAL DE PRODUTORES E USUÁRIOS DE INFORMAÇÕES SOCIAIS, ECONÔMICAS E TERRITORIAIS, 2, 2006, Rio de Janeiro. Anais.... Rio de Janeiro: IBGE, 2006.

BRASIL. Ministério do Trabalho e Previdência Social. Site. Disponível em: <http://portal.mte.gov.br/data/fi les/8A7C816A2E7311D1012ED8D282D817AF/1\%20-\%20Autoriza\%C3\%A7\%C3\%B5es\%20Concedidas\%20 a\%20Estrangeiros\%20por\%20Tipo\%20de\%20visto.pdf>. Acesso em: 6 jan. 2014.

CANALES, A. I. Discurso demográfico y posmodernidad: una revisión crítica del pensamiento malthusiano. Estudios Sociológicos, 19(2): 381-417, 2001.

CARVALHO, J. A. M. O saldo dos fluxos migratórios internacionais no Brasil na década de 80: uma tentativa de estimação. In: PATARRA, N. L. (Org.). Emigração e Imigração Internacionais no Brasil Contemporâneo. Campinas, São Paulo: Fnuap, Oficina Editorial, 1996.

INSTITUTO BRASILEIRO DE GEOGRAFIA E ESTATÍSTICA (IBGE). Regiões de Influência das Cidades 2007. Rio de Janeiro: IBGE, 2008.

INSTITUTO BRASILEIRO DE GEOGRAFIA E ESTATÍSTICA (IBGE). Pesquisa de Assistência Médico-Sanitária 2009. Rio de Janeiro: IBGE, 2010.

INSTITUTO BRASILEIRO DE GEOGRAFIA E ESTATÍSTICA (IBGE). Divisão Urbano-Regional do Brasil 2013. Rio de Janeiro: IBGE, 2013a.

INSTITUTO BRASILEIRO DE GEOGRAFIA E ESTATÍSTICA (IBGE). Projeção da população do Brasil por sexo e idade para o período 2000/2060. Projeção da população das Unidades da Federação por sexo e idade para o período 2000/2030. Rio de Janeiro: IBGE, 2013b. Disponível em: <ftp://ftp.ibge.gov.br/Projecao_da_Populacao/ Projecao_da_Populacao_2013/nota_metodologica_2013.pdf>. Acesso em: 5 jan. 2014.

INSTITUTO BRASILEIRO DE GEOGRAFIA E ESTATÍSTICA (IBGE). Censo Demográfico de 1991. Rio de Janeiro: IBGE. Disponível em: <www.ibge.gov.br/home/estatistica/populacao/censodem/default.shtm>. Acesso em: 5 jan. 2014a.

INSTITUTO BRASILEIRO DE GEOGRAFIA E ESTATÍSTICA (IBGE). Censo Demográfico de 2000. Rio de Janeiro: IBGE. Disponível em: <www.ibge.gov.br/home/estatistica/populacao/censo2000/default.shtm>. Acesso em: 5 jan. 2014b.

INSTITUTO BRASILEIRO DE GEOGRAFIA E ESTATÍSTICA (IBGE). Censo Demográfico de 2010. Rio de Janeiro: IBGE. Disponível em: <www.ibge.gov.br/home/estatistica/populacao/censo2010/caracteristicas_da_populacao/ default_caracteristicas_da_populacao.shtm >. Acesso em: 5 jan. 2014c.

OLIVEIRA, A. T. R. \& O’NEILL, M. M. V. C. Cenário sociodemográfico em 2022/2030 e distribuição territorial da população: uso e ocupação do solo. In: GADELHA, P.; CARVALHO, J. N. \& PEREIRA, T. R. (Orgs.). A Saúde do Brasil em 2030: diretrizes para a prospecção estratégica do sistema de saúde brasileiro. v. 1. Rio de Janeiro: Editora Fiocruz, Ipea, Ministério da Saúde, Secretaria de Assuntos Estratégicos da Presidência da República, 2013.

OLIVEIRA, A. T. R. et al. Notas sobre a migração internacional no Brasil na década de 80. In: PATARRA, N. L. (Coord.). Emigração e Imigração Internacionais no Brasil Contemporâneo. Campinas, São Paulo: Fnuap, Oficina Editorial, 1996.

OLIVEIRA, E. X. G.; CARVALHO, M. S. \& TRAVASSOS, C. Territórios do Sistema Único de Saúde: mapeamento das redes de atenção hospitalar. Cadernos de Saúde Pública, 20(2): 386-402, 2004.

PEREIMA, J. B. \& PORSSE, A. A transição demográfica, acumulação de capital e progresso tecnológico: desafios para o crescimento brasileiro. Revista Economia \& Tecnologia, 9(1): 49-60, 2013.

SIMÕES, C. C. S. A Transição da Fecundidade no Brasil: análise de seus determinantes e as novas questões demográficas. São Paulo: Arbeit Factor, 2006. 


\title{
GESTÃO PÚBLICA NO BRASIL DO SÉCULO XXI: TENDÊNCIAS REFORMISTAS E O DESAFIO DA PROFISSIONALIZAÇÃO
}

\author{
Ricardo Carneiro \\ Flávia de Paula Duque Brasil
}

Como prover bens e serviços de forma a satisfazer as necessidades básicas de consumo dos indivíduos, tendo em vista o incremento do bem-estar social? Tem-se aqui uma das questões mais centrais e, ao mesmo tempo, mais polêmicas da teoria e da prática política contemporâneas. Abordá-la requer considerações acerca das relações concretas que se estabelecem na sociedade quanto à apropriação e alocação dos recursos produtivos e à distribuição dos resultados alcançados, o que remete, por sua vez, às noções de Estado e mercado. Com lógicas de funcionamento distintas e portadores de resultados também distintos, a coexistência desses dois mecanismos alternativos de coordenação de interesses não escapa a uma permanente tensão, em que a competência de um frente ao outro é o que está em jogo.

Sem desconhecer os riscos de uma simplificação excessiva, é relativamente consensual que cabe ao poder público definir e legitimar objetivos e metas coletivas, o que envolve a padronização e distribuição de recursos, bem como o desenvolvimento e a manutenção de sistemas de controle burocrático, com implicações de natureza e intensidade variadas nas relações sociais e produtivas dos diversos campos de atividade. Fica claro, em tal proposição, o entrelaçamento da discussão do tema com "recomendações, valoração normativa e prescrições" (Vincent, 1987: 41), o que, evidentemente, limita qualquer pretensão de uma convergência interpretativa mais geral. A revivescência de um discurso aderente à lógica do mercado no contexto das últimas décadas do século $\mathrm{XX}$, em que o intervencionismo estatal nos campos econômico e social parecia constituir um fenômeno natural, e sua derrocada na transição para o século XXI reafirmam, na prática, que não há respostas definitivas para a questão.

Discussões consequentes relativas ao Estado, contudo, implicam considerações não apenas acerca das funções que desempenha, mas também da forma como se estrutura para fazer o que faz, ou o que se espera que faça. A esse respeito, cabe observar que o denominador comum dos movimentos de reforma do Estado é o desenho de arranjos organizacionais e mecanismos institucionais capazes de assegurar a melhoria de seu desempenho operacional e a efetividade na implementação das ações que compõem a agenda de governo. Aponta-se aqui na direção das reformas na gestão pública, que ganharam particular saliência, no plano internacional, com o reformismo gerencial identificado à New Public Management (NPM), cuja emergência pode ser associada à hegemonia conquistada pelo pensamento neoliberal no decorrer dos anos 1970. 
Balizado por essas considerações gerais, busca-se examinar as reformas na gestão pública do Brasil no período contemporâneo, com destaque para as principais tendências reformistas que se desenrolam no século XXI. Para tanto, faz-se, inicialmente, uma breve incursão na literatura sobre a natureza das reformas processadas na gestão pública no plano internacional, dirigindo-se a atenção, na sequência, para a abordagem da trajetória percorrida por tais reformas no plano nacional. O passo seguinte consiste na análise, um pouco mais detida, das reformas que ganham corpo no país desde os anos 1990, aglutinadas em torno de três eixos principais: a desconcentração administrativa e o hibridismo advindo dos novos arranjos organizacionais; a descentralização político-administrativa e a crescente saliência dos governos locais; e a governança democrática, colocando em relevo as instituições participativas. A parte final é dedicada à discussão do desafio, ainda em aberto, referente à profissionalização da administração pública brasileira, considerando, entre outras dinâmicas, os próprios processos de reforma do Estado, bem como a perspectiva do aprofundamento democrático.

\section{Sobre as Reformas na Gestão Pública}

Esta seção procura situar, analiticamente, as transformações processadas na gestão pública como uma dimensão do movimento mais amplo de reforma do Estado. Destaca-se, na primeira parte, a ocorrência de determinadas ondas reformistas da administração pública, tipificadas pela implantação das reformas que gravitam em torno do modelo burocrático weberiano e, mais recentemente, pelo reformismo da NPM. Na segunda parte, examina-se a inserção do país nessas ondas reformistas, enfatizando-se as convergências e divergências em face do que se passa no plano internacional.

\section{As principais ondas reformistas e as tendências contemporâneas}

Reformas na administração pública constituem um fenômeno intrínseco à própria natureza do Estado, cujas funções tendem a se alterar ao longo do tempo, com implicações conexas sobre sua estrutura organizacional e a forma como esta opera. No entanto, as iniciativas reformistas não se prendem estritamente a razões de adequação da capacidade operacional às cambiantes funções desempenhadas pelo poder estatal. Ao contrário, uma ideia força que impulsiona ou justifica o reformismo é a intenção declarada de aprimorar o funcionamento do setor público (Kettl, 2005). Os fins visados por tal aprimoramento são os mais variados, incluindo desde a redução do gasto público à melhoria na qualidade dos serviços públicos prestados à população, passando por argumentos relacionados ao incremento da eficiência e da efetividade da ação governamental.

De um modo geral, os esquemas de reforma não tendem a ser abrangentes, mesmo em suas intenções. Conforme Pollitt e Bouckaert (2004: 26), os reformistas buscam "aprimorar uma instituição ou um programa, ou, às vezes, um setor inteiro (saúde, educação), mas raramente remodelar o conjunto das instituições do setor público de uma vez". Algumas poucas reformas do setor público assumem uma configuração mais abrangente, em termos de escopo e de abrangência espacial. Isto permite falar, como o fazem Christensen e Laegreid (2012), da existência de ondas reformistas, traduzindo um conjunto de iniciativas de mudanças na estrutura, processos e práticas das organizações que compõem a administração pública, informadas por pressupostos similares e movidas por razões 
também similares, que se disseminam por um número expressivo de países, com destaque para aqueles de maior grau de desenvolvimento. No entanto, ainda que diferentes países se envolvam numa determinada onda reformista, a reforma da administração pública, como salienta Lynn Jr. (2007: 46), configura-se como uma "questão primariamente nacional", refletindo a influência de uma série de fatores, dentre os quais as características do sistema político, com suas configurações próprias e "padrões regulares de ação e decisão" (Lima Jr., 1998: 21), que podem facilitar ou restringir sua implementação (Pollitt \& Bouckaert, 2004).

As ondas reformistas a que se referem Christensen e Laegreid (2012) não implicam transformações abruptas na organização do setor público e em seu modus operandi. Ao contrário, o que se tem é um processo gradual de mudanças, tornando até mesmo difícil "identificar o fim de uma onda reformista e o começo de outra" (Christensen \& Laegreid, 2012: 262). Como mostra o caso americano, examinado por March e Olsen (1989), as mudanças mais efetivas e duradoras na administração pública do país ocorreram de forma gradativa, numa dinâmica em que os intentos reformistas frequentemente não se materializam ou apresentam resultados muito aquém do pretendido.

O que motiva ou desencadeia uma onda reformista é a percepção de problemas no funcionamento do setor público, sejam eles relacionados a questões de coordenação e controle das organizações que o compõem ou a deficiências em capacidade operacional de prover bens e serviços à população. Essa percepção pode ser influenciada, e na prática o é, por ideias e pressões de origem variada, além de mostrar-se suscetível a revisões ao longo da implementação das iniciativas reformistas que, como visto, caracterizam-se pelo gradualismo, abrindo espaço para frequentes correções de rumo ou mesmo a retroação. Dessa dinâmica reformista não resulta, como argumentam Christensen e Laegreid (2012), uma ruptura com o sistema político-administrativo existente, mas sua remodelação. Há, na interpretação dos autores, uma articulação entre o novo modelo proposto e aquele existente, produzindo um sistema administrativo híbrido, em que se combinam elementos trazidos pelas reformas com elementos tradicionais da arquitetura do sistema anterior. Tal articulação pode ser vista como um processo de sedimentação, no sentido de que novas reformas vão se adicionando a reformas pretéritas, com a coexistência de elementos originários de distintas eras ou ondas reformistas.

Uma das ondas reformistas mais marcantes da sociedade moderna é aquela que resultou na denominada "administração pública progressiva", cuja emergência remete às décadas finais do século XIX (Hood, 1995). Como mostra ampla literatura, ${ }^{1}$ esse movimento reformista, que converge para a adoção do modelo burocrático weberiano, busca lidar com problemas relacionados à corrupção e ao uso abusivo do poder político, de um lado, e à incompetência operacional e ao desperdício de recursos públicos que a acompanha, de outro.

Outra importante onda reformista começa a tomar forma no último quartel do século passado. Trata-se das iniciativas congregadas sob o rótulo da NPM. Tal movimento faz contraponto à administração burocrática weberiana, traduzindo formalmente a preocupação com a melhoria no desempenho do setor público, notadamente no que se refere à prestação de serviços públicos à sociedade. Para

\footnotetext{
${ }^{1}$ Ver, a esse respeito, Carneiro e Menicucci (2011).
} 
lidar com os problemas atribuídos à burocracia, a NPM propõe uma série de iniciativas reformistas, de natureza variada, que procura imprimir maior agilidade, responsividade e eficiência à administração pública (Hood, 1991, 1995; Manning et al., 2009; Carneiro \& Menicucci, 2011).

Tais iniciativas são agrupadas por Dunleavy e colaboradores (2005) em torno de três eixos principais, descritos pelos autores como desagregação, competição e sistemas de incentivos econômicos inspirados na dinâmica de mercado. Dentre os componentes mais usuais ou recorrentes dos mencionados eixos, incluem-se elementos como: agencificação, descentralização inter e intragovernamental, terceirização e parcerias com empresas e organizações não governamentais. Gestados e postos em prática nos países anglo-saxões, os experimentos reformistas afinados com a NPM difundem-se pelos diversos países desenvolvidos a partir dos anos 1980, alcançando, na sequência, países em desenvolvimento, notadamente da América Latina.

Desde os anos finais do século passado, contudo, começam a se evidenciar os sinais de esgotamento do reformismo da NPM (Carneiro \& Menicucci, 2011), que se tornam mais nítidos a partir da transição para o século XXI. Tal esgotamento aparece associado não só ao fato de as reformas empreendidas apresentarem resultados aquém do prometido, em termos da melhoria do desempenho da administração pública, mas também à percepção do fato de elas serem portadoras de consequências não pretendidas, com destaque para a fragmentação ou desintegração sistêmica, suscitando crescentes problemas de coordenação e controle na implementação das políticas públicas (Pollitt \& Bouckaert, 2004; Hood \& Peters, 2004, Dunleavy et al., 2005; Christensen \& Laegreid, 2012). No rastro desse processo, a NPM começa a ser suplementada por outras iniciativas mudancistas, originando uma nova onda de reformas, designada por Christensen e Laegreid (2012) como pós NPM. São ações endereçadas a lidar com os problemas derivados da adoção das recomendações e práticas da NPM, o que significa esforços com vistas a restabelecer uma situação de maior "integração, coordenação e capacidade" (Christensen \& Laegreid, 2007: 1.060) de atuação no setor público.

Esse quadro coloca em relevo conceitos como governança e accountability, ao lado do papel do governo central (Carneiro \& Menicucci, 2011). Trata-se do reconhecimento da necessidade de introduzir mudanças na forma como o governo atua, tendo em vista a crescente complexidade das ações de coordenação e controle advindas tanto da multiplicação das parcerias com atores da sociedade civil e do mercado, quanto da intensificação da heterogeneidade interna ao aparato público, no que se refere às estruturas, funções e interesses das organizações que o compõem. Em complemento, há o reconhecimento, por parte de uma literatura mais crítica, de que reformas da administração pública não podem ser vistas apenas como uma questão de natureza técnica, mas fundamentalmente como uma questão política (Christensen \& Laegreid, 2007; Bourgon, 2010; Carneiro \& Menicucci, 2011). E como uma questão política ela implica o compromisso com o aprofundamento democrático, consoante as premissas de um governo aberto e inclusivo. Para tanto, é indispensável uma burocracia não apenas profissionalizada, mas de perfil distinto, que alie capacidade técnica a capacidade política, tendo em perspectiva uma interlocução mais estreita e profícua com a sociedade, de modo a favorecer ações que sejam mais coerentes e aderentes à ideia de uma cidadania ativa (Carneiro \& Menicucci, 2011). 
A maneira como os diferentes países se engajam nas ondas reformistas, bem como o conteúdo e o percurso das reformas neles ocorridas, apresentam conformação muito variada. Isto não surpreende na medida que as condições internas de cada país, no que diz respeito às variáveis que influenciam as escolhas relativas ao tipo de reforma a adotar e a viabilidade de sua implementação, em que se destacam as características de seus sistemas político-administrativos, são muito distintas. O que se tem é uma típica dependência de trajetória, com pontos de partida não apenas diferentes, mas que se alteram de forma também desigual ao longo do tempo. É o que ocorre, em particular, no Brasil, que sequer conseguiu implantar uma administração pública burocrática, profissionalizada e meritocrática, a despeito de tal propósito ser reiterado nos textos constitucionais promulgados ao longo do século XX. E que adere ao reformismo gerencial no âmbito de uma agenda política que preconiza o ajuste fiscal como suporte à estabilização monetária, ou seja, por razões macroeconômicas e não propriamente administrativas.

\section{A inserção brasileira nas reformas da gestão pública}

A adesão do Brasil aos movimentos reformistas internacionais é tardia, uma vez que o país não se colocou na vanguarda das reformas, incorporando-se às mesmas com relativa defasagem temporal. Isso se aplica tanto à construção da administração burocrática clássica quanto à adoção do reformismo associado à NPM. A exceção se manifesta nas tendências que se seguem às reformas da NPM, com destaque para a temática da governança democrática, cuja entrada na agenda pública brasileira é contemporânea ao que se passa no plano internacional.

Ao caráter tardio se soma uma relativa frouxidão na implementação das ações reformistas, que assumem caráter parcial ou inconcluso, na linha daquilo que Rezende (2002) designa como falha sequencial. Observam-se também enormes desigualdades federativas no encaminhamento das ações reformistas e em seus resultados, seja sob a ótica vertical - os diferentes níveis de governo - seja horizontal - os governos estaduais e os locais. Tal fato em nada surpreende, dada a heterogeneidade que marca a realidade brasileira em suas várias dimensões, especialmente na dimensão políticoadministrativa. Na perspectiva vertical, os avanços mais expressivos tendem a se dar no âmbito do governo federal; na perspectiva horizontal, os principais avanços indicam a direção dos governos estaduais e locais das regiões mais ricas ou desenvolvidas.

A primeira onda de reformas da administração pública, fundada na adoção das premissas do modelo burocrático weberiano, chega ao Brasil com relativo atraso, comparativamente aos países que compõem o núcleo central do capitalismo ocidental. Introduzida nas principais nações europeias ainda no século XIX e nos Estados Unidos no início do século XX (Bresser-Pereira, 1996), a concepção clássica de burocracia só começa a ganhar corpo na agenda pública brasileira no decorrer da década de 1930, com a ascensão de Getúlio Vargas ao poder. Tem-se então um processo de centralização política, racionalização e modernização administrativa, que se articula em torno do propósito de industrialização liderada pelo Estado. Tal propósito "depende, nitidamente, da criação de meios apropriados para financiar, subsidiar, controlar e supervisionar" as políticas públicas formuladas em prol da promoção do desenvolvimento econômico (Nunes, 1997: 56). Sua materialização envolve, de um lado, a implantação de estatutos normativos e órgãos normativos fiscalizadores e, de outro, a estruturação de um aparato administrativo profissionalizado e meritocrático. 
O esforço reformista empreendido no período fica emblematizado na criação, em 1938, do Departamento de Administração do Serviço Público (Dasp), ao qual cabia a responsabilidade de definir, racionalizar e controlar a carreira do funcionalismo público, bem como de organizar a estrutura administrativa do governo federal. Em cumprimento às suas atribuições, o órgão definiu normas e regras de admissão e recrutamento de pessoal para o serviço público, baseado no sistema de mérito e na realização de concursos públicos, competitivos e obrigatórios - princípios fundamentais de uma burocracia profissionalizada, de conformação weberiana. No entanto, sua ação não deixou de ser limitada, refletindo a necessidade do uso da máquina pública para fins de obtenção de apoio político.

Trata-se de uma espécie de vício de origem, que cerceia as possibilidades de se implantar no país um serviço público profissionalizado, de aplicação universal. De fato, desde a Constituição Federal de 1934, quando se introduziu o concurso público como regra geral para acesso aos cargos públicos, todos os textos constitucionais brasileiros, ao mesmo tempo que reafirmam o compromisso com a profissionalização, abrem brechas ${ }^{2}$ que se contrapõem "ao espírito da burocracia racional-legal" (Lima Jr., 1998: 28). Na práxis administrativa, a convivência de uma burocracia profissionalizada com práticas políticas arcaicas, no sentido de pré-burocráticas, se faz por meio da solução designada por Nunes (1997) como "insulamento burocrático".

O recurso à administração paralela é consagrado pelo decreto-lei n. 200, editado em 1967. Esse documento patrocinou o espraiamento da administração indireta pelas áreas que interessavam à agenda pública, notadamente aquelas mais diretamente vinculadas à promoção do desenvolvimento econômico. Ao lado disso, "as áreas que estavam fora do campo das prioridades ficavam na administração direta, que quase sempre funcionava com uma burocracia ineficiente, por conta de fatores como a patronagem, o cartorialismo e a falta de incentivos à profissionalização" (Abrucio, Pedroti \& Pó, 2010: 49-50).

A contratação de pessoal, nos termos da Consolidação das Leis do Trabalho (CLT), passa a ser utilizada para o preenchimento de cargos na administração direta, o que, na prática, significa a "dispensa do uso do concurso como mecanismo de entrada no serviço público" (Carvalho, 2011: 57). Dessa conduta resulta um aparato estatal composto por uma multiplicidade de "corpos administrativos, com formas de legitimidade e meritocracia diferentes e sem diálogo entre si, inviabilizando uma efetiva gestão de pessoal" (Abrucio, Pedroti \& Pó, 2010: 52).

Um novo ensaio de implantação de uma burocracia informada pelas premissas do modelo weberiano se dá com a promulgação da Constituição Federal (CF) de 1988 (Brasil, 2006), que dedica um capítulo específico ao tema da administração pública. Dentre as medidas introduzidas, incluem-se a adoção do princípio do concurso público, universalizado como forma de recrutamento de pessoal para o serviço público, e a previsão de planos de carreira, conjugando estabilidade e perspectiva

\footnotetext{
${ }^{2}$ Para fins de ilustração, a Constituição Federal de 1946 prescreve, no artigo 23 de suas disposições transitórias, que "os atuais funcionários interinos da União, dos Estados e Municípios, que contem com pelo menos cinco anos de exercício, serão automaticamente efetivados na data de promulgação deste Ato; e os atuais extranumerários, que exerçam função de caráter permanente há mais de cinco anos (...) serão equiparados aos funcionários para efeitos de estabilidade, aposentadoria, licença, disponibilidade e férias" (Brasil, 2014a). Algo similar se passa com os textos constitucionais posteriores, inclusive o de 1988.
} 
de progressão a longo prazo. Igualmente importante, estabelece-se o Regime Jurídico Único (RJU) nas administrações direta e indireta, rompendo com a diversidade de contratações no setor público vigente à época.

No entanto, como vários dispositivos constitucionais, a natureza do regime que passaria a vigorar não foi especificada no texto constitucional, sendo remetida para legislação posterior. Tal definição vai se dar por meio da lei n 8.112/1990, com a opção pelo regime de direito estatutário ou público. Essa normatização afeta particularmente as fundações e autarquias, que passam a se assemelhar à administração direta. E, a mesma lei, reproduzindo práticas presentes nas mudanças constitucionais anteriores, permite a transformação dos servidores civis em estatutários, fragilizando o propósito de restringir o recrutamento à realização de concurso. ${ }^{3}$

Decorrida uma década, o texto constitucional foi modificado por força da emenda constitucional n. 19/1998, cujo conteúdo reflete proposições feitas no Plano Diretor da Reforma do Aparelho do Estado (PDRAE), que, como se verá mais à frente, expressa a principal referência para a reforma de cunho gerencial idealizada pelo governo Fernando Henrique Cardoso. Das diversas alterações introduzidas pela emenda, uma das mais relevantes refere-se ao RJU, que passou a ficar restrito às denominadas funções exclusivas ou típicas do Estado. ${ }^{4} \mathrm{Em}$ conexão com essa mudança, houve a flexibilização da exigência de realização de concurso público para fins de recrutamento de pessoal, atrelando-a basicamente à investidura em cargo ou emprego público. Outra medida guarda relação com a estabilidade do servidor, também flexibilizada, "passando a ser justificada a demissão por insuficiência de desempenho" (Carvalho, 2011: 76). Por fim, foram introduzidos parâmetros de restrição orçamentária, que serão regulamentados pela lei complementar n. 101/2000 - conhecida como Lei de Responsabilidade Fiscal (LRF) -, que vincula os gastos com servidores ativos e inativos do setor público à gestão fiscal.

A administração pública brasileira adentra o século XXI sem alcançar a desejável e necessária profissionalização do servidor público, a despeito do fortalecimento e expansão, nos anos mais recentes, do sistema de mérito. Vale dizer, não se institucionalizou, no país, a organização do tipo weberiano, o que se evidencia, com maior nitidez, nos níveis subnacionais de governo.

Como as reformas burocráticas, a onda reformista da NPM também alcança o país com relativo atraso, em comparação com a sua emergência e disseminação no plano internacional. O marco do processo remete à criação, no início do primeiro mandato do governo Fernando Henrique Cardoso, do Ministério da Administração e Reforma do Estado (Mare), cuja proposta reformista ganha contornos formais com a edição, em 1995, do já mencionado PDRAE. Reproduzindo o diagnóstico que embasa o reformismo da NPM, o PDRAE parte de uma crítica à burocracia e, por extensão, à CF 1988, que teria, nos termos do documento, levado a "um retrocesso burocrático sem precedentes" (Brasil, 1995: 20). O alvo principal da crítica consiste no fato de a CF 1988 retirar, da administra-

\footnotetext{
${ }^{3}$ Para fins de ilustração, no âmbito do governo federal, de acordo com Marconi (2010), todos os servidores celetistas, com exceção daqueles vinculados às estatais, tornaram-se estatutários, o que envolveu cerca de 400 mil pessoas.

${ }^{4}$ Enquadram-se nessa categoria as carreiras relacionadas às atividades de defesa nacional, arrecadação tributária, "fiscalização, diplomacia, formulação de políticas públicas, elaboração e execução orçamentária e regulação" (Marconi, 2010: 231), além de segurança pública, nos níveis federal e estadual.
} 
ção indireta, a flexibilidade operacional de que esta dispunha desde a edição do decreto-lei n. 200, "ao atribuir às fundações e autarquias públicas normas de funcionamento idênticas às que regem a administração direta" (Brasil, 1995: 20).

A concepção mais geral da proposta reformista do Mare é informada pelas reformas econômicas de cunho neoliberal em curso no período. ${ }^{5}$ Refletindo essa sintonia, o PDRAE parte de uma demarcação das relações entre Estado e mercado, utilizando-a para especificar as áreas que seriam próprias do Estado ou nas quais sua atuação se justificaria, ${ }^{6}$ bem como as respectivas formas de propriedade e de gestão (Bresser-Pereira, 1996; Lima Jr., 1998). Dessa demarcação resulta a proposição de quatro setores para a atuação estatal, designadas como núcleo estratégico, atividades exclusivas, atividades ou serviços não exclusivos e área de produção de bens e serviços para o mercado (Bresser-Pereira, 1996). Com base em tal distinção, o PDRAE propõe um redesenho organizacional do aparato estatal, considerando formas de propriedade e de gestão, que se orienta na direção da desconcentração administrativa, inspirada no reformismo gerencial da Inglaterra.

Para as atividades estratégicas, o PDRAE reafirma o modelo burocrático weberiano, que ficaria estruturado, assim, em torno das carreiras típicas de Estado. Para as atividades referentes à produção de bens e serviços para o mercado, aponta-se para a privatização, consoante a lógica neoliberal, de precedência do mercado em relação ao Estado no tocante a alocações de recursos na economia, ficando a cargo de empresas estatais, a rigor, aquelas que não pudessem ser administradas privadamente (Bresser-Pereira, 1996). As principais inovações dizem respeito às atividades exclusivas e aos serviços não exclusivos. Para elas, o desejável, do ponto de vista do PDRAE, seria a flexibilidade operacional que a administração indireta dispunha anteriormente à promulgação da CF 1988, consoante o espírito do decreto-lei n. 200/1967.

A solução proposta consistiu na criação de duas novas formas organizacionais: a agência autônoma e a organização social (OS). Ambas seriam revestidas de maior autonomia administrativa e financeira, em face das normas de funcionamento impostas pela CF 1988 às administrações direta e indireta. A agência autônoma corresponde ao modelo organizacional delineado para os órgãos e entidades vinculadas às atividades exclusivas, enquanto a OS corresponde ao modelo aplicável às atividades ou serviços não exclusivos do Estado. Embora não mencionado no PDRAE, o governo federal introduziu, quase à mesma época da regulamentação das OSs, um novo arranjo capaz de assumir funções relacionadas aos serviços não exclusivos, designado como Organização da Sociedade Civil de Interesse Público (Oscip). Tal formato conflui formalmente para o propósito de ampliar o compartilhamento da prestação de serviços públicos com organizações não governamentais.

O reformismo gerencial preconizado pelo PDRAE teve fôlego curto, o que se evidencia na extinção do Mare no segundo mandato de Fernando Henrique Cardoso. Dos novos arranjos organizacionais propostos, pouca coisa saiu do plano das intenções, o que se aplica tanto às agências executivas quanto às OSs. Os avanços mais expressivos ocorreram na área da produção de bens e serviços para

\footnotetext{
${ }^{5}$ Iniciada no governo Collor, a agenda de reformas neoliberais se aprofunda no governo Fernando Henrique Cardoso.

${ }^{6}$ A referência mais geral para tal demarcação remete às denominadas falhas de mercado, consoante as premissas analíticas da economia neoclássica.
} 
o mercado, com a privatização de diversas empresas estatais. Essa mesma ênfase na privatização impulsionou a criação de agências reguladoras, que expressam, ao lado das agências executivas, um dos formatos institucionais das agências autônomas, ainda que apenas brevemente mencionado no texto do Plano Diretor (Torres, 2007).

À paralisia das reformas gerenciais na esfera do governo federal, associam-se avanços no âmbito dos governos subnacionais, em especial dos estados. É o que se observa no tocante às proposições referentes aos novos formatos organizacionais aplicáveis às atividades não exclusivas do Estado, representados pelas OSs e Oscips. Como argumentam Abrucio, Pedroti e Pó (2010: 61), "tais formas deram mais certo nos estados que na União".

Mais recentemente, o país adere ao mecanismo da parceria público-privada (PPP), que se difunde no plano internacional, desde a década de 1990, como um novo arranjo institucional aplicado à realização de investimentos em infraestrutura ou à provisão de um serviço público. Embora não prevista na arquitetura do PDRAE, a PPP se coaduna com sua concepção mais geral, alargando o espaço de atuação da iniciativa privada tanto na área de serviços não exclusivos quanto na de serviços para o mercado.

Ao lado dos ensaios feitos a fim de adotar arranjos organizacionais e instrumentos que confluem para as proposições reformistas da NPM, há, desde meados dos anos 1990, um notável avanço na direção da descentralização, notadamente no campo das políticas sociais, que não pode ser visto ou interpretado como decorrência de uma adesão ao paradigma gerencialista. O que se tem é um movimento conectado a um viés mais político, remetendo aos potenciais democratizantes e de aprofundamento democrático da gestão pública, em sintonia com os princípios orientadores e as diretrizes da CF 1988, que consagra o município como ente federado.

No caso dos países desenvolvidos, o impulso decisivo à descentralização é dado pela busca da melhoria de desempenho na provisão de serviços públicos à população, o que envolve processos mais próximos da noção de desconcentração, como a terceirização, a agencificação e as parcerias com o mercado e entidades da sociedade civil, dentre outros. No caso brasileiro, seguindo a trilha do que se observa na América Latina, a descentralização se faz no âmbito do movimento de redemocratização da vida política, o que lhe confere uma conotação distinta, de transferência de poder do nível central para os níveis subnacionais de governo. Trata-se, portanto, de um processo de descentralização política e administrativa, cujo foco é a prestação de serviços no campo social, definida como de competência comum ou partilhada no texto constitucional.

Outro movimento reformista de relevo no país guarda relação com a noção de governança, que começa a ser crescentemente empregada e difundida, desde os anos 1990, em temáticas relativas à gestão pública no plano internacional. Como observam diversos autores (Carneiro \& Menicucci, 2011; Christensen \& Laegreid, 2012; Klinj, 2012), a governança comparece às discussões críticas com o foco na NPM como um contraponto ou, distintamente, como um complemento às reformas administrativas - nesse caso, como uma forma de lidar com as consequências não pretendidas das reformas e como resposta às suas deficiências, com destaque para os déficits de inclusividade democrática. Assim, na literatura dos países centrais, a perspectiva de governança entremeia-se nos 
debates em torno das reformas da administração pública, na linha da NPM, sobretudo em virtude de seus desacertos e deficiências, e crescentemente abarca as possibilidades de participação democrática ou o viés participativo.

No caso brasileiro, e também no cenário de outros países latino-americanos, pode ser indicado um percurso distinto nas abordagens e práticas. No bojo da terceira onda de democratização, ocorrem expressivos processos de mobilização da sociedade civil, que se organiza de diversas formas, com plataformas de cunho democratizante e includente, voltadas para a descentralização, a ampliação de direitos sociais e a democratização das relações do Estado com a sociedade, por meio de mecanismos e de instâncias institucionais de participação. Tais agendas e propostas de reforma, seja no âmbito mais geral ou nos campos setoriais de políticas públicas, cunharam avanços no texto da CF 1988 e, nas décadas que se seguiram, modelaram inovações institucionais. No âmbito legal, a legislação das políticas sociais nos anos 1990 encampou a participação via conselhos como requisito obrigatório para repasse de recursos por meio de fundos, e na década seguinte, a legislação referente às políticas urbanas introduziu, de formas distintas, dispositivos relativos à participação.

A partir do final da década de 1980, os governos locais, de início aqueles de orientação política progressista ou democrático-populares, avançaram na criação de instituições participativas, como conselhos, orçamentos participativos, conferências municipais, arranjos participativos, na elaboração de planos diretores e correlatos, dentre outros desenhos mais específicos. No decurso das décadas seguintes, tais práticas afirmaram-se como tendência consolidada, observando-se a pluralidade e a multiplicação dessas instituições no âmbito local (Brasil \& Carneiro, 2010).

\section{Tendências Reformistas na Gestão Pública Brasileira do Século XXI}

Discutem-se a seguir as principais transformações em curso na administração pública brasileira, que, como visto na seção anterior, se articulam em torno de três eixos principais: a desconcentração intra e extragovernamental, a descentralização político-administrativa e a governança democrática. A abordagem relativa a cada eixo parte de uma rápida revisão teórica que informa a análise propriamente dita da temática em questão, na qual são feitas considerações acerca da trajetória percorrida e suas perspectivas de evolução num horizonte temporal de médio a longo prazo.

\section{Desconcentração extra e intragovernamental: novos arranjos organizacionais e hibridismo}

O movimento de reforma do Estado desencadeado nos anos 1970, com a ascensão do pensamento neoliberal, abriu espaço para uma maior penetração de agentes privados e de organizações não governamentais em áreas de atuação anteriormente de responsabilidade do setor público. Essa dinâmica é amplificada pelo reformismo da NPM, que se mobiliza, formalmente, em torno da melhoria da eficiência gerencial na provisão de bens e serviços à população (Dunleavy \& Hood, 1994; Manning et al., 2009; Pierre, 2009). Sob a influência da NPM, "os governos veem-se pressionados a cortar custos e ser mais responsivos e flexíveis na provisão de serviços" (Smith, 2007:591). Do processo 
resulta a proliferação de diferentes arranjos do setor público com organizações não governamentais e entes privados, implicando crescente hibridismo organizacional (Carneiro \& Menicucci, 2011).

Os novos arranjos postos em cena pela NPM vêm no rastro da intensificação da delegação da gestão de atividades de interesse público ou de competência da administração pública, mediante contratação, a um agente não estatal - empresa privada ou organização não governamental. Agrupadas sob o rótulo genérico de parceria, vão ser encontradas diversas formas de relação entre o setor público e entidades não estatais (Skelcher, 2007), que confluem para as noções de contracting out, out sourcing e joint venture, embora não se reduzam a elas.

Tais noções, convencionalmente associadas à terceirização, envolvem a "separação entre o comprador de um serviço e seu fornecedor" (Skelcher, 2007: 371). Nessa relação, a administração pública, na condição de comprador, fica com a responsabilidade pela especificação das características e condições de fruição do serviço, mas não por sua produção propriamente dita, cujo fornecimento é contratado a uma empresa privada ou organização não governamental. A natureza do serviço passível de ser adquirido é vasta, num arco que vai de atividades de provisão continuada pela administração pública, como coleta e disposição final de lixo, a atividades que se inscrevem no âmbito de uma dada política pública, como atendimento especializado a grupos mais vulneráveis da população (Skelcher, 2007).

As motivações para a realização desse tipo de parceria são variadas, dependendo não apenas da natureza do serviço contratado como do contexto político e cultural em que ocorre (Pollitt \& Bouckaert, 2002; Skelcher, 2007). A motivação mais recorrente listada na literatura é a busca pela redução de custos e ganhos de eficiência e qualidade na prestação do serviço público (Skelcher, 2007; Smith, 2007). Isto se fundamenta na presumida expertise do agente privado, o que também se aplica às organizações não governamentais, proporcionando ganhos de eficiência e inovação associados à especialização e ao melhor aproveitamento de ganhos de escopo e de escala. Além desse aspecto, interfere também no processo a maior autonomia decisória dos entes não estatais vis-à-vis a administração pública, no tocante às imposições de cunho institucional, que favorece a adoção de soluções, procedimentos e condutas mais ágeis e de menor custo. Menos frequentes, outras motivações guardam relação com os propósitos de contenção do tamanho da força de trabalho do setor público e de redução de suas responsabilidades diretas no gerenciamento da prestação do serviço.

Os limites ou potenciais problemas associados à terceirização remetem, de certa forma, a um exame mais criterioso das presumidas vantagens que revestem este tipo de parceria. A contratação pode, de fato, levar a operações mais eficientes, em termos técnicos e econômicos, mas, cabe observar, eficiência econômica não significa, necessariamente, que as operações sejam as mais adequadas às necessidades e opções do público interessado no serviço ou da sociedade como um todo. A chave para o sucesso da contratação consiste na definição criteriosa dos padrões de qualidade do serviço a ser prestado, o que nada tem de trivial, e na efetiva monitoria de sua prestação por parte da administração pública. Outro aspecto a ser observado diz respeito à existência de empresas ou organizações não governamentais com comprovada experiência e capacidade de atuação nos serviços que o governo deseja contratar, o que não necessariamente ocorre. No caso 
das organizações não governamentais, estas revelam-se "tipicamente subcapitalizadas", apresentando problemas com fluxo de caixa e capacidade de investir adequadamente em infraestrutura e força de trabalho profissionalizada (Smith, 2007: 596).

A noção de joint venture, por sua vez, remete a formas de cooperação entre o setor público e empresas privadas, tendo em vista o financiamento, a construção, a gestão ou manutenção de uma dada infraestrutura ou a prestação de um serviço (Comissão das Comunidades Europeias, 2004). São relações que se distinguem e se somam a instrumentos tradicionais de delegação da execução de funções ou atividades de interesse público a agentes do mercado, como a concessão e outras formas de descentralização extragovernamental. A lógica do processo requer a promoção de um projeto conjunto, em que as partes envolvidas mantêm sua coordenação como atores independentes, com escopo e repartição de responsabilidades bem definidos.

O gerenciamento desse tipo de relação contratual pode ser feito por meio de um acordo de parceria ou pela constituição de uma sociedade de fins específicos (Skelcher, 2007). As joint ventures são referidas como parcerias público-privadas (PPPs) no contexto europeu, onde emergem a partir da iniciativa pioneira do Reino Unido, com base na denominada Private Finance Iniciative, direcionada a viabilizar projetos de investimento público e a provisão de serviços a eles associados - iniciativa posteriormente relançada e renomeada como Public Private Partnership (PPP) (Brito \& Silveira, 2005). Sob esse rótulo genérico, as PPPs se difundem por vários países, com concepções distintas, informadas pelos respectivos marcos regulatórios. No Brasil, o modelo adotado emprega a terminologia PPP para expressar uma "forma de provisão de infraestruturas e serviços públicos em que o parceiro privado é responsável pela elaboração do projeto, financiamento, construção e operação de ativos, que são posteriormente transferidos ao Estado" (Brito \& Silveira, 2005: 8).

As motivações para a celebração de PPPs envolvem, como no caso da terceirização, a expectativa de que os serviços prestados pelo ente privado, empresa ou consórcio, possam ser desempenhados com maior eficiência econômica e qualidade (Comissão das Comunidades Europeias, 2004; Skelcher, 2007). Um dos principais argumentos embasando tal expectativa se ancora na possibilidade de integrar a elaboração do projeto executivo, sua construção e operação em um mesmo agente, gerando incentivos "não apenas à otimização dos custos com base no ciclo de vida do projeto" (Brito \& Silveira, 2005: 10), mas também a melhorias na qualidade do serviço prestado.

A agilização da implantação do investimento, potencializada pela definição de mecanismos de pagamento ao ente privado atrelados à disponibilidade do serviço, capazes de estimular o interesse por reduções no cronograma da obra, constitui outro benefício da PPP. Para além dos argumentos que focam ganhos de eficiência e qualidade, o debate referente às PPPs é perpassado pela questão do financiamento (Comissão das Comunidades Europeias, 2004). O argumento aqui remete à obtenção de espaço orçamentário para a realização de investimentos pelo setor público, o que ganha particular relevância em um quadro de restrições fiscais impondo limites ao endividamento. A parceria abre a possibilidade de diluir no tempo o aporte de recursos do setor público no projeto (Brito \& Silveira, 2005), com a transformação de um fluxo antecipado de investimento em fluxos correntes de pagamento por serviços prestados (Comissão das Comunidades Europeias, 2004). 
Como no caso da terceirização, a literatura também assinala problemas e limites no uso das PPPs, a começar pelos presumidos ganhos de eficiência que elas aportam. Ainda que vários estudos aplicados a países que adotaram o instrumento indiquem reduções de custos na prestação de serviços, comparativamente à provisão direta pelo setor público, ${ }^{7}$ há que se considerar o tipo de enfoque utilizado em tais análises. Em se tratando de prestação de serviço público, não se podem negligenciar, na avaliação do resultado, aspectos atinentes às externalidades positivas, cuja incorporação transcende abordagens informadas por critérios mais estritos de eficiência produtiva, típicos da lógica empresarial. Ao lado disso, existem expressivos custos de transação incorridos pelo setor público no processo, referentes à estruturação, contratação e monitoramento da parceria - atividades exigentes em termos de habilidades e conhecimentos especializados -, que devem ser levados em conta, embora não necessariamente o sejam. A questão dos ganhos de inovação revela-se mais controversa (Skelcher, 2007), sem evidências empíricas sólidas de sua ocorrência. No tocante à ampliação do espaço orçamentário, sua contraface é o comprometimento de receita futura, introduzindo um elemento de rigidez orçamentária, numa perspectiva de longo prazo, para o ente estatal responsável pelo financiamento ao esquema (Skelcher, 2007; Brito \& Silveira, 2005), limitando as escolhas de gastos abertas ao mesmo.

Junto com a intensificação da delegação da prestação de serviços públicos a entes não estatais, a agencificação emerge, no contexto do reformismo da NPM, como um instrumento de desconcentração intragovernamental em busca de níveis mais elevados de responsividade e desempenho de órgãos da administração pública. A agencificação expressa um processo de redesenho organizacional, focada na administração indireta, por meio da "individualização de entidades voltadas a propósitos específicos" (Pacheco, 2010: 196), designadas genericamente como agências. Reconfigurada como agência, a entidade governamental passa a dispor de mecanismos diferenciados de gestão, que lhe conferem maior autonomia decisória na alocação de recursos, comprometendo-se, em contrapartida, com a obtenção de determinados resultados, formalmente acordados por meio de contrato.

As principais críticas dirigidas à agencificação têm a ver com as consequências não pretendidas que acompanham sua implementação. Destaca-se, nesse contexto, a criação de um tecido organizacional mais fragmentado, com o aumento das unidades administrativas, criando inter-relações mais complexas e dinâmicas entre elas, o que traz não apenas maior dificuldade de coordenação na formulação e implementação de políticas públicas, como torna mais difícil, para o cidadão, entender os arranjos internos do Estado (Carneiro \& Menicucci, 2011). Outro aspecto refere-se ao efetivo controle da atuação das agências, tendo em vista as autonomias decisórias que lhes são concedidas. Não podem ser esquecidos, ademais, riscos de erosão da legitimidade e confiança, cujo fundamento primário são as regras da burocracia, flexibilizadas no processo de constituição de agências.

$\mathrm{Na}$ análise que faz da experiência internacional, focada em países da Organização para a Cooperação e Desenvolvimento Econômico (OCDE), Blöndal (2005) nota que a terceirização pode ser, e o é, aplicada de forma ampla. Por meio do instrumento, buscam-se ganhos de responsividade e

\footnotetext{
${ }^{7}$ Alguns desses estudos são mencionados por Skelcher (2007).
} 
eficiência na prestação de serviços, consoante as premissas da NPM. Manning e colaboradores (2009) observam, contudo, que, na América Latina, o que move a prestação alternativa de serviços tem a ver, em larga medida, com a disfuncionalidade de suas estruturas administrativas, em termos de capacidade técnica e operacional. O Brasil aproxima-se mais da realidade latino-americana que da OCDE, notadamente no que se refere aos níveis subnacionais de governo.

A terceirização não constitui fenômeno recente no país, como mostra sua previsão no âmbito do decreto-lei n. 200/1967. ${ }^{8}$ Na década de 1990, a lei n. 8.666/1993, que institui normas para licitações e contratos da administração pública, tratou também da matéria, permitindo que "as obras ou serviços sejam prestados por execução direta ou indireta" (Di Pietro, 1997: 118). De acordo com a regulamentação então instituída, a terceirização pode ser adotada em atividades instrumentais ao funcionamento da administração pública, sendo necessariamente precedida por licitação. Não se aplica, contudo, às atividades de cunho finalístico, à exceção dos serviços públicos que venham a ser objeto de concessão. À mesma época, a edição da lei n. 8.745 regulamentou a utilização do contrato temporário de pessoal, sem requisito de concurso público, para atender situações temporárias e de excepcional interesse público nelas descritas. A edição do decreto n. 2.271/1997 reafirmou, no âmbito do governo federal, o direcionamento da terceirização para as atividades acessórias, instrumentais ou complementares aos assuntos de natureza finalística, formalmente de competência dos órgãos e entidades da administração direta e indireta.

Mais recentemente, a LRF procurou restringir o uso indiscriminado da terceirização, estabelecendo que, nos contratos envolvendo trabalhadores terceirizados em substituição a servidores e empregados públicos, os valores envolvidos serão contabilizados como "outras despesas de pessoal". São restrições que não bloqueiam sua utilização na gestão de atividades exclusivas do Estado, como a administração de presídios (Tourinho, 2008), ou de atividades não exclusivas, como a saúde (Pereira, 2004; Pires, 2008) e a assistência social (Raichelis, 2010), envolvendo tanto empresas privadas de serviços e assessoria quanto cooperativas de trabalhadores. Embora não bloqueiem a terceirização, as dificuldades institucionais interpostas à sua utilização vêm estimulando a estruturação de novos arranjos organizacionais na gestão de atividades não exclusivas do Estado, sob a forma de OS e Oscip.

Nos termos do PDRAE, as OSs se configuram como "entidades de direito privado que, por iniciativa do Poder Executivo, obtêm autorização legislativa para celebrar contrato de gestão com esse poder, e assim ter direito a dotação orçamentária" (Brasil, 1995: 74). O modelo foi regulamentado por meio da lei n. 9.637/1998, que prevê a concessão de autonomias gerenciais às entidades assim qualificadas, atrelando-a à celebração de contratos de gestão. As flexibilidades administrativas previstas são relativamente amplas, cabendo destacar a possibilidade de contratar e demitir funcionários pelas regras da CLT e de adquirir bens e serviços com base em regimento próprio, e não nos dispositivos da lei n. 8.666/1993. De acordo com a legislação, a qualificação abrange as áreas de ensino, pesquisa e desenvolvimento tecnológico, proteção e preservação do meio ambiente e saúde.

\footnotetext{
${ }^{8}$ Como observa Di Pietro (1997: 118), o mencionado decreto "já previa a possibilidade de a Administração desobrigar-se da execução de tarefas executivas mediante a execução indireta, mediante contrato".
} 
Embora tenha sido o responsável por sua introdução, o governo federal pouco vem se utilizando da parceria com OSs. Transcorrida uma década de promulgação da regulamentação do modelo, havia apenas seis entidades qualificadas e com contratos de gestão vigentes no âmbito da administração federal $^{9}$ (Brasil, 2010), quase todas na área de pesquisa e desenvolvimento tecnológico. Trata-se de resultado que reflete, em parte, a polêmica em torno do modelo, questionado em sua legalidade por Ação Direta de Inconstitucionalidade (ADI), ${ }^{10}$ o que trouxe "insegurança para os atores que estavam envolvidos no processo de criação dessas instituições" (Torres, 2007: 73). Mais recentemente, o governo federal propôs a instituição do modelo de fundação pública de direito privado, mais conhecido como fundação estatal. A iniciativa foi objeto do projeto de lei complementar n. 92/2007 que, até o final de 2013, ainda se encontrava em tramitação no Congresso Nacional. O modelo aplica-se a áreas que confluem, em larga medida, para aquelas previstas na regulamentação das OSs. Alguns estados, como Bahia e Rio de Janeiro, já aprovaram legislação própria sobre a matéria e vêm ensaiando a aplicação do modelo na área da saúde.

É na esfera subnacional de governo que a OS vem encontrando terreno mais fértil. De acordo com estudo da Secretaria de Gestão (Seges) do Ministério do Planejamento, Orçamento e Gestão (Brasil, 2010), nada menos que 15 estados e 42 municípios haviam criado regulamentação própria da matéria até o ano de 2008, em sua maior parte tomando como referência a legislação federal. Nota-se, em diversas legislações estaduais e, principalmente, em legislações municipais, uma maior amplitude de áreas para a atuação das OSs, sinalizando uma maior predisposição em aplicar o modelo. Pelo mesmo estudo, existiam, em 2008, 112 OSs qualificadas por governos estaduais e outras 52 por governos municipais, embora nem todas tivessem, à época, contratos de gestão celebrados com a administração pública.

A área da saúde é uma das que mais se destacam no tocante à parceirização com OS na esfera subnacional de governo. A adoção do modelo, contudo, tem se processado sem o adequado aparelhamento da administração pública, enquanto contratante, para zelar pela qualidade do serviço prestado pela contratada. É o que mostra auditoria realizada pelo TCU, em 2012, nos estados de São Paulo, Bahia, Paraíba, Paraná e Rio de Janeiro, referente à transferência do gerenciamento de serviços públicos de saúde a OSs. Tal auditoria encontrou problemas em todos os contratos de gestão examinados, envolvendo tanto a fase de contratação quanto a de acompanhamento da execução das atividades pelas OSs. ${ }^{11}$ Segundo a análise realizada, as falhas e irregularidades encontradas refletem, em larga medida, déficits de capacidade gerencial das administrações envolvidas, o que se expressa em equipes reduzidas e sem a necessária qualificação.

\footnotetext{
9 A Associação Brasileira para o Uso Sustentável da Biodiversidade da Amazônia - Biomazônia, que havia sido qualificada como OS em 1999, teve seu contrato de gestão rompido em 2005, junto com a desqualificação da organização.

${ }^{10}$ ADI 1923 foi ajuizada pelo Partido dos Trabalhadores e pelo Partido Democrático Trabalhista, em 1998, contra a natureza jurídica das OSs.

${ }^{11}$ Os principais problemas ou irregularidades constatadas envolvem: o processo decisório relativo à terceirização não demonstra que esta constitui a melhor opção para o setor público; a qualificação e a seleção são, em muitos casos, mera formalidade; a delegação inclui, em alguns casos, atividades exclusivas do poder público; contratação sem fundamentação legal; ausência de indicadores para uma adequada avaliação do desempenho da OS; e controle insuficiente para garantir a regularidade na gestão dos recursos (TCU, 2014b).
} 
No entanto, a despeito dos problemas explicitados pela auditoria do TCU, é de se esperar a adesão de novos governos subnacionais ao modelo. ${ }^{12}$ À medida que a parceria com OSs se difunde, e ela vem se difundindo, outros governos podem considerar a opção de adotá-la, por isomorfismo mimético, ${ }^{13}$ avaliando-a como uma alternativa à construção de capacidade para implementar diretamente atividades de sua competência, sem o respaldo de uma análise mais criteriosa da conveniência e dos riscos de tal decisão.

Ao lado das OSs, outra forma de transferência da gestão da prestação de serviços públicos à população consiste na parceria com as Oscips. Instituído na esfera do governo federal pela lei n. 9.790/1999 e regulamentado pelo decreto n. 3.10/1999, o modelo envolve a qualificação, pelo Ministério da Justiça (MJ), de associação ou fundação civil sem fins lucrativos, criada por particulares, para atuar em áreas que se configuram como atividades não exclusivas do Estado. A qualificação como Oscip permite que a entidade se credencie para celebrar parcerias com órgãos governamentais, embora não exista nenhuma garantia de que isso venha a ocorrer. A justificativa para a proposição do referido modelo consiste na criação de uma alternativa "mais ágil e menos burocrática de transferência de recursos" (Torres, 2007: 80) a essas organizações, comparativamente ao convênio, tradicionalmente usado com tal finalidade.

No caso das Oscips, ainda que a legislação federal aplique-se aos governos subnacionais, alguns estados e municípios também vêm editando legislação própria sobre a matéria. De acordo com estudo da Seges (Brasil, 2010), dez estados e 16 municípios haviam promulgado, até 2008, lei ou norma específica sobre Oscip. No referido ano, existiam 5.050 entidades qualificadas pelo poder público nas três esferas de governo, em sua ampla maioria, 96,2\% do total, pelo governo federal. No entanto, apenas uma pequena fração conseguira celebrar parceria com o poder público. Das 4.856 entidades qualificadas pelo governo federal, 73 tinham contratos com o governo federal, e outras seis com estados e municípios, representando $1,6 \%$ do total. No que toca às entidades qualificadas por estados, 15 das 167 existentes, representando 9,0\% do total, tinham parcerias celebradas, quase todas com o governo mineiro. Já no caso dos municípios, nenhuma das 27 entidades por eles qualificadas tinha parceria celebrada. No balanço geral, tão somente 1,8\% das Oscips existentes à época contavam com parceria com a administração pública. Por sua vez, o número de parcerias celebradas alcançava 283 (Brasil, 2010), com uma média de 3,0 contratos por Oscip.

Como no caso das OSs, a adoção do modelo das Oscips tem se processado sem o adequado aparelhamento da administração pública para zelar pela qualidade do serviço prestado pela entidade contratada, como mostra relatório de auditoria realizado pela Controladoria-Geral da União (CGU) em 25 termos de parceria celebrados pelo MJ com Oscips, referentes ao período de 2008 a 2011. Tal auditoria encontrou impropriedades em 21 dos 25 termos auditados, envolvendo problemas variados, como execução parcial das metas e objetivos propostos, pagamentos indevidos, ausência

\footnotetext{
${ }^{12}$ Para fins de ilustração, o governo do estado do Rio de Janeiro promulgou legislação referente à matéria em 2009, e o de Rondônia o fez em 2011. O mesmo se passa na esfera dos municípios, dentre os quais o Rio de Janeiro.

${ }^{13}$ Isomorfismo mimético consiste na reprodução, por uma dada organização, de práticas adotadas por organizações similares, tomando-as como adequadas, sem uma preocupação mais efetiva com os resultados e as consequências da escolha feita.
} 
de comprovação de bens adquiridos e contratações de serviços com irregularidades, dentre outros. Tão ou mais importante, a CGU associou as irregularidades constatadas à fragilidade e estruturação inadequada dos órgãos responsáveis pela parceria, no âmbito do MJ, para o desempenho das atividades de supervisão e fiscalização das atuações das Oscips (Brasil, 2014b). Não se pode esperar situação distinta nos níveis subnacionais de governo, cujas burocracias são, reconhecidamente, menos profissionalizadas que a federal.

O quantitativo relativamente modesto de parcerias celebradas por Oscips revela que este arranjo organizacional ainda apresenta um alcance limitado como alternativa de desconcentração da gestão na prestação de serviços públicos. Tal resultado, contudo, parece não influenciar a disposição de novas entidades em obter a qualificação. De acordo com dados do MJ, o número de entidades qualificadas pelo governo federal somava, em 2012, um total de 6.565 Oscips, com um crescimento de 35,2\% em relação ao total existente em 2008.

Ainda que a evolução do número de entidades qualificadas como Oscip sinalize a institucionalização do modelo, as relações do setor público com entidades privadas sem fins lucrativos por meio de convênios ${ }^{14}$ não apenas mantêm-se muito expressivas como apresentam trajetória ascendente ao longo dos anos mais recentes. Segundo Lopez e Bueno (2012), os recursos transferidos pelo poder público às entidades sem fins lucrativos experimentaram uma variação real da ordem de 96,3\% entre 2002 e 2009. O crescimento é comum a todos os níveis de governo, e é mais expressivo no nível local, onde alcança $156,7 \%$ no período.

Repetem-se aqui, em escala ainda mais ampliada, as deficiências na capacidade técnica e operacional para gerenciar a relação contratual envolvida no repasse de recursos por meio de convênios e instrumentos congêneres, o que se evidencia em fiscalizações realizadas pelo TCU. É ilustrativo, a esse respeito, o relatório do acórdão 3.025/2010-Plenário, prolatado ao final de 2010, que trata de transferências voluntárias do governo federal a organizações não governamentais. Nele é destacado o desaparelhamento da administração pública federal, em termos de recursos materiais, humanos e tecnológicos, para o bom desempenho de suas atribuições, enquanto concedente, relativas a todas as fases do processo, que vão da proposição e formalização do convênio à análise da prestação de contas dos recursos repassados, passando pela fiscalização e acompanhamento das atividades, objetivos e metas acordadas. Em decorrência dessa fragilidade, de natureza sistêmica, materializa-se, na aplicação dos recursos pelas entidades convenentes, toda a sorte de ilícitos que as falhas no gerenciamento do convênio permitem. São constatações e conclusões que podem ser estendidas ao gerenciamento de convênios nos níveis subnacionais de governo (TCU, 2014a).

Como as terceirizações, as joint ventures não são fenômeno novo no país. A prestação de serviços públicos por entidades privadas remonta ao Império. Ao longo do tempo, o Estado brasileiro organizou as atividades setoriais sob diferentes modalidades, combinando a prestação direta do serviço, por empresa estatal, com a exploração por empresas privadas ou de economia mista, mediante concessão do poder público. Esse arranjo é reafirmado pela CF 1988 que, seguindo a esteira dos textos

\footnotetext{
${ }^{14}$ No caso do governo federal, o convênio aplica-se também a Oscips. No entanto, o repasse a esse tipo de entidade é relativamente pouco expressivo no conjunto de entidades sem fins lucrativos, representando $10 \%$ do total no período 2003-2011, conforme Lopes e Barone (2013).
} 
constitucionais anteriores, estabeleceu os princípios básicos do regime de concessão e permissão de serviços públicos, em que se destaca o imperativo da licitação. Para dar cumprimento ao ditame constitucional, que previa a elaboração de legislação dispondo sobre a concessão e permissão de serviço público, foram editadas as leis n. 8.987/1995 e n. 9.074/1995, ${ }^{15}$ cujas normas têm âmbito nacional, aplicando-se, portanto, a estados e municípios.

Seguindo a trajetória internacional, de retroação da intervenção direta do Estado na economia, a concessão da prestação de serviços públicos a empresas privadas volta a ganhar força no país a partir dos anos 1990. Nesse contexto, é lançado, no governo Collor, o Programa Nacional de Desestatização, por meio da lei n. 8.031/1990, que se inicia pela privatização de empresas nos setores de siderurgia, fertilizantes e petroquímica. A partir do primeiro governo Fernando Henrique Cardoso, o Programa Nacional de Desestatização entra em nova fase, na qual se confere maior prioridade à privatização como instrumento da política de ajuste fiscal com vistas à estabilização macroeconômica. A disposição renovada de levar em frente a redução das atividades empresariais do setor público se manifesta na criação, em 1995, do Conselho Nacional de Desestatização e no relançamento do Programa Nacional de Desestatização, com a edição da lei n. 9.491/1997, que revoga a lei n. 8.031/1990. A agenda privatizante inclui os setores de eletricidade, telecomunicações e transportes, ${ }^{16}$ alargando seu alcance para os governos estaduais. A partir do primeiro mandato de Lula, as concessões passam a ser movidas principalmente pela dificuldade na realização de investimentos em infraestrutura econômica advinda da persistência de uma política fiscal restritiva, comprometida com a obtenção de elevados superávits primários como suporte à estabilização monetária (Oliveira, 2012). Sem perspectivas de mudanças mais expressivas no campo fiscal, o cenário que se desenha é a intensificação das concessões, envolvendo o alargamento do escopo dos serviços prestados com base nas premissas do mercado.

Esse contexto de restrição fiscal impulsiona também a discussão sobre o uso das PPPs no país, que começa a ganhar fôlego em 2002 (Brito \& Silveira, 2005), e é regulamentado, de forma pioneira, pelo governo de Minas Gerais, em 2003. ${ }^{17}$ Outros estados, como São Paulo, Santa Catarina, Goiás e Ceará, seguem a iniciativa do governo mineiro e também se antecipam ao governo federal, promulgando legislações estaduais sobre a matéria em 2004. A regulamentação no âmbito federal ocorre ao final de 2004, o que se faz por meio da lei n. $11.079 .{ }^{18}$ O modelo brasileiro de PPP configura-se como uma espécie de alargamento da concessão, prevendo a possibilidade do ente estatal de se responsabilizar pela cobertura de parte da remuneração do parceiro privado, em complemento às receitas advindas da cobrança de tarifa ao usuário do serviço, ou de o ente estatal constituir o usuário direto ou indireto do serviço, responsabilizando-se integralmente pela remuneração do parceiro privado, dando forma, respectivamente, às denominadas concessões patrocinada e administrativa.

\footnotetext{
${ }^{15}$ Alteradas por diversas leis posteriormente editadas.

${ }^{16}$ As privatizações da prestação de serviços levaram à redefinição de seus marcos regulatórios, a exemplo da lei n. 9.427/1996, relativa aos serviços de energia elétrica, e da lei n. 9.472/1997, relativa aos serviços de telecomunicações.

${ }^{17}$ Lei n. 14.868, que dispõe sobre o Programa Estadual de Parcerias Público-Privadas.

${ }^{18}$ A partir de sua promulgação, alguns dispositivos das legislações estaduais que a antecederam, como a de Minas Gerais, tiveram que ser tacitamente revogadas por contrariarem a regulamentação nela expressa.
} 
Depois de regulamentada, a PPP "passou por um longo período sem aplicação efetiva" (Belsito \& Viana, 2013: 136), para ganhar impulso nos últimos anos da década passada, especialmente nas esferas subnacionais de governo. De acordo com informações do Ministério do Planejamento, Orçamento e Gestão (MPOG), 22 estados e o Distrito Federal já dispunham de legislação própria sobre a matéria, em 2010. O número de contratos assinados alcançava, então, um total de 17, distribuídos por seis estados e Distrito Federal. Progressivamente, o processo se estende aos governos locais, com destaque para as capitais e municípios das regiões Sul e Sudeste.

A despeito do quantitativo ainda relativamente modesto de contratos de PPPs celebrados no Brasil, a combinação da pressão pela realização de investimentos na expansão e melhoria da prestação de serviços públicos, pelo lado da demanda, com as limitações na capacidade de gasto do setor público, nas diferentes esferas de governo, pelo lado da oferta, tende a impulsionar a utilização do modelo. A adoção do Procedimento de Manifestação de Interesse (PMI), ${ }^{19}$ que reproduz, no país, instrumento usual no cenário internacional, por meio do qual a administração pública busca orientar a participação da iniciativa privada na estruturação e projetos de parceria de PPPs, aponta nessa direção. Balanço realizado pelo PPP Brasil (2012), mostra que, entre 2007 e 2012, foram publicados 73 PMIs no âmbito dos governos estaduais, dos quais 71\% do total referiam-se aos anos de 2011 e 2012. Esse incremento acelerado do lançamento de PMIs nos anos mais recentes, ainda que nem todos venham a se transformar em PPP, é um claro indicativo do crescente interesse governamental na parceirização com a iniciativa privada.

O espraiamento da percepção da PPP como alternativa para ampliar o espaço orçamentário na realização de investimentos em infraestrutura econômica e social, sustentado no isomorfismo institucional, deve levar um conjunto cada vez mais amplo de estados e municípios a explorar ao máximo, dentro dos limites institucionais atualmente estabelecidos, ${ }^{20}$ as possibilidades de uso do instrumento. Nesse esforço de atrair o interesse da iniciativa privada, os governos subnacionais vêm recorrendo a projetos de escopo muito variado. Como mostram as iniciativas setoriais já lançadas, os projetos mobilizados pelos governos subnacionais não se atêm às áreas mais convencionais para fins de concessão, especialmente transporte e saneamento básico, que comportam o uso da concessão patrocinada, avançando também em áreas como saúde e educação, para as quais a concessão administrativa se impõe. No âmbito do governo federal, a prioridade tem sido conferida ao uso da modalidade tradicional de concessão, em investimentos na área de infraestrutura econômica. No entanto, o progressivo esgotamento do estoque de investimentos setoriais com perspectivas mais favoráveis de retorno econômico, à medida que as concessões avançam, deve impulsionar as incursões na direção do uso das PPPs, atualmente ensaiadas em projetos nas áreas de irrigação e de defesa.

Por fim, a figura da agência autônoma, designada no PDRAE como agência executiva, foi regulamentada pela lei n. 9.649/1998, que trata da reorganização do Poder Executivo federal. A qualifi-

\footnotetext{
${ }^{19}$ Regulamentado no âmbito do governo federal pelo decreto n. 5.977/2006, o instrumento é destinado à apresentação de projetos, estudos ou investigações elaborados pela iniciativa privada, tendo em vista a modelagem de PPPs em projetos considerados prioritários pela administração pública, aplicando-se também à modelagem de concessões no formato convencional.

${ }^{20}$ Originalmente definido em $1 \%$ da Receita Corrente Líquida (RCL), o limite permitido de despesas em pagamento de contratos de PPP foi elevado, no caso de estados e municípios, para 3\% da RCL pela lei n. 12.024/2009 e, pouco depois, para 5\% da RCL, por força da lei n. 12.766/2012.
} 
cação como agência executiva, contudo, suscitou reduzido interesse nas autarquias e fundações da administração federal. Esse novo formato organizacional encontrou maior ressonância sob a forma de agência reguladora, o que reflete o processo de desestatização formalmente desencadeado nos anos 1990. Inspiradas no modelo de regulação americano, as agências reguladoras, em trajetória distinta das agências executivas, vêm adquirindo crescente institucionalidade na administração pública brasileira. O movimento se inicia com a criação da Agência Nacional de Energia Elétrica (Aneel), em 1996, à qual se seguem a Agência Nacional de Telecomunicações (Anatel) e a Agência Nacional do Petróleo, Gás Natural e Biocombustíveis (ANP), ambas datadas de 1997, ${ }^{21}$ e se estende também ao nível subnacional de governo. ${ }^{22}$

Do exame empreendido emergem dois movimentos principais de reconfiguração dos arranjos organizacionais da administração pública brasileira, cuja dinâmica mais recente sinaliza para uma trajetória de progressiva consolidação. O primeiro envolve parcerias com entidades sem fins lucrativos e congêneres, e o segundo, parcerias com empresas privadas. Em ambos os casos, são movimentos que não deslocam ou substituem formas convencionais de relação do setor público com tais entidades e empresas - respectivamente, o convênio e a concessão - mas as complementam, implicando uma maior diferenciação do tecido organizacional responsável pela prestação de serviços públicos à sociedade. A delegação da gestão a entidades sem fins lucrativos, o que inclui arranjos como as OSs e as Oscips, aplica-se à prestação de serviços na área social e tem sido utilizada pelos governos subnacionais como uma alternativa à execução direta da atividade, que, embora não necessariamente mais eficiente, reduz a pressão pela expansão dos respectivos aparatos técnicos e administrativos.

Por sua vez, a delegação da gestão a empresas privadas, lastreada no instrumento da concessão, cujo escopo vem sendo alargado com a adoção das PPPs, aplica-se à prestação de serviços nas áreas de infraestrutura econômica e social, e tem sido crescentemente utilizada pelos governos, tanto federal quanto estadual e local, como uma alternativa de financiamento, em face das limitações no tocante à capacidade de realizar investimentos com recursos próprios. Não custa lembrar, no entanto, que a decisão de delegar meramente altera a natureza das atividades desempenhadas pelo governo, não o eximindo de suas responsabilidades. Delegar envolve contratar, demandando capacidade de negociar e monitorar o contrato que, como visto, revela insuficiente aparelhamento na administração pública brasileira, notadamente na esfera subnacional de governo.

\section{Descentralização político-administrativa e o papel dos municípios}

Descentralização constitui um termo empregado em sentidos variados, que vão desde a transferência da prestação de serviços para empresas privadas ou organizações governamentais até a redistribuição ampla de poder entre níveis distintos de governo, passando pela delegação de funções e responsabilidades entre órgãos ou unidades de uma mesma esfera de governo (Pollitt, 2007). Para os

\footnotetext{
${ }^{21}$ As mencionadas agências foram instituídas, respectivamente, pelas leis n. 9.427/1996, n. 9.472/1997 e n. 9.478/1997. Posteriormente, outras sete agências foram instituídas e uma oitava - a Agência Nacional de Mineração (ANM) encontra-se em processo de criação.

${ }^{22}$ A título de ilustração, a Associação Brasileira de Agências de Regulação (Abar) conta, em seu quadro de entidades associadas, com 27 agências reguladoras estaduais e outras cinco municipais.
} 
propósitos aqui pretendidos, restringe-se à aplicação do termo ao campo das relações intergovernamentais, o que remete à redistribuição de poder decisório do nível central para os níveis subnacionais de governo, com destaque para o local.

O exame da questão implica considerações acerca de duas questões principais, que conferem materialidade ao padrão das relações estabelecidas entre os diferentes níveis de governo. O primeiro relaciona-se com a forma como se dá a redistribuição de responsabilidades, o que é particularmente relevante quando estão envolvidas funções ou competências partilhadas. O compartilhamento de funções demanda o desenho de arranjos institucionais com vistas a articular a atuação dos diferentes níveis de governo, sem o qual há um risco não desprezível de fragmentação excessiva e dispersão de esforços na implementação de uma dada política. O segundo refere-se à redistribuição financeira, envolvendo mecanismos de transferência de recursos do nível central para os governos subnacionais, de forma a assegurar padrões mínimos de qualidade nos serviços prestados à população.

Ainda que os argumentos acerca da descentralização sejam, conforme Pollitt (2007: 372), "tão antigos como o estudo da administração pública", o tema persiste complexo e controverso (Przeworski, 1999), sinalizando a existência de posições favoráveis e contrárias à mesma. Os aspectos positivos comumente associados à descentralização remetem, em geral, ao aumento da eficiência e efetividade na alocação dos recursos públicos com vistas à provisão de bens e serviços à população, na dimensão administrativa, e à maior democratização no exercício da atividade governativa, na dimensão política. Por sua vez, os aspectos negativos apontam na direção oposta, ou seja, riscos de ineficiência alocativa, na dimensão administrativa, e de fragilização do controle da sociedade sobre o governo, na dimensão política.

A descentralização potencializa ganhos de eficiência e de efetividade ao favorecer um melhor ajustamento da oferta dos bens ou serviços públicos às preferências e necessidades da população neles interessada, além de facilitar a experimentação e a introdução de inovações (Pollitt, 2007; Beramendi, 2009). Quanto ao primeiro aspecto, o ponto relevante é a possibilidade da adoção de soluções não padronizadas na provisão do bem público, incorporando uma avaliação mais criteriosa e realista, baseada nas preferências dos usuários, dos custos e benefícios sociais de diferentes alternativas para lidar com a questão. No tocante ao segundo aspecto, os governos locais seriam compelidos, pela maior pressão da demanda da população, a usar a autonomia decisória de que dispõem para buscar soluções criativas e inovadoras capazes de refletir as peculiaridades de suas respectivas jurisdições (Abrucio, 2006).

O pressuposto básico que orienta a percepção de que a descentralização influencia positivamente a democracia é o de que a maior aproximação entre governantes e governados favorece o controle social da população sobre o governo, aumentando não só a responsividade como também a transparência das ações do poder público. $\mathrm{O}$ fato de a gestão da coisa pública ficar mais próxima da população facilita o encaminhamento das demandas ou reivindicações de interesses constituídos da sociedade ao governo, ao mesmo tempo que aumenta a probabilidade de difusão de informações de interesse coletivo e de instituição de canais mais efetivos de fiscalização da atividade governativa. Outra linha de interpretação enfatiza a descentralização como instrumento para o desenvolvimento 
de uma cultura cívica direcionada à busca de soluções para os problemas coletivos ancoradas em organizações da sociedade civil e, portanto, menos dependentes do Estado.

No entanto, descentralizar possui, reconhecidamente, limites administrativos e políticos, podendo apresentar efeitos perversos caso alguns requisitos não se façam presentes na estruturação organizacional da instância local de governo e nos arranjos sociais e institucionais prevalecentes em sua respectiva jurisdição. A literatura destaca dois tipos principais de problemas que podem influenciar e, no extremo, comprometer os resultados esperados da descentralização, dando suporte a argumentos a favor da centralização. O primeiro refere-se a riscos de ineficiência econômica e social na alocação de recursos, envolvendo questões atinentes tanto à formulação quanto à implementação de políticas públicas. O segundo guarda relação com a capacidade de organização e mobilização política das comunidades locais, que se reflete na qualidade do controle social sobre o governo.

Os possíveis ganhos de eficiência advindos da descentralização supõem a existência de capacidade técnica e de mobilização de recursos das administrações locais compatíveis com o desempenho das funções que lhes competem. A extensão ou abrangência da descentralização deve considerar as distintas exigências de capacidade gerencial e financeira das diferentes atribuições do poder público e as capacidades efetivamente existentes nos níveis locais de governo, de forma a evitar padrões muito desiguais na quantidade e, principalmente, na qualidade da provisão de bens e serviços à população.

Como observa Pollitt (2007), os governos locais se defrontam com maior dificuldade no tocante a recrutar e reter uma massa crítica de profissionais especializados, comparativamente ao nível central de governo. Um dos principais riscos é a ausência de padrões mínimos na provisão de serviços sociais básicos à população, penalizando, regra geral, as comunidades mais pobres, as quais não podem prescindir da atuação do poder público. Sobre a questão, Pollitt (2007: 381) pondera que a "centralização, sob a forma de padronização, leva a maior equidade". Seguindo com o autor, "todos os cidadãos, em circunstância similar, recebem o mesmo serviço". Ao lado disso, a descentralização pode criar dificuldades na coordenação e no controle da implementação de políticas públicas partilhadas por diferentes níveis de governo.

A principal contribuição da descentralização à democracia, destacada pela literatura, que se traduz na facilitação à participação política, instrumentalizando "formas mais efetivas de controle sobre a agenda e sobre as ações de governo" (Arretche: 1996: 6), por sua vez, não é linear nem automática. Ao contrário, descentralizar pode ter efeitos adversos, favorecendo a adoção de padrões arcaicos de condução da atividade governativa no nível local, lesivos aos interesses da coletividade. Entre tais efeitos, podem ser relacionados a maior porosidade da administração pública à inserção de interesses particularistas, com o risco não desprezível de captura do poder político por determinados grupos que se alternam, ou não, no comando do governo, bem como a maior propensão à cooptação e obtenção de apoio político por meio de práticas de natureza clientelista.

Depreende-se, das considerações anteriores que, para prevalecerem os efeitos positivos atribuídos à descentralização, faz-se necessário o preenchimento de determinados requisitos mínimos, quer na dimensão administrativa quer na dimensão política das instâncias locais de governo. Na esfera administrativa, o ponto saliente consiste na criação de uma burocracia profissionalizada, capaz de 
assegurar maior agilidade e eficiência à gestão pública e de dar respostas de melhor qualidade às demandas da população. Na esfera política, é indispensável a construção de "instituições cuja natureza e cujas formas de atuação sejam compatíveis com os princípios democráticos que norteiam os resultados que se espera produzir" (Arretche, 1996: 6), ou seja, que não se prendam apenas à intenção ritualística de mero formalismo burocrático.

A descentralização brasileira do período contemporâneo não é pautada primariamente por razões relacionadas à busca de maior eficiência alocativa na prestação de serviços à população, ainda que considerações desta natureza sejam tacitamente observadas ao longo de sua implementação. Trata-se, como já mencionado, de um empreendimento de fundamentação política, articulado à redemocratização, cujo marco é a promulgação da CF 1988. O novo texto constitucional promove um redesenho no arranjo federativo do país, no qual o município é incorporado, juntamente com os estados, como parte integrante da federação (Souza, 2005). Essa descentralização se traduz na ampliação da autonomia fiscal, política e administrativa dos municípios, ao lado do alargamento de seus papéis e competências, em que se destaca a definição de funções partilhadas na área das políticas sociais.

Os impactos mais imediatos da descentralização preconizada pela CF 1988 se deram no campo fiscal, já que se ancoravam em dispositivos autoaplicáveis, que prescindiam de regulamentação por legislação infraconstitucional para a entrada em vigor. De fato, o novo texto constitucional patrocinou significativo alargamento da base de financiamento dos municípios, tanto pela ampliação de seu poder de taxação quanto, e principalmente, pela elevação do volume de repasse de transferências compulsórias de recursos por parte dos governos estadual e federal (Affonso \& Silva, 1996; Arretche, 2000; Oliveira, 2003). Esse incremento de receita, no entanto, não se fez acompanhar da concomitante assunção de funções ampliadas na gestão de políticas sociais pelos governos locais, também objeto de intenções descentralizantes. A despeito de os municípios passarem a dispor de uma maior capacidade de financiamento e, por consequência, de assumirem novas e ampliadas funções, a descentralização no campo social será gradativa, exigindo um esforço de engenharia institucional comandado pelo governo federal.

O processo é deflagrado nos anos 1990 e se aprofunda na década seguinte, quando as relações intergovernamentais se intensificam e adquirem maior complexidade. Tal processo não envolve apenas a transferência de responsabilidades ou atribuições, mas a construção mesma da política pública, uma vez que o sistema de proteção social brasileiro prevalecente até a promulgação da CF 1988, descrito por Arretche (2000: 46) como um "conjunto disperso, fragmentado, com reduzidos índices de cobertura e fragilmente financiado de iniciativas governamentais na área social", teve sua concepção profundamente alterada pelo novo texto constitucional. A área da saúde ilustra bem a questão, com a criação do Sistema Único de Saúde (SUS) por determinação constitucional. E é exatamente na área da saúde que começa a tomar forma o protagonismo do governo federal como normatizador e coordenador das políticas sociais no país.

O passo inicial para a regulamentação do SUS é dado pela lei n. 8.080/1990, que estabelece as atribuições dos diferentes níveis de governo no tocante a competências e gestão. Em complemento à lei n. 8.080, edita-se a lei n. 8.142/1990, que define as formas de transferência de recursos entre as esferas de governo, com a constituição do Fundo Nacional de Saúde e a especificação das condições 
para acesso ao mesmo por parte dos estados e dos municípios, ${ }^{23}$ bem como as formas de participação social na política setorial. No decorrer da década de 1990 e seguintes, o país continua construindo um sistema nacional de saúde, de natureza pública, universal e gratuito, delineado nas leis mencionadas. Esse processo se faz por meio de normas - as Normas Operacionais Básicas (NOBs) e as Normas Operacionais de Assistência à Saúde (Noas) - e de portarias editadas pelo governo federal, o qual se encarrega da formulação da política setorial e da coordenação das ações intergovernamentais no âmbito da mesma.

A regulamentação básica para a descentralização da gestão irá se fundamentar em dois mecanismos principais: a habilitação para assunção de funções e o incentivo ou indução à adesão ao sistema. A habilitação foi introduzida pela NOB-SUS/1991, por meio da qual se verifica a capacidade operacional dos estados e municípios de assumir a implementação de ações da política de saúde em suas respectivas jurisdições. Reconhece-se que a descentralização, como destaca a literatura, não pode prescindir da existência de condições técnicas e operacionais - em termos de estrutura física, organizacional e de recursos humanos - minimamente compatíveis com o desempenho da função ou atividade que se quer descentralizar.

A NOB-SUS/1993 encarregou-se de definir distintas modalidades de habilitação ao SUS, ${ }^{24}$ "as quais supõem graus distintos de responsabilidade sobre a gestão dos serviços" (Arretche, 2000: 206-207), portadores de graus distintos de complexidade. A indução ancora-se em incentivos financeiros, sob a forma de transferências universais condicionadas, em que o acesso a recursos disponibilizados pela política federal requer a prévia adesão aos objetivos nela traçados. A esse mecanismo de indução se soma a emenda constitucional n. 29/2000, que determinou gastos mínimos compulsórios em ações de saúde para estados e municípios. ${ }^{25}$ Refletindo os efeitos dos mecanismos de indução, a totalidade dos governos subnacionais - estados e municípios - optou por se integrar ao sistema nacional, no âmbito do qual desempenham ações da política setorial definida pelo governo federal, o que se aplica especialmente aos governos locais. Como salienta Arretche (2012: 163), o uso combinado da autoridade normativa e do poder de gasto permite ao governo federal direcionar a atuação dos governos municipais para "programas de atenção básica à saúde, contratação de médicos, enfermeiros e atendentes de saúde, bem como acesso gratuito a principais medicamentos, cobertura vacinal e atendimento pré-natal", esvaziando, na prática, a autonomia decisória que formalmente os reveste.

A área da assistência social segue, em linhas gerais, a concepção de política pública delineada para a saúde, convergindo para a construção do Sistema Único de Assistência Social (Suas), que se articula em torno da execução descentralizada das atividades e ações da política setorial, cuja formulação geral fica a cargo do governo federal. O marco inicial do processo de regulamentação da gestão da política de assistência social consiste na aprovação da Lei Orgânica da Assistência Social (Loas),

\footnotetext{
${ }^{23}$ Para o acesso aos recursos disponibilizados pelo governo federal, os municípios devem dispor de fundo municipal de saúde, órgão gestor, conselho de saúde e plano de saúde, entre outros requisitos.

${ }^{24}$ Posteriormente alterada pela NOB-SUS 01/96 e pelas Noas-SUS/2001 e 2002.

${ }^{25}$ No caso dos estados, a fração da receita destinada a gastos em saúde começa com o patamar de $7 \%$ em 2000 para alcançar $12 \%$ a partir de 2004; no caso dos municípios, a fração sobe dos mesmos $7 \%$ da receita em 2000 para $15 \%$ a partir de 2004.
} 
em 1993, que define o município como instância privilegiada da execução de ações e serviços assistenciais, seja de forma direta seja por meio da celebração de convênios com entidades assistenciais. Nos termos da Loas, cabe ao governo federal o "papel de financiador e normatizador, e aos municípios o papel de formulador e executor das políticas no plano local", com atribuições residuais reservadas aos estados (Arretche, 2000: 175). Para o exercício de seu papel de financiador, o governo federal instituiu, de forma similar à política de saúde, o Fundo Nacional de Assistência Social, ${ }^{26}$ cujo acesso requer o preenchimento de um conjunto de requisitos técnicos e operacionais, que contempla, no caso dos municípios, a criação de fundo, conselho, plano e órgão gestor de assistência social.

Num processo lento de regulamentação, o aprimoramento e o adensamento da política setorial somente vão se dar na década seguinte, com a edição da NOB-Suas/2005, ${ }^{27}$ que dispôs sobre os níveis de gestão, além de definir critérios mais objetivos e transparentes de financiamento e repasse de recursos. No entanto, a efetiva estruturação do Suas ocorre, a rigor, com a promulgação da lei n. 12.435/2011, que garante o ordenamento jurídico para as diretrizes de descentralização e participação da sociedade civil na concepção, gestão e controle da política setorial. A mencionada legislação define responsabilidades e competências; reafirma o cofinanciamento por meio de transferências automáticas entre os fundos setoriais e da alocação de recursos próprios dos entes federados nestes fundos; e organiza as ações pelo grau de complexidade e natureza do atendimento em serviços de proteção social básica e especial. ${ }^{28}$ De acordo com dados do Ministério do Desenvolvimento Social e Combate à Fome (MDS), a quase totalidade dos municípios havia aderido ao Suas em 2012.

No caso da política habitacional, a CF 1988 estabelece também a competência comum dos diversos entes federados para promover programas na área, ainda que sem maiores indicações de responsabilidades e competências. E, diferentemente das políticas de saúde e assistência social, cujos marcos legais foram aprovados ainda nos anos 1990, a regulamentação da política setorial irá se processar mais tardiamente, já nos anos 2000. Sua estruturação se concretiza com a promulgação da lei n. 11.124/2005, que cria o Sistema Nacional de Habitação de Interesse Social (SNHIS) e o Fundo Nacional de Habitação de Interesse Social (FNHIS), além de instituir o conselho gestor do FNHIS. ${ }^{29} \mathrm{O}$ arcabouço normativo segue o molde da legislação das políticas sociais. Assim, para acessar os recursos do FNHIS, governos subnacionais devem criar conselhos e órgãos específicos, ao lado de instrumentos como cadastros, planos e fundos setoriais. No que diz respeito aos municípios, pesquisa coordenada por Arretche (2013) mostra, ao mesmo tempo, a força da legislação em induzir a adesão dos governos locais ao sistema e a dificuldade com as quais estes se defrontam em cumprir os requisitos administrativos e operacionais nela especificados.

\footnotetext{
${ }^{26}$ O Fundo Nacional de Assistência Social foi regulamentado pelo decreto n. 1.605/1995.

${ }^{27}$ Trata-se da primeira NOB que versa sobre o Suas, instituído na Política Nacional de Assistência Social, de 2004.

${ }^{28} \mathrm{~A}$ proteção social básica está voltada para a prevenção de situações de vulnerabilidade e risco social, tendo, como unidade referencial para a prestação do serviço, o Centro de Referência de Assistência Social (Cras). A proteção social especial orienta-se para a reconstrução de vínculos familiares e comunitários, bem como para a defesa de direitos, tendo, como unidade referencial para a prestação do serviço, o Centro de Referência Especializado de Assistência Social (Creas).

${ }^{29} \mathrm{~A}$ referida lei considera dois subsistemas - o de habitação de interesse social - correspondente às faixas de renda familiar de 0 a 3 e 3 a 5 salários mínimos - e o de habitação de mercado.
} 
Em 2012, a disposição de integrar o sistema alcançava 96,9\% dos municípios, enquanto a parcela daqueles que dispunham de fundo, conselho e plano setorial era de, respectivamente, 71,7\%, 68,2\% e $11,4 \%$ do total.

Outros avanços importantes promovidos pelo governo federal referem-se às áreas de saneamento ambiental, transporte e mobilidade urbana. A responsabilidade pelo delineamento das políticas setoriais ficou a cargo do Ministério das Cidades, criado em 2003. Em meados de 2004, a política urbana nas áreas mencionadas encontra-se consolidada em suas premissas gerais, objetivos e programas, e, nos anos seguintes, estabelecem-se os respectivos marcos regulatórios. O processo se inicia pela Política Nacional de Saneamento Básico, instituída pela lei n. 11.445/2007 e regulamentada pelo decreto n. 7.217/2010. De acordo com a regulamentação, a elaboração de planos setoriais pelos governos subnacionais passa a ser condição obrigatória para acesso a recursos federais a partir de 2014, sendo prescrito também o controle social por meio de órgão colegiado.

A Política Nacional de Resíduos Sólidos é objeto da lei n. 12.305/2010, cuja regulamentação se faz pelo decreto n. 7.404/2010. Como no caso da política de saneamento básico, a regulamentação prevê a elaboração de planos de resíduos sólidos urbanos como condição de acesso a recursos federais para a área, a partir de 2012, conferindo prioridade, na acessibilidade, a municípios que fizerem a opção por solução consorciada. Mais recentemente, o governo federal institui a Política Nacional de Mobilidade Urbana por meio da lei n. 12.587/2012. Nela, fica estabelecida a obrigatoriedade da elaboração de planos municipais de mobilidade urbana para municípios de população acima de 20 mil habitantes, num prazo de até três anos após sua edição, condicionando, como nas demais políticas setoriais, o acesso a recursos federais à sua existência.

A área da educação apresenta trajetória distinta das demais políticas sociais no tocante à descentralização, a começar pelo fato de a oferta de ensino fundamental já ser de responsabilidade de estados e municípios anteriormente à CF 1988. O novo texto constitucional reafirmou o ensino fundamental como função de competência comum desses entes federados, "estabelecendo apenas que os governos municipais deveriam dar prioridade" ao mesmo (Arretche, 2012: 166). Ao lado disso, estabeleceu vinculação de receita disponível de estados e municípios a gastos nas atividades de ensino, destinando $25 \%$ do total com tal finalidade. Além da função precípua de manutenção da rede federal de ensino superior e apoio à pós-graduação, coube ao governo federal, no caso da educação básica, apenas um papel supletivo no financiamento setorial, atuando como financiador de programas de merenda escolar e de "construção e capacitação das unidades escolares" (Arretche, 2012: 167), dentre outras ações.

Esse arranjo institucional, contudo, revelou-se insuficiente para fomentar a universalização e o adequado funcionamento do ensino fundamental obrigatório, consoante as diretrizes da Lei de Diretrizes e Bases da Educação Nacional - lei n. 9.439/1996 -, desembocando na criação do Fundo de Manutenção do Ensino e Valorização do Magistério (Fundef).$^{30} \mathrm{O}$ Fundef sinaliza a disposição do governo federal em assumir o papel de normatizador e coordenador da política setorial, deixando

\footnotetext{
${ }^{30} \mathrm{~A}$ instituição do Fundef se ancora na promulgação da emenda constitucional n. 14/1996, na lei n. 9.424/1996 e no decreto n. 2.264/1997 (Oliveira, 2003).
} 
a cargo dos governos subnacionais sua execução, ${ }^{31}$ na linha do modelo aplicado às demais áreas da política social. Na década seguinte, o Fundef, que vigorou de 1998 a 2006, foi substituído pelo Fundo de Manutenção e Desenvolvimento da Educação Básica e de Valorização dos Profissionais da Educação (Fundeb). ${ }^{32}$ Conforme Arretche (2012), o Fundeb adota regras similares às do Fundef. ${ }^{33}$ Suas principais inovações são a ampliação da cobertura para o ensino básico e a elevação de gasto do governo federal, que passa a assumir maiores responsabilidades no financiamento da política setorial.

Assim, induzida e comandada pelo governo federal, a descentralização revela-se um dos processos mais marcantes da gestão pública brasileira do período contemporâneo, que vem redesenhando a forma como os serviços públicos são prestados à população. Tal processo fica evidenciado nas profundas transformações transcorridas na estrutura do emprego público, na direção à sua municipalização. De uma participação quase residual em 1950 - 15,0\% do total -, o emprego público municipal experimenta aumentos sistemáticos de sua representatividade a partir dos anos 1970 e, especialmente, desde a promulgação da CF 1988, para se tornar majoritário na segunda metade da década de 1990, alcançando 42,0\% do total em 1999. Atualmente, os municípios são responsáveis por mais de 50,0\% do emprego público no país (Pessoa, 2003; Marconi, 2010).

Esse crescimento acelerado da representatividade do emprego público municipal denota que os governos locais estão buscando se aparelhar administrativamente para cumprir os novos papéis e responsabilidades que lhes foram atribuídos no texto constitucional. De fato, o incremento de mais de dois milhões de empregados no setor público ocorrido entre 1993 e 2007 se deve basicamente à expansão do emprego no nível local. Enquanto o emprego nos governos federal e estadual pouco variou no período - respectivamente, 5,5\% e 4,1\% -, o emprego municipal experimentou uma variação da ordem de $81,3 \%$ do total (Marconi, 2010). Dados mais atualizados do Instituto Brasileiro de Geografia e Estatística (IBGE) indicam que o emprego municipal continuou se expandindo, para alcançar 6.280.213 pessoas em 2012 - um incremento de 20,6\% em relação a 2007 (IBGE, 2012).

As informações referentes ao emprego público no nível municipal, ao mesmo tempo que atestam o êxito do governo federal em promover a adesão dos governos locais à descentralização no campo das políticas sociais, lançam luz sobre os desafios com os quais estes se defrontam quanto à construção de estruturas administrativas profissionalizadas para lidar com as crescentes responsabilidades e atribuições na prestação de serviços à população. Essa questão ganha particular relevância no contexto de limitada flexibilidade fiscal que marca a administração pública brasileira, em especial os níveis subnacionais de governo. Interessa destacar aqui, especificamente, o fato de o incremento da demanda por gastos dos municípios na área social, advindo da dinâmica descentralizante, não se fazer acompanhar de concomitante aumento em sua capacidade de financiamento. Embora seja

\footnotetext{
${ }^{31}$ O Fundef envolve uma espécie de minirreforma (Oliveira, 2003; Arretche, 2012), destinando, automaticamente, $15 \%$ das receitas de estados e municípios para um fundo estadual, redistribuídas, no interior de cada estado, entre governos estadual e municipais, de acordo com o respectivo número de matrículas no ensino fundamental oferecidas anualmente.

${ }^{32} \mathrm{O}$ Fundeb foi criado pela emenda constitucional n. 53/2006 e regulamentado pela lei n. 11.494/2007 e pelo decreto n. $6.253 / 2007$.

${ }^{33}$ Cabe destacar o aumento, de $15 \%$ para $20 \%$, da parcela das receitas vinculadas que são destinadas ao fundo.
} 
nítido o ganho de receita dos municípios no período determinado pelas mudanças introduzidas pela CF 1988, o processo perde fôlego nos anos mais recentes, com a participação dos governos locais estabilizando-se em torno do patamar de $20 \%$ da receita líquida total do setor público (Khair, 2013).

A despeito das dificuldades de natureza administrativa e financeira que marcam sua trajetória, a descentralização na área social parece um caminho sem volta na realidade brasileira. Os notáveis avanços na normatização das políticas setoriais, ainda que suscetíveis a novos aprimoramentos, como historicamente vêm ocorrendo, tendem a lhe conferir um grau de institucionalização de difícil reversão. Se isso é verdade, também o é a necessidade de se avançar além da indução da adesão dos municípios às políticas desenhadas pelo governo federal. A adesão não se transmuta automaticamente em adequada capacidade de gestão nem sinaliza sua efetiva existência. Assim, para que a descentralização possa proporcionar ganhos de eficiência na prestação de serviços à população e incrementos da democratização no exercício do poder público - virtudes que lhe são convencionalmente atribuídas -, há que se enfrentar o déficit de capacidade técnica e gerencial presente na esfera dos governos locais. Tal enfrentamento não se viabiliza sem o protagonismo e o apoio do governo federal. É nessa direção que aponta o lançamento recente do Programa Mais Médicos, ${ }^{34}$ com o objetivo de fortalecer a prestação de serviços de atenção básica à saúde no país, por meio de redução da carência de médicos em regiões consideradas prioritárias para o SUS.

\section{Governança democrática e as instâncias de participação}

O termo governança não é propriamente novo; é utilizado há muito tempo, com fins descritivos, significando "a ação ou forma de governar, isto é, de dirigir, guiar ou regular as condutas ou ações de indivíduos, organizações, nações ou associações multinacionais - públicas, privadas ou ambas" (Lynn Jr., 2012: 49). Sua reintrodução recente se dá com base na literatura anglo-saxônica, em que se destaca o trabalho de Willianson (1979), que tem um forte impacto nas abordagens relativas à relação entre lei e economia e, especificamente, à governança corporativa.

Não há uma abordagem unificada da temática da governança, o que reflete, em particular, as diversas áreas disciplinares e vertentes teóricas que se utilizam do termo. Não se tem, portanto, uma noção única, mas um conjunto não homogêneo de concepções, bem como de aplicações em diferentes domínios ou campos de conhecimento. A adjetivação do conceito - governança local, corporativa, democrática, participativa, regulatória, urbana - ilustra bem a questão, como evidencia a análise de Peters (2012).

Descartando-se efetuar uma revisão do emprego do termo - de suas variações conceituais e de seu potencial analítico, já realizada por diversos autores, como Levi-Faur (2012) -, importa destacar duas perspectivas. A primeira, de cunho normativo ou prescritivo, remete à ideia de "bom governo" e a seus atributos; a segunda, mais afeta ao enfoque aqui pretendido, ilumina analiticamente a dimensão relacional. Nesse sentido, em convergência com diversos autores, Stoker (1998) afirma que a noção de governança teria em vista capturar mudanças ocorridas nos governos e em sua relação com a sociedade, em ressonância com os debates políticos nas democracias ocidentais.

\footnotetext{
${ }^{34}$ O programa foi instituído pela medida provisória n. 621 , de agosto de 2013, convertida na lei n. 12.871, de outubro de 2013.
} 
Na análise de Klinj (2012), relevante para os objetivos deste trabalho, a governança não se refere ao governo tradicional nem ao "bom governo", tampouco às reformas no bojo da NPM. Remete, sim, às mudanças nas relações entre governo e atores visando à coordenação horizontal e a qualidade do processo decisório. $\mathrm{O}$ autor destaca o entrelaçamento da governança com a democracia, na medida em que a primeira tem em vista a inclusão e o envolvimento dos diferentes atores sociais nos processos de formulação e implementação das políticas públicas por meio de novos arranjos e modos de decisão compartilhados. Encampando possibilidades de participação nos processos decisórios, a perspectiva de governança favoreceria a legitimidade democrática, a accountability e a oportunidade de vocalização societária e de sua contribuição para as deliberações.

As linhas mais reflexivas e críticas que abordam a governança contemporânea, como já assinalado por Carneiro e Menicucci (2011), encaminham-se para a dimensão participativa-deliberativa. Desse modo, pode-se identificar um conjunto de trabalhos que ressituam a noção de governança com base na incorporação de elementos das teorias democráticas contemporâneas, em suas correntes de democracia deliberativa e participativa (Fung \& Wright, 2001; Fung, 2003; Klinj, 2012; Lynn Jr., 2012; Fisher, 2012). O núcleo comum desses empreendimentos está na ênfase conferida à participação da sociedade nos processos decisórios como um elemento central na noção de governança.

Também pode ser observado na literatura brasileira o emprego do termo governança democrática ou participativa, mais especificamente em referência à esfera local. Os trabalhos que empregam esse termo voltam-se, em grande parte, para a análise de instituições participativas, sobretudo dos conselhos municipais (Gohn, 2004; Cortes, 2005; Wampler, 2011). A noção de governança tem sido empregada como um recurso analítico, e às vezes retórico, para a abordagem da participação nesses espaços, com o foco privilegiado nos arranjos institucionais estabelecidos e suas consequências.

O ambiente que circunscreve a expansão inicial das experiências de participação institucionalizada no âmbito brasileiro pós1988 marca-se pela emergência de novos atores coletivos societários, pela reestruturação dos seus modelos de intervenção estatal, pelo processo de descentralização e ampliação da autonomia local, pelo alargamento dos direitos sociais e pelas premissas de democratização das relações entre Estado e sociedade. Nesse contexto, a governança democrática ou participativa pode ser associada às formas ampliadas de participação por meio das instituições participativas que foram cunhadas, possibilitando a inclusão política de atores societários nos processos decisórios institucionais. Sem a pretensão de análise das principais instituições participativas, de suas características, alcances e limites, apresenta-se a seguir um panorama sumário da arquitetura participativa no país, enfatizando-se os conselhos e as conferências.

Os conselhos são as instituições participativas mais difundidas, podendo-se considerar que se inscreveram de forma irreversível na gestão pública. É relevante distinguir, dos demais, os conselhos de políticas públicas que têm o papel de gestores de fundos em decorrência de legislação federal. Em caráter obrigatório, há os conselhos de saúde, assistência social, direitos da criança e do adolescente, da educação e de habitação de interesse social. Ao lado desses, há outros conselhos de políticas que não são objeto de exigência legal, como os conselhos de direitos e conselhos temáticos e, ainda, os conselhos de programas. ${ }^{35}$

\footnotetext{
${ }^{35}$ Ver Tatagiba (2002) em seu esforço precursor de distinguir analiticamente os diversos tipos de conselhos.
} 
No âmbito federal, sem distinção de tipologias, Moroni (2009) identifica 64 conselhos, dos quais 13 foram criados no governo Lula - colocando em foco novos temas - e outros nove reestruturados no período. ${ }^{36}$ No âmbito estadual, dados de pesquisa do IBGE permitem constatar a expressão dos conselhos, presentes na totalidade dos estados nos casos dos conselhos de saúde, de assistência social, de educação, de direitos da criança e do adolescente e de habitação, que constituem os casos exigidos para repasse de fundos (IBGE, 2013). Mais além, a totalidade dos estados dispõe de conselhos de cultura, meio ambiente, direitos do idoso e segurança alimentar. Em relação a outros conselhos pesquisados, têm-se os seguintes resultados: conselhos de segurança, em $63 \%$ dos estados; de transporte, 48,1\%; de esporte, $63 \%$; de direitos da pessoa com deficiência, 59,3\%; de promoção da igualdade racial, 37\%; e de direitos de lésbicas, gays, bissexuais, travestis e transexuais, 18,5\% do total. Destacam-se, portanto, ao lado dos conselhos de políticas em seus recortes setoriais ou temáticos, os conselhos de direitos de minorias. O levantamento indica que, do universo de conselhos estaduais, o tempo médio de existência é de 16, 7 anos, posteriores, portanto, à CF 1988. A maioria reuniu-se no ano de referência da pesquisa e tem caráter deliberativo, ao passo que a existência de fundos é uma característica relativamente pouco presente.

No âmbito municipal, pesquisas do IBGE permitem notar a expansão e a diversidade dos conselhos, com destaque para a disseminação mais expressiva dos conselhos gestores das políticas sociais requeridos por legislação federal. Conforme dados de 2001, os conselhos de saúde existiam em 98,5\% dos municípios; os de assistência social, em 91,65\%; de educação, em 91,0\%; e de direitos da criança e do adolescente, em 71,7\%. Os conselhos de habitação, à época ainda não requeridos por legislação federal, apresentavam-se em $11 \%$ dos municípios. Em relação às características básicas do seu desenho institucional, a maioria era deliberativa e paritária e tinha funcionamento regular (IBGE, 2001). Quase uma década depois, em 2009, 97,3\% dos municípios dispunham de conselhos municipais de saúde; 98,1\% dispunham de conselhos de educação; e 97,8\%, de conselhos dos direitos da criança e do adolescente (IBGE, 2009). No caso da assistência social, em 2008, 98,8\% dos municípios tinham essa entidade (IBGE, 2008). A expansão do número de conselhos no caso da habitação social é significativa em virtude da legislação aprovada em 2005, de modo que 42,6\% dos municípios apresentavam conselhos de habitação em 2009, e 58,2\%, em 2011 (IBGE, 2009, 2011).

Em 2001, levantamento do IBGE registrava a ocorrência de outros conselhos de políticas não exigidos em legislação nos municípios brasileiros: 34\%, no caso de conselhos de emprego e trabalho; 29\%, de meio ambiente; $22 \%$, de turismo; $13 \%$, de cultura; $6 \%$, de política urbana; e $5 \%$, de transportes. Notava-se ainda a existência de outros conselhos com ocorrências menos expressivas. Observando-se uma tendência geral de expansão do número de conselhos nos diversos campos setoriais, destaca-se o caso dos conselhos de meio ambiente, presentes em 47,6\% dos municípios em 2009 (IBGE, 2001, 2009).

\footnotetext{
${ }^{36}$ Nesse cômputo, há conselhos de políticas, de direitos, de programas e conselhos administrativos. Foram criados os conselhos das cidades, da juventude, da economia solidária, do programa Primeiro Emprego, gestor da internet, de desenvolvimento industrial, de desenvolvimento econômico e industrial, do esporte, e de transparência e combate à corrupção. Reformularam-se os conselhos de recursos hídricos, da Embrapa, do desenvolvimento rural sustentável, da promoção da igualdade racial, da mulher, do combate à discriminação, dos direitos da pessoa portadora de deficiência, e de turismo. Ver, adicionalmente, o site da Secretaria Geral da Presidência (<www.secretariageral.gov.br/art_social/ conselhos-e-conferencias >), que computa entre 2003 e 2010 a criação de 19 conselhos e a reforma de 16 .
} 
Para além da expansão quantitativa de conselhos no ambiente dos municípios brasileiros, ressalta-se também sua diversidade, incluindo-se a criação de conselhos de direitos. Como ilustração, em 2009, os conselhos de direitos humanos foram constatados em 1,4\% do total de municípios; em 2011, os conselhos de direitos da mulher, em 10,7\%; de direitos do idoso, em 51,1\%; de direitos das pessoas com deficiência, em 14,2\%; e de promoção de igualdade racial, em 3,5\% do total (IBGE, 2009, 2011).

O panorama da existência dos conselhos em sua heterogeneidade e diversidade indica um alargamento de temas e objetos das políticas públicas e da participação social. No período posterior à promulgação da CF 1988 e dos novos marcos da legislação, o desafio inicial consistia na criação dessas instituições participativas e de sua consolidação. Atualmente, o desafio para os governos e a sociedade encontra-se em seu aprofundamento democrático, no aprimoramento dessas experiências e em sua maior efetividade, implicando o fortalecimento das capacidades de gestão e governança do Estado bem como dos atores societários.

As conferências nacionais - mecanismo de formulação e orientação de políticas públicas criadas, inicialmente, na década de 1930 - redesenharam-se com o impulso do processo de redemocratização e dos novos marcos legais, sobretudo mediante a incorporação expressiva da sociedade civil. A partir desse contexto, observam-se experiências isoladas no âmbito municipal e, de forma mais evidente, a expansão das conferências nacionais, seja no número de edições, seja no alargamento dos temas que as conformam, indicando uma maior inclusividade política.

Pogrebinschi e Santos (2011) demonstram que as conferências se tornam cada vez mais inclusivas pela sua amplitude e abrangência, em consequência da ampliação dos temas envolvidos, abrangendo crescentemente direitos das minorias e dos segmentos sociais mobilizados. No que toca ao primeiro ponto, os autores indicam que ocorreu uma ampliação de temas e edições de conferências: entre 1998 e 2009, foram realizadas 88 conferências, das quais 55 no período de 2003-2009. ${ }^{37}$ No que se refere ao segundo ponto, incluíram-se temas ligados às minorias, somando um total de 32 , dos quais 22 foram introduzidos no governo Lula.

Em relação ao segundo ponto, as conferências têm envolvido um conjunto cada vez mais heterogêneo de participantes que representam diversos grupos sociais, distribuídos entre organizações não governamentais, movimentos sociais, sindicatos de trabalhadores, entidades empresariais, entre outros (Pogrebinschi \& Santos, 2011; Pogrebinschi, 2012). Na maior parte dos casos, as conferências, nas diversas áreas de políticas e temas, têm incluído todos os estados e um número expressivo de municípios. Conforme indicações da Secretaria Nacional de Articulação Social, no período 20032012, elas mobilizaram, em seu conjunto, mais de 7 milhões de participantes (Brasil, 2014c). Tais tendências sinalizam a consolidação desse desenho participativo, que se mostra inclusivo e que aporta contribuições para o processo de formação de agenda das políticas em foco, ao lado da definição de diretrizes e de um acompanhamento participativo de sua gestão, favorecendo formas de articulação intergovernamental.

\footnotetext{
${ }^{37}$ Ver também, no site da Secretaria Geral da Presidência, o cômputo geral das conferências nacionais (<https:// novoportal.secretariageral.gov.br/participacao-social/conferencias $>$ ), que indica 127 conferências realizadas entre 1941 e 2013, sendo 86 entre 2003 e 2012.
} 
Na discussão empreendida, partiu-se do argumento de que a perspectiva de governança e, em especial, a de governança democrática ou participativa apresenta-se no Brasil de forma distinta dos países centrais, nos quais reemerge como sucedânea das concepções e ideários reformistas na linha da NPM ou como resposta aos déficits democráticos e de coordenação do rol de atores cada vez mais amplo e plural que integra o universo da gestão pública. No caso brasileiro, as propostas, projetos e práticas na trilha da governança participativa emergem em paralelo à disseminação dos ideários reformistas na vertente da NPM e das experiências concretas no âmbito federal e em alguns estados.

De fato, como se indicou, a trilha de governança com viés participacionista - por meio da criação e funcionamento de instituições participativas - resultou em um conjunto heterogêneo, abrangente, de práticas de participação institucionalizada, com desenhos, potenciais e alcances distintos. A tendência de expansão e pluralização dessas experiências, construídas ao longo das últimas décadas, aponta para a consolidação das instituições participativas. Aponta, também, para os desafios de seu aprimoramento em relação aos desenhos, funcionamento e efetividade; para desafios para a própria gestão pública a partir dos processos participativos; e para desafios da participação para os atores governamentais e não governamentais.

\section{Os Desafios da Modernização e Profissionalização da Administração Pública}

A profissionalização da administração pública brasileira tem conhecido importantes avanços desde meados dos anos 1990, que se aprofundam a partir da década passada. Esses avanços podem ser percebidos no crescimento sustentado da representatividade do vínculo estatutário - o que melhor se aproxima do modelo burocrático weberiano, dada a prevalência do recrutamento por concurso na estrutura do emprego público, conforme mostram os dados da Tabela 1.

Tabela 1 - Vínculos celetistas e estatutários na composição do emprego do setor público brasileiro,* em anos selecionados (pessoas)

\begin{tabular}{|l|c|c|c|c|}
\hline \multicolumn{1}{|c|}{ Tipo de vínculo } & 1995 & 2002 & 2009 & 2009/1995 (\%) \\
\hline Celetista permanente & 1.235 .450 & 873.583 & 635.997 & $-48,5$ \\
\hline Estatutário & 4.516 .170 & 4.427 .177 & 6.961 .433 & 57,2 \\
\hline Total & 5.751 .620 & 5.300 .760 & 7.597 .430 & 32,1 \\
\hline
\end{tabular}

*Estão excluídas empresas estatais e entidades públicas autônomas.

Fonte: adaptado de Nogueira \& Cardoso Jr., 2011: 418.

Como se nota, o número de empregados do setor público, considerando celetistas e estatutários cresce em 32,1\% entre os anos de 1995 e 2009. Esse aumento decorre basicamente da expansão do número de estatutários, já que os celetistas apresentam variação negativa no período. Assim, a representatividade dos estatutários nos empregos públicos permanentes - o que exclui as categorias 
de trabalhadores temporários e somente comissionados, além de estagiários - eleva-se de 78,5\% do total, em 1995, para 91,6\% em 2009.

Ao lado da crescente representatividade do emprego estatutário, contudo, observa-se um expressivo quantitativo de trabalhadores, designados por Marconi (2010) como "não estatutário sem carteira assinada", que alcança $21 \%$ do total de empregos na administração pública em 2007, considerando as três esferas de governo. Esse tipo de trabalhador com vínculo empregatício precário deveria desempenhar atividades temporárias, de natureza sazonal ou transitória. No entanto, não é o que ocorre na prática. Conforme pondera Marconi (2010: 233), "ao menos uma parcela dos servidores contratados sob essa forma precária possui um número de anos de serviço elevado", desempenhando atividades de natureza continuada.

Outra variável que indica o maior grau de profissionalização consiste no crescente nível de escolarização dos trabalhadores com vínculo permanente com a administração pública, conforme dados da Tabela 2. Há uma evolução bastante favorável na representatividade dos trabalhadores com nível de escolarização maior que ensino médio, que passa de 27,0\% do total em 1995 para 40,6\% em 2009. A melhoria da escolarização ocorre nos três níveis de governo, com um ganho mais expressivo nos municípios, onde o indicador passa de 15,6\% do total em 1995 para 33,\% em 2009. Ainda assim, são os governos locais aqueles que apresentam a situação mais desfavorável nesse quesito.

Tabela 2 - Participação de trabalhadores com grau de escolaridade maior que ensino médio no setor público brasileiro, * por nível de governo, em anos selecionados (\%)

\begin{tabular}{|l|c|c|c|}
\hline \multicolumn{1}{|c|}{ Esfera de governo } & 1995 & 2002 & 2009 \\
\hline Federal & 46,1 & 38,9 & 49,2 \\
\hline Estadual & 29,7 & 39,7 & 48,3 \\
\hline Municipal & 15,6 & 21,6 & 33,6 \\
\hline Total & 27,0 & 31,1 & 40,6 \\
\hline
\end{tabular}

* Estão excluídas empresas estatais e entidades públicas autônomas.

Fonte: Nogueira \& Cardoso Jr., 2011: 427.

Se os avanços na direção da profissionalização são inegáveis, também o são os desafios que se colocam na trajetória rumo à sua efetiva consolidação. A esse respeito, podem ser relacionados três fatores que atuam para dificultar esforços em busca da materialização desse desiderato político: o custo da construção de burocracias profissionalizadas, no sentido weberiano; o uso indiscriminado de cargos comissionados, de recrutamento amplo; e a herança de arranjos administrativos pretéritos, determinando a coexistência de relações de trabalho e situações de vínculo muito heterogêneas num mesmo órgão ou entidade. São fatores cujos efeitos incidem de forma desigual sobre os diferentes níveis de governo, afetando com maior intensidade os governos subnacionais.

No caso brasileiro, a capacidade de recrutar e reter pessoal, cujo balizamento mais geral é informado pelo orçamento, foi restringida pela citada LRF, que estabeleceu tetos para as despesas com pessoal para os diferentes níveis de governo. E as despesas de pessoal, nos governos subnacionais, já tensionam os limites 
impostos pela legislação, ${ }^{38}$ como mostram os dados da Tabela 3. No caso dos estados, em 2012, tais despesas chegaram a ultrapassar o teto. No caso dos municípios, havia ainda margem para o incremento da participação desse tipo de despesa, até porque o teto legal é superior ao estadual. Vale registrar que a terceirização de mão de obra, muitas vezes apontada como subterfúgio contábil para contornar as restrições da LRF, não pode efetivamente cumprir tal papel, ao ser bloqueada pela própria legislação. ${ }^{39}$

Tabela 3 - Participação das despesas com pessoal e limites da LRF, nos governos subnacionais, em 2012 (\%)

\begin{tabular}{|l|c|c|}
\hline \multicolumn{1}{|c|}{ Tipo de despesa } & Municípios & Estados \\
\hline Pessoal & 44,2 & 49,7 \\
\hline Limite da LRF & 54,0 & 49,0 \\
\hline
\end{tabular}

Fonte: adaptado de Khair, 2013.

Essa restrição imposta pela LRF assume contornos mais problemáticos quando se considera a necessidade de suprir os déficits de capacidade de atuação na prestação de serviços à população, em especial na área social, cuja responsabilidade vem sendo progressivamente assumida pelos níveis subnacionais de governo, como discutido anteriormente. Vale dizer, há uma pressão latente para ampliar quadros técnicos e administrativos e, por extensão, os gastos com pessoal, que praticamente não encontra espaço orçamentário para sua viabilização.

No tocante aos cargos comissionados, estes têm sido usualmente apontados pela literatura como um dos principais óbices à profissionalização da administração pública brasileira (Abrucio, 1993). Formalmente destinado a preenchimento das funções de direção e de assessoramento especializado, o cargo em comissão é de livre nomeação do governante. Esse aspecto - a livre nomeação - abre espaço para sua utilização de forma indiscriminada, notadamente na esfera local de governo, o que se insinua na expressividade de sua participação na estrutura do emprego público. De acordo com dados do IBGE (2012), os ocupantes de cargo em comissão - representados por funcionários sem vínculo permanente com o setor público, nomeados apenas para a função - correspondiam a 3,4\% do total de empregos públicos estaduais, em 2012, enquanto nos municípios alcançavam nada menos que $8,4 \%$ do correspondente total de empregos públicos.

A expressividade dos cargos em comissão indica sua utilização para funções que extravasam a alta direção e o assessoramento especializado, estendendo-se a cargos "que descem a níveis bastante baixos na estrutura" da administração pública (Pacheco, 2010: 287). Trata-se de nomeações de caráter político, que colidem com os supostos da burocracia weberiana em dois aspectos principais, ainda que não restritos aos mesmos. Um deles, mais evidente, tem a ver com a forma de recrutamento, que prescinde do concurso ou qualquer forma de avaliação competitiva de competências e habilidades

${ }^{38}$ Ainda que o limite imposto para despesas com pessoal do governo federal - da ordem de $40,9 \%$ da RCL - seja menor que os dos governos estaduais e municipais, os gastos com pessoal no Executivo federal, em 2012, ficaram em torno de $23 \%$ do total, ou seja, bem abaixo do permitido pela LRF.

${ }^{39} \mathrm{~A}$ LRF determina que os valores dos contratos com terceirização de mão de obra, que tenha correspondência com categorias funcionais abrangidas pelo plano de cargos do quadro de pessoal do órgão ou entidade, sejam contabilizados, para fins de enquadramento no limite legal, como despesa de pessoal. 
concernentes ao cargo a ser preenchido. O outro se refere à natureza transitória do desempenho da função, gerando descontinuidades administrativas e gerenciais, ao dificultar a preservação da memória institucional e cercear o aprendizado advindo da experiência.

Por fim, as decisões dos gestores públicos relativas à contratação de pessoal passam comumente ao largo da preocupação de estruturar um aparato administrativo de conformação burocrática, composto por corpos permanentes lastreados na ideia de carreira como princípio geral da organização da função pública. De um lado, há o reconhecimento, por parte da literatura, de que a administração pública brasileira "foi constituída a partir de cargos e não de carreiras" (Costa, 2011: 82), cuja estrutura, quando existente, nem sempre é definida de forma consistente (Nogueira \& Cardoso Jr., 2011). Como observa Loureiro (1998), a definição mais usual de carreira abrange um conjunto de cargos e funções hierarquicamente definidos, com a possibilidade de avanço vertical em torno de mais de um cargo. Tal concepção, contudo, revela-se mais exceção que regra no país, cujas carreiras tendem a ser formadas por "cargos isolados ou planos gerais que constituem meras agrupações de cargos" (Nogueira \& Cardoso Jr., 2011: 425). De outro lado, prevalecem o imediatismo e a adoção de soluções tópicas na gestão de recursos humanos, em detrimento de um planejamento institucional de longo prazo (Nogueira \& Cardoso Jr., 2011), o que se expressa na criação casuística de carreiras e cargos (Carvalho, 2011), da qual não escapa sequer o governo federal. Tem-se, em consequência, uma situação caracterizada pela existência de uma multiplicidade de "cargos e carreiras, sem um eixo norteador que os vincule entre si e estabeleça critérios hierárquicos mais consistentes" (Carvalho, 2011: 142). A título de ilustração, levantamento feito por Carvalho (2011: 141) registra a existência, em 2010, de nada menos " 129 carreiras e 22 planos especiais de cargos (...), além de cargos isolados" no âmbito do governo federal. A esse quadro se soma a adoção de expedientes variados, como a cessão de pessoal entre órgãos e mesmo governos e a contratação irregular de trabalhadores temporários, entre outros, tornando ainda mais complexo o gerenciamento de pessoal.

Análise realizada por Costa (2011), relativa ao Ministério da Saúde (MS), ilustra bem a questão. Somente em 2005, após mais de duas décadas, houve a retomada da realização de concursos no MS, o que é atribuído, pela autora, à pressão do Ministério Público do Trabalho (MPT), em face de irregularidades na contratação de trabalhadores, mais especificamente, a expressiva parcela de funções ocupadas por terceirizados e detentores de contratos temporários de trabalho. ${ }^{40} \mathrm{Na}$ sede do MS, responsável pela formulação e gestão da política setorial, apenas 31\% do quadro de pessoal era, à época, formado por servidores efetivos, recrutados por meio de concurso; participação que se eleva para $57 \%$ do total em 2011. Os servidores efetivos do MS, por sua vez, distribuíam-se em diversos planos de carreiras e em planos especiais de cargos, incluindo o Plano Geral de Cargos do Poder Executivo (PGPE) ${ }^{41}$ e o Plano de Classificação de Cargos (PCC). ${ }^{42}$

\footnotetext{
${ }^{40}$ Nesse ano, os profissionais terceirizados, com contratos temporários com a União e consultores contratados com a intermediação de organismos internacionais no MS somavam 9.762 pessoas (Costa, 2011).

${ }^{41}$ Criado pela lei n. 11.357/2006, o PGPE é composto por cargos efetivos de nível superior, médio e auxiliar que não integram carreiras específicas, planos especiais de cargos ou planos de carreiras instituídos por leis específicas.

${ }^{42}$ O PCC foi estabelecido pela lei n. 5.645/1970, com o propósito de enquadrar a totalidade do pessoal civil (Carvalho: 2011), agrupando os servidores públicos em classes, que posteriormente adquiriram características de carreira. Segundo Costa (2011), o PCC absorvia, em 2005, cerca de 65 mil servidores do MS.
} 
O movimento na direção da profissionalização da administração pública, cuja face mais visível é a crescente institucionalização da realização de concursos como forma de recrutamento de servidores nos diferentes níveis de governo, aparenta ser um caminho de difícil reversão na realidade brasileira. Essa mesma adesão à realização de concursos serve também para lançar luz sobre os limites do processo, notadamente na esfera local de governo. De fato, os concursos que vêm ocorrendo nos municípios não refletem necessariamente uma decisão autônoma do gestor local, decorrendo, em diversas circunstâncias, de ações administrativas ou judiciais movidas por organismos de fiscalização e controle externo, como o MPT e os Tribunais de Contas. Além disso, os processos de seleção utilizados nem sempre são abertos e universais, assumindo apenas caráter interno, por meio dos quais se busca efetivar funcionários sem vínculos permanentes da administração municipal. A persistência do recurso à contratação irregular atestada pela expressividade dos trabalhadores sem vínculo permanente ${ }^{43} \mathrm{com}$ a administração pública, da ordem de $27,6 \%$ do total do emprego municipal em 2012 - refletindo "o imediatismo e o casuísmo da mentalidade do gestor público" (Nogueira \& Cardoso Jr., 2011: 437) no tocante à contratação de pessoal, mostra as dificuldades com as quais o concurso ainda se defronta.

A despeito da inegável relevância desse tipo de restrição, a fragilidade financeira da administração pública, em especial nas esferas dos governos estadual e municipal, emerge como a principal dificuldade que se interpõe à profissionalização, na medida que assume caráter estrutural. De fato, não se vislumbram perspectivas favoráveis de ampliações significativas da capacidade de financiamento do setor público descoladas do crescimento da economia, até porque a carga tributária já alcançou patamar elevado, situando-se próximo à média dos países da OCDE (Khair, 2013), que apresentam, regra geral, renda per capita superior à brasileira. Trata-se de uma restrição que assume contornos mais críticos em face da baixa qualidade da oferta de serviços públicos, em especial nas áreas que respondem às necessidades mais imediatas da população - saúde, educação, segurança pública, proteção social etc. - a qual não tem como ser enfrentada apenas com melhorias na qualificação dos servidores, demandando também ampliação da capacidade de oferta e, por extensão, do quadro de servidores.

As principais perspectivas de avanços na profissionalização da administração pública brasileira recaem na esfera federal que, historicamente, detém as condições institucionais e financeiras mais confluentes com a construção de uma burocracia consoante as premissas weberianas. Esse processo deve abarcar um conjunto ampliado de funções no âmbito das atividades do núcleo estratégico ou exclusivas do Estado. O que se tem em mente aqui é a assunção de novas atribuições relacionadas às atividades de formulação e gestão de políticas públicas e de regulação econômica e social, demandando profissionais com qualificação técnica para lidar com as mesmas, como, por exemplo, profissionais com formação na área de engenharia. Nos níveis subnacionais de governo, em especial no nível local, a pressão pela expansão e melhoria na prestação de serviços públicos tende a levar ao crescimento do número de servidores, criando dificuldades financeiras no tocante ao recrutamento de profissionais mais qualificados ou à realização de investimentos na qualificação dos servidores já contratados. Assim, avanços no sentido da profissionalização devem assumir caráter mais circunscrito que no governo federal, com uma maior seletividade na definição do que se considera estratégico para fins de construção de capacidade burocrática informada pelas premissas do modelo weberiano.

\footnotetext{
${ }^{43}$ Inclui trabalhadores temporários e somente comissionados, além de uma pequena parcela de estagiários.
} 


\section{Considerações Finais}

A administração pública brasileira vem passando por transformações de grande magnitude desde a última década do século XX e que se aprofundam no decorrer do século XXI. São transformações que envolvem tanto as funções que o setor público desempenha quanto a forma como este se organiza para desempenhá-las, ou seja, suas dimensões funcional e organizacional. Ainda que o processo de mudanças guarde similaridades com iniciativas reformistas desenvolvidas no plano internacional, ele apresenta traços que são peculiares ao país, seja no tocante às motivações para as inovações introduzidas, seja no tocante à sua implementação e aos resultados alcançados.

No que se refere às mudanças ocorridas nas funções desempenhadas pelo Estado brasileiro, embora a análise empreendida não tenha se dedicado explicitamente à sua discussão, restaram evidenciadas três questões principais. A primeira diz respeito ao alargamento da prestação de serviços na área social, impulsionado, em larga medida, pela definição de direitos sociais, de recorte universalizado, no âmbito da CF 1988, cuja observância vem sendo crescentemente incorporada à agenda pública. A segunda está relacionada à inflexão, iniciada no primeiro governo Lula, na agenda política neoliberal prevalecente até o segundo governo Fernando Henrique Cardoso, trazendo de volta a percepção de que o Estado tem um papel importante na promoção do desenvolvimento econômico e social, que não pode ser simplesmente delegada ao mercado. A terceira remete ao rol ampliado de funções de natureza regulatória, advindas tanto da retroação do intervencionismo estatal na economia, refletindo as iniciativas de privatização, em especial na área de infraestrutura econômica, quanto das transformações estruturais da própria economia e da sociedade como um todo, intensificadas pela acelerada incorporação de novas tecnologias e pelo fenômeno da globalização.

Já no tocante às transformações na estrutura organizacional do setor público e seus mecanismos de atuação, a análise colocou em relevo três processos principais. O primeiro aglutina-se em torno do movimento de delegação da execução de um conjunto diversificado de serviços públicos, inscritos no rol de atividades não exclusivas do Estado, a organizações da sociedade civil ou da iniciativa privada. Como visto, trata-se de um movimento cujo protagonismo recai nos governos subnacionais e que é movido por razões que avançam além da justificativa de obtenção de ganhos de eficiência, usualmente citada na literatura, como a preocupação em contornar a necessidade de expansão do aparato da administração pública e a busca de alternativas para lidar com restrições na capacidade de financiamento da realização de investimentos via orçamento. Dele resultam novos arranjos organizacionais, tipificados pelas OSs, Oscips e PPPs, que vêm se somar às modalidades de terceirização e parceria convencionalmente adotadas pela administração pública brasileira. O segundo remete à descentralização intergovernamental, com a crescente execução da prestação de serviços na área social pelos governos locais, conferindo materialidade a diretrizes descentralizantes do texto constitucional. O processo é comandado e induzido pelo governo federal, cabendo aos governos estaduais, grosso modo, uma atuação complementar e subsidiária à dos governos locais. Do processo advém um redesenho profundo da estrutura do emprego público no país, que se torna majoritariamente local. O terceiro e último processo condensa as iniciativas de aprofundamento democrático no desenvolvimento das atividades de governo, em sintonia, também aqui, com diretrizes do texto constitucional. 
São iniciativas confluentes com a ideia de governança democrática, da qual emerge uma pluralidade de instituições participativas, notadamente na esfera local de governo, que mediatizam o envolvimento da sociedade na implementação das políticas públicas, favorecendo sua capacidade de influir nas decisões relativas à definição da agenda pública e, principalmente, de monitorar e avaliar sua execução.

Desses processos reformistas emergem novos padrões de relações internas no Estado e entre ele, o mercado e a sociedade civil, conformando uma arquitetura organizacional de crescente complexidade. Isso demanda novas formas de coordenação, integração e controle das atividades do setor público, reafirmando a importância da construção de burocracias meritocráticas e dotadas de expertise pública como condição primária e indispensável para a ampliação da capacidade de atuação do Estado. Reside aqui o principal desafio com o qual se defronta a administração pública brasileira do período contemporâneo.

A profissionalização da administração pública começou a ser ensaiada no país, como visto, nos anos 1930. Manteve-se, contudo, como um processo em aberto, no sentido de parcial ou inconcluso, sendo reafirmada, como um desiderato político, e relançada pela CF 1988. A despeito dos inegáveis avanços que vêm sendo observados desde então, na direção da construção de uma burocracia profissionalizada, há, ainda, um longo e difícil caminho a percorrer. Uma das principais dificuldades que emergem nesse percurso diz respeito ao movimento de descentralização. De fato, o emprego público vem se concentrando nos níveis subnacionais de governo, com destaque para os governos locais, que apresentam, reconhecidamente, menor capacidade de recrutar e reter profissionais para as atividades mais exigentes de qualificação técnica e conhecimento especializado. Outra dificuldade refere-se à persistência de práticas de contratação de pessoal que passam ao largo de critérios de impessoalidade e meritocracia, da qual não escapa sequer o governo federal. Por fim, cabe mencionar o legado das políticas adotadas na área de recursos humanos nas diferentes esferas de governo, que implica formas muito variadas de classificação, remuneração e gratificação para os servidores públicos, de gerenciamento complexo, constituindo um obstáculo a mais para o aprimoramento e a modernização da gestão pública.

Por sua vez, o aprimoramento e a modernização da gestão pública brasileira não podem prescindir do protagonismo do governo federal, com iniciativas consistentes de apoio à construção de capacidade administrativa nos níveis subnacionais de governo. De certa forma, o Programa Nacional de Apoio à Modernização da Gestão e do Planejamento dos Estados e do Distrito Federal (Pnage) e o Programa de Modernização do Controle Externo dos Estados e Municípios (Promoex), ambos lançados pelo governo Lula, são iniciativas que denotam o reconhecimento da importância da cooperação, no plano federativo, para enfrentar déficits de aparelhamento burocrático na implementação de políticas e no atendimento às demandas e necessidades dos cidadãos. Sem entrar no mérito dos resultados de tais programas, até porque sequer discutidos, cabe observar que, sem a definição de uma agenda consistente em prol da reforma da gestão pública, com uma perspectiva de longo prazo, capaz de galvanizar o interesse e o compromisso dos diferentes níveis de governo em torno de sua execução, dificilmente o Brasil levará a termo a profissionalização de sua burocracia. Trata-se de empreendimento que nada tem de trivial, tendo em vista, em particular, as características muito heterogêneas do federalismo no país. 


\section{Referências}

ABRUCIO, F. L. Profissionalização do serviço público federal. In: ANDRADE, R. C. \& JACCOUD, D. (Orgs.). Estrutura e Organização do Poder Executivo. Brasília: Enap/SAF, 1993.

ABRUCIO, F. L. Para além da descentralização: os desafios da coordenação federativa no Brasil. In: FLEURY, S. (Org.). Democracia, Descentralização e Desenvolvimento: Brasil e Espanha. Rio de Janeiro: FGV, 2006.

ABRUCIO, F. L.; PEDROTI, P. \& PÓ, M. V. A formação da burocracia brasileira: a trajetória e o significado das reformas administrativas. In: LOUREIRO, M. R.; ABRÚCIO, F. L. \& PACHECO, R. S. (Orgs.). Burocracia e Política no Brasil: desafios para o Estado democrático no século XXI. Rio de Janeiro: FGV, 2010.

AFFONSO, R. \& SILVA, P. L. B. Descentralização e Políticas Sociais. São Paulo: Fundap, 1996.

ARRETCHE, M. Mitos da descentralização: mais democracia e eficiência nas políticas públicas. Revista Brasileira de Ciências Sociais, 11(31): 44-67, 1996.

ARRETCHE, M. Estado Federativo e Políticas Sociais: determinantes da descentralização. Rio de Janeiro, São Paulo: Revan, Fapesp, 2000.

ARRETCHE, M. Democracia, Federalismo e Centralização no Brasil. Rio de Janeiro: Editora FGV, Editora Fiocruz, 2012.

ARRETCHE, M. (Coord.). Capacidades Administrativas dos Municípios Brasileiros para a Política Habitacional. Brasília: Ministério das Cidades, Secretaria Nacional de Habitação, 2013.

BELSITO, B. G. \& VIANA, F. B. O limite de comprometimento da receita corrente líquida em contratos de parceria público-privada. Revista do BNDES, 39: 123-160, 2013.

BERAMENDI, P. Federalism. In: BOIX, C. \& STOKES, S. C. (Eds.). The Oxford Handbook of Comparative Politics. New York: Oxford University Press, 2009.

BLÖNDAL, J. R. International Experience Using Outsourcing, Public-Private Partnerships, and Vouchers. Washington: IBM Center for the Business of Government, 2005.

BOURGON, J. Finalidade pública, autoridade governamental e poder coletivo. Revista do Serviço Público, 61(1): 5-34, 2010.

BRASIL. Ministério da Administração e Reforma do Estado. Plano Diretor da Reforma do Aparelho do Estado. Brasília: Mare, 1995.

BRASIL. Senado Federal. Constituição da República Federativa do Brasil. Brasília: Saraiva, 2006.

BRASIL. Ministério do Planejamento, Orçamento e Gestão. Secretaria de Gestão. Relações de Parceria entre Poder Público e Entes de Cooperação e Colaboração no Brasil. Brasília: MPOG, Seges, 2010.

BRASIL. Constituição dos Estados Unidos do Brasil [1946]. Disponível em: http://presrepublica.jusbrasil.com. br/legislacao/92058/constituicao-d. Acesso: 6 mar. 2014a.

BRASIL. Controladoria-Geral da União. Secretaria Federal de Controle Interno. Termos de Parceria firmados pelo Ministério da Justiça com Oscips entre os exercícios de 2008 a 2011. Relatório de Auditoria Especial n. 00190.009683/2011-31. Disponível em: <http://sistemas2.cgu.gov.br/relats/uploads/5728_\%20Termos\%20 de\%20Parceria\%20-\%20MJ.pdf>. Acesso em: 13 mar. 2014b.

BRASIL. Secretaria Geral da Presidência. Participação Social no Brasil: entre conquistas e desafios. Brasília: Secretaria Geral da Presidência da República, 2014c. Disponível em: <https://novoportal.secretariageral.gov. br/participacao-social>. Acesso em: 8 de ago. 2014.

BRASIL, F. P. D. \& CARNEIRO, R. Os caminhos (e descaminhos) de democratização das políticas urbanas: o que há de novo no Brasil contemporâneo? Cadernos Gestão Pública e Cidadania, 55: 11-42, 2010. 
BRESSER-PEREIRA, L. C. Da administração pública burocrática à gerencial. Revista do Serviço Público, 47(1):128, 1996.

BRITO, B. M. B. \& SILVEIRA, A. H. P. Parceria público-privada: compreendendo o modelo brasileiro. Revista do Serviço Público, 56(1): 7-21, 2005.

CARNEIRO, R. \& MENICUCCI, T. M. G. Gestão Pública no século XXI: as reformas pendentes. Brasília, IPEA, 2011. (Texto para Discussão n. 1.686).

CARVALHO, E. D. C. Emprego público e ocupações no serviço público municipal nos anos 2000. In: CARDOSO JR., J. C. (Org.). Burocracia e Ocupação no Setor Público Brasileiro. Rio de Janeiro, Ipea, 2011.

CHRISTENSEN, T. \& LAEGREID, P. The whole-of-government approach to public sector reform. Public Administration Review, 67(6): 1.059-1.066, 2007.

CHRISTENSEN, T. \& LAEGREID, P. Governance and administrative reforms. In: LEVI-FAUR, D. (Ed.). The Oxford Handbook of Governance. Oxford: Oxford University Press, 2012.

COMISSÃO DAS COMUNIDADES EUROPEIAS. Livro Verde sobre as Parcerias Público-Privadas e o Direito Comunitário em Matéria de Contratos Públicos e Concessões. Bruxelas: CCE, 2004.

CORTES, S. M. V. Fóruns participativos e governança: uma sistematização das contribuições da literatura. In: LUBAMBO, C.; COELHO, D. B. \& MELO, M. A. (Orgs.). Desenho Institucional e Participação Política: experiência no Brasil contemporâneo. Petrópolis: Vozes, 2005.

COSTA, L. A. Insulamento Burocrático, Autonomia do Estado e Inserção Social: um estudo do Ministério da Saúde na coordenação nacional do SUS, 2011. Tese de Doutorado, Belo Horizonte: Faculdade de Sociologia e Ciências Humanas, Universidade Federal de Minas Gerais.

DI PIETRO, M. S. Z. Parcerias na Administração Pública: concessão, permissão, franquia, terceirização e outras formas. São Paulo: Atlas, 1997.

DUNLEAVY, P. \& HOOD, C. From old public administration to new public management. Public Money and Management, 14(3): 9-16, 1994.

DUNLEAVY, P. et al. New Public Management is dead: long live digital-era governance. Journal of Public Administration Research and Theory, 16: 467-493, 2005.

FISHER, F. Participatory governance: from theory to practice. In: LEVI-FAUR, D. (Ed.). The Oxford Handbook of Governance. Oxford: Oxford University Press, 2012.

FUNG, A. Associations and democracy: between theories, hopes and realities. Annual Review of Sociology, 29: 515-539, 2003.

FUNG, A. \& WRIGHT, E. O. Deepening democracy: institutional innovations in empowered participatory governance. Politics and Science, 29(1): 5-41, 2001.

GOHN, M. G. Os conselhos municipais e a gestão urbana. In: SANTOS JÚNIOR, O.; RIBEIRO, L. C. \& AZEVEDO, S. (Orgs.). Governança Democrática e Poder Local. Rio de Janeiro: Revan, 2004.

HOOD, C. A public management for all seasons? Public Administration, 69(1): 3-19, 1991.

HOOD, C. The New Public Management in the 1980s: variations on a theme. Accounting, Organizations and Society, 20(2/3): 93-109, 1995.

HOOD, C. \& PETERS, G. The middle aging of New Public Management: into the Age of Paradox. Journal of Public Administration Research and Theory, 14(3): 267-282, 2004.

INSTITUTO BRASILEIRO DE GEOGRAFIA E ESTATÍSTICA (IBGE). Perfil dos Municípios Brasileiros 2001. Rio de Janeiro: IBGE, 2001. 
INSTITUTO BRASILEIRO DE GEOGRAFIA E ESTATÍSTICA (IBGE). Perfil dos Municípios Brasileiros 2008. Rio de Janeiro: IBGE, 2008.

INSTITUTO BRASILEIRO DE GEOGRAFIA E ESTATÍSTICA (IBGE). Perfil dos Municípios Brasileiros 2009. Rio de Janeiro: IBGE, 2009.

INSTITUTO BRASILEIRO DE GEOGRAFIA E ESTATÍSTICA (IBGE). Perfil dos Municípios Brasileiros 2011. Rio de Janeiro: IBGE, 2011.

INSTITUTO BRASILEIRO DE GEOGRAFIA E ESTATÍSTICA (IBGE). Perfil dos Municípios Brasileiros 2012. Rio de Janeiro: IBGE, 2012.

INSTITUTO BRASILEIRO DE GEOGRAFIA E ESTATÍSTICA (IBGE). Perfil de Informações Básicas Estaduais 2012. Rio de Janeiro: IBGE, 2013.

KETTL, D. F. A revolução global: reforma da administração do setor público. In: BRESSER-PEREIRA, L. C. \& SPINK, P. (Orgs.). Reforma do Estado e Administração Pública Gerencial. Rio de Janeiro: Editora FGV, 2005.

KHAIR, A. A Questão Fiscal e o Papel do Estado. São Paulo: Fundação Perseu Abramo, 2013.

KLINJ, E. H. New public management and governance. In: LEVI-FAUR, D. (Ed.). The Oxford Handbook of Governance. Oxford: Oxford University Press, 2012.

LEVI-FAUR, D. From government to big governance. In: LEVI-FAUR, D. (Ed.). The Oxford Handbook of Governance. Oxford: Oxford University Press, 2012.

LIMA JR., O. B. As reformas administrativas no Brasil: modelos, sucessos e fracassos. Revista do Serviço Público, 2, ano 49: 5-30,1998.

LOPEZ, F. G. \& BARONE, L. As Entidades sem Fins Lucrativos e as Políticas Públicas Federais: tipologia e análise de convênios e organizações (2003-2011). Brasília: Ipea, 2013. (Texto para Discussão n. 1.896)

LOPEZ, F. G. \& BUENO, N. S. Transferências Federais a Entidades Privadas sem Fins Lucrativos (1999-2010). Rio de Janeiro: Ipea, 2012. (Texto para Discussão 1.778)

LOUREIRO, M. R. Radiografia da alta burocracia federal brasileira: o caso do Ministério da Fazenda. Revista do Serviço Público, 4, ano 49: 47-83, 1998.

LYNN JR., L. E. Public management: a concise history of the field. In: LYNN JR., L. E. \& POLLITT, C. (Eds.). The Oxford Handbook of Public Management. Oxford: Oxford University Press, 2007.

LYNN JR., L. E. The many faces of governance: adaptation? Transformation? Both? Neither? In: LEVI-FAUR, D. (Ed.). The Oxford Handbook of Governance. Oxford: Oxford University Press, 2012.

MANNING, N. et al. Reformas de Gestão Pública: o que a América Latina tem a aprender com a OCDE? In: MEDEIROS, P. C. \& LEVY, E. (Orgs.). Novos Caminhos da Gestão Pública: olhares e dilemas. Rio de Janeiro, Brasília: Qualitymark, Consad, 2009.

MARCH, J. G. \& OLSEN, J. P. Rediscovering Institutions: the organizational basis of politics. New York: Free Press, 1989.

MARCONI, N. Uma radiografia do emprego público no Brasil: análise e sugestões de políticas. In: LOUREIRO, M. R.; ABRÚCIO, F. L. \& PACHECO, R. S. (Orgs.). Burocracia e Política no Brasil: desafios para o Estado democrático no século XXI. Rio de Janeiro: FGV, 2010.

MORONI, J. A. O direito à participação no governo Lula. In: AVRITZER, L. (Org.). Experiências Nacionais de Participação Social. São Paulo: Cortez, 2009.

NOGUEIRA, R. P. \& CARDOSO JR., J. C. Tendências e problemas da ocupação do setor público brasileiro: conclusões parciais e recomendações de pesquisa. In: CARDOSO JR., J. C. (Org.). Burocracia e Ocupação no Setor Público Brasileiro. Rio de Janeiro: Ipea, 2011. 
NUNES, E. A Gramática Política no Brasil: clientelismo e insulamento burocrático. Rio de Janeiro, Brasília: Jorge Zahar, Enap, 1997.

PPP BRASIL: O OBSERVATÓRIO DAS PARCERIAS PÚBICO-PRIVADAS. Procedimento de manifestação de interesse nos Estados: relatório sobre projetos de PPP em fase de estruturação via PMI, 2012. Disponível em: $<$ http://pppbrasil.com.br/portal/content/ppp-brasil-divulga-relatorio-sobre-os-pmis-nos-estados-0 >. Acesso em: 25 fev. 2014.

OLIVEIRA, F. A. Fundef e Saúde: duas experiências (virtuosas?) de descentralização. In: REZENDE, F. \& OLIVEIRA, F. A. (Orgs.). Descentralização e Federalismo Fiscal no Brasil: desafios da reforma tributária. Rio de Janeiro: Konrad Adenauer Stiftung, 2003.

OLIVEIRA, F. A. Política Econômica, Estagnação e Crise Mundial: Brasil, 1980-2010. Rio de Janeiro: Beco do Azougue, 2012.

PACHECO, R. S. A agenda da nova gestão pública. In: LOUREIRO, M. R.; ABRÚCIO, F. L. \& PACHECO, R. S. (Orgs.). Burocracia e Política no Brasil: desafios para o Estado democrático no século XXI. Rio de Janeiro: FGV, 2010.

PEREIRA, L. D. A gestão da força de trabalho em saúde na década de 90. Physis - Revista de Saúde Coletiva, 14(2): 363-382, 2004.

PESSOA, E. Estado, serviços públicos e emprego público no Brasil: principais tendências nos anos 90. In: ENCONTRO NACIONAL DE ECONOMIA POLÍTICA, VIII, 2003, Florianópolis.

PETERS, B. Guy. Governance as political theory. In: LEVI-FAUR, D. (Ed.). The Oxford Handbook of Governance. Oxford: Oxford University Press, 2012.

PIERRE, J. New Governance, New Democracy? Gothenburg: University of Gothenburg, mar. 2009. (QOG Working Paper Series 4)

PIRES, D. Reestruturação Produtiva e Trabalho em Saúde no Brasil. São Paulo: Annablume, 2008.

POLLITT, C. Decentralization. In: FERLIE, E.; LYNN JR., L. E. \& POLLITT, C. (Eds.). The Oxford Handbook of Public Management. Oxford: The Oxford University Press, 2007.

POLLITT, C. \& BOUCKAERT, G. Avaliando reformas da gestão pública: uma perspectiva internacional. Revista do Serviço Público, 53(3): 5-30, 2002.

POLLITT, C. \& BOUCKAERT, G. Public Management Reform: a comparative analysis. New York: Oxford University Press, 2004.

POGREBINSCHI, T. Conferências Nacionais de Políticas Públicas para Grupos Minoritários. Rio de Janeiro: Ipea, 2012. (Texto para discussão n.1.741)

POGREBINSCHI, T. \& SANTOS, F. Participação como representação: o impacto das conferências nacionais de políticas públicas no Congresso. Dados - Revista de Ciências Sociais, 54(3): 259-305, 2011.

PRZEWORSKI, A. O Estado e o cidadão. In: BRESSER-PEREIRA, L. C.; WILHEIN, J. \& SOLA, L. (Orgs.). Sociedade e Estado em Transformação. São Paulo: Editora Unesp, 1999.

RAICHELIS, R. Intervenção profissional do assistente social e as condições de trabalho no Suas. Serviço Social \& Sociedade, 104: 750-772, 2010.

REZENDE, F. C. As reformas e as transformações no papel do Estado: o Brasil em perspectiva comparada. In: ABRUCIO, F. L. \& LOUREIRO, M. R. (Orgs.). O Estado numa Era de Reformas: os anos FHC - Parte 1. Brasília: MP, Seges, 2002.

SKELCHER, C. Public-Private Partnerships and hybridity. In: FERLIE, E.; LYNN JR., L. E. \& POLLITT, C. (Eds.). The Oxford Handbook of Public Management. Oxford: The Oxford University Press, 2007. 
SMITH, S. R. NGOs and contracting. In: FERLIE, E.; LYNN JR., L. E. \& POLLITT, C. (Eds.). The Oxford Handbook of Public Management. Oxford: The Oxford University Press, 2007.

SOUZA, C. Federalismo, desenho constitucional e instituições federativas no Brasil pós-1988. Revista Sociologia Política, 24: 105-121, 2005.

STOKER, G. Governance as theory: five propositions. International Social Science Journal, 50(1.555): 17-28, 1998.

TATAGIBA, L. Conselhos gestores e a burocratização das políticas públicas no Brasil. In: DAGNINO, E. (Org.). Sociedade Civil e Participação Social no Poder Local. Rio de Janeiro: Paz e Terra, 2002.

TORRES, M. D. F. Agências, Contratos e Oscips: a experiência brasileira. Rio de Janeiro: FGV, 2007.

TOURINHO, R. A atuação do Ministério Público do Trabalho no combate a terceirização do sistema carcerário no Brasil. Revista Eletrônica de Direito Administrativo Econômico (Redae), 13: 1-10, 2008.

TRIBUNAL DE CONTAS DA UNIÃO (TCU). Acórdão 3.025/2010: plenário. Relatório de levantamento. Fiscalis 814/2010. Avaliação da estrutura de recursos humanos voltada para a análise da prestação de contas de transferências voluntárias da União. Disponível em: <www.lexml.gov.br/urn/urn:lex:br:tribunal.contas.uniao ;plenario:acordao:2010-11-10;3025 > . Acesso em: 12 fev. 2014a.

TRIBUNAL DE CONTAS DA UNIÃO (TCU). Relatório de Auditoria Operacional: TC 018.739/2012-1. Transferência do gerenciamento de serviços públicos de saúde a organizações sociais. Falhas. Determinações e recomendações. Monitoramento. Disponível em: <www.jusbrasil.com.br/diarios/62587424/dou-secao-1-05-12-2013-pg-326>. Acesso em: 4 mar. 2014b.

VINCENT, A. Theories of State. Cambridge: Blackwell Publishers, 1987.

WAMPLER, B. Instituições participativas como enxertos na estrutura do Estado: a importância de contextos, atores e estratégias. In: PIRES, R. R. C. (Org.). Efetividade das Instituições Participativas no Brasil. Brasilia: Ipea, 2011.

WILLIANSON, O. E. Transaction-cost economics: the governance of contractual relations. Journal of Law and Economics, 22(2): 233-261, 1979. 



\title{
QUAL PADRÃO DE DESENVOLVIMENTO? CENÁRIOS MACROECONÔMICOS A LONGO PRAZO'
}

\author{
Salvador Werneck Vianna \\ Maria Lucia Werneck Vianna ${ }^{2}$
}

De acordo com dados da Secretaria de Ciência, Tecnologia e Insumos Estratégicos do Ministério da Saúde, a cadeia produtiva da saúde movimenta um volume de recursos superior a $6 \%$ do Produto Interno Bruto (PIB), emprega diretamente, com trabalhos qualificados formais, parcela expressiva da força de trabalho brasileira e é a área de maior expressão no país em investimentos públicos com pesquisa e desenvolvimento (MS \& Opas, 2015). Em termos de empregos diretos e indiretos, em toda a cadeia produtiva, o conjunto dessas atividades representa cerca de 7,5 milhões de trabalhadores inseridos, predominantemente, em atividades intensivas em conhecimento (MS, 2007). ${ }^{3}$

A saúde, portanto, pode ser considerada em uma dupla perspectiva: numa dimensão, vem a se constituir vetor absolutamente central do sistema de proteção social brasileiro; noutra, permeia toda a cadeia produtiva. Não só as condições macro e microeconômicas da sociedade influenciam a configuração do setor Saúde, como também as vicissitudes deste têm impacto sobre apolítica macroeconômica e sobre o comportamento dos agentes.

É uma relação mútua. Quanto mais se avançar na qualificação e consolidação de instrumentos de política que aprimorem a governança macroeconômica, ${ }^{4}$ maior será a capacidade do Estado

\footnotetext{
${ }^{1}$ Este capítulo foi resultado de um estudo encomendado pela Fundação Oswaldo Cruz (Fiocruz) no âmbito da iniciativa Brasil Saúde Amanhã, cuja conclusão se deu no primeiro semestre de 2014.

Ao ser publicado somente agora, segundo semestre de 2016, apresenta-se o óbvio (e gigante) problema da não inclusão dos anos de 2014 e 2015. Nesse período, como notório, houve uma combinação cataclísmica de crises econômica e política, com resultados dramáticos que incluem uma recessão profunda e prolongada e a deposição de Dilma Roussef da Presidência da República, cujos desdobramentos ainda estão em pleno curso ao escrevemos esta nota (maio de 2016). A análise aqui desenvolvida refere-se ao período de 2003 a 2013 e, portanto, não abarca esse período recente. Cabe destacar que, se isso implica, por um lado, a necessidade de um cuidado ainda maior na avaliação e análise dos cenários de longo prazo construídos na seção final do capítulo, por outro, confirma e corrobora integralmente os argumentos apresentados logo antes da descrição dos cenários, quando ressaltamos a incerteza, em sentido keynesiano, que permeia de modo inexorável o funcionamento dos sistemas econômicos. E que torna, por conseguinte, particularmente difícil, para dizer o mínimo, todo e qualquer exercício de previsão.

2 Agradecemos a Caroline Teixeira Jorge e Camila Ferraz pelo excelente trabalho de assistência de pesquisa.

${ }^{3} \mathrm{O}$ documento da referida secretaria não explicita a fonte dessa informação. As Contas Nacionais do IBGE reportam um total de ocupações nos setores saúde pública, saúde mercantil e farmacêutico que não ultrapassa 3,5 milhões em 2009, último dado disponível. Possíveis exageros à parte, trata-se sem dúvida de uma ordem de grandeza bastante expressiva.

${ }^{4}$ Aqui entendida como o conjunto de ações na gestão do juro, do crédito, da dívida pública e do câmbio, e desenvolvidas com o objetivo de promover o crescimento do emprego e da renda, sem gerar desequilíbrios inflacionários e/ ou de balanço de pagamentos de caráter permanente. Para maiores detalhes, ver Ipea (2010).
} 
de prover, por meio de sistemas como o Sistema Único de Saúde (SUS), bens e serviços de forma mais satisfatória para a população. ${ }^{5} \mathrm{E}$ a convergência para um quadro macroeconômico favorável é condição importante, embora longe de suficiente, para a adoção de reformas que tornem o Estado mais eficiente, dotado de um setor público capaz de arrecadar recursos junto à sociedade da forma mais eficaz, justa e progressiva possível, e de fazer uso - também o mais eficaz, justo e progressivo - desses recursos. É necessário estar apto a planejar e se articular com o setor privado a fim de promover o crescimento da economia de maneira equilibrada e estável - tanto do ponto de vista monetário e financeiro quanto de seu setor externo.

O objetivo deste capítulo é traçar um panorama macroeconômico e da saúde (financiamento, gastos, inovação) no Brasil, de modo a subsidiar a elaboração de cenários prospectivos tanto para a macroeconomia quanto para o setor Saúde no país.

Este estudo dá sequência a um trabalho anterior (Teixeira \& Werneck Vianna, 2013), em que se procurou contribuir para a discussão das condições que podem vir a permear o sistema de saúde brasileiro na quarta década do século XXI.

O objetivo principal constituiu-se, portanto, no desenho da configuração básica de uma moldura descritiva do desempenho das variáveis macroeconômicas, de modo a permitir a visualização das alternativas para o sistema nacional de saúde, em termos de limites e possibilidades que condicionariam tanto seu desenvolvimento quanto a elaboração de políticas públicas para o setor.

Para a consecução de tal objetivo, seguiram-se os seguintes passos:

1) resumo do quadro macroeconômico atual e dos principais pontos de vista presentes no debate sobre a economia brasileira;

2) discussão sobre conceitos e métodos utilizados em estudos prospectivos, bem como sobre limites ao uso de cenários para previsão do quadro macroeconômico;

3) levantamento bibliográfico e resenha dos principais trabalhos prospectivos recentes;

4) definição das variáveis a serem utilizadas na construção dos cenários;

5) breve descrição dos cenários alternativos no horizonte de vinte anos.

Neste capítulo, as variáveis apresentadas e analisadas anteriormente foram revistas e atualizadas. Além disso, procurou-se incluir novas variáveis (de particular interesse as referentes a consumo, investimento, inovação, infraestrutura e economia externa).

A primeira seção consiste numa análise retrospectiva, explorando alguns contornos da política macroeconômica na última década, assim como seus condicionantes internos e externos. A segunda seção apresenta um conjunto de dados abarcando aspectos micro e macroeconômicos do setor Saúde: financiamento, gastos, papel estratégico da saúde na inovação. A terceira discute e analisa a construção dos cenários prospectivos a longo prazo, assim definidos como o período de duas décadas à frente.

\footnotetext{
${ }^{5}$ Por sistema entende-se a política pública que engloba os diferentes níveis de governo, com metas, ações e mecanismos de financiamento estabelecidos e consolidados. Uma questão que vem ganhando importância é sobre como integrar as ações e políticas em áreas como educação e segurança pública, tornando-as também sistemas (únicos ou não).
} 


\section{Panorama Macroeconômico: 2003-2013}

Embora não se intencione estabelecer comparações entre diferentes governos, há uma considerável mudança de patamar da economia brasileira em diversos aspectos a partir de 2003, quando se inicia um novo governo federal. Ao final dos oito anos do governo Cardoso (1995-2002), a inflação média, medida pelo Índice Nacional de Preços ao Consumidor Amplo (IPCA), havia sido de 9,1\% ao ano, e o crescimento real do PIB foi, em média, da ordem de 2,3\% ao ano. Em 2010, findos os dois períodos de governo Lula, a inflação anual média ficou em 5,77\% (dentro, portanto, da meta definida pelo Conselho Monetário Nacional), e o crescimento do PIB, também em termos médios anuais, em 4,03\%. Além disso, houve melhoras na distribuição de renda: o índice de Gini recuou de 0,59, em 2002, para 0,53 em 2010.

Tal mudança de patamar, que de resto se verifica também em outras variáveis relevantes (relativas ao setor externo e ao mercado de trabalho, por exemplo), não ocorreu pura e simplesmente pela adoção de políticas, por assim dizer, mais virtuosas por parte do governo do PT, vis-à-vis o governo do PSDB. Na verdade, foi a interação entre grandes mudanças nas condições externas com as quais a economia brasileira se defrontava desde 2003 e pequenas mudanças na orientação da política econômica doméstica que explica, em grande parte, o avanço no controle inflacionário, a recuperação das taxas de crescimento do PIB e a melhora na distribuição de renda registradas na segunda metade da década passada.

No cenário externo, a grande mudança observada foi a intensa aceleração das taxas de crescimento econômico das economias ditas "emergentes", com destaque para a China (Tabela 1). A sustentação do ritmo de crescimento chinês, que naquele momento já vinha há quase duas décadas a taxas anuais de dois dígitos, propiciou uma notável elevação dos preços das commodities, incluindo alimentos, o que representou um enorme impulso para as exportações brasileiras desses produtos.

Tabela 1 - Taxas reais de crescimento econômico comparadas (\% a. a.). Brasil e países selecionados 2005-2013

\begin{tabular}{|c|c|c|c|c|c|c|c|c|c|c|}
\hline Crescimento do PIB & $\begin{array}{c}\text { Média } \\
1995-2004\end{array}$ & 2005 & 2006 & 2007 & 2008 & 2009 & 2010 & 2011 & 2012 & 2013 \\
\hline Economias avançadas & 2,8 & 2,8 & 3,0 & 2,7 & 0,1 & $-3,4$ & 3,0 & 1,7 & 1,5 & 1,2 \\
\hline Economias emergentes & 4,9 & 7,3 & 8,3 & 8,7 & 5,8 & 3,1 & 7,5 & 6,2 & 4,9 & 4,5 \\
\hline China & 9,2 & 11,3 & 12,7 & 14,2 & 9,6 & 9,2 & 10,4 & 9,3 & 7,7 & 7,6 \\
\hline Índia & 6,2 & 9,3 & 9,3 & 9,8 & 3,9 & 8,5 & 10,5 & 6,3 & 3,2 & 3,8 \\
\hline Brasil & 2,5 & 3,2 & 4,0 & 6,1 & 5,2 & $-0,3$ & 7,5 & 2,7 & 0,9 & 3,0 \\
\hline México & 2,4 & 3,2 & 5,0 & 3,1 & 1,2 & $-4,5$ & 5,1 & 4,0 & 3,6 & 1,2 \\
\hline
\end{tabular}

Fonte: elaboração dos autores com base em dados do IMF, 2014. 
Adicionalmente, o setor exportador brasileiro - notadamente o vinculado às commodities metálicas - foi beneficiado, num primeiro momento, por uma posição excepcionalmente favorável da taxa de câmbio, ocasionada pela intensa desvalorização do real desencadeada pelas incertezas e temores dos mercados financeiros diante da transição de governos em fins de 2002 (Gráfico 1).

Gráfico 1 - Taxa nominal de câmbio R\$/US\$ - médias anuais - 2002-2013

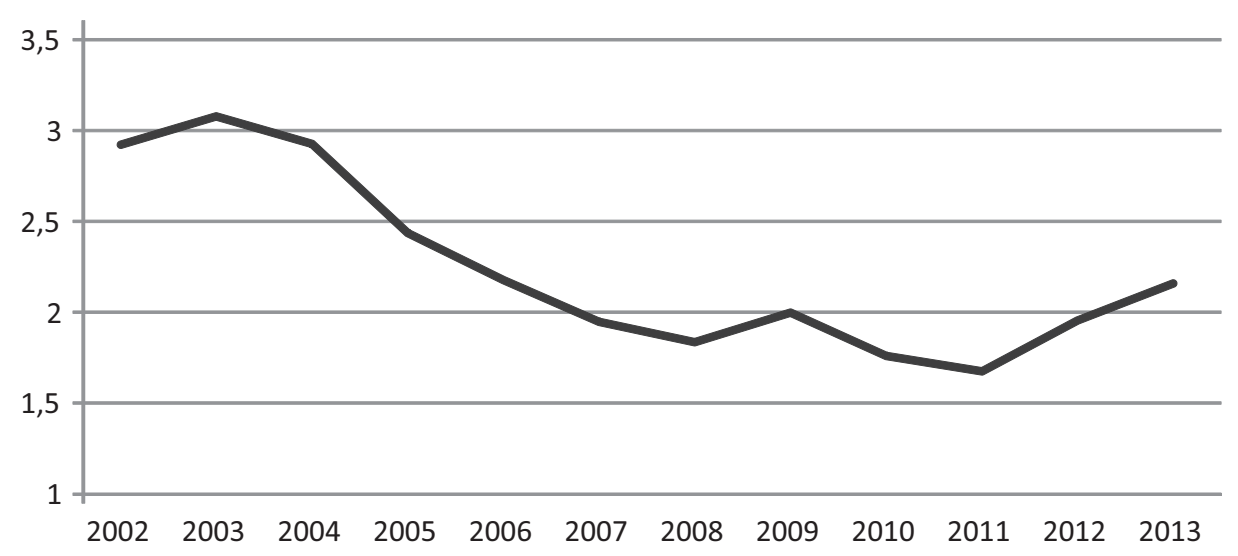

Fonte: elaboração dos autores com base em dados do Banco Central do Brasil - Sistema Gerador de Séries Temporais (BCB - SGS).

Esse duplo impulso, dado pela conjugação de uma taxa de câmbio desvalorizada com um cenário de termos de troca favoráveis, foi bem aproveitado pelo setor exportador de bens primários, o que se traduziu numa efetiva redução das vulnerabilidades externas da economia brasileira, que marcaram a década de 1990. A substantiva elevação do nível das reservas internacionais constitui em si um dado revelador, embora não o único, dessa nova realidade, que de resto permitiu à economia brasileira atravessar, sem maiores sobressaltos, os piores anos da severa crise internacional desencadeada nas economias avançadas a partir de 2007.

Do ponto de vista da gestão da política macroeconômica, os primeiros anos do governo Lula foram marcados pela manutenção, e em alguns aspectos até aprofundamento, do arcabouço do governo anterior. O assim chamado "tripé" - regime monetário de metas de inflação, câmbio flutuante e disciplina fiscal - foi mantido, com algumas nuances, como, por exemplo, o estabelecimento de uma meta maior de superávit primário. A política econômica reafirmava, assim, o compromisso prioritário com a estabilidade de preços, em detrimento de objetivos relacionados ao crescimento da renda e do emprego. A política monetária, nesse sentido, constituía-se no instrumento-chave para esse compromisso, cabendo às políticas cambial e fiscal funções meramente coadjuvantes.

A manutenção de taxas básicas de juros (nominais e reais) em patamares elevados tem sido uma característica distintiva da política econômica brasileira, ainda que a tendência, na última década, tenha sido de (relativa) flexibilização. Além de atuar diretamente na contenção da demanda agregada, reduzindo o nível de atividade, a política de juros altos atua também como fator de atração de capitais externos de curto prazo. Esses capitais, ao entrarem na economia, ampliam a oferta de divisas 
e consequentemente contribuem para a apreciação da taxa de câmbio, o que por sua vez torna mais baratos os bens importados. A valorização do real, portanto, é um subproduto desejado da política monetária (ainda que isto não seja declarado pelo Banco Central do Brasil - BCB), na medida em que constitui poderoso instrumento auxiliar no controle inflacionário.

Não obstante, é inequívoca uma tentativa de mudança de orientação da política monetária a partir de 2010, quando se inicia o governo Dilma na Presidência da República. Os juros reais, que ficaram em média na casa de $8,5 \%$ no período 2003-2010, despencaram para 3,1\% no triênio 20112013, movimento esse cuja maior explicação deriva da redução significativa da taxa básica nominal (Selic). Em que pese uma recuperação, ainda que modesta, das taxas de investimento, é fato que o crescimento econômico tem se mantido em ritmo lento (Gráfico 2). ${ }^{6}$

Gráfico 2 - PIB-Brasil - variação real anual (\%) - 2002-2012

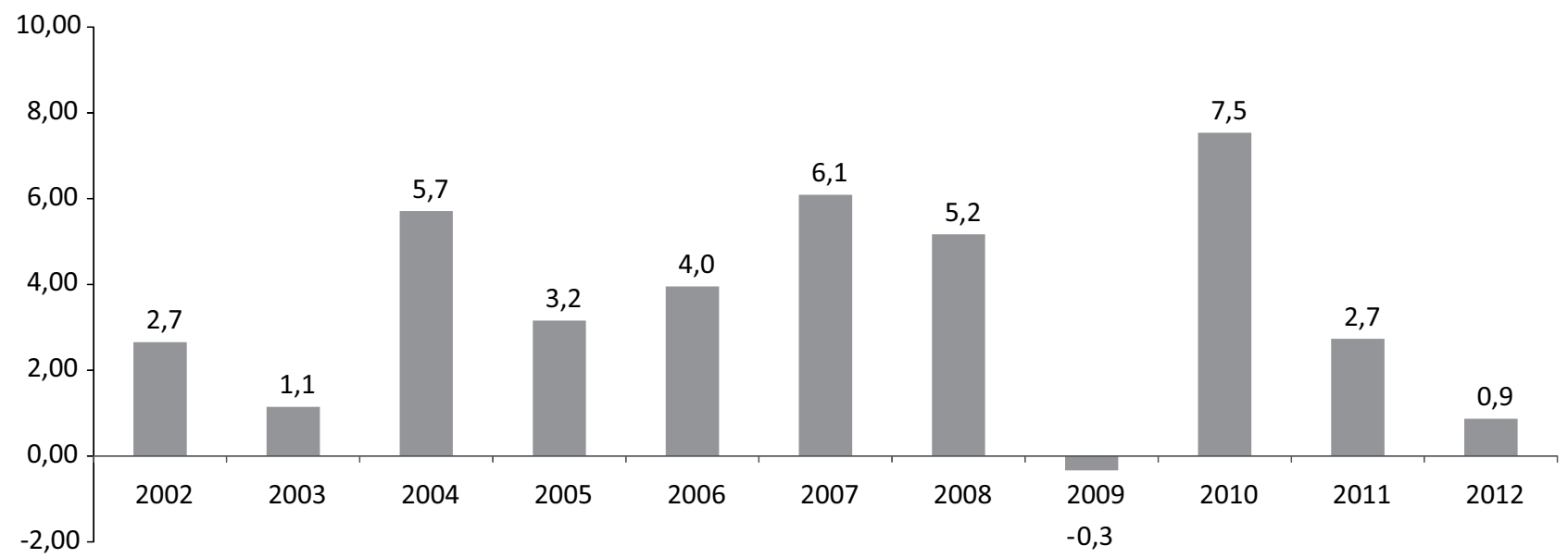

Fonte: elaboração dos autores com base em dados do Sistema de Contas Nacionais do IBGE.

Resta pouca dúvida, no entanto, de que o governo Lula soube, na medida do possível, aproveitar o vigoroso impulso dado à economia pelo setor externo (as "grandes mudanças" aludidas anteriormente) para, por meio de intervenções pontuais (as "pequenas mudanças"), lograr dinâmicas positivas nos níveis de emprego e de renda.

Por mais positivas que tenham sido tais dinâmicas, elas foram insuficientes para alterar estruturalmente o mercado de trabalho. Prevalecem ainda empregos de baixa remuneração e alta rotatividade, o que restringe o crescimento da produtividade e, consequentemente, a expansão da economia a taxas maiores e sustentadas. Indícios claros nesse sentido são os incrementos modestos do rendimento médio dos trabalhadores e da parcela no PIB da renda do trabalho (gráficos 3 e 4).

\footnotetext{
${ }^{6}$ Esse quadro por certo reflete ainda os efeitos da crise internacional e a consequente redução do ritmo de crescimento da economia global.
} 
Gráfico 3 - Rendimento médio real efetivo das pessoas ocupadas nas regiões metropolitanas $(\mathrm{R} \$)-2003-2013$

$$
2.500,0
$$

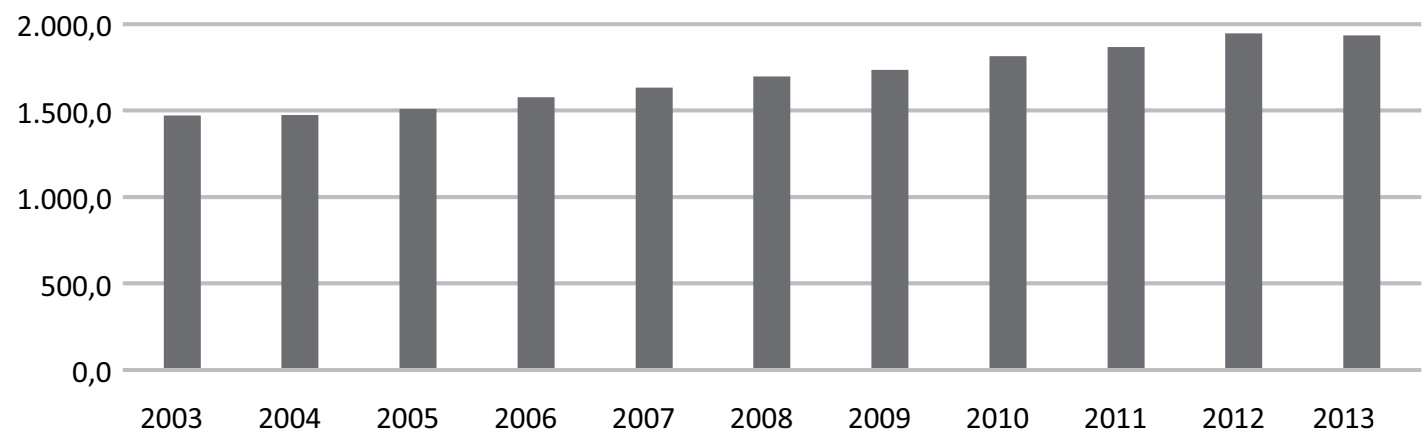

Fonte: elaboração dos autores com base em dados da Pesquisa Mensal de Emprego do IBGE.

Gráfico 4 - Rendimentos do trabalho (\% do PIB) - 2003-2009

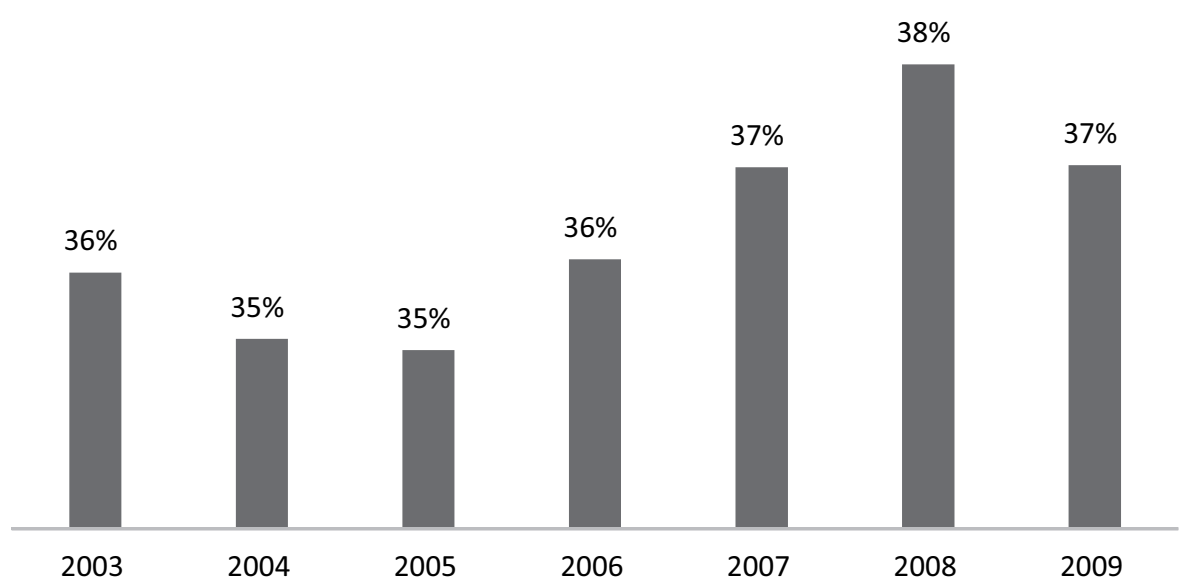

Fonte: elaboração dos autores com base em dados da Pesquisa Mensal de Emprego do IBGE.

Há que se destacar, ainda, a expressiva expansão do crédito oferecido pelo setor financeiro (público e privado), assim como do ritmo de inclusão de parcelas crescentes da população ao sistema bancário (gráficos 5 e 6). A combinação destes fenômenos com o aumento do emprego forjou o regime de crescimento do período 2003-2010, baseado principalmente no consumo das famílias. 
Gráfico 5 - Crédito do sistema financeiro (\% do PIB) - 2003-2012

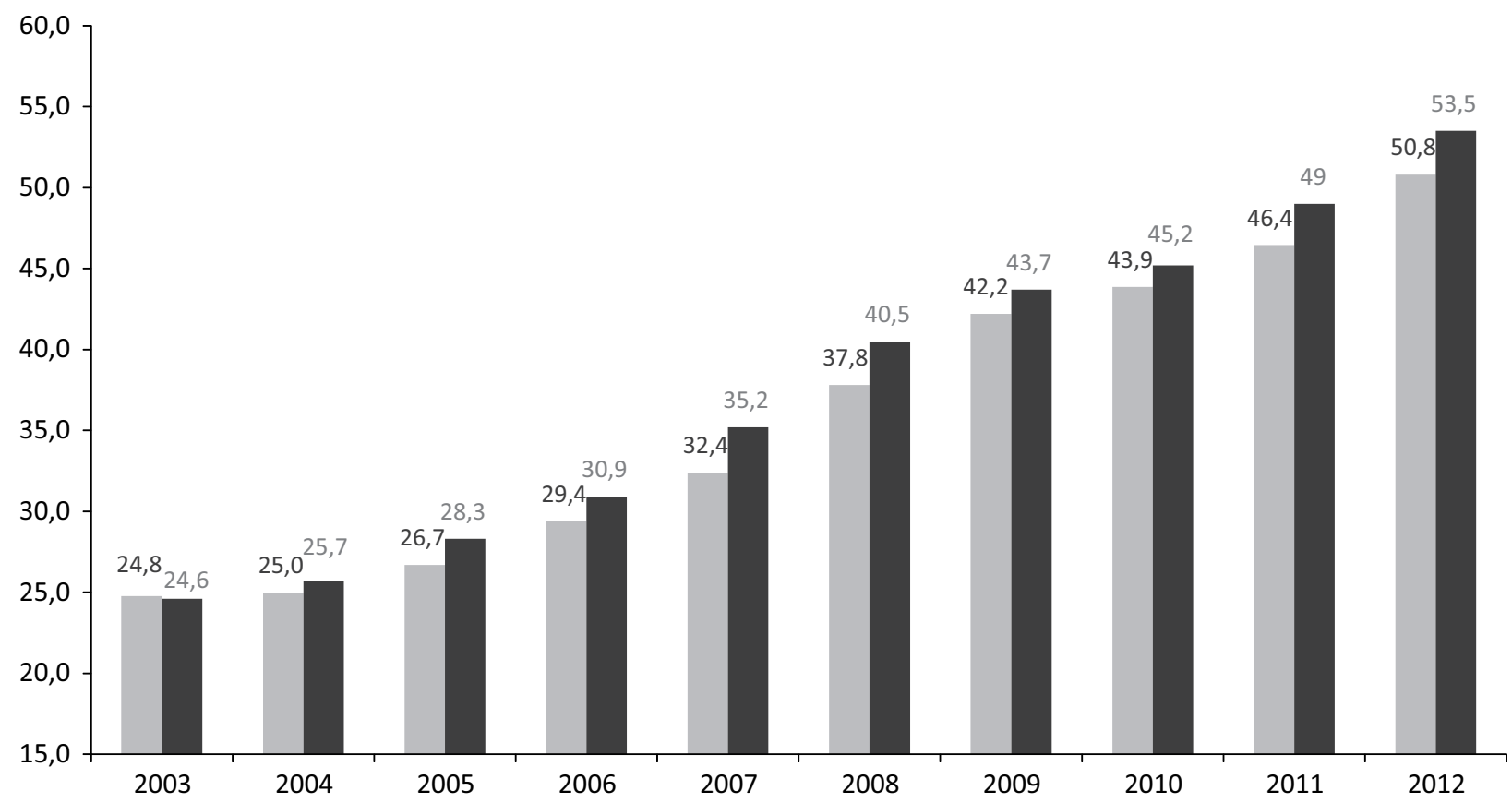

Crédito do sistema financeiro/PIB - \% - média do ano

Crédito do sistema financeiro/PIB - \% - dezembro do ano

Fonte: elaboração dos autores com base em dados do Banco Central do Brasil - Sistema Gerador de Séries Temporais (BCB - SGS).

Gráfico 6 - Inclusão financeira* (\% população) - 2006-2012

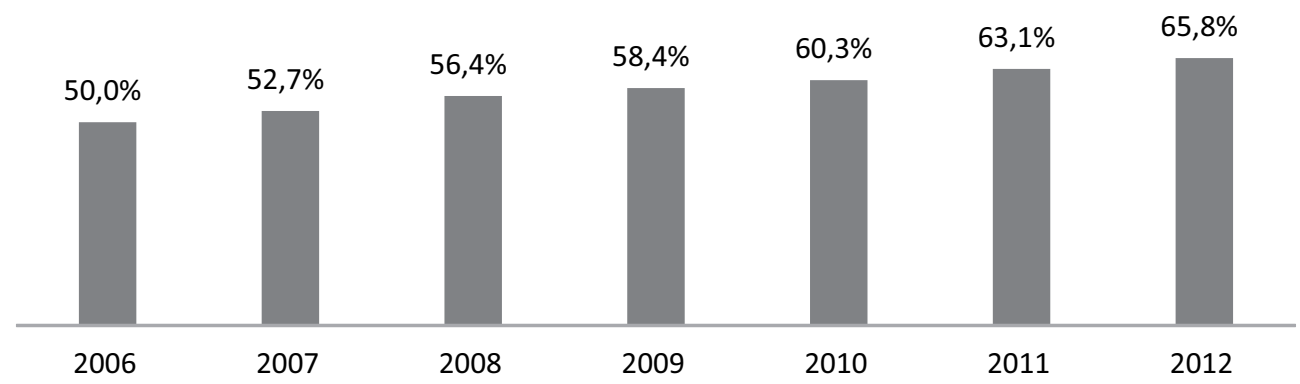

\footnotetext{
* Percentual da população residente com relacionamentos bancários, incluindo conta corrente, conta poupança ou outro relacionamento bancário.

Fonte: elaboração dos autores com base em dados do Cadastro de Clientes do Sistema Financeiro Nacional do Banco Central do Brasil (CPFs ativos ao final de cada ano) e da Diretoria de Pesquisas, Coordenação de População e Indicadores Sociais (população residente).
} 
A interação dessas políticas, associada ainda a outros fatores, como a recuperação do valor real do salário mínimo e a expansão de programas distributivos como o Bolsa Família, propiciou a melhora, ainda que modesta, de importantes indicadores sociais. Houve quedas nos segmentos pobres e extremamente pobres da população, e melhora na distribuição de renda medida pelo índice de Gini (Tabela 2).

Tabela 2 - Parcelas da população por estratos de renda. Brasil - 2003 e 2011

\begin{tabular}{|l|c|c|c|}
\hline \multirow{2}{*}{\multicolumn{1}{c|}{ Estratos }} & \multicolumn{3}{|c|}{ Famílias } \\
\cline { 2 - 4 } & $2003(\%)$ & $2011(\%)$ & Variação (p. p.) \\
\hline Extremamente pobres & 5,5 & 2,6 & $-2,9$ \\
\hline Pobres & 12 & 4,4 & $-7,7$ \\
\hline Vulneráveis & 50,5 & 44,8 & $-5,6$ \\
\hline Não pobres & 32 & 48,2 & 16,2 \\
\hline Total & 100 & 100 & - \\
\hline Coeficiente de Gini & 0,576 & 0,523 & $-9,2$ \\
\hline
\end{tabular}

Nota: os quatro estratos foram definidos pelos autores com base na renda domiciliar per capita: extremamente pobres (famílias com renda inferior a $\mathrm{R} \$ 70,00$, em reais de 2011); pobres (renda maior ou igual a $\mathrm{R} \$ 70,00$ e inferior a $R \$ 140,00$ ); vulneráveis (renda maior ou igual a $R \$ 140,00$ e menor que $R \$ 560,00$ ); e não pobres (renda maior ou igual a $\mathrm{R} \$ 560,00)$. A linha de vulnerabilidade foi estabelecida como quatro vezes o valor da linha de pobreza.

Fonte: Souza \& Osório, 2013: 146.

\section{Aspectos Microeconômicos: financiamento, gastos e papel estratégico do setor Saúde na inovação}

O desenho do sistema de proteção social contemplado na Constituição Federal de 1988 baseia-se num modelo contributivo para as aposentadorias, mas com regime especial para os trabalhadores rurais, universal na saúde e sujeito a controles de insuficiência de renda no caso das transferências assistenciais (Benefício da Prestação Continuada da Lei Orgânica da Assistência Social - BPC/Loas). Já o financiamento da seguridade social foi estruturado com base em contribuições diretas ao sistema previdenciário (contribuições dos empregados e empregadores ao Instituto Nacional do Seguro Social - INSS - e contribuições ao regime de previdência do setor público), impostos e taxas vinculados à seguridade social - Contribuição para Financiamento da Seguridade Social (Cofins), Contribuição Social sobre o Lucro Líquido (CSLL), Programa de Integração Social/Programa de Formação do Patrimônio do Servidor Público (PIS/Pasep) e Fundo de Pobreza - e em tributos não previamente vinculados à seguridade social.

A diversificação das fontes de arrecadação representou uma conquista de grande importância, na medida em que reduziu a sujeição do volume de receitas às oscilações do ciclo econômico, ${ }^{7}$ e

\footnotetext{
7 Segundo Gentil e Santos (2009: 153), "a diversificação das fontes de arrecadação do sistema de seguridade social, com a inclusão de contribuições sociais incidentes sobre o lucro e o faturamento, foi uma conquista de grande importância, porque a previdência financiada unicamente pela folha de salários entrou em crise nos anos 1980, quando a economia brasileira enfrentou recessão e o emprego desabou".
} 
simultaneamente ampliou os recursos ao financiamento da seguridade social. A construção dessa compatibilidade entre a política econômica e o aumento dos recursos disponíveis para a seguridade social foi uma das grandes responsáveis pela melhora consistente da distribuição de renda nos últimos vinte anos, possibilitando a viabilização do aumento das transferências públicas para as camadas mais pobres da população e o pagamento do serviço da dívida pública (Gentil \& Santos, 2009).

Apesar dos avanços do Sistema Único de Saúde, o aumento dos gastos privados é uma questão real, que vem ganhando importância crescente, uma vez que se torna um item de despesa extremamente oneroso (e regressivo) no orçamento das famílias (Tabela 3).

Tabela 3 - Gastos em saúde, públicos e privados, no Brasil e no mundo - 2001 e 2011

\begin{tabular}{|l|r|r|r|r|}
\hline & \multicolumn{3}{|c|}{ Brasil } & \multicolumn{2}{|c|}{ Mundo } \\
\hline & 2001 & 2011 & 2001 & 2011 \\
\hline Gastos em saúde/Gastos totais (\%) & 4,7 & 8,7 & 12,4 & 15,3 \\
\hline Planos privados de saúde/Gastos privados em saúde (\%) & 35,0 & 40,4 & 39,6 & 37,2 \\
\hline Gasto governamental em saúde per capita (US\$) & 96,3 & 512,6 & 285,2 & 614,8 \\
\hline
\end{tabular}

Nota: valores expressos em dólares americanos com base em taxas médias de câmbio de cada ano.

Fonte: elaboração dos autores com base em dados do Global Health Observatory Data Repository da Organização Mundial da Saúde.

Em relação às despesas familiares, os dados da Pesquisa de Orçamentos Familiares 2008-2009 (IBGE, 2012) mostram que:

1) $40 \%$ das famílias com menor rendimento destinam $74,2 \%$ desses gastos para medicamentos, enquanto entre os $10 \%$ com maiores rendas esse percentual é de 33,6\%;

2) O acesso aos planos de saúde costuma ser limitado, concorrendo para isso a alta proporção de despesas com alimentação, habitação e transporte no orçamento doméstico das famílias. As despesas com planos de saúde correspondem a $7 \%$ dos gastos dos $40 \%$ mais pobres, contra $42,3 \%$ dos $10 \%$ mais ricos.

A expansão dos gastos globais se reflete também no surgimento de desequilíbrios no setor industrial ligado ao complexo da saúde. Os gargalos produtivos e a falta de investimentos em áreas de alto conteúdo tecnológico, como a produção de farmoquímicos, impactam fortemente a balança comercial com o aumento crescente do conteúdo importado.

O aumento das importações nesses setores evidencia tais gargalos. Segundo Carneiro (2010), o setor Equipamentos Médicos e de Hospital, Automação Industrial e Precisão teve um aumento do coeficiente de penetração de importações de 32,7 pontos percentuais (p. p.) para 35,1 p. p. entre 1996 e 2008. Isso mostra que "a indústria brasileira está substituindo a produção doméstica de insumos por importados de maneira rápida" (Serrano \& Summa, 2011: 29), o que reforça o desafio ainda existente em termos de política industrial para o país. 


\section{Cenários Prospectivos}

As técnicas de construção de cenários usualmente aplicadas em estudos prospectivos percorrem uma trajetória em que os cenários aparecem como resultado. As metodologias podem variar, conforme a orientação e a percepção teórica do autor, mas é sempre de uma dada combinação de fatores que resulta a construção do cenário.

As limitações dessa técnica são evidentes e já foram destacadas por muitos autores. Simonsen (1972), quatro décadas atrás, já mostrava o erro em que incorrem os economistas quando formulam projeções para o comportamento da economia a longo prazo, baseadas em evidências tópicas a curto prazo. Rigorosamente falando, e considerando o que os economistas chamam de curto e longo prazo, tal como os concebeu Alfred Marshall (1985), em seu Principles of Economics, não se pode cometer o equívoco de imaginar que uma tendência a longo prazo seja uma sequência de tendências a curto prazo; nem que, portanto, conhecendo-se as tendências que configuram uma dada conjuntura, seja possível estabelecer uma trajetória para o futuro a longo prazo.

O futuro é rigorosamente marcado pela incerteza - que não pode ser definida em termos probabilísticos. E essa incerteza é vivida pelos agentes econômicos de forma não necessariamente convergente e coordenada. Ao contrário, os agentes econômicos formam suas expectativas de modo diferenciado e agem de acordo com essas expectativas. Só que suas decisões (ou indecisões) acarretam custos, e, caso se frustrem, não haverá como corrigi-las em curto prazo. O comportamento dos agentes econômicos não se coaduna, portanto, com modelos de expectativas adaptativas, nem, muito menos, com os de expectativas racionais. A incerteza, de acordo com Keynes, é uma força endógena no funcionamento do sistema capitalista, e é ela a responsável pela instabilidade própria à evolução da economia.

Se observarmos a situação por que passa a economia mundial hoje - e, dentro dela, o estado em que se encontram os países centrais -, pode-se facilmente concluir que os fatores de instabilidade são múltiplos, variados e de difícil previsibilidade. Mais do que isso, é difícil prever o impacto que cada um desses fatores terá nas economias da periferia, mesmo em um país com sólidos fundamentos macroeconômicos como o Brasil.

Exatamente por isso - e porque estudos prospectivos e construção de cenários devem ser utilizados como ferramentas para o planejamento e não como exercício de futurologia - foi adotado aqui o caminho inverso. O ponto de partida é a definição dos cenários - ou, mais precisamente, do cenário otimista - com o dimensionamento das variáveis relevantes; só depois é que foi estabelecida a trajetória que a economia brasileira deve percorrer para alcançá-los, em termos de decisões de política econômica e de fatos estruturais impactantes. Alternativamente ao cenário otimista, foram interpostos obstáculos (inclusive pela não adoção de políticas adequadas) que impediriam a economia brasileira de atingir o cenário mais favorável.

A literatura frisa a necessidade de mecanismos de acompanhamento e monitoramento, como instrumentos indispensáveis para o bom uso das técnicas de estudos prospectivos e construção de cenários (Teixeira \& Werneck Vianna, 2013). Dada a metodologia aqui adotada (que parte do cenário para a trajetória), mais importante ainda será o acompanhamento do desempenho das variáveis. Só assim 
poder-se-á garantir que fatos imprevistos, novos desenhos no quadro internacional ou fatores ligados à incerteza e à instabilidade inerentes ao capitalismo serão levados em conta e inseridos na prospecção do futuro. Só assim essas ferramentas tornar-se-ão de fato úteis para o planejamento econômico.

No que concerne às possibilidades de o país ingressar num ciclo longo de crescimento sustentado, isto é, sem gerar pressões sobre a inflação nem sobre o balanço de pagamentos, há um relativo consenso, baseado na evidência empírica brasileira, de que o crescimento continuado a taxas próximas de $5 \%$ ao ano requer uma taxa de investimento (formação bruta de capital em relação ao PIB) em torno de $25 \%$ do PIB. E, em que pese o fato de o investimento agregado no Brasil vir registrando, desde 2004, taxas de crescimento bem superiores às do PIB (à exceção de 2009 e 2012), ainda assim o nível atual do investimento permanece em patamares considerados baixos (pouco superior a 18\% do PIB, em 2012), em relação tanto à média dos países em desenvolvimento, quanto à média histórica do país.

A questão de fundo em relação ao investimento no Brasil remete, em última análise, ao padrão de crescimento que o país vem apresentando nos últimos anos. Assim, a expansão recente do investimento está majoritariamente associada aos setores que mais têm contribuído para o crescimento da economia: agronegócio e extrativismo mineral. Com efeito, os investimentos nos setores intensivos em recursos naturais e em escala respondem por cerca de $80 \%$ do total da formação bruta de capital.

O investimento é a variável-chave de uma economia; inserido numa estratégia adequada, funciona como ponte intertemporal entre diferentes estágios de desenvolvimento, permitindo a superação de gargalos de oferta e a implementação de transformações estruturais. Nesse sentido, o grande desafio para o desenvolvimento brasileiro é a expansão significativa do investimento em três setores estratégicos: infraestrutura urbana e logística, energia e indústria de transformação. É absolutamente imprescindível a liderança do Estado nesse processo, em particular nos dois primeiros setores.

\section{Cenário otimista e possível}

- O PIB crescerá a uma taxa entre 3 e 4\% a. a. - intervalo em que situa a média verificada no período de dez anos encerrado em 2013-3,5\%. Isso implica um crescimento vigoroso do nível de atividade econômica (vis-à-vis a atual conjuntura) e, portanto, um enfrentamento virtuoso dos obstáculos e restrições decorrentes da crise internacional, bem como a introdução de correções na implementação dos instrumentos de política econômica.

- O PIB alcançará em 2033 o expressivo valor de R\$ 10.477 bilhões, a preços constantes de 2013.

- A renda per capita chegará a $\mathrm{R} \$ 46.379$, a preços constantes de 2013, com uma população pouco superior a 225 milhões de habitantes. Esse valor corresponde (a preços constantes de 2013, em dólares e em reais) a pouco maisde 20 mil dólares anuais e poderá significar, para a população brasileira, a possibilidade de desfrutar de níveis de vida significativamente superiores aos de hoje. A condição para que isso ocorra é que a distribuição de renda também melhore, tanto no conceito de distribuição pessoal quanto no de distribuição funcional.

- O coeficiente de Gini, utilizado normalmente para a distribuição pessoal da renda, deverá chegar a 0,40. Com isso, ele estará situado em patamar mais favorável do que em países da 
América Latina, como Argentina $(0,522)$, Venezuela $(0,491)$ e Uruguai $(0,446)$, e próximo aos observados em países de maior desenvolvimento, como França $(0,327)$, Inglaterra $(0,36)$ e Estados Unidos $(0,408)$.

- A participação dos rendimentos do trabalho no PIB - que serve como proxy para a distribuição funcional da renda - poderá chegar a $50 \%$, o que significa um crescimento expressivo, mas possível.

- A hipótese adotada para a projeção do salário mínimo - que é a da continuidade do acordo firmado com os sindicatos - levará o salário mínimo ao valor de R\$1.441,00 em 2033.

- O rendimento médio do pessoal ocupado terá em 2033 um desempenho positivo, apresentando um crescimento superior ao da renda per capita.

- Níveis de emprego e taxas de desemprego apresentarão resultados favoráveis em 2033, com aumento substancial do primeiro - principalmente no segmento de trabalhadores com carteira assinada - e redução significativa do segundo indicador.

- A taxa básica de juros convergirá para a taxa média praticada nos países da Organização para a Cooperação e Desenvolvimento Econômico (OCDE) (1,65\%), o que indica ter havido uma alteração radical nas condições fiscais e financeiras do Estado brasileiro: o serviço da dívida pública terá experimentado uma redução significativa, e as contas públicas apresentarão um resultado primário próximo de zero.

- O Estado, em consequência, terá readquirido sua capacidade de endividamento e de utilização do gasto como instrumento de promoção do crescimento e do emprego.

- A taxa de câmbio terá sofrido pronunciada desvalorização, condizente com as políticas macroeconômicas centradas no crescimento econômico e na promoção do emprego; seu valor oscilará em torno de $\mathrm{R} \$ 2,50$ por dólar.

- O comportamento do balanço comercial é de difícil previsão, não apenas em virtude da instabilidade do comércio mundial em tempos de crise, mas principalmente porque, se o desenvolvimento experimentado pelo país incrementará as exportações (principalmente de manufaturados e serviços de maior valor agregado), ampliará também as importações, principalmente de bens de capital e bens intermediários, indispensáveis à sustentação do crescimento.

- O resultado da conta corrente do balanço de pagamentos apontará para uma situação de maior conforto para a gestão das políticas macroeconômicas.

- A inflação, controlada não apenas pelos instrumentos convencionais de política monetária, mas por políticas adequadas à consolidação das tendências de crescimento da economia, ocupará o centro da meta.

- Aproveitamento das condições favoráveis internacionais para a promoção de crescimento econômico elevado com melhoria dos padrões socioeconômicos do país: ampliação do espaço fiscal para investimentos (ampliação da cobertura e qualidade do sistema público de saúde), melhorias em infraestrutura urbana, maior acesso a bens e serviços públicos de qualidade, salto em educação, amplo investimento em inovação, realização das metas do Plano Brasil Maior. 


\section{Cenário pessimista e plausível}

- O PIB crescerá a uma taxa de 0,56\%, que é exatamente a taxa de crescimento populacional. Isso significa que as vicissitudes do quadro internacional não terão um enfrentamento adequado e que recrudescerá o viés conservador e monetarista da política econômica.

- O valor do PIB no horizonte considerado será de R\$ 5.945 bilhões, a preços de 2013.

- A renda per capita permanecerá a mesma de 2013: $\mathrm{R} \$ 26.316$, o que significa um empobrecimento relativo da população brasileira, e acarretará impactos negativos na distribuição de renda.

- A tendência à melhoria da distribuição pessoal da renda, medida pelo coeficiente de Gini, será, portanto, detida, e esse indicador estabilizará no patamar de 0,60.

- Igual tendência experimentará a distribuição funcional da renda, medida pela participação dos rendimentos do trabalho no PIB, que, se não cair, deverá na melhor hipótese permanecer no mesmo nível de 2013.

- O salário mínimo, nos marcos da hipótese anteriormente mencionada, relativa à continuidade do acordo com os sindicatos, não ultrapassará $\mathrm{R} \$ 810,00$, o que pode ser um fator a alimentar tensões sociais e disputas trabalhistas.

- O rendimento médio do pessoal ocupado tenderá a crescer a uma taxa inferior à da renda por habitante, em decorrência tanto do baixo valor do salário mínimo, que baliza e serve como piso salarial no mercado de trabalho, quanto das pressões oriundas da transição demográfica que se encontrará em fase avançada. Em 2033, no cenário mais provável (o que os demógrafos denominam variante média populacional), a estrutura etária da população brasileira estará fortemente concentrada nas faixas adultas (grupos etários entre 15-19 e 50-54 anos); com o baixo crescimento, não será possível evitar as implicações da dinâmica demográfica em termos de perda de poder de barganha dos trabalhadores nas negociações salariais e de aumento do grau de informalização e de precarização no mercado de trabalho.

- Nível de emprego e taxa de desemprego refletirão as condições negativas do desempenho da economia brasileira, reduzindo-se o primeiro e elevando-se a segunda. A ausência de crescimento do emprego está relacionada com as tendências negativas dos indicadores de distribuição de renda e do rendimento médio do pessoal ocupado.

- A taxa básica de juros permanecerá nos níveis atuais (11\% a. a.), em decorrência da continuidade de políticas conservadoras que priorizam o controle inflacionário e a atração de capitais externos para o fechamento do balanço de pagamentos.

- As contas públicas continuarão a sofrer progressiva deterioração, em virtude tanto do baixo crescimento quanto da permanência das taxas de juros em patamares elevados. Superávits primários crescentes continuarão a ser a meta da política econômica para permitir o pagamento das despesas financeiras relacionadas ao serviço da dívida pública.

- A taxa de câmbio permanecerá sobrevalorizada, mantendo-se em níveis entre $\mathrm{R} \$ 1,80$ e $\mathrm{R} \$ 2,00$ por dólar (a valores de 2013).

- As contas externas (balanço comercial e balanço das transações correntes) não sofrerão grande alteração. 
- A inflação ocupará o centro da meta.

- A restrição ao crescimento econômico diminuirá severamente o (já pequeno) espaço fiscal para investimentos sociais; tenderá a haver piora dos indicadores de inovação (especialização regressiva da estrutura produtiva), da infraestrutura urbana e social e das condições de vida da população, bem como diminuição da cobertura e da qualidade dos serviços públicos de saúde.

\section{Cenário conservador e provável}

- O PIB crescerá a uma taxa inferior à da média dos últimos dez anos - 2,0\% a. a. - mas superior à taxa de crescimento demográfico. O impacto da crise internacional sobre a economia brasileira será significativo e a adoção de instrumentos de política econômica voltados para o crescimento e a promoção do emprego será tímida.

- O PIB registrará, em 2033, o montante de R 7.900 bilhões.

- A renda per capita crescerá, mantendo-se a tendência dos últimos anos, e alcançará o valor de $\mathrm{R} \$ 34.972$.

- A distribuição de renda, em ambos os conceitos, continuará a melhorar: o coeficiente de Gini, tal qual no cenário anterior, estabilizará em 0,60 , e a participação dos rendimentos do trabalho no PIB experimentará moderada melhoria.

- O salário mínimo vigente em 2013 será de $\mathrm{R} \$$ 1.076,00, respeitada a hipótese adotada nos demais cenários.

- O rendimento médio do pessoal ocupado tenderá a acompanhar, em maior ou menor grau, a evolução da renda por habitante. Ainda que menos intensos do que no cenário pessimista, os efeitos da transição demográfica também se farão sentir, e o mercado de trabalho dificilmente será capaz de absorver a população em idade laboral (e particularmente as camadas mais jovens), que constituirá a larga maioria da população total. As pressões daí advindas implicarão também o aumento da informalidade e da precarização nas relações de trabalho.

- O nível de emprego e taxa de desemprego permanecerão nos mesmos patamares em que se encontram na atualidade.

- A taxa básica de juros convergirá para a média das que são praticadas pelos países emergentes, chegando a 4,35\% a. a.; esse nível é consistente com as projeções de crescimento moderado da economia.

- A taxa de câmbio oscilará entre R \$2,00 e R \$2,20 por dólar, o que significa uma leve desvalorização.

- As contas externas (balanço comercial e balanço das transações correntes) não sofrerão grande alteração.

- Política macroeconômica comprometida com o desenvolvimento socioeconômico possibilitará melhoria dos bens e serviços públicos, porém limitada a um crescimento econômico mais moderado com menor espaço fiscal (menor ampliação da cobertura e qualidade do sistema público de saúde). Baixo investimento em inovação, cobertura e qualidade dos bens e serviços públicos comprometidas, gargalos no setor de infraestrutura e mobilidade urbana, impactos na qualidade de vida da população. Crescimento econômico não vem acompanhado de uma mudança estrutural de desenvolvimento (Quadro 1). 
Quadro 1 - Cenários macroeconômicos para 2033

\begin{tabular}{|c|c|c|c|c|}
\hline Variável relevante & Situação atual ${ }^{1}$ & $\begin{array}{l}\text { Cenário otimista e } \\
\text { possível }\end{array}$ & $\begin{array}{l}\text { Cenário pessimista } \\
\text { e plausível }\end{array}$ & $\begin{array}{c}\text { Cenário } \\
\text { conservador e } \\
\text { provável }\end{array}$ \\
\hline PIB & $\mathrm{R} \$ 5.316$ bilhões & $\mathrm{R} \$ 10.477$ bilhões & $\mathrm{R} \$ 5.945$ bilhões & R\$ 7.900 bilhões \\
\hline População & 201.032.714 & & 225.896 .169 & \\
\hline Renda per capita & $\mathrm{R} \$ 26.315$ & $\mathrm{R} \$ 46.379$ & $\mathrm{R} \$ 26.315$ & $\mathrm{R} \$ 34.972$ \\
\hline Taxa de crescimento & $2,3 \%$ a. a. & $3,5 \%$ a. a & $0,56 \%$ a. a. & $2,0 \%$ a. a. \\
\hline Taxa de desemprego & $6,7 \%$ & Cai & Aumenta & $\begin{array}{l}\text { Permanece no } \\
\text { mesmo nível }\end{array}$ \\
\hline Salário mínimo & $\mathrm{R} \$ 724,00$ & $\mathrm{R} \$ 1.441,00$ & $\mathrm{R} \$ 810,00$ & $\mathrm{R} \$ 1.076,00$ \\
\hline $\begin{array}{l}\text { Rendimento médio do pessoal } \\
\text { ocupado }\end{array}$ & $\mathrm{R} \$ 1.527,00$ & $\begin{array}{l}\text { Crescimento } \\
\text { superior ao da renda } \\
\text { per capita }\end{array}$ & $\begin{array}{l}\text { Crescimento inferior } \\
\text { ao da renda per } \\
\text { capita }\end{array}$ & $\begin{array}{l}\text { Crescimento } \\
\text { semelhante ao da } \\
\text { renda per capita }\end{array}$ \\
\hline Índice de Gini & $0,543^{2}$ & 0,40 & 0,60 & 0,60 \\
\hline $\begin{array}{l}\text { Rendimentos do trabalho } \\
\text { (participação no PIB) }\end{array}$ & $34 \% \%^{3}$ & $\begin{array}{l}\text { Melhoria } \\
\text { pronunciada }\end{array}$ & $\begin{array}{l}\text { Permanece no } \\
\text { mesmo nível }\end{array}$ & Melhoria moderada \\
\hline $\begin{array}{l}\text { Resultado primário (governo } \\
\text { central) }\end{array}$ & R\$ 91.300 milhões & $\begin{array}{c}\text { Cai } \\
\text { significativamente }\end{array}$ & Aumenta & $\begin{array}{l}\text { Permanece no } \\
\text { mesmo nível }\end{array}$ \\
\hline Resultado primário (\% PIB) & $1,90 \%$ & $\begin{array}{c}\text { Cai } \\
\text { significativamente }\end{array}$ & Aumenta & Cai moderadamente \\
\hline Serviço da dívida pública & R\$ 248,9 milhões & $\begin{array}{c}\text { Cai } \\
\text { significativamente }\end{array}$ & Aumenta & Cai moderadamente \\
\hline Taxa de juros (Selic) & $11 \%{ }^{4}$ & $1,65 \%$ & $11 \%$ & $4,35 \%$ \\
\hline Taxa de câmbio & $\mathrm{R} \$ 2,16 / \mathrm{US} \$ 1,00$ & $\mathrm{R} \$ 2,50$ & $\mathrm{R} \$ 1,80$ & $\mathrm{R} \$ 2,00$ \\
\hline Saldo do balanço comercial & US $\$ 2,56$ bilhões & Sobe & \multicolumn{2}{|c|}{ Permanece no mesmo nível } \\
\hline Déficit em transações correntes & US $\$ 81,37$ bilhões & Cai & \multicolumn{2}{|c|}{ Permanece no mesmo nível } \\
\hline Inflação (IPCA) & $5,91 \%$ & & $4,5 \%$ & \\
\hline
\end{tabular}

${ }^{1}$ Posição em 2013; ${ }^{2}$ posição em 2012; ${ }^{3}$ posição em 2009; ${ }^{4}$ posição em dezembro de 2013.

Fonte: elaboração dos autores com base em dados do IBGE, BCB e Ipeadata.

\section{Considerações Finais}

Procurou-se desenhar os cenários macroeconômicos possíveis, em um horizonte de vinte anos, com vistas a subsidiar um estudo mais amplo, voltado para o planejamento do sistema de saúde brasileiro a médio e longo prazos.

Levando-se em conta as limitações que os estudos prospectivos sempre envolvem, foram apresentadas, desde logo, as dificuldades de ordem analítica e metodológica que necessariamente se colocam para a construção de cenários. 
Tais dificuldades são acrescidas, na atual fase de desenvolvimento do capitalismo brasileiro, pela ocorrência de uma crise internacional, extensa e profunda, cujos desdobramentos ainda não permitem ver o seu fim. Com isso, uma combinação de fatores externos e internos gera instabilidade, que resulta tanto da dinâmica contraditória do desenvolvimento capitalista quanto da incerteza com que os detentores da riqueza, dentro e fora do país (responsáveis, em última instância, pelas decisões de investimento) - incerteza essa que tolda o horizonte com tintas sombrias - olham para o futuro.

Entretanto, como o estudo procurou explorar, o Brasil dispõe de um conjunto de fatores que podem favorecer o enfrentamento da turbulência externa e encontrar caminhos para que o cenário virtuoso se confirme. Tais fatores envolvem elementos de ordem concreta - da transição demográfica à plataforma pré-sal - e de ordem institucional - em especial o sistema de bancos públicos de que o país dispõe. E envolvem também fatores de ordem subjetiva, manifestos na inflexão que a política macroeconômica parece estar experimentando.

Em função de seu impacto macroeconômico sobre a renda, o emprego, o produto nacional e o gasto público, o setor Saúde é inequivocamente estratégico e precisa estar inserido numa política de desenvolvimento. Há amplo espaço para uma agenda de pesquisa que articule a análise macroeconômica às políticas públicas na área da saúde. Em particular, alguma luz precisa ser direcionada aos mecanismos de financiamento ao setor privado que o Estado possui para estimular ações no campo do desenvolvimento industrial e da inovação tecnológica, com alto potencial de impacto positivo sobre a competitividade da indústria nacional e a garantia de oferta de insumos, medicamentos e equipamentos de saúde, democratizando o acesso da população aos bens e serviços necessários à sua sobrevivência saudável e digna.

\section{Referências}

BRASIL. Ministério do Desenvolvimento, Indústria e Comércio Exterior. Balanço executivo do Plano Brasil Maior, 2012. Disponível em: <www.brasilmaior.mdic.gov.br>. Acesso em: 16 abr. 2014.

CARNEIRO, R. Desenvolvimento brasileiro pós-crise financeira: oportunidades e riscos. Texto preparado para o $7^{\circ}$ Fórum de Economia da FGV-SP, 2010. Disponível em: <www.centrocelsofurtado.com.br/arquivos/ image/201108311439510.CARNEIRO1.pdf>. Acesso em: 5 abr. 2014.

GENTIL, D. \& SANTOS, C. A CF/88 e as finanças públicas brasileiras. In: CARDOSO, J. C. (Org.). A Constituição Brasileira de 1988 Revisitada: recuperação histórica e desafios atuais das políticas públicas nas áreas econômica e social. v. 1. Brasília: Ipea, 2009.

INSTITUTO BRASILEIRO DE GEOGRAFIA E ESTATÍSTICA (IBGE). Pesquisa de Orçamentos Familiares 2008-2009: perfil das despesas no Brasil - indicadores selecionados. Rio de Janeiro: IBGE, 2012. Disponível em: <http:// biblioteca.ibge.gov.br/visualizacao/livros/liv61273.pdf>. Acesso em: maio 2014.

INTERNATIONAL MONETARY FUND (IMF). World economic outlook, abr.2014. Disponível em: <www.imf. org >. Acesso em: 15 maio 2014.

INSTITUTO DE PESQUISA ECONÔMICA APLICADA (IPEA). O Brasil na Virada do Milênio: trajetória do crescimento e desafios do desenvolvimento. Brasília: Ipea, 1997.

INSTITUTO DE PESQUISA ECONÔMICA APLICADA (IPEA). Macroeconomia para o Desenvolvimento. Brasília, Rio de Janeiro: Ipea, 2010. (Projeto Perspectivas do Desenvolvimento Brasileiro, livro 4). 
MARSHALL, A. Princípios de Economia. São Paulo: Nova Cultural, 1985.

MINISTÉRIO DA SAÚDE (MS) \& ORGANIZAÇÃO PAN-AMERICANA DA SAÚDE (OPAS). Estratégias para Disseminação da Informação em Economia da Saúde no SUS. Brasília: Ministério da Saúde, 2015. (Série Ecos, Economia da Saúde para Gestão do SUS, eixo 1, v. 2).

SERRANO, F. \& SUMMA, R. Política macroeconômica, crescimento e distribuição de renda na economia brasileira dos anos 2000. Observatório da Economia Global, mar. 2011. (Textos avulsos n. 6).

SIMONSEN, M. H. Brasil 2002. Rio de Janeiro: Apec, 1972.

SOUZA, P. H. G. F. \& OSÓRIO, R. G. O perfil da pobreza no Brasil e suas mudanças entre 2003 e 2011. In: NERI, M. \& CAMPELLO, T. (Orgs.). Programa Bolsa Família: uma década de inclusão e cidadania. Brasília: Ipea, 2013.

TEIXEIRA, A. \& WERNECK VIANNA, S. T. Cenários macroeconômicos no horizonte 2022/2030. In: GADELHA, P.; CARVALHO, J. N. \& PEREIRA, T. R. A Saúde no Brasil em 2030: diretrizes para a prospecção estratégica do sistema de saúde brasileiro. Rio de Janeiro: Fundação Oswaldo Cruz, Ipea, Ministério da Saúde, Secretaria de Assuntos Estratégicos da Presidência da República, 2013.

WORLD HEALTH ORGANIZATION (WHO). Global Health Observatory Data Repository. Disponível em: <apps.who.int/gho/data>. Acesso em: 15 maio 2014. 



\title{
ALTERNATIVAS PARA O FINANCIAMENTO DA SAÚDE PELA UNIÃO: ESPAÇO FISCAL E OPORTUNIDADES PARA AS PRÓXIMAS DUAS DÉCADAS'
}

\author{
Sulamis Dain \\ Kleber Pacheco de Castro
}

A busca de suficiência e estabilidade dos recursos para o Sistema Único de Saúde (SUS) é um tema atual que requer ampla discussão para que se encontrem soluções a fim de garantir o direito constitucional à saúde e a apropriação do espaço fiscal, criado pelos sucessivos aumentos de arrecadação, para o fortalecimento das ações e serviços públicos de saúde (ASPS) nos três níveis de governo.

Apesar da instituição do Orçamento da Seguridade Social (OSS) em 1988, vinculando impostos e contribuições sobre a folha de salários, lucro e faturamento à saúde, previdência e assistência social, nunca foi possível contar com recursos adequados à expansão esperada para o SUS, nos campos do gasto corrente e do investimento do governo federal e dos governos subnacionais, em meio a amplo processo de descentralização de encargos.

Em vista desse subfinanciamento, foram tentadas ações paliativas como a criação da Contribuição Provisória sobre a Movimentação Financeira (CPMF) pela lei n. 9.311/1996, com vigência por uma década a partir de 1997. Tais ações nunca se legitimaram no Congresso, desembocando no veto à prorrogação da CPMF em 2007. Em 2000, foi aprovada a emenda constitucional (EC) n. 29, e a vinculação dos gastos federais de saúde às fontes de financiamento da seguridade social foi substituída pelo atrelamento do crescimento do orçamento federal da saúde à variação nominal do Produto Interno Bruto (PIB).

Dado que a insuficiência crônica de recursos subsistiu, em que pese a existência de espaço fiscal ao longo da década de 2000, o tema do financiamento da saúde continua sendo foco de intenso debate. Devido à clara importância do tema, diversas propostas de alteração da vinculação constitucional de receitas aos gastos em ASPS têm sido apresentadas pela classe política e pelos movimentos sociais, e também pelo meio acadêmico. ${ }^{2}$

\footnotetext{
${ }^{1}$ Elaborado com informações disponíveis até 4 de maio de 2014. Convém informar que a chamada PEC do Orçamento Impositivo foi aprovada e promulgada em 17 de março de 2015, convertendo-se em emenda constitucional (EC) n. 86. Esta informação foi atualizada no texto com o intuito de não causar confusão ou estranhamento ao leitor. As estatísticas utilizadas nas simulações, entretanto, não foram modificadas após a vigência da EC n. 86, mantendo-se assim o aviso de que o capítulo foi elaborado com informações disponíveis até 4 de maio de 2014.

2 Entre outras propostas, podem-se citar: PLC 01/2003, PEC 22A/2000, emenda Lucena à PEC 22A/2000, Saúde +10, Dain (2007), Piola e colaboradores (2013).
} 
Com o fim da CPMF ao final de 2007, a sensação de que seria necessária a revisão nos critérios de gastos com saúde no âmbito do governo federal acelerou o debate, que até hoje está na agenda do Congresso Nacional. A vinculação de receita, a criação de tributos e, mais recentemente, a utilização de compensações financeiras por exploração de recursos naturais têm sido alternativas apresentadas para reforçar o caixa da área da saúde, sem, entretanto, repensar-se a questão do ponto de vista estrutural.

Além disso, existem indicações contraditórias sobre o financiamento da área, como demonstrado pela desoneração tributária em curso, que tem atuado para reduzir a capacidade de gasto e que tomou grande proporção nos últimos anos.

As propostas de reforma tributária, por influírem diretamente nas vinculações constitucionais da seguridade social e na alocação interfederativa de receita, também merecem atenção por parte dos interessados no financiamento da saúde.

Todos esses aspectos, sejam proposições que estão em análise no Congresso ou que já foram instituídas, serão analisados brevemente nas seções a seguir com o intuito de elucidar seus impactos no orçamento da saúde, visando a antecipar as rotas mais prováveis de financiamento do SUS para as próximas décadas.

\section{Simulação das Propostas de Vinculação de Receita e da EC n. 29}

A longa espera pela regulamentação da EC n. $29,{ }^{3}$ que só se efetivou em 2012, proporcionou dois efeitos claros no financiamento público da saúde no Brasil: até 2011 o governo federal gastou menos do que deveria em ASPS, como comprova a Tabela 1; e os governos subnacionais passaram a ter uma participação cada vez maior na composição desse gasto.

Nota-se que, em quase todos os anos de 2000 a 2013, o governo central executou despesas com ASPS em patamar inferior ao que efetivamente deveria ter sido efetuado, de acordo com os critérios da EC n. 29, que determina que a variação do gasto com ASPS de um determinado ano deve ser maior ou igual à variação nominal do PIB do ano anterior.

Apenas em 2000 e 2004 o gasto efetivo com ASPS superou o mínimo regulamentado. Mesmo com a regulamentação da EC n. 29 em 2012, o cenário se manteve, e foi até mesmo intensificado, haja vista que a União passou a executar cada vez menos despesas com relação ao mínimo necessário. De 2000 até o fim de 2013, a saúde deixou de receber $\mathrm{R} \$$ 8,3 bilhões em recursos, apenas utilizando o critério da EC n. $29 .{ }^{4}$

\footnotetext{
${ }^{3}$ Disponível em: <www.planalto.gov.br/ccivil_03/constituicao/Emendas/Emc/emc29.htm>.

${ }^{4} \mathrm{O}$ resultado chama ainda mais atenção se for levado em conta que a União utiliza o conceito de despesa empenhada para apuração de limite de gastos com ASPS. Como a despesa é empenhada, não há garantia de que ela foi efetivamente paga. Usualmente uma parte importante do total empenhado não é paga, sendo inscrita em restos a pagar.
} 
Tabela 1 - Simulação de gastos com ASPS na EC n. 29 sem a inclusão da Contribuição Social para a Saúde, em R\$ milhões correntes - 1999-2013

\begin{tabular}{|r|c|c|c|c|r|r|}
\hline Ano & $\begin{array}{c}\text { Gastos efetivos } \\
\text { com ASPS }\end{array}$ & PIB nominal & $\begin{array}{c}\text { Var. nominal PIB } \\
\text { do ano anterior }\end{array}$ & $\begin{array}{c}\text { Gasto segundo a } \\
\text { EC n. } 29(\Delta \text { PIB })\end{array}$ & $\begin{array}{c}\text { Diferença para } \\
\text { gasto efetivo }\end{array}$ & $\begin{array}{c}\text { Diferença } \\
\text { acumulada }\end{array}$ \\
\hline 1999 & 18.353 & 1.065 .000 & & 18.353 & 0 & 0 \\
\hline 2000 & 20.351 & 1.179 .482 & $5,00 \%$ & 19.271 & 1.081 & 1.081 \\
\hline 2001 & 22.474 & 1.302 .136 & $10,75 \%$ & 22.539 & -65 & 1.016 \\
\hline 2002 & 24.737 & 1.477 .822 & $10,40 \%$ & 24.883 & -146 & 870 \\
\hline 2003 & 27.181 & 1.699 .948 & $13,49 \%$ & 28.240 & -1.059 & -190 \\
\hline 2004 & 32.703 & 1.941 .498 & $15,03 \%$ & 32.485 & 219 & -176 \\
\hline 2005 & 37.146 & 2.147 .239 & $14,21 \%$ & 37.350 & -205 & -734 \\
\hline 2006 & 40.750 & 2.369 .484 & $10,60 \%$ & 41.308 & -558 & -2.014 \\
\hline 2007 & 44.303 & 2.661 .344 & $10,35 \%$ & 45.584 & -1.280 & -4.543 \\
\hline 2009 & 48.670 & 3.032 .203 & $12,32 \%$ & 51.199 & -2.529 & -4.606 \\
\hline 2010 & 58.270 & 3.239 .404 & $13,94 \%$ & 58.333 & -63 & -4.960 \\
\hline 2012 & 61.965 & 3.770 .085 & $6,83 \%$ & 62.319 & -354 & -5.132 \\
\hline
\end{tabular}

Fonte: elaboração dos autores com base em IBGE (2014) e STN (2014).

O cenário de defasagem nos gastos em saúde do governo federal fica pior com a alteração dos critérios que determinam o mínimo a ser despendido no setor. A proposta contida no projeto de lei complementar (PLC) 01/2003, ${ }^{5}$ que vincula 10\% da Receita Corrente Bruta (RCB) da União em gastos com ASPS resultaria em uma diferença acumulada (de 2000 a 2013) de pouco mais de R\$ 277 bilhões. A Tabela 2 apresenta essa simulação.

Nota-se que a diferença entre o gasto segundo o PLC 01/2003 e o gasto efetivo aumenta progressivamente, ano após ano, de 2000 a 2013. Se, no primeiro ano da série, essa diferença era de $\mathrm{R} \$$ 4,9 bilhões, em 2013 ela ficou em $\mathrm{R} \$ 36,6$ bilhões. O fato de o gasto vinculado à receita ter uma evolução muito mais intensa do que o gasto vinculado ao Produto Interno Bruto (PIB) mostra de outra forma um fato amplamente sabido pelos brasileiros: a carga tributária cresceu. Dito de outra maneira, a arrecadação apresentou maior dinamismo que a atividade econômica.

Essa simples constatação já nos permite questionar o critério da EC n. 29 e reforçar a necessidade de se adotar um critério de vinculação, a fim de indexar o orçamento do Ministério da Saúde à arrecadação tributária federal.

\footnotetext{
${ }^{5}$ Disponível em: <www.camara.gov.br/proposicoesWeb/fichadetramitacao?idProposicao=104342>.
} 
Tabela 2 - Simulação de gastos com ASPS na PLP 01/2003 sem a inclusão da Contribuição Social para a Saúde, em R\$ milhões correntes - 1999-2013

\begin{tabular}{|l|c|c|c|c|c|}
\hline Ano & $\begin{array}{c}\text { Gastos efetivos } \\
\text { com ASPS }\end{array}$ & RCB da União & $\begin{array}{c}\text { Gasto segundo a } \\
\text { PLP 01/2003 } \\
(10 \% \text { da RCB })\end{array}$ & $\begin{array}{c}\text { Diferença para } \\
\text { gasto efetivo }\end{array}$ & $\begin{array}{c}\text { Diferença } \\
\text { acumulada }\end{array}$ \\
\hline 1999 & 18.353 & 0 & 0 & 0 & 0 \\
\hline 2000 & 20.351 & 252.519 & 25.252 & -4.900 & -4.900 \\
\hline 2001 & 22.474 & 289.411 & 28.941 & -6.467 & -11.367 \\
\hline 2002 & 24.737 & 343.075 & 34.307 & -9.571 & -20.938 \\
\hline 2003 & 27.181 & 384.447 & 38.445 & -11.264 & -32.202 \\
\hline 2004 & 32.703 & 450.590 & 45.059 & -12.356 & -44.557 \\
\hline 2005 & 37.146 & 527.325 & 52.732 & -15.587 & -60.144 \\
\hline 2006 & 40.750 & 584.067 & 58.407 & -17.657 & -77.800 \\
\hline 2007 & 44.303 & 658.884 & 65.888 & -21.585 & -99.385 \\
\hline 2009 & 48.670 & 754.736 & 75.474 & -26.803 & -126.189 \\
\hline 2010 & 58.270 & 775.407 & 77.541 & -19.270 & -145.459 \\
\hline 2011 & 72.357 & 1.029 .613 & 102.961 & -27.049 & -172.508 \\
\hline 2012 & 78.211 & 1.134 .717 & 113.472 & -30.605 & -203.112 \\
\hline 2013 & 83.053 & 1.219 .646 & 121.965 & -35.261 & -238.373 \\
\hline
\end{tabular}

Fonte: elaboração dos autores com base em IBGE (2014) e STN (2014).

No mês de março de 2015, o Congresso Nacional aprovou a chamada PEC do Orçamento Impositivo (PEC 22A/2000), ${ }^{6}$ convertida na EC n. 86. ${ }^{7}$ Essa emenda determina que $15 \%$ da Receita Corrente Líquida (RCL) da União ${ }^{8}$ devem ser utilizados em ASPS, substituindo o atual critério dado pela EC n. 29. Uma simulação, nos mesmos moldes da anterior, mostra que se tal critério tivesse sido aplicado desde 2000, no final de 2013 a saúde teria recebido R 130 bilhões a mais em recursos, como pode ser verificado na Tabela 3.

\footnotetext{
${ }^{6}$ Disponível em: <www.senado.gov.br/atividade/materia/detalhes.asp?p_cod_mate $=114143>$. Acesso em: 11 jan. 2014.

${ }^{7}$ Disponível em: <www.planalto.gov.br/ccivil_03/Constituicao/Emendas/Emc/emc86.htm>. Acesso em: 12 dez. 2015.

8 O percentual de 15\% estabelecido pela EC n. 86 (artigo $2^{\circ}$ ) será alcançado de forma gradual, sendo 13,2\% em 2016; 13,7\% em 2017; 14,1\% em 2018; 14,5\% em 2019 e apenas em 2020 será aplicado o percentual de 15\% da RCL em ASPS de forma plena.
} 
Tabela 3 - Simulação de gastos com ASPS na PEC Orçamento Impositivo sem a inclusão da Contribuição Social para a Saúde, em R\$ milhões correntes - 1999-2013

\begin{tabular}{|c|c|c|c|c|c|}
\hline Ano & $\begin{array}{l}\text { Gastos efetivos } \\
\text { com ASPS }\end{array}$ & RCL da União & $\begin{array}{l}\text { Gasto segundo a } \\
\text { PEC Orçamento } \\
\text { Impositivo } \\
\text { (15\% da RCL) }\end{array}$ & $\begin{array}{l}\text { Diferença para } \\
\text { gasto efetivo }\end{array}$ & $\begin{array}{c}\text { Diferença } \\
\text { acumulada }\end{array}$ \\
\hline 1999 & 18.353 & 0 & 0 & 0 & 0 \\
\hline 2000 & 20.351 & 145.111 & 21.767 & -1.415 & -1.415 \\
\hline 2001 & 22.474 & 167.739 & 25.161 & -2.687 & -4.102 \\
\hline 2002 & 24.737 & 201.927 & 30.289 & -5.552 & -9.654 \\
\hline 2003 & 27.181 & 224.920 & 33.738 & -6.557 & -16.211 \\
\hline 2004 & 32.703 & 264.353 & 39.653 & -6.949 & -23.160 \\
\hline 2005 & 37.146 & 303.016 & 45.452 & -8.307 & -31.467 \\
\hline 2006 & 40.750 & 344.731 & 51.710 & -10.960 & -42.427 \\
\hline 2007 & 44.303 & 386.682 & 58.002 & -13.699 & -56.125 \\
\hline 2008 & 48.670 & 428.563 & 64.284 & -15.614 & -71.740 \\
\hline 2009 & 58.270 & 437.199 & 65.580 & -7.310 & -79.049 \\
\hline 2010 & 61.965 & 499.867 & 74.980 & -13.015 & -92.064 \\
\hline 2011 & 72.357 & 558.706 & 83.806 & -11.449 & -103.513 \\
\hline 2012 & 78.211 & 616.933 & 92.540 & -14.329 & -117.843 \\
\hline 2013 & 83.053 & 656.094 & 98.414 & -15.361 & -133.204 \\
\hline
\end{tabular}

Fonte: elaboração dos autores com base em IBGE (2014) e STN (2014).

Para todos os anos desde 2000, o critério dado pela PEC do Orçamento Impositivo superaria o gasto efetivo em ASPS. Mesmo supondo que a União tivesse executado o gasto mínimo determinado pela EC n. 29, ainda assim esse critério apresentaria um gasto acumulado de $\mathrm{R} \$ 125$ bilhões a mais do que o resultante dessa emenda.

Acerca do percentual da RCL, aprovado na EC n. 86, convém alertar que a alíquota de 15\% só será alcançada no ano de 2020, dado que o texto aprovado prevê um crescimento progressivo a partir de 2016. Para o alcance dos 15\% serão computados os recursos das emendas parlamentares e dos royalties do petróleo. A Tabela 4 apresenta uma simulação de impacto no gasto com os percentuais aprovados na PEC para o ano de 2013. 
Tabela 4 - Simulação de gastos com ASPS na EC n. 86 sob diversas alíquotas, em R\$ milhões correntes - 2013

\begin{tabular}{|c|c|c|c|c|}
\hline \multicolumn{5}{|c|}{ Gasto segundo a PEC Orçamento Impositivo } \\
\hline Alíquota & RCL & $\begin{array}{c}\text { Gasto simulado com } \\
\text { ASPS }\end{array}$ & $\begin{array}{c}\text { Gasto efetivo com } \\
\text { ASPS }\end{array}$ & $\begin{array}{c}\text { Diferença para gasto } \\
\text { efetivo }\end{array}$ \\
\hline $13,20 \%$ & $656.094 .217 .900,00$ & $86.604 .436 .762,80$ & $83.053 .256 .000,00$ & $-3.551 .180 .762,80$ \\
\hline $13,70 \%$ & $656.094 .217 .900,00$ & $89.884 .907 .852,30$ & $83.053 .256 .000,00$ & $-6.831 .651 .852,30$ \\
\hline $14,10 \%$ & $656.094 .217 .900,00$ & $92.509 .284 .723,90$ & $83.053 .256 .000,00$ & $-9.456 .028 .723,90$ \\
\hline $14,50 \%$ & $656.094 .217 .900,00$ & $95.133 .661 .595,50$ & $83.053 .256 .000,00$ & $-12.080 .405 .595,50$ \\
\hline $15,00 \%$ & $656.094 .217 .900,00$ & $98.414 .132 .685,00$ & $83.053 .256 .000,00$ & $-15.360 .876 .685,00$ \\
\hline
\end{tabular}

Fonte: elaboração dos autores com base em IBGE (2014) e STN (2014).

Durante o trâmite no Congresso para a aprovação da PEC do Orçamento Impositivo, foi apresentada uma emenda pelo senador Cícero Lucena (PSDB/PB), segunda a qual, o percentual a ser atingido em quatro anos seria de 18\% da RCL, e escalonado da seguinte forma: $15 \%$ no primeiro ano de aplicação da mudança, 16\% no segundo ano, 17\% no terceiro, e $18 \%$ no quarto. ${ }^{9}$ Ou seja, os $15 \%$ que, no texto da EC n. 86 só serão obrigatórios em 2020, teriam vigência a partir do primeiro ano de aplicação da emenda (2016).

Para avaliar o impacto dos percentuais anteriormente apontados (alíquotas da emenda do senador Cícero Lucena), foi feita uma simulação com base nos dados de 2013 (Tabela 5).

Tabela 5 - Simulação de gastos com ASPS pela emenda Lucena na PEC do Orçamento Impositivo sob diversas alíquotas, em $\mathrm{R} \$$ milhões correntes - 2013

\begin{tabular}{|c|c|c|c|c|}
\hline \multicolumn{5}{|c|}{ Gasto segundo a emenda Lucena para a PEC Orçamento Impositivo } \\
\hline Alíquota & RCL & $\begin{array}{c}\text { Gasto simulado com } \\
\text { ASPS }\end{array}$ & Gasto efetivo com ASPS & $\begin{array}{c}\text { Diferença para gasto } \\
\text { efetivo }\end{array}$ \\
\hline $15,00 \%$ & $656.094 .217 .900,00$ & $98.414 .132 .685,00$ & $83.053 .256 .000,00$ & $-15.360 .876 .685,00$ \\
\hline $16,00 \%$ & $656.094 .217 .900,00$ & $104.975 .074 .864,00$ & $83.053 .256 .000,00$ & $-21.921 .818 .864,00$ \\
\hline $17,00 \%$ & $656.094 .217 .900,00$ & $111.536 .017 .043,00$ & 83.053.256.000,00 & $-28.482 .761 .043,00$ \\
\hline $18,00 \%$ & $656.094 .217 .900,00$ & $118.096 .959 .222,00$ & $83.053 .256 .000,00$ & $-35.043 .703 .222,00$ \\
\hline \multicolumn{5}{|c|}{ Gasto segundo a PLP 01/2003 } \\
\hline Alíquota & RCB & $\begin{array}{c}\text { Gasto simulado com } \\
\text { ASPS }\end{array}$ & Gasto efetivo com ASPS & $\begin{array}{c}\text { Diferença para gasto } \\
\text { efetivo }\end{array}$ \\
\hline $10,00 \%$ & $219.645 .809 .020,00$ & $121.964 .580 .902,00$ & $83.053 .256 .000,00$ & $-38.911 .324 .902,00$ \\
\hline \multicolumn{5}{|c|}{ Alíquota necessária sobre a RCL para igualar $10 \%$ da RCB } \\
\hline Alíquota & RCL & $\begin{array}{c}\text { Gasto simulado com } \\
\text { ASPS }\end{array}$ & Gasto efetivo com ASPS & $\begin{array}{c}\text { Diferença para gasto } \\
\text { efetivo }\end{array}$ \\
\hline $19,04 \%$ & $656.094 .217 .900,00$ & $124.904 .384 .615,35$ & 83.053.256.000,00 & $-41.851 .128 .615,35$ \\
\hline
\end{tabular}

Fonte: elaboração dos autores com base em IBGE (2014) e STN (2014).

\footnotetext{
${ }^{9}$ Disponível em: <www12.senado.gov.br/noticias/materias/2013/11/12/aprovada-pec-do-orcamento-impositivoinclui-mais-recursos-para-a-saude > . Acesso em: 11 jan. 2014.
} 
Como se observa, a emenda do senador Lucena traria um volume de recursos significativamente maior à saúde que o texto efetivamente aprovado. Uma alíquota de 18\% sobre a RCL proporcionaria um incremento de mais de $40 \%$ aos gastos com ASPS de 2013, ao passo que, com a alíquota de $15 \%$, esse incremento seria de apenas 18,5\%. A diferença de $3 \%$ entre as duas alíquotas significaria um aumento de quase R $\$ 20$ bilhões ao setor em 2013: pelo texto da PEC a simulação mostra mais R \$ 15,4 bilhões ao orçamento da saúde desse ano, enquanto na emenda do senador Lucena esse aumento seria de $\mathrm{R} \$ 35$ bilhões.

A proposta anterior é a que mais se aproxima da proposta ideal, defendida em campanha nacional pelos movimentos sociais e instituições - Centro Brasileiro de Estudos de Saúde (Cebes) e Associação Brasileira de Saúde Coletiva (Abrasco) -, além de alguns setores do Congresso Nacional, ligados historicamente à Reforma Sanitária que deu origem ao SUS.

Os defensores de um maior volume de gastos para a saúde têm como referência mais importante o PLC 01/2003, que obrigaria a União a destinar 10\% de sua RCB para os gastos com ASPS. Se tal critério fosse utilizado em 2013, o gasto efetivo dessa função seria de aproximadamente R\$ 121,9 bilhões. Se o critério do senador Lucena fosse aplicado (18\% da RCL), o gasto seria de R \$ 118 bilhões, correspondendo a 96,8\% do gasto ideal. Uma simulação inversa - partindo do gasto para deduzir uma alíquota - mostra que o percentual da RCL que corresponderia a 10\% da RCB seria 19,04\% - resultado bem próximo da proposta do citado senador. Essa simulação inversa também é apresentada na Tabela 5.

Ainda há um longo caminho para se alcançar um patamar razoável de gasto público em saúde no país. O gasto total do Brasil é estimado em 9\% do PIB (WHO, 2013), o que não é pouco, em termos internacionais. Entretanto, a participação pública é baixa para um sistema universal e de atendimento integral (4,23\% do PIB, 47\% do gasto total), enquanto a participação do gasto privado é muito alta (4,77\% do PIB, 53\% do gasto total). O gasto privado direto (out of pocket) representa 30,6\% do total de gastos, o que é extremamente elevado para um sistema universal.

Conforme mostrado no Gráfico 1, a estrutura de gastos em saúde do Brasil pode ser confrontada com a de vários países, sobretudo com os que possuem sistemas públicos universais, como o Canadá, a Espanha e o Reino Unido, evidenciando as distorções de nosso sistema, mais próximo ao sistema norte-americano, dominantemente de gasto privado e com gasto do setor público restrito a populações de maior fragilidade econômica e social. 
Gráfico 1 - Participação de fontes públicas e privadas na saúde - 2009

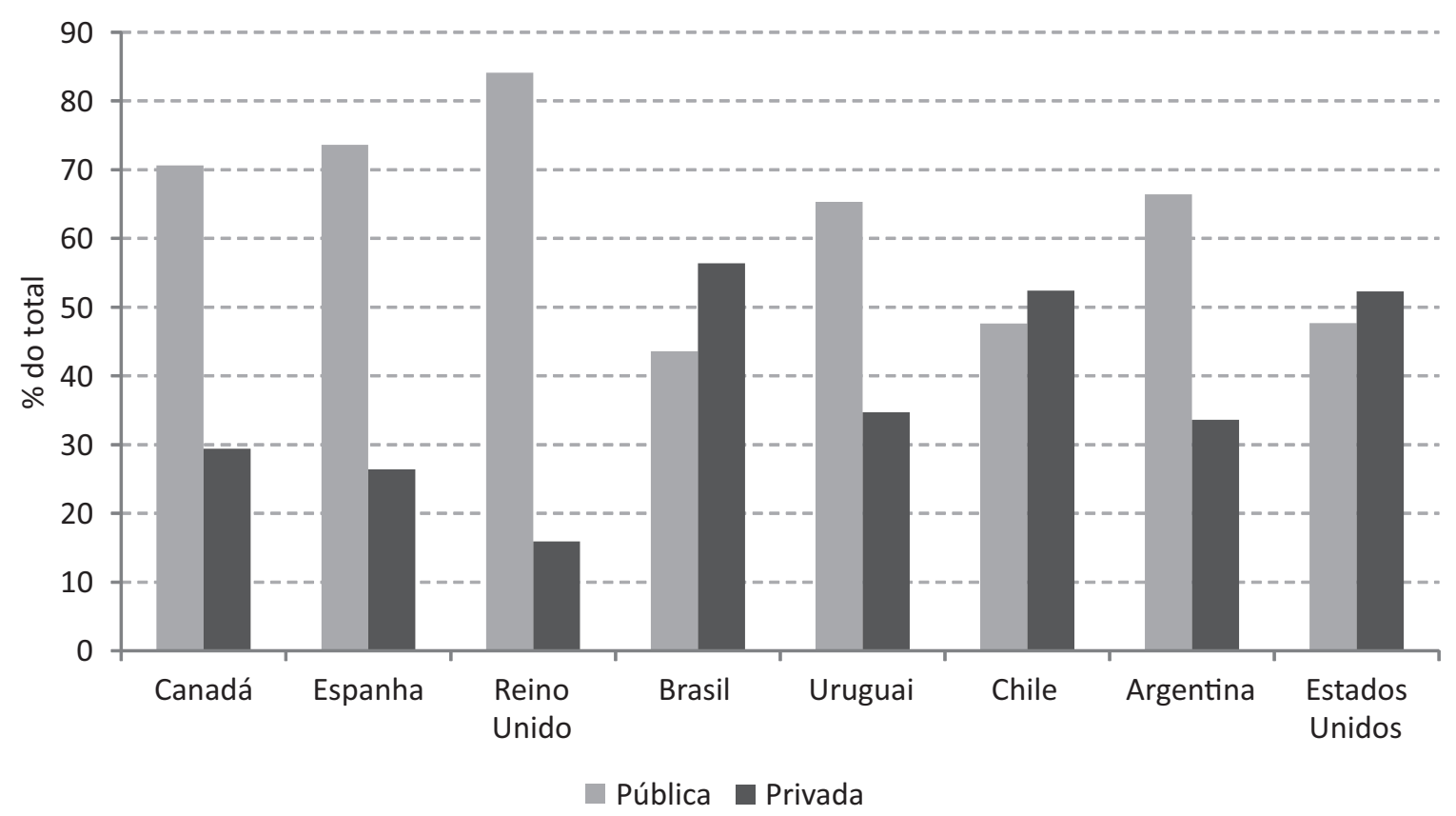

Fonte: Piola, 2014: 6.

\section{Relações Federativas em Saúde}

O crescimento da participação dos governos subnacionais na saúde pública no Brasil pode ser atribuído corretamente à orientação descentralizadora da Constituição de 1988, que estabeleceu novas responsabilidades para estados e municípios.

A descentralização do sistema de saúde esteve vinculada a um processo mais amplo de transição política e de reconfiguração da Federação brasileira, iniciado pelos movimentos democráticos da década de 1980 e moldado, posteriormente, pelos programas de ajuste macroeconômico. Esse novo acordo federativo deu mais autonomia aos municípios, mas também expandiu os recursos e controles do nível federal. A saúde foi o único setor que implementou uma descentralização radical, com importante financiamento e ações regulatórias do governo federal. (Paim et al., 2011: 19)

Entretanto, a descentralização não deve ser atribuída exclusivamente ao fortalecimento do federalismo brasileiro. A conjuntura fiscal pela qual o país passou nas décadas de 1990 e 2000, bem como a primazia do ajuste fiscal aliada ao baixo interesse político do governo central em promover as melhorias reivindicadas pelo Ministério da Saúde no sistema de financiamento do setor, já assinaladas, foram responsáveis pelo movimento observado no Gráfico 2. 
Gráfico 2 - Participação no total das despesas com ASPS por esfera de governo - 2000-2012

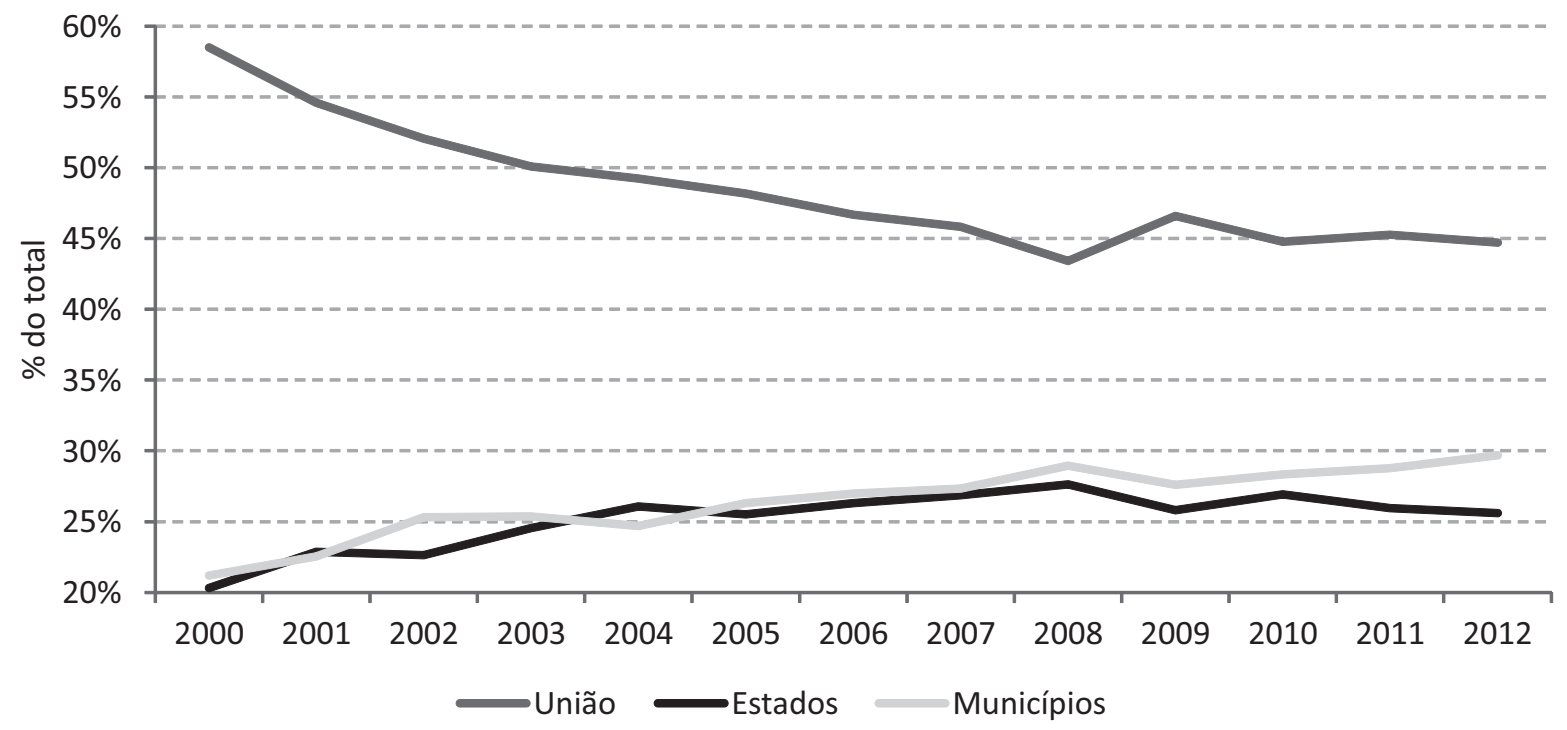

Fonte: Brasil, 2014a.

Se no início da década de 2000 a União respondia por quase $60 \%$ dos gastos com ASPS, em 2012 essa participação ficou bem próxima de $45 \%$ do total. Ou seja, atualmente, estados e municípios, juntos, já respondem pela maior parte dos gastos com ASPS. Os municípios apresentaram o aumento mais expressivo de participação no gasto no período em análise (de 21,2\%) e respondem, em 2000, por pouco menos de 30\% do total em 2012.

Do ponto de vista da equidade no acesso a serviços, o enfraquecimento da participação federal parece preocupante, pois nela se deposita a possibilidade de reorientar investimentos e reforçar gastos destinados a promover o maior equilíbrio territorial na prestação e qualificação ASPS. Persiste a necessidade de liderar, por meio do poder financeiro da União, um processo ordenado de descentralização de encargos, na lógica própria do SUS, contrariada, ano após ano, pela frustração do crescimento do orçamento federal da saúde.

\section{Contribuição Social para Saúde}

Os dados apresentadas na seção anterior não consideram a possibilidade de aprovação de uma contribuição sobre a movimentação financeira exclusiva da saúde, a Contribuição Social para a Saúde (CSS), que viria a repor parcialmente a receita da extinta CPMF, trazendo também modificações para atenuar o impacto da incidência sobre os contribuintes de menor renda (Dain \& Castro, 2008; Viol et al., 2001). Para todas as simulações realizadas, poder-se-iam adicionar os recursos estimados da CSS, aumentando ainda mais a defasagem do gasto da União com saúde pública relativamente ao potencial de arrecadação vinculado à saúde. 
À época do lançamento da proposta da CSS, em 2008, estimava-se uma receita de R\$10 bilhões/ ano. De acordo com o relatório da comissão especial destinada a discutir o financiamento da saúde pública (Brasil, 2013c), a CSS teria uma arrecadação projetada de R\$ 38 bilhões em 2018. Utilizando uma progressão linear simples a partir dessas duas estimativas (2008 e 2018), a receita de CSS para os anos intermediários foi calculada. Em 2013 a contribuição chegaria a R 24 bilhões, sendo apenas 80\% (R\$19,2 bilhões) utilizáveis, se levarmos em conta o efeito da Desvinculação das Receitas da União (DRU). O Gráfico 3 mostra a evolução estimada da CSS de 2008 a 2018, bem como o efeito da DRU sobre a receita.

Gráfico 3 - Estimativa de arrecadação da Contribuição Social para a Saúde - 2008-2018

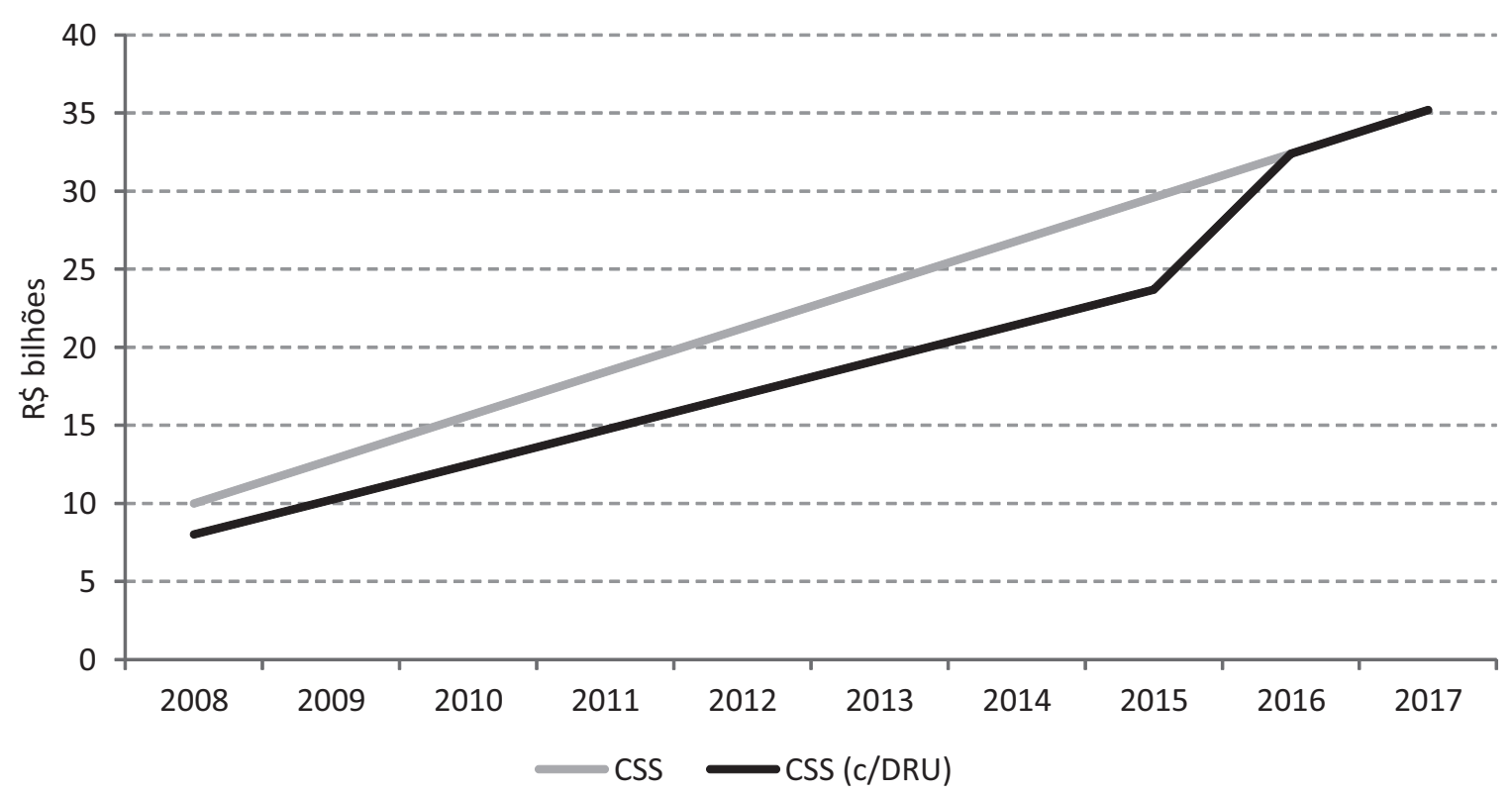

Fonte: elaboração própria com base em Brasil, 2013c.

A partir de 2016 a receita da CSS seria integral, visto que a DRU está prevista para vigorar até o final de 2015. ${ }^{10}$ Dado que é possível que a DRU venha a ser prorrogada mais uma vez, haveria diminuição do potencial de recursos a ser destinado à saúde.

A todas as simulações até aqui apresentadas, foi acrescida a projeção da CSS, considerando-se um repasse de $80 \%$ do tributo - ou seja, não foi considerada a possibilidade de uma eventual destinação parcial do referido tributo a outras finalidades de gasto, como ocorreu com a CPMF. As tabelas 20 a 24, com esses resultados, estão dispostas no Anexo.

Apesar do considerável fortalecimento do orçamento da saúde que a CSS poderia proporcionar mais uma vez, considerando que todos os seus recursos disponíveis fossem utilizados exclusivamente no seu objetivo principal, isto é, financiamento da saúde -, pesa contra o tributo o desgaste do sistema tributário e da carga tributária perante a sociedade.

\footnotetext{
${ }^{10}$ Atualmente a DRU não está vigendo, tendo se encerrado em 31 de dezembro de 2015. Contudo, há uma PEC (78/2015) tramitando no Congresso que prevê a renovação da DRU até 31 de dezembro de 2023.
} 
O Fundo Monetário Internacional (2013) aponta o Brasil como o país que faz o maior esforço tributário do mundo, utilizando aproximadamente $96 \%$ de sua capacidade de arrecadação. Ou seja, é provável que a criação de um novo tributo esbarre em dificuldades políticas. Nesse caso, a criação de um imposto com recursos vinculados à saúde deveria estar atrelada a um debate mais amplo de reforma tributária.

\section{Reforma Tributária}

A reforma tributária é um tema recorrente nos discursos dos especialistas da área e também surge eventualmente em alguns projetos de lei que tramitam no Congresso Nacional (ainda que, de forma inócua, em sua maioria). Tal assunto é ponto nevrálgico na análise de cenários de financiamento da saúde. Apesar da clara dificuldade política de promover mudanças em uma área que altera a disposição de recursos em diversos níveis (federativo, regional, setorial e social), assumir a possibilidade de reforma do atual sistema pode ser visto como uma atitude pragmática e defensiva pelos interessados no tamanho do orçamento da saúde. Isto é, qualquer tentativa de reformar o sistema tributário deve envolver necessariamente o financiamento da saúde pública, sob pena do setor permanecer subfinanciado.

Parece desnecessário explicar os (bons) motivos que levariam o país a passar por uma reforma tributária atualmente. Porém, é importante destacar que a urgência dessa reforma torna-a iminente. Qualquer projeto de reforma tributária baseado em racionalidade técnica inclui a revisão das contribuições sociais. Assim, necessariamente apontam para a revisão da vinculação de recursos e também dos recursos do orçamento da seguridade social.

A PEC 233/2008, última proposta ampla de reforma tributária oriunda do Executivo federal sobre o tema, estabelecia, de forma implícita, uma mudança da fonte de receita da saúde. De acordo com essa PEC, a criação do Imposto sobre o Valor Adicionado (IVA) federal, consolidando a receita da Contribuição para o Financiamento da Seguridade Social (Cofins), do Programa de Integração Social (PIS), do Programa de Formação do Patrimônio do Servidor Público (Pasep), da Contribuição de Intervenção no Domínio Econômico (Cide) e do salário-educação, seria acompanhada pela alteração dos fundos de participação de estados e municípios e da seguridade social.

A PEC previa que 38,8\% do IVA, do Imposto de Renda (IR) - a Contribuição sobre o Lucro Líquido (CSLL) passaria a ser incorporada pelo IR - e do Imposto de Produtos Industrializados (IPI) seriam destinados ao financiamento da seguridade social.

A partir das regras de partilha sugeridas no projeto e dos impostos e contribuições que constituem sua base de cálculo, é possível estimar o montante de recursos que financiariam a seguridade social como um todo, sem discriminação entre saúde, assistência social e previdência. Utilizando-se uma estimativa da carga tributária da União para 2013 e considerando-se um crescimento real do PIB de 2,3\% (deflator de 7,44\%) para o mesmo ano, restariam, para a seguridade, cerca de $\mathrm{R} \$ 209,7$ bilhões de reais, ${ }^{11}$ que se comparam desfavoravelmente com os recursos hoje alocados ao OSS,

\footnotetext{
${ }^{11}$ Esse valor já leva em conta a DRU, que desvincula $20 \%$ das receitas da União que têm destinação predeterminada. Portanto, o cálculo para a obtenção desse número seria: $80 \%$ do somatório de $38,8 \%$ do IVA (Cofins + PIS + Pasep + Salário-educação), 38,8\% do IR (IR + CSLL) e 38,8\% do IPI.
} 
excluindo-se a folha de salários que é fonte exclusiva da previdência social - de acordo com as estimativas de arrecadação para 2013, registradas na Tabela 6.

Tabela 6 - Estimativa de arrecadação tributária e de recursos destinados à seguridade social sem a Contribuição Social para a Saúde, de acordo com a PEC 233/2008 - 2013

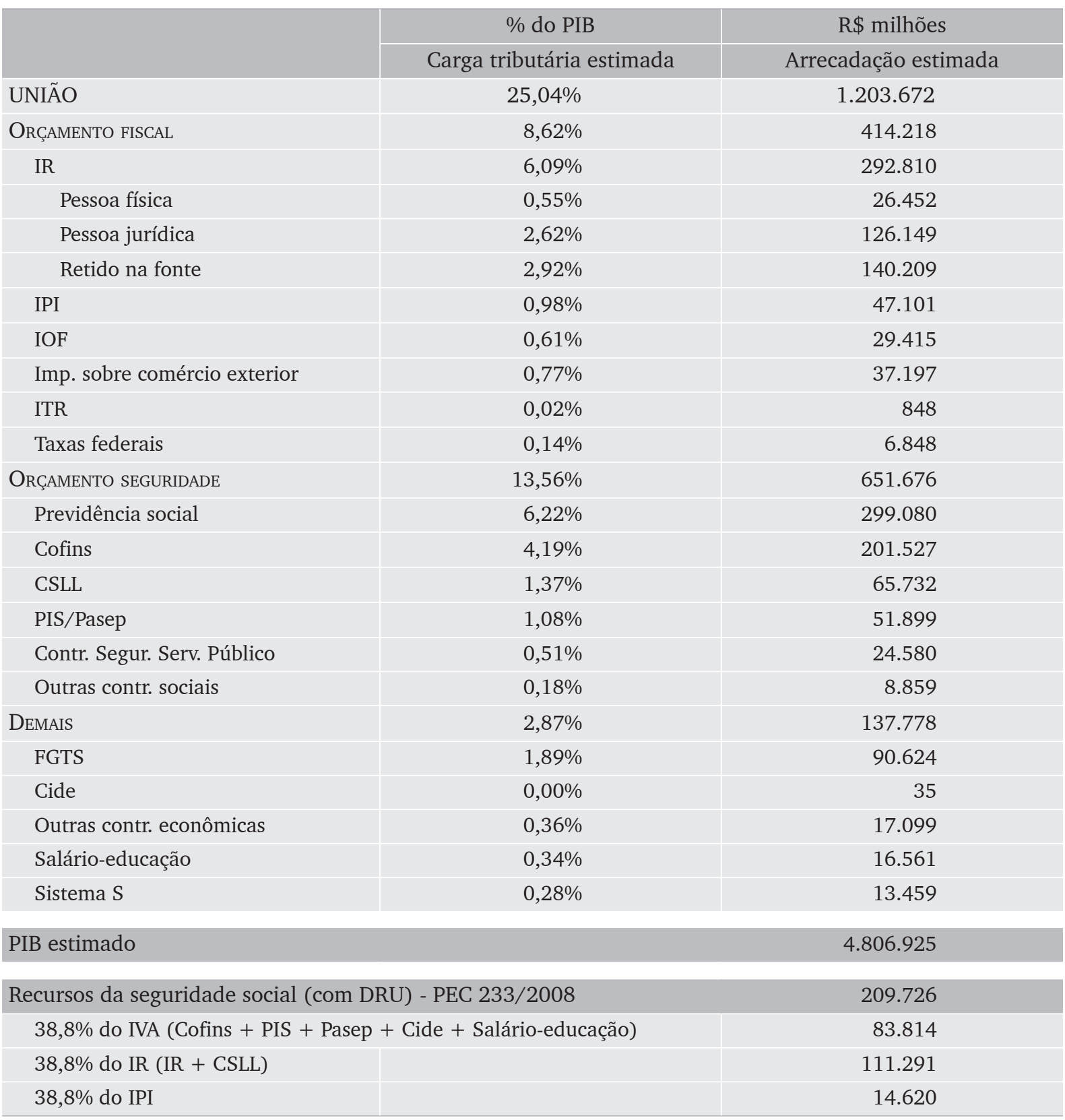

Nota: IOF = Imposto sobre Operações Financeiras; ITR = Imposto sobre a Propriedade Territorial Rural. Fonte: elaboração dos autores com base em IBGE (2014), RFB (2014), Brasil (2014b) e CEF (2014). 
Com efeito, esse total é apenas pouco superior à arrecadação da Cofins, sugerindo maiores dificuldades para financiar as ASPS, em circunstâncias que podem ser facilmente projetadas para o futuro, lembrando que este balão de ensaio de reforma ecoou no debate sobre o financiamento da saúde, tendo merecido os protestos do Ministério da Saúde, além de discussões e publicações organizadas pelo Cebes (Dain, 2009).

Um segundo projeto de reforma tributária foi lançado pelo então senador Francisco Dornelles (PP/RJ). Nesse caso, todas as vinculações passariam a ser financiadas por uma única e abrangente base, o que jogaria as contribuições sociais no perigoso campo da partilha federativa dos fundos de participação de estados e municípios. Segundo o projeto:

A mesma base abrangente dos fundos de participação, formada pela totalidade da arrecadação tributária da União, também será das vinculações para programas, ações e serviços públicos hoje financiados pelas contribuições, tais como: a seguridade social (Cofins e CSLL); o fundo de amparo ao trabalhador (PIS/Pasep); o ensino básico (salário-educação); e os investimentos em infraestrutura (caso das contribuições econômicas para transportes e desenvolvimento tecnológico), dentre outros. Os percentuais para tais destinações específicas serão fixados de forma que não haverá perda de recursos para os programas setoriais com a incorporação das contribuições aos impostos. Será preservada a destinação de recursos para ensino público e para o sistema único de saúde hoje oriunda das receitas de impostos. (Dornelles, 2010: 59-60)

A "base abrangente dos fundos de participação" se refere ao produto total da arrecadação de impostos e contribuições, exceto as de melhoria e as destinadas ao custeio de benefícios previdenciários. Como atualmente a vinculação para despesas em saúde na União não tem essa base de cálculo, seria preciso estimar qual deveria ser o percentual da receita, de impostos e contribuições destinados à saúde, na nova base, para utilizá-lo como parâmetro para exercícios futuros.

No caso de estados e municípios, as regras de vinculação no presente têm mais semelhança com o que é proposto no projeto do ex-senador Dornelles. Porém, há uma significativa diferença: atualmente as alíquotas de $12 \%$ e $15 \%$ da receita de impostos de, respectivamente, estados e municípios são aplicadas depois de deduzidas as parcelas das transferências constitucionais; enquanto no referido projeto, a mesma base abrangente seria adotada para os dois casos, tanto para as transferências como para as vinculações sociais. Isso, sem mencionar que o SUS e os fundos de participação apresentam critérios de partilha radicalmente diversos.

Para estimar a alíquota a ser aplicada sobre a base abrangente de modo a manter o mesmo nível de gastos com saúde, foram utilizados os dados estimados de 2013 de carga tributária e os dados consolidados de gastos efetivos com ASPS. No cenário médio (crescimento real do PIB de 2,3\% e deflator de 7,44\%, em 2013), os gastos com saúde representavam 13,15\% da receita de impostos e contribuições da União (excluídas a receita previdenciária ampla e a receita de contribuições de melhoria). Esse percentual foi tomado como a alíquota a ser aplicada para garantir o financiamento federal da saúde em caso de reforma. A Tabela 7 resume essa estimativa. 
Tabela 7 - Estimativa de arrecadação tributária e de recursos destinados à saúde sem CSS, de acordo com a proposta de Francisco Dornelles - 2013

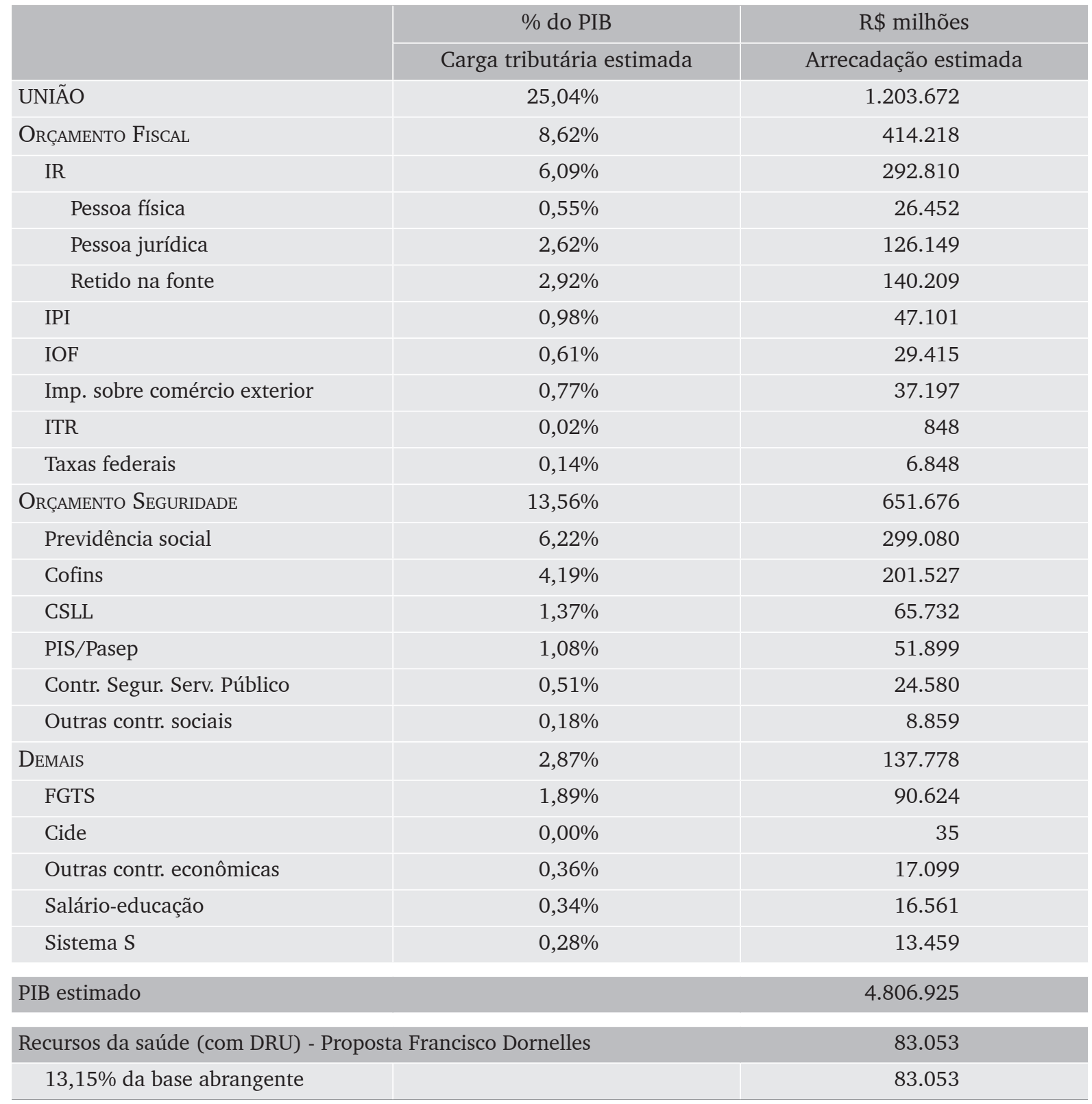

Nota: A base abrangente inclui imposto e contribuições, excluíndo a previdência (conceito amplo) e as contribuições de melhoria.

Fonte: elaboração dos autores com base em IBGE (2014), RFB (2014), Brasil (2014b) e CEF (2014). 
Nota-se que a simulação de gasto para o ano de 2013, no cenário médio, não difere em nada do que foi efetivamente gasto em 2013 ( $\mathrm{R} \$ 33$ bilhões). Isso era esperado, na medida em que o projeto prevê simplesmente a aplicação de uma alíquota que não reduza os recursos de determinada área.

Entretanto, a simples utilização do gasto efetivo em saúde como referência para o cálculo da alíquota não permite dar a real dimensão do potencial da base abrangente como ponto de partida para a vinculação de saúde. As simulações anteriores, baseadas em outras propostas de vinculação, também podem ser aplicadas ao caso da proposta de reforma tributária do ex-senador Dornelles, obtendo-se assim as alíquotas necessárias para se igualar propostas em termos de volume de gastos. A Tabela 8 apresenta resumidamente essa ideia.

Tabela 8 - Alíquotas necessárias sobre a base abrangente para destinação de recursos à saúde de acordo com vários critérios - 2013

\begin{tabular}{|l|c|c|}
\hline & R\$ milhões & Alíquota necessária para igualar \\
\hline Base abrangente (com DRU) & 631.511 & - \\
\hline Gasto efetivo & 83.053 & $13,15 \%$ \\
\hline EC n. 29 & 84.696 & $13,41 \%$ \\
\hline $10 \%$ da RCB & 121.965 & $19,31 \%$ \\
\hline $15 \%$ da RCL & 98.414 & $15,58 \%$ \\
\hline $18 \%$ da RCL & 118.097 & $18,70 \%$ \\
\hline
\end{tabular}

Nota: A base abrangente inclui imposto e contribuições, excluíndo a previdência (conceito amplo) e as contribuições de melhoria.

Fonte: elaboração dos autores com base em IBGE (2014), RFB (2014), Brasil (2014b) e CEF (2014).

Se tomarmos como referência a proposta ideal (10\% da RCB), que proporcionaria quase R\$ 122 bilhões à saúde em 2013, seria necessário prever a aplicação de uma alíquota de aproximadamente 19,3\% sobre a base abrangente da proposta de Dornelles para que ela chegasse ao mesmo patamar da PLP 01/2003. Da mesma forma, para obter um volume de gastos idêntico ao da PEC do Orçamento Impositivo (15\% da RCL) a partir da base abrangente, deveria ser aplicada uma alíquota de 15,58\% sobre essa última. Uma alíquota de 13,4\% (pouco acima dos 13,15\% obtidos a partir do gasto efetivo) seria necessária para que essa reforma tributária mantivesse o volume de despesas proposto pela EC n. 29.

Assim, torna-se essencial o diálogo entre propostas para elevação de recursos para a saúde e projetos de reforma tributária. Isso permitiria cotejar critérios alocativos e projeções de receita para os orçamentos da saúde, levando em conta as alternativas de reforma consideradas no debate e passíveis de implementação no futuro. Sem isso, o espaço fiscal da saúde pode ser significativamente limitado e a hierarquização de ações, presente em seu processo de descentralização, totalmente subvertida. 


\section{Royalties e Outras Compensações do Petróleo}

O franco desenvolvimento da indústria do petróleo no Brasil desde meados da década de 1990 - que proporcionou à Petrobras a liderança mundial da produção e da tecnologia de exploração de petróleo em águas profundas - culminou com a descoberta de grandes reservas de petróleo e gás natural na chamada camada pré-sal.

A comprovação das reservas colocou o Brasil no grupo de países com grande volume da matériaprima. De acordo com dados da British Petroleum (BP), em 2012 o Brasil figurava como o $15^{\circ}$ colocado na classificação de reservas provadas de petróleo, com 15,3 bilhões de barris. Se considerarmos os dados da Agência Nacional do Petróleo (ANP), que levam em conta as reservas dos campos cujos planos de desenvolvimento estão em análise, esse volume passa a 28,5 bilhões de barris, o que faria o Brasil subir no ranking, para a $13^{a}$ colocação, superando Catar e China.

De fato, a descoberta do pré-sal tornou-se um marco, não só na história do setor, como na história do país. Entretanto, o entusiasmo inicial deu lugar a dúvidas, que giravam em torno da viabilidade financeira da produção, da tecnologia a ser empregada, do marco regulatório do setor, da partilha federativa e da destinação social das compensações financeiras e das implicações macroeconômicas.

Tal cenário, ainda nebuloso, é sintetizado por Losekann e Periard (2013):

As reservas do pré-sal constituem a possibilidade de reversão de uma tendência histórica brasileira de importador de petróleo, já que com estas descobertas se prevê um cenário onde o país irá ter petróleo em quantidade suficiente para se tornar um exportador líquido da mercadoria. No entanto, apesar de toda a euforia criada pela descoberta do pré-sal, ainda não se tem com clareza qual o tamanho de seu impacto econômico para o Brasil.

A falta de informações claras e precisas acerca dos principais parâmetros da camada pré-sal contribui para a continuidade das dúvidas. Como assinalado anteriormente, há estimativas diferentes das reservas comprovadas entre a BP (fonte internacional e muito tradicional no setor de petróleo) e a ANP (órgão regulador do setor no Brasil e fonte oficial do governo).

Entretanto, a projeção de produção em um horizonte de médio prazo - fundamental para prever o ingresso de receita no setor público - apresenta divergências menos significativas, ainda que realizada com base em fontes diferentes. O Gráfico 4 mostra duas projeções a partir de dados Empresa de Produção Energética (EPE, 2013) e do International Energy Agency (IEA, 2013).

Como pode ser observado, os cálculos da entidade nacional (EPE) são, novamente, mais otimistas que os da agência internacional. Segundo a EPE, estima-se que em 2035 o país esteja produzindo 6,8 milhões de barris/dia, ao passo que, segundo a agência internacional (IEA), a estimativa gira em torno de 6 milhões de barris/dia. A despeito da diferença absoluta, a tendência das duas projeções é semelhante (as curvas apresentam inclinações próximas), o que indica que deve haver consistência nos cálculos das duas entidades.

Há ainda uma expectativa de que a camada pré-sal passe a ter, cada vez mais, maior participação no total da produção de petróleo no Brasil. Com a estabilidade (e posterior decadência) na exploração 
da camada pós-sal e o aumento da atividade nos poços mais profundos, essa expectativa deve ser de fato verificada. O Gráfico 5 apresenta uma projeção para essa participação.

Gráfico 4 - Estimativa de produção de petróleo. Brasil - 2011-2035

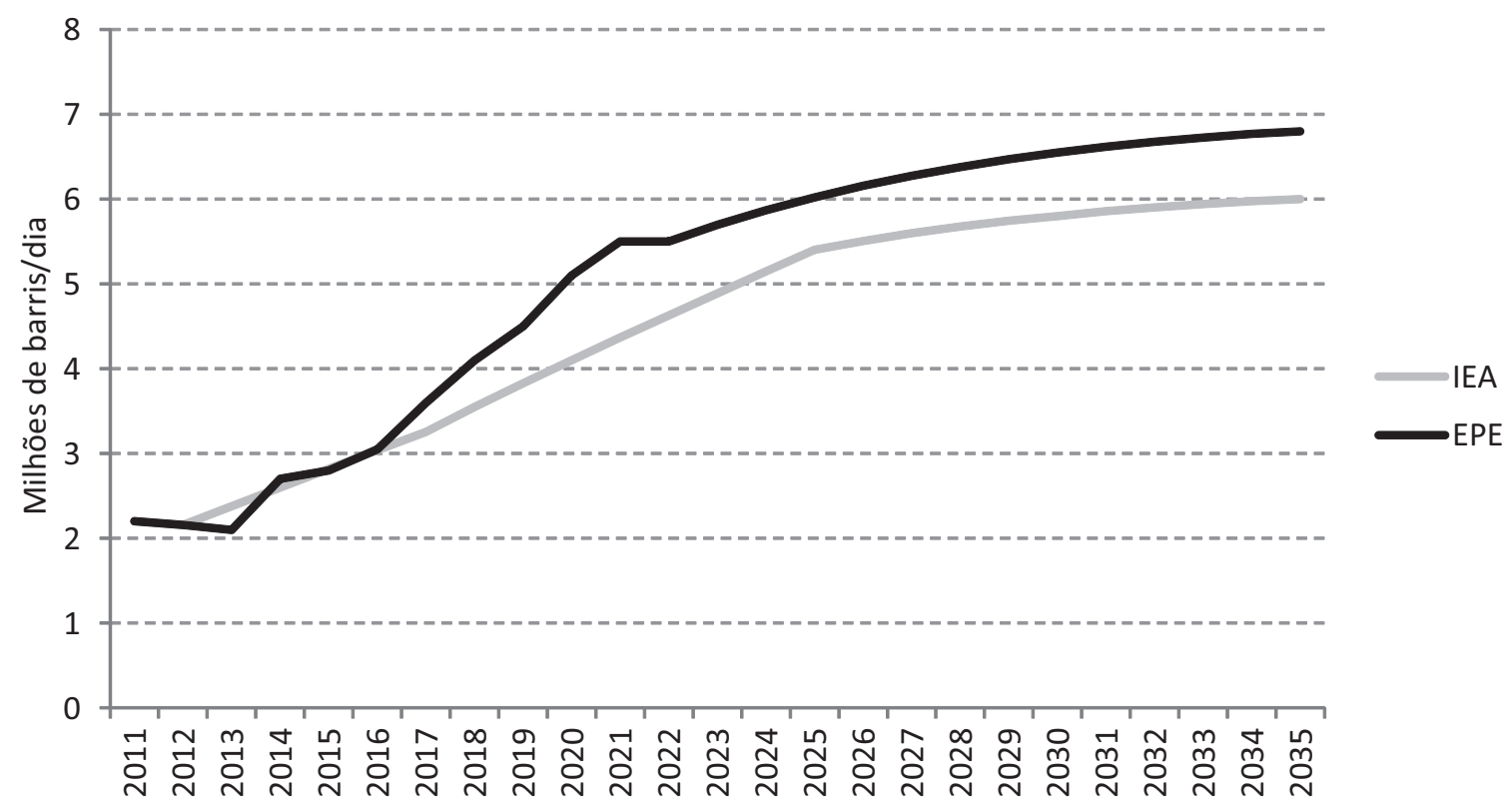

Fonte: elaboração própria com base em EPE (2013) e IEA (2013).

Gráfico 5 - Estimativa de produção de petróleo por área de exploração. Brasil - 2013-2035

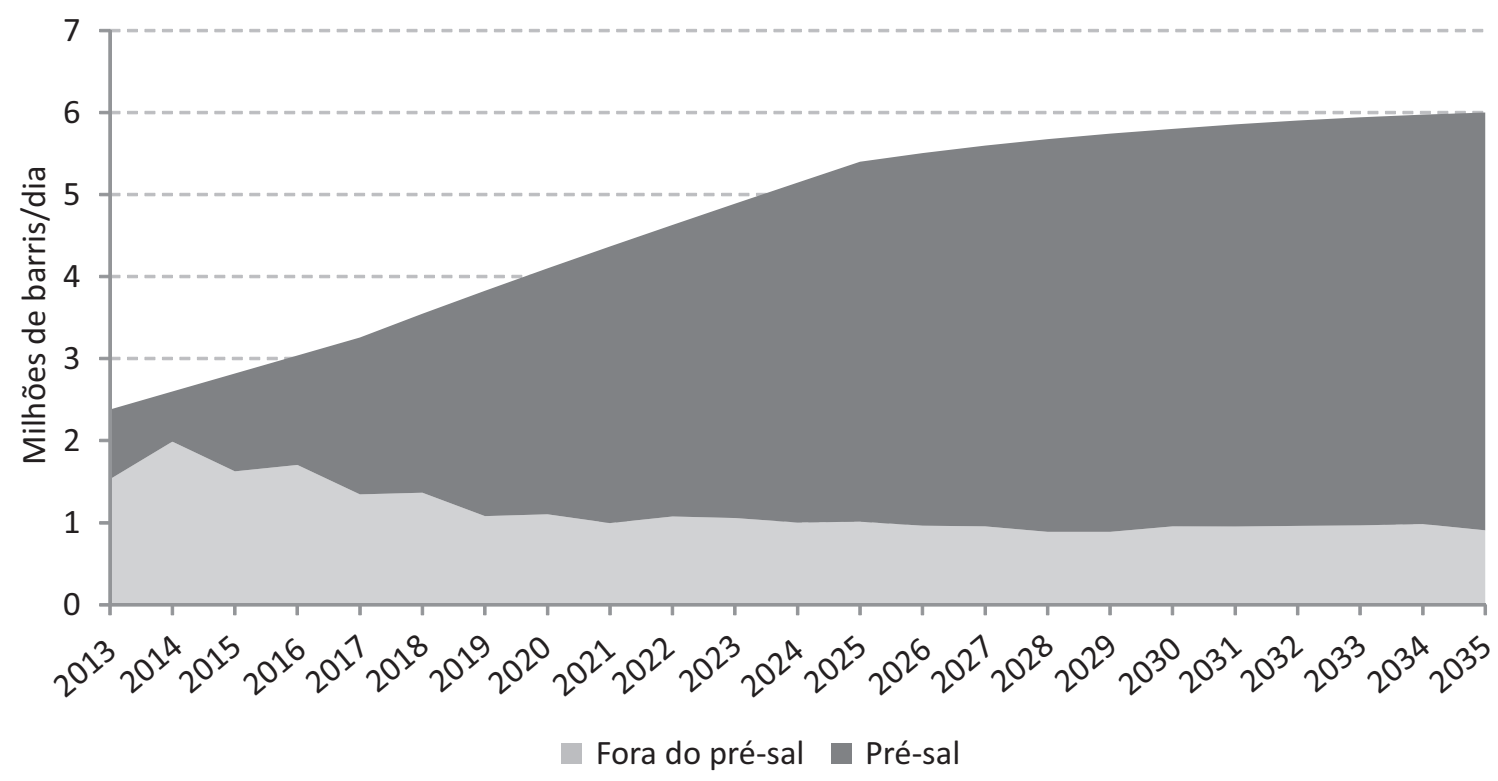

Fonte: elaboração dos autores com base em IEA (2013) e Brasil (2013d). 
Como observado no Gráfico 5, a produção da camada pré-sal teria uma crescente participação na produção total do país, passando de 35,7\% em 2013 para 84,9\% em 2035. Essa simples informação dá uma boa dimensão da importância da descoberta da reserva do pré-sal, não só para o futuro do setor petrolífero mas também para o setor público, que espera auferir boa parte dos rendimentos da exploração de petróleo e gás.

As participações governamentais oriundas da exploração da camada pré-sal foram o ponto de partida para um dos principais debates federativos dos últimos anos. O recebimento de royalties e outras compensações financeiras pela União e por uma pequena parte de governos regionais (usualmente localidades afetadas pelas atividades de exploração), que até então praticamente não era questionado, passou a ser alvo de críticas por parte dos governos regionais menos favorecidos no processo de divisão. A simples expectativa de que o volume de participações governamentais iria aumentar significativamente em um futuro próximo desencadeou um novo processo de guerra fiscal, em que o objetivo não seria atrair a atividade empresarial, como ocorre com a guerra fiscal do Imposto sobre Operações relativas à Circulação de Mercadorias e sobre Prestações de Serviços de Transporte Interestadual e Intermunicipal e de Comunicação (ICMS), mas de tentar auferir o maior volume de recursos possível a partir do que fosse extraído da atividade de exploração de petróleo e gás natural.

Inicialmente a discussão ficou atrelada à questão da partilha desses recursos, tanto no âmbito das esferas de governo, quanto no âmbito regional. Uma das formas de apaziguar os ânimos nesse conflito federativo foi a sugestão do governo federal de destinar 100\% da receita de royalties para a educação.

Tal proposta, modificada para incluir a saúde, foi elaborada no Congresso Nacional que, em meados de 2013, aprovou a lei n. 12.858, sancionada em 9 de setembro de 2013. A lei prevê que os royalties e outras compensações financeiras do petróleo sejam destinados à educação (em uma proporção de $75 \%$ ) e à saúde (em uma proporção de 25\%). Porém, não se trata de todas as participações governamentais obtidas a partir da atividade. Os recursos são especificados pela lei:

I - as receitas dos órgãos da administração direta da União provenientes dos royalties e da participação especial decorrentes de áreas cuja declaração de comercialidade tenha ocorrido a partir de 3 de dezembro de 2012, relativas a contratos celebrados sob os regimes de concessão, de cessão onerosa e de partilha de produção, de que tratam respectivamente as Leis $n^{\text {ss }} 9.478$, de 6 de agosto de 1997, 12.276, de 30 de junho de 2010, e 12.351, de 22 de dezembro de 2010, quando a lavra ocorrer na plataforma continental, no mar territorial ou na zona econômica exclusiva;

II - as receitas dos Estados, do Distrito Federal e dos Municípios provenientes dos royalties e da participação especial, relativas a contratos celebrados a partir de 3 de dezembro de 2012, sob os regimes de concessão, de cessão onerosa e de partilha de produção, de que tratam respectivamente as Leis nos 9.478 , de 6 de agosto de 1997, 12.276, de 30 de junho de 2010, e 12.351, de 22 de dezembro de 2010 , quando a lavra ocorrer na plataforma continental, no mar territorial ou na zona econômica exclusiva;

III - 50\% (cinquenta por cento) dos recursos recebidos pelo Fundo Social de que trata o art. 47 da Lei $\mathrm{n}^{\circ}$ 12.351, de 22 de dezembro de 2010, até que sejam cumpridas as metas estabelecidas no Plano Nacional de Educação; e 
IV - as receitas da União decorrentes de acordos de individualização da produção de que trata o art. 36 da Lei $\mathrm{n}^{\mathrm{o}}$ 12.351, de 22 de dezembro de 2010. (destaque nosso) ${ }^{12}$

Ou seja, observa-se que há restrições na classificação dos recursos que devem ser utilizados para as finalidades sociais previstas na lei. Se o critério de "declaração de comercialidade ocorrido a partir de 3 de dezembro de 2012", aplicado à União, já é restritivo em termos de espaço fiscal para educação e saúde nos próximos anos, o critério "contratos celebrados a partir de 3 de dezembro de 2012" restringe ainda mais a vinculação de recursos no curto prazo.

Lima (2013a), com base em informações da BP, mostra que a exploração comercial dos poços de petróleo do pré-sal só deve começar de 11 a 18 anos após a assinatura do contrato. A declaração de comercialidade só ocorre, em média, oito anos após a assinatura de contrato. Ou seja, especialmente no caso de estados, Distrito Federal e municípios, a destinação de recursos para educação e saúde só deve começar a ocorrer a partir de 2022, considerando uma projeção otimista.

Levando em conta esses critérios, as tabelas 9 e 10 mostram projeções (realista e otimista, respectivamente) de destinação de participações governamentais do petróleo para educação e saúde até 2022.

Tabela 9 - Projeção de royalties e participações especiais destinados à educação e saúde em R \$ bilhões - cenário realista - 2013-2022

\begin{tabular}{|c|c|c|c|c|c|}
\hline Ano & $\begin{array}{c}\text { União (declaração } \\
\text { de comercialidade } \\
\text { a partir de } \\
3 / 12 / 2012)\end{array}$ & $\begin{array}{c}\text { Estados e municípios } \\
\text { (contratos a partir de } \\
3 / 12 / 2012)\end{array}$ & Fundo social (50\%) & Unitização & Total \\
\hline 2013 & 0,00 & 0,00 & 5,80 & 0,29 & 6,09 \\
\hline 2014 & 0,01 & 0,00 & 1,72 & 0,44 & 2,17 \\
\hline 2015 & 0,08 & 0,00 & 7,71 & 0,58 & 8,37 \\
\hline 2016 & 0,67 & 0,00 & 4,68 & 1,17 & 6,52 \\
\hline 2017 & 2,24 & 0,00 & 10,61 & 1,31 & 14,16 \\
\hline 2018 & 4,73 & 0,00 & 7,07 & 7,88 & 19,68 \\
\hline 2019 & 8,19 & 0,00 & 14,53 & 7,88 & 30,59 \\
\hline 2020 & 10,69 & 0,00 & 11,06 & 7,74 & 29,49 \\
\hline 2021 & 11,62 & 0,00 & 16,88 & 7,59 & 36,08 \\
\hline 2022 & 11,40 & 0,00 & 12,04 & 7,45 & 30,88 \\
\hline Total & 49,63 & 0,00 & 92,09 & 42,33 & 184,04 \\
\hline
\end{tabular}

Fonte: elaboração dos autores com base em Brasil (2013d) e ANP (2014).

\footnotetext{
${ }^{12}$ Disponível em: <www.planalto.gov.br/ccivil_03/_Ato2011-2014/2013/Lei/L12858.htm>. Acesso em: 21 dez. 2013.
} 
Tabela 10 - Projeção de royalties e participações especiais destinados à educação e saúde em R\$ bilhões - cenário otimista - 2013- 2022

\begin{tabular}{|c|c|c|c|c|c|}
\hline Ano & $\begin{array}{c}\text { União (declaração } \\
\text { de comercialidade } \\
\text { a partir de } \\
\text { 3/12/2012) }\end{array}$ & $\begin{array}{c}\text { Estados e municípios } \\
\text { (contratos a partir de } \\
3 / 12 / 2012)\end{array}$ & Fundo social (50\%) & Unitização & Total \\
\hline 2013 & 0,00 & 0,00 & 5,80 & 0,29 & 6,09 \\
\hline 2014 & 0,01 & 0,00 & 1,72 & 0,44 & 2,17 \\
\hline 2015 & 0,08 & 0,00 & 7,71 & 0,58 & 8,37 \\
\hline 2016 & 0,67 & 0,00 & 4,68 & 1,17 & 6,52 \\
\hline 2017 & 2,24 & 0,00 & 10,61 & 1,31 & 14,16 \\
\hline 2018 & 4,73 & 0,00 & 7,07 & 7,88 & 19,68 \\
\hline 2019 & 8,19 & 0,00 & 14,53 & 7,88 & 30,59 \\
\hline 2020 & 10,69 & 0,00 & 11,06 & 7,74 & 29,49 \\
\hline 2021 & 11,62 & 0,00 & 16,88 & 7,59 & 36,08 \\
\hline 2022 & 11,40 & 26,59 & 12,04 & 7,45 & 57,48 \\
\hline Total & 49,63 & 26,59 & 92,09 & 42,33 & 210,63 \\
\hline
\end{tabular}

Fonte: elaboração dos autores com base em Brasil (2013d) e ANP (2014).

Considerando um cenário realista, com a inclusão dos recursos de unitização, ${ }^{13}$ a educação e a saúde receberiam juntas, entre 2013 e 2022, cerca de R\$ 184 bilhões. Levando em conta sua participação no total, a saúde teria à disposição cerca de $\mathrm{R} \$ 46$ bilhões no período em análise. Nesse caso, todo o repasse de royalties para a área social seria oriundo da União.

Já em um cenário otimista, que considera o repasse de estados e municípios (apenas) em 2022, o montante auferido pelas duas áreas ao longo dos dez anos da série subiria para R\$210,6 bilhões, sendo R $\$ 52,7$ bilhões destinados exclusivamente à saúde.

Nossa estimativa realista se aproxima muito da projeção apontada por Lima (2013b): enquanto o autor chega à cifra de $\mathrm{R} \$ 130$ bilhões, sem unitização, no mesmo horizonte temporal, nossa conta registrou R $\$ 141,7$ bilhões, também sem unitização. Estima-se que da

receita governamental direta de $\mathrm{R} \$ 1,52$ trilhão, 32\% serão destinados às áreas de educação e saúde, o que equivale a cerca de $\mathrm{R} \$ 486$ bilhões no período de 2013 a 2030. De 2013 a 2022, os recursos destinados a essas áreas seriam da ordem de $\mathrm{R} \$ 130$ bilhões, sem considerar recursos de unitização que podem chegar a R\$ 40 bilhões nesse período. (Lima, 2013b: 2)

Com base em estimativas apontadas nos pareceres legislativos (Brasil, 2013a, 2013b) e de Lima (2013b), pode-se inferir a evolução futura dos recursos provenientes dos royalties do petróleo que seriam destinados à saúde e à educação. O Gráfico 6 apresenta essa projeção, com ênfase na saúde.

\footnotetext{
13 "Unitização é a operação conjunta, coordenada, de um reservatório de petróleo, por todos os detentores de direitos nas seções sobrepondo o reservatório" (Quintas, 2010: 16).
} 
Gráfico 6 - Estimativa de recursos para educação e saúde a partir dos royalties do petróleo - 2013-2030

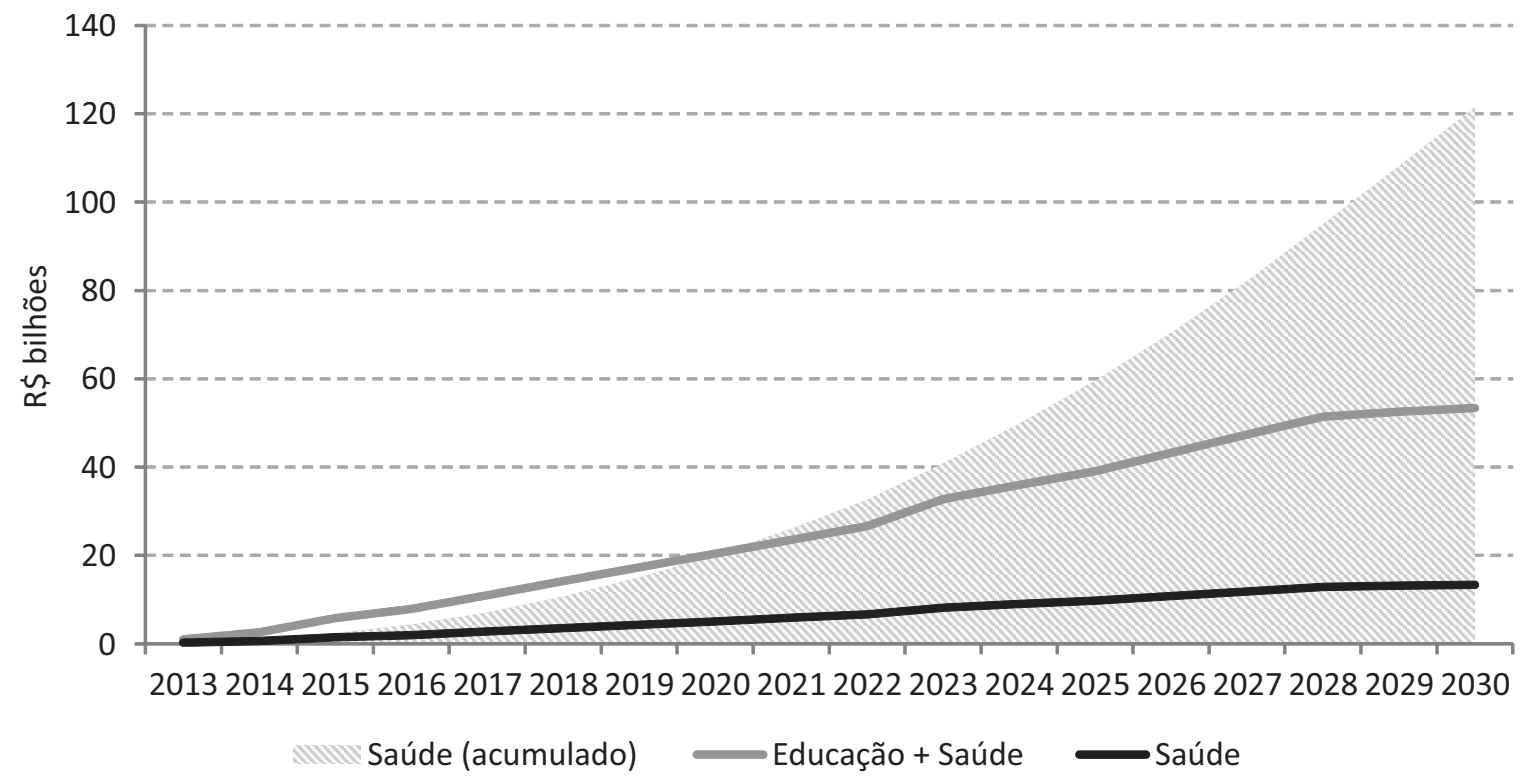

Fonte: elaboração própria com base em dados de Brasil (2013a), Brasil (2013b) e Lima (2013b).

Como apenas 25\% dos recursos destinam-se à saúde, da estimativa de $\mathrm{R} \$ 486$ bilhões a serem repassados até 2030, o setor só obterá $\mathrm{R} \$ 121,5$ bilhões aproximadamente no mesmo horizonte temporal. No último ano da projeção, a saúde receberia cerca de $\mathrm{R} \$ 13,3$ bilhões extras (além da vinculação constitucional, dada hoje pela EC n. 29) para adicionar ao seu orçamento.

Certamente é um recurso que contribui para a melhora do setor, mas é muito aquém do necessário. Basta comparar tal receita com a CSS, que, em 2013, já destinaria R\$19,2 bilhões à saúde. Supondo que esses R $\$ 13,3$ bilhões fossem acrescidos ao orçamento de 2013, especificamente para os gastos com ASPS, notaríamos um incremento da ordem de $15 \%$, passando o gasto de $\mathrm{R} \$ 88,3$ bilhões para R\$ 101,6 bilhões.

De acordo com Lima (2013a), alguns fatores podem ser apontados para a baixa destinação de receita dos royalties para a saúde.

- Com relação aos royalties e participação especial distribuídos para estados e municípios, o critério de declaração de comercialidade, que tenha ocorrido a partir de 3 de dezembro de 2012, foi substituído pelo critério de assinatura de contrato. Dessa forma, somente a partir de 2022, royalties e participação especial deverão ser destinados às áreas de educação e saúde por esses entes da federação.

- Não houve garantia de se destinar, no mínimo, $60 \%$ do excedente em óleo para a União. ${ }^{14}$ Sem isso, não se garante que o regime de partilha de produção gere receitas substancialmente

\footnotetext{
${ }^{14}$ No regime de concessão, a participação especial é semelhante ao excedente em óleo e, nos grandes campos, varia de $30 \%$ a $40 \%$ da receita líquida. Se a introdução do regime de partilha de produção em áreas estratégicas teve o objetivo de aumentar a renda do estado, nada mais justo que se estabeleça um excedente em óleo da União de, no mínimo, 60\%.
} 
maiores que as do regime de concessão, argumentação muito utilizada no Congresso Nacional por ocasião da discussão do novo marco legal.

- Não foi possível destinar às áreas de educação e saúde recursos referentes a acordos de unitização celebrados entre a Pré-Sal Petróleo S.A. (PPSA) e futuros concessionários ou contratados sob o regime de partilha de produção. ${ }^{15}$

- Quando comparada com as outras áreas do horizonte geológico do pré-sal, a participação da Petrobras em Libra é bem menor. Essa menor participação da Petrobras e o baixo excedente em óleo para a União, nos termos do edital de Libra, não representam, na prática, uma melhora do atual cenário de receitas governamentais.

- A destinação imediata de recursos é a mais prejudicada, o que tem relação direta com o prazo para o início da exploração dos poços. É muito grande o intervalo de tempo entre o ano da celebração do contrato de concessão e a instalação de unidades estacionárias de produção. O intervalo de tempo médio para esse regime é de 16,3 anos. Sob o regime de concessão na plataforma continental, não deverão ser geradas receitas significativas de royalties e de participação especial decorrentes de contratos celebrados a partir de 3 de dezembro de 2012. As receitas governamentais significativas nos próximos anos virão de áreas já contratadas.

Resultado direto dos problemas mencionados é a baixa participação da receita governamental brasileira na atividade extrativa em questão. Uma breve comparação internacional, apresentada no Gráfico 7, mostra como o país se posiciona desfavoravelmente na classificação de participação da renda do petróleo.

Os dados apresentados no Gráfico 7 estão ligeiramente defasados, especialmente no caso brasileiro. A despeito da posição oficial do governo, que afirma que a participação governamental total (incluindo o retorno da Petrobras) no campo de Libra será de 85\% da renda gerada (Brasil, 2013g), Lima (2013b) sugere que essa participação seria significativamente menor - em torno de 70\% -, visto que os parâmetros utilizados pelo governo para estimar sua participação são irreais.

Considerando essa participação governamental (baseada em Libra) de 70\% da receita bruta de exploração, o Brasil ainda poderia ser classificado como um país em que o Estado tem baixa participação na renda do petróleo, mesmo tendo melhorado o indicador com relação à posição de 2006, quando, de acordo com a ANP, seu government take girava em torno de $60 \%$ da receita. Dados mais atualizados ${ }^{16}$ mostram que países como Angola, Venezuela, Rússia e Noruega têm participações superiores a $80 \%$. Na China esse percentual chega a $90 \%$.

\footnotetext{
${ }^{15}$ Nos termos do texto aprovado no Senado, a ANP deixa de ser obrigada a prestar essas informações, prejudicando a transparência e o direito à informação pelos cidadãos.

${ }^{16}$ Disponível em: <www2.camara.leg.br/documentos-e-pesquisa/publicacoes/estnottec/areas-da-conle/ tema16/2013_17543.pdf>. Acesso em: dez. 2013.
} 
Gráfico 7 - Participação governamental na exploração de petróleo - 2007

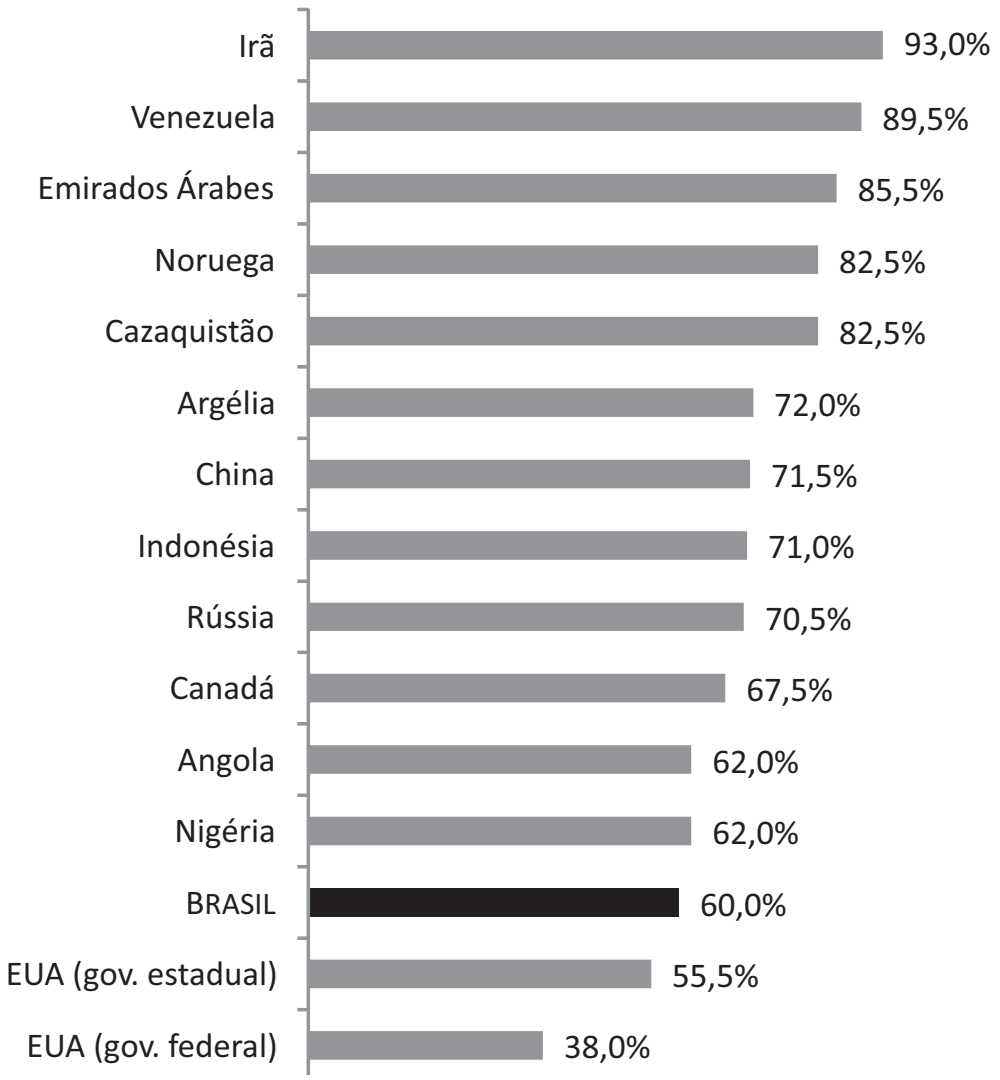

Fonte: PWC, 2009.

Em resumo, havia um enorme potencial de obtenção de recursos com a exploração do pré-sal. Porém, se o resultado final ficar bem abaixo do esperado, é razoável supor que as receitas previstas para a saúde dessa fonte não sejam significativas a ponto de resolver a questão do financiamento do setor.

A lei que estabeleceu o marco regulatório da exploração de petróleo e gás natural pelo regime de partilha de produção - lei n. 2.734 de 30 de novembro de 2012 - também se destacou pela mudança nos critérios de distribuição dos royalties e participações especiais entre estados e municípios. A atuação teve o objetivo de descentralizar o destino dos recursos, impondo uma maior participação às localidades que não são afetadas nem são confrontantes das áreas de exploração. Uma análise criteriosa dos impactos dessa mudança se faz necessária para mostrar quais localidades sairiam perdendo ou ganhando e para identificar um maior ou menor equilíbrio na distribuição de recursos.

Utilizando dados consolidados pela ANP, de distribuição de royalties para União, estados e municípios por unidade da federação (UF) para o ano de 2013 e os coeficientes de participação de cada UF no Fundo de Participação dos Estados e do Distrito Federal (FPE) e no Fundo de Participação 
dos Municípios (FPM), obtidos no Tribunal de Contas da União (TCU), foi possível estimar a participação de cada UF (incluindo estados e municípios) no total de royalties, de acordo com os dois critérios de distribuição (o critério antigo, mas ainda vigente, e o critério da lei n. 12.734, suspenso temporariamente).

Como pode ser observado nos mapas da Figura 1, em que são apresentados os resultados finais, há uma aparente melhora na distribuição dos recursos dos royalties, entendendo melhora como uma distribuição menos centralizada. Unidades federativas que recebem menos de $0,1 \%$ dos recursos pelo critério vigente (AC, AP, RO, RR), passariam a se enquadrar na categoria seguinte de distribuição (de $0,1 \%$ a 1\%). Pelos novos critérios, a maior parte das UFs - 18 ao todo - teriam uma participação entre 1\% e 5\% (classificação intermediária, de cor amarela). Além disso, a Bahia passaria a integrar o grupo das UFs que recebem mais de 5\% dos royalties, junto do Rio de Janeiro e Espírito Santo, que já se encontram nessa posição pelos atuais critérios de distribuição.

De uma forma geral, a mudança da distribuição de participação mostra várias UFs tendo pequenos incrementos, enquanto Rio de Janeiro, Espírito Santo e Rio Grande do Norte teriam redução de suas respectivas parcelas. O caso mais drástico seria o do Rio de Janeiro, que de uma fatia da ordem de $37,9 \%$ na regra vigente, passaria a deter $18,6 \%$ - uma queda de mais da metade da participação de origem (Cf. Tabela 25 no Anexo).

Deve-se atentar para o fato de que esta simulação conta com critérios do ano de 2013. Eventuais mudanças na participação das diferentes localidades decorrentes da localização dos poços de exploração (alteração na classificação de localidades confrontantes/afetadas) e de rateio do FPE/FPM devem ser levadas em conta em simulações para anos subsequentes. Ademais, como o primeiro leilão sob o regime de partilha foi o de Libra, os dados mencionados só se referem ao regime de concessão de cessão onerosa, aplicado no caso.

A inclusão de novas áreas de exploração pode (deve) alterar o padrão de distribuição regional dos recursos, assim como a obsolescência de áreas em fim de ciclo produtivo. De qualquer forma, a distribuição encontrada nesse cálculo é uma referência razoável que parte de fontes fidedignas.

Em se tratando de gastos públicos com saúde, não importa apenas tentar mensurar o volume de recursos que devem beneficiar o setor nos próximos anos. Intrínseca à questão dos royalties do petróleo está a distribuição regional dessa compensação financeira. Esse aspecto é extremamente importante, por envolver disputa federativa muito delicada e engendrar uma apropriação de recursos que não se assemelha às prioridades alocativas do SUS.

A simulação aqui realizada afetará a base vinculável de estados e municípios, se mantida a EC n. 29, alterando significativamente os valores efetivamente destinados pelos governos subnacionais ao financiamento da saúde e à distribuição intraestadual e intramunicipal, além de alterar os volumes a serem integralizados pelas três esferas de governo e sua participação relativa, neste e em qualquer outro cenário de alocação de recursos para a saúde. 
Figura 1 - Distribuição regional dos royalties do petróleo em \% do total - 2013
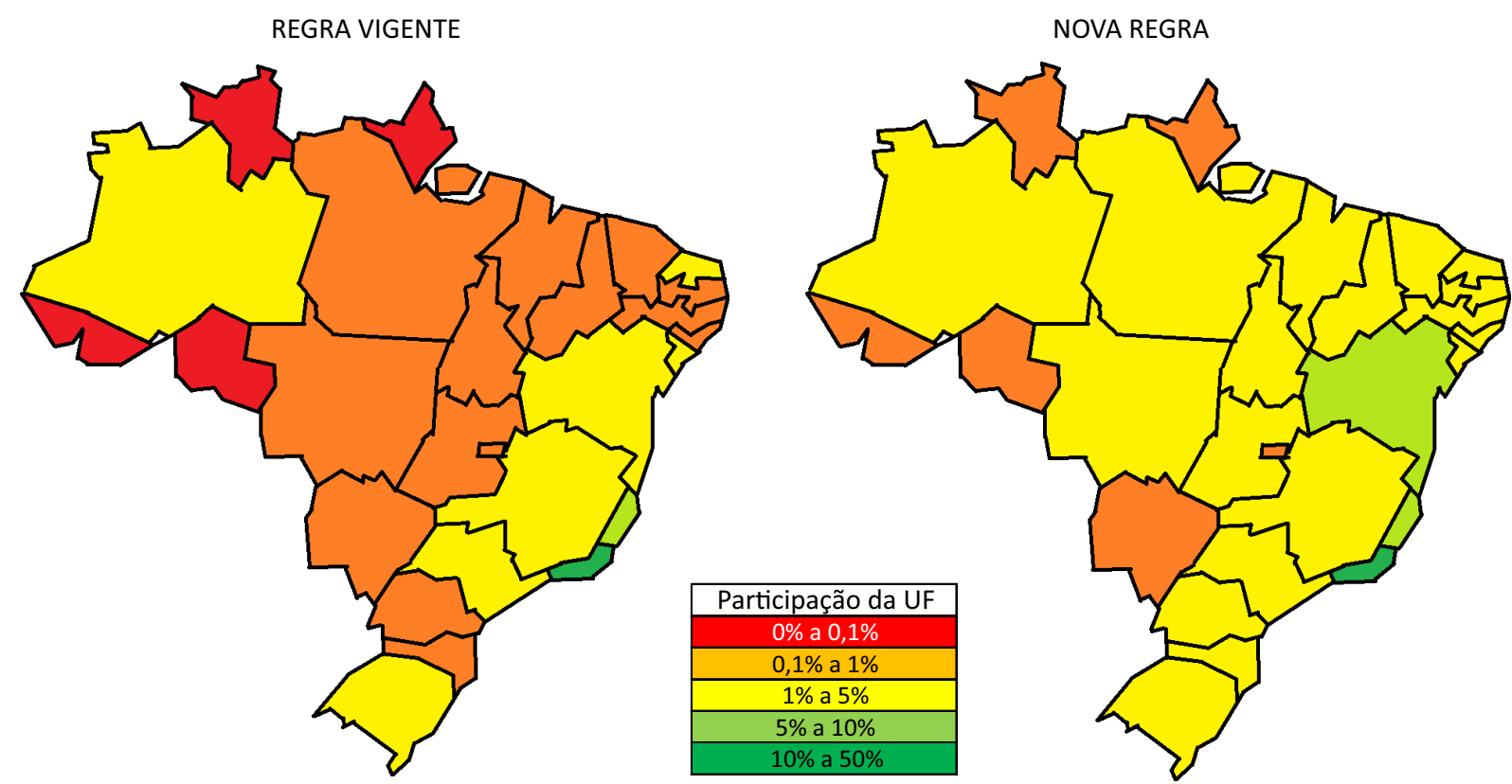

Fontes: ANP (2014), TCU (2014).

\section{Espaço Fiscal: a questão da renúncia fiscal}

O financiamento da saúde envolve não apenas propostas de novas fontes de recursos ou de mudanças institucionais no campo tributário, mas também a capacidade de gasto do governo. Em tese, a simples situação de maior aporte de receita e menor necessidade de gastos em outras funções já seria suficiente para o poder público ampliar seu dispêndio em saúde.

A perda de capacidade do governo de cumprir seus compromissos, ou a redução do espaço fiscal do setor público, tem relação direta com as desonerações tributárias promovidas em favor do setor privado. Tal tema torna-se especialmente relevante após o crescimento desse tipo de política nos últimos anos no âmbito do governo federal, como item integrante de sua agenda de incentivo ao crescimento econômico.

De fato, boa parcela da resposta do governo central à crise internacional dos últimos anos se localizou na renúncia fiscal. Exemplos mais comuns foram a redução do IPI para automóveis, a desoneração da folha de pagamentos (previdência) e a redução do IR sobre a participação sobre lucros e rendimentos. Houve ainda renúncias com objetivo explícito de controle inflacionário, como a desoneração da cesta básica e a redução da Cide-combustíveis.

Esse tipo de desoneração tem influência indireta na capacidade de gasto do governo com ASPS e, apesar de ser importante, não deve ser confundida com a renúncia fiscal promovida especificamente no setor em questão. Ou seja, além dos gastos tributários já citados que limitam o orçamento 
como um todo, deve-se atentar para os gastos tributários que favorecem a atuação do setor de saúde privado (planos de saúde, entidades filantrópicas, medicamentos etc.). A mensuração e observação das duas linhas de desoneração são muito importantes para uma melhor compreensão do efetivo espaço fiscal com que se depara a União atualmente.

A desoneração tributária em qualquer nível é relevante não apenas para a discussão de espaço fiscal, como aqui proposta. O favorecimento do setor privado de saúde por meio de tributos contribui também significativamente para perpetuar o baixo nível de gasto público em saúde no Brasil. A preocupação em torno desse subfinanciamento público da saúde, e sua sustentação via incentivos ao setor privado, está relacionada à ideia de desigualdade de renda.

A maior parte da renúncia fiscal na função saúde é concedida às pessoas físicas que têm gastos com saúde em geral (hospitais, médicos, planos de saúde, dentistas, medicamentos etc.). Usualmente essas pessoas beneficiadas estão enquadradas em classes de renda mais elevadas. Ou seja, há um gasto tributário do setor público para financiar o tratamento de saúde privado em detrimento da melhora do aparelho público de atendimento, ao qual todos os cidadãos têm acesso. Os recursos públicos aplicados no setor "devem beneficiar toda a população brasileira, e não somente a parcela que usa o sistema privado" (Gadelha, Carvalho \& Pereira, 2012: 175).

O volume de recursos despendido pelo governo federal com renúncias específicas para o setor de saúde foi da ordem de $\mathrm{R} \$ 18$ bilhões em 2012, sendo 48,5\% desse total (R \$ 8,7 bilhões) exclusivos em "despesas médicas", rubrica que está relacionada às deduções de saúde do IR. A Tabela 11 apresenta os dados de renúncia de 2012 detalhados por região.

Os outros itens de renúncia fiscal também se relacionam com tributos específicos: "assistência médica, odontológica e farmacêutica a empregados" - IRPJ (Imposto sobre a Renda das Pessoas Jurídicas); "entidades sem fins lucrativos/ assistência social" - IRPJ, CSLL e Cofins; e "medicamentos", "produtos químicos e farmacêuticos", "água mineral" - PIS, Cofins.

Regionalmente a Tabela 11 mostra que há uma maior concentração de renúncia fiscal na região Sudeste. Isso pode ser comprovado tanto pelo dado per capita, que indica um benefício médio anual de $\mathrm{R} \$ 149,68$ (bem acima da média nacional, de $\mathrm{R} \$ 93,06$ ), quanto pelo dado relativo, que indica que quase $68 \%$ dos recursos do país foram destinados à região economicamente mais desenvolvida. Tal informação é muito relevante, na medida em que reforça a tese de que o incentivo ao mercado privado contribui para o aumento da desigualdade de renda. Nesse caso específico, a contribuição não se dá apenas no âmbito da renda: acentua-se também a desigualdade regional. Regiões que têm claras deficiências de recursos físicos e humanos no setor de saúde recebem relativamente menos incentivos tributários que as mais avançadas. 
Tabela 11 - Estimativa de gasto tributário da união por função orçamentária em $\mathrm{R} \$$ correntes, em $\mathrm{R} \$$ per capita e em \% do total - 2012

\begin{tabular}{|c|c|c|c|c|c|c|c|}
\hline \multicolumn{8}{|l|}{$\mathrm{R} \$$ correntes } \\
\hline \multirow{2}{*}{$\begin{array}{c}\text { Função } \\
\text { orçamentária }\end{array}$} & \multirow{2}{*}{ Gasto tributário } & \multicolumn{5}{|c|}{ Região } & \multirow{2}{*}{ Brasil } \\
\hline & & Norte & Nordeste & Centro-Oeste & Sudeste & Sul & \\
\hline \multirow{7}{*}{ Saúde } & Despesas médicas & 437.614 .023 & 1.326 .811 .652 & 1.004 .595 .124 & 4.932 .865 .130 & 1.053 .356 .309 & 8.755 .242 .238 \\
\hline & $\begin{array}{l}\text { Assit. médica, } \\
\text { odont. e farm. a } \\
\text { empregados }\end{array}$ & 67.294 .084 & 162.424 .215 & 277.607.126 & 2.293 .833 .618 & 321.617 .952 & 3.122.776.995 \\
\hline & $\begin{array}{l}\text { Produtos químicos } \\
\text { e farmacêuticos }\end{array}$ & 252.603 & 5.083 .355 & 49.960 .160 & 563.902 .473 & 58.413 .760 & 677.612 .351 \\
\hline & $\begin{array}{l}\text { Entidades sem } \\
\text { fins lucrativos - } \\
\text { assistência social }\end{array}$ & 36.371 .695 & 230.134 .644 & 268.944 .004 & 1.532.060.399 & 333.395 .183 & 2.400 .905 .925 \\
\hline & Água mineral & 2.237 .675 & 4.870 .310 & 1.524 .484 & 3.122 .743 & 1.354 .787 & 13.109 .999 \\
\hline & Medicamentos & 0 & 17.083 .642 & 98.581 .175 & 2.882 .868 .650 & 80.077 .064 & 3.078.610.531 \\
\hline & Total & 543.770 .080 & 1.746 .407 .818 & 1.701.212.073 & 12.208 .653 .013 & 1.848 .215 .055 & 18.048 .258 .039 \\
\hline \multicolumn{8}{|l|}{$\mathrm{R} \$$ per capita } \\
\hline \multirow{2}{*}{$\begin{array}{c}\text { Função } \\
\text { orçamentária }\end{array}$} & \multirow{2}{*}{ Gasto tributário } & \multicolumn{5}{|c|}{ Região } & \multirow{2}{*}{ Brasil } \\
\hline & & Norte & Nordeste & Centro-Oeste & Sudeste & Sul & \\
\hline \multirow{7}{*}{ Saúde } & Despesas médicas & 26,82 & 24,61 & 69,65 & 60,48 & 37,98 & 45,14 \\
\hline & $\begin{array}{l}\text { Assit. médica, } \\
\text { odont. e farm. a } \\
\text { empregados }\end{array}$ & 4,12 & 3,01 & 19,25 & 28,12 & 11,60 & 16,10 \\
\hline & $\begin{array}{l}\text { Produtos químicos } \\
\text { e farmacêuticos }\end{array}$ & 0,02 & 0,09 & 3,46 & 6,91 & 2,11 & 3,49 \\
\hline & $\begin{array}{l}\text { Entidades sem } \\
\text { fins lucrativos - } \\
\text { assistência social }\end{array}$ & 2,23 & 4,27 & 18,65 & 18,78 & 12,02 & 12,38 \\
\hline & Água mineral & 0,14 & 0,09 & 0,11 & 0,04 & 0,05 & 0,07 \\
\hline & Medicamentos & 0,00 & 0,32 & 6,83 & 35,34 & 2,89 & 15,87 \\
\hline & Total & 33,32 & 32,40 & 117,94 & 149,68 & 66,65 & 93,06 \\
\hline \multicolumn{8}{|l|}{$\%$ do total } \\
\hline \multirow{2}{*}{$\begin{array}{c}\text { Função } \\
\text { orçamentária }\end{array}$} & \multirow{2}{*}{ Gasto tributário } & \multicolumn{5}{|c|}{ Região } & \multirow{2}{*}{ Brasil } \\
\hline & & Norte & Nordeste & Centro-Oeste & Sudeste & Sul & \\
\hline \multirow{7}{*}{ Saúde } & Despesas médicas & $5,00 \%$ & $15,15 \%$ & $11,47 \%$ & $56,34 \%$ & $12,03 \%$ & $100,00 \%$ \\
\hline & $\begin{array}{l}\text { Assit. médica, } \\
\text { odont. e farm. a } \\
\text { empregados }\end{array}$ & $2,15 \%$ & $5,20 \%$ & $8,89 \%$ & $73,45 \%$ & $10,30 \%$ & $100,00 \%$ \\
\hline & $\begin{array}{l}\text { Produtos } \\
\text { químicos e } \\
\text { farmacêuticos }\end{array}$ & $0,04 \%$ & $0,75 \%$ & $7,37 \%$ & $83,22 \%$ & $8,62 \%$ & $100,00 \%$ \\
\hline & $\begin{array}{l}\text { Entidades sem } \\
\text { fins lucrativos - } \\
\text { assistência aocial }\end{array}$ & $1,51 \%$ & $9,59 \%$ & $11,20 \%$ & $63,81 \%$ & $13,89 \%$ & $100,00 \%$ \\
\hline & Água mineral & $17,07 \%$ & $37,15 \%$ & $11,63 \%$ & $23,82 \%$ & $10,33 \%$ & $100,00 \%$ \\
\hline & Medicamentos & $0,00 \%$ & $0,55 \%$ & $3,20 \%$ & $93,64 \%$ & $2,60 \%$ & $100,00 \%$ \\
\hline & Total & $3,01 \%$ & $9,68 \%$ & $9,43 \%$ & $67,64 \%$ & $10,24 \%$ & $100,00 \%$ \\
\hline
\end{tabular}

Fonte: elaboração dos autores com base em Brasil (2013e) e IBGE (2016). 
Com efeito, o avanço dos gastos tributários em favor do mercado privado de saúde no Brasil (WHO, 2006, 2010) foi notado pelo governo federal, que em 2009 lançou um programa para reduzir desigualdades e melhorar o sistema público de saúde (Brasil, 2009), cuja primeira iniciativa era justamente limitar e reduzir, gradativamente, a renúncia fiscal do setor. O resultado, até 2012, foi positivo e pode ser visto no Gráfico 8.

Gráfico 8 - Participação da função saúde no gasto tributário total da União - 2008-2012

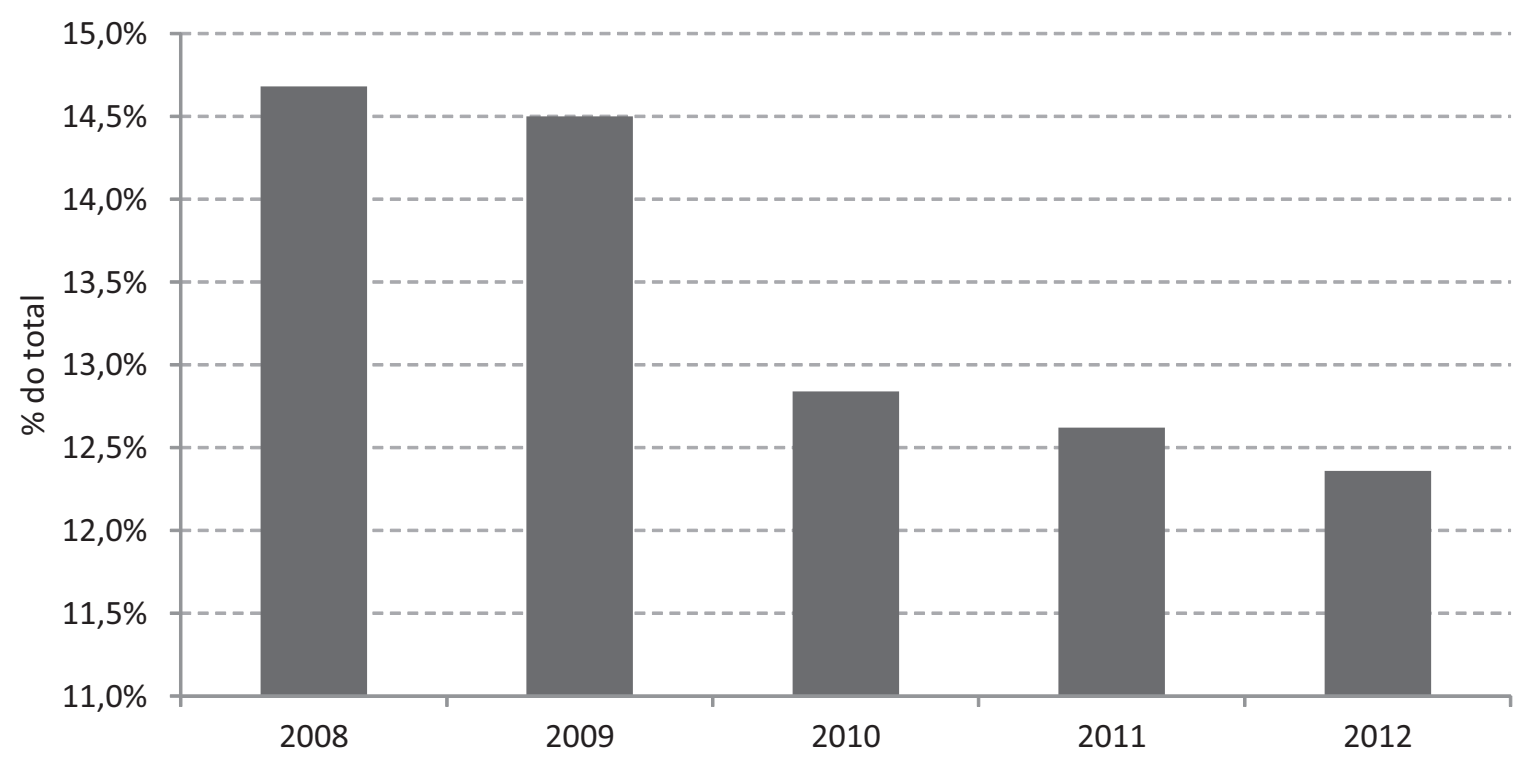

Fonte: elaboração própria com base em dados de Brasil, 2013e.

A despeito do aumento absoluto (em valores correntes) da renúncia fiscal do setor entre 2008 e 2012 - passando de $\mathrm{R} \$ 14,6$ bilhões para $\mathrm{R} \$ 18$ bilhões -, em termos relativos à renúncia tem havido redução. Se em 2008 a desoneração tributária em favor da saúde privada representava 14,68\% de toda a renúncia promovida pelo governo central, em 2012 esse percentual caiu para 12,36\% do total. Observa-se que a queda do indicador foi progressiva ao longo dos cinco anos englobados no Gráfico 8.

Mais do que isso, Ocké-Reis (2013) mostra que o gasto tributário com saúde (ou a renúncia fiscal em favor do mercado privado) apresentou diminuição na participação do total do gasto federal de 2008 a 2011. Em 2008 a participação era de 28,3\%, ao passo que em 2011 o percentual caiu para $22,5 \%$ do total.

Se é possível observar uma tendência de arrefecimento da renúncia fiscal direta no setor de saúde, o mesmo não pode ser afirmado em relação aos benefícios fiscais aplicados aos demais setores. Como já adiantado no início desta seção, nos últimos anos o governo federal tem se valido dessa possibilidade para estimular a atividade econômica ou para controlar a inflação. Diversos setores produtivos foram beneficiados pelos subsídios, como se pode observar na Tabela 12 (Diniz \& Afonso, 2014). 
Tabela 12 - Estimativa de benefícios fiscais concedidos pelo governo federal - 2011-2014

\begin{tabular}{|c|c|c|c|c|c|c|c|c|c|c|}
\hline \multirow{2}{*}{ Item } & \multicolumn{4}{|c|}{$\%$ do PIB } & Variação & \multicolumn{4}{|c|}{ R\$ bilhões constantes } & Variação \\
\hline & 2011 & 2012 & 2013E & $2014 \mathrm{E}$ & 2014-2011 & 2011 & 2012 & 2013E & 2014E & 2014-2011 \\
\hline PIB nominal/IPCA (\%) & 4.143 & 4.403 & 4.974 & 5.243 & - & 6,50 & 5,84 & 5,94 & 6,01 & - \\
\hline Benefícios & $1,09 \%$ & $0,98 \%$ & $1,41 \%$ & $1,40 \%$ & $0,31 \%$ & 50,48 & 45,54 & 69,97 & 69,25 & $37,18 \%$ \\
\hline Financeiros & $0,28 \%$ & $0,19 \%$ & $0,42 \%$ & $0,56 \%$ & $0,28 \%$ & 13,00 & 9,09 & 20,66 & 27,63 & $112,54 \%$ \\
\hline Creditícios & $0,78 \%$ & $0,76 \%$ & $0,98 \%$ & $0,83 \%$ & $0,05 \%$ & 36,06 & 35,62 & 48,52 & 40,96 & $13,59 \%$ \\
\hline $\begin{array}{l}\text { Financeiros/ } \\
\text { Creditícios }\end{array}$ & $0,03 \%$ & $0,02 \%$ & $0,02 \%$ & $0,01 \%$ & $-0,02 \%$ & 1,42 & 0,83 & 0,79 & 0,66 & $-53,52 \%$ \\
\hline $\begin{array}{l}\text { Gastos tributários } \\
\text { e renúncias } \\
\text { previdenciárias }\end{array}$ & $3,65 \%$ & $3,92 \%$ & $4,10 \%$ & $4,76 \%$ & $1,12 \%$ & 169,34 & 182,85 & 203,76 & 235,61 & $39,13 \%$ \\
\hline Gastos tributários & $3,15 \%$ & $3,32 \%$ & $3,42 \%$ & $3,67 \%$ & $0,52 \%$ & 146,46 & 154,68 & 170,02 & 181,75 & $24,10 \%$ \\
\hline $\begin{array}{l}\text { Renúncias } \\
\text { previdenciárias }\end{array}$ & $0,49 \%$ & $0,60 \%$ & $0,68 \%$ & $1,09 \%$ & $0,60 \%$ & 22,88 & 28,17 & 33,74 & 53,86 & $135,40 \%$ \\
\hline $\begin{array}{l}\text { Total - benefícios } \\
\text { fiscais }\end{array}$ & $4,73 \%$ & $4,90 \%$ & $5,50 \%$ & $6,16 \%$ & $1,43 \%$ & 219,82 & 228,39 & 273,73 & 304,86 & $38,69 \%$ \\
\hline
\end{tabular}

Nota: $\mathrm{E}=$ estimativa

Fonte: Diniz \& Afonso, 2014: 8.

Nota-se que, em um período de apenas três anos, o nível total de benefícios fiscais concedidos pelo governo federal deve ter crescido 1,43\% do PIB, saindo de um patamar de 4,73\% do PIB em 2011 para 6,16\% em 2014. A taxa de crescimento real do benefício acumulada no período seria de quase $39 \%$.

Interessante é a observação de que o volume de benefício fiscal fornecido pela União - que, na análise de Diniz e Afonso (2014), não inclui apenas isenção e redução de tributos ${ }^{17}$ - é tão alto que poderia ser facilmente enquadrado como um dos principais ministérios em termos de orçamento: "se os benefícios constituíssem um ministério fictício, seria inferior apenas ao da Previdência Social e superaria o da Saúde e da Educação juntos" (Diniz \& Afonso, 2014: 6-7). Ou seja, o volume de recursos concedidos pelo setor público federal é alto o suficiente para financiar com facilidade o incremento de recursos que o setor de saúde precisa.

Em 2013 o maior programa de renúncia fiscal promovido pelo governo central foi a desoneração da folha de pagamentos. As medidas com esse objetivo se iniciaram no final de 2011, com a medida provisória (MP) n. 540, de 8 de agosto de 2011. Com a posterior conversão em lei n. 12.546 , de 14 de dezembro de 2011, o prazo de vigência do benefício foi estendido até o final

\footnotetext{
${ }^{17}$ Os autores também incluem benefícios financeiros e creditícios, além dos gastos tributários e previdenciários, na lista de benefícios fiscais. Estimava-se que em 2014 essas vantagens concedidas pelo governo central representassem pouco mais de $22 \%$ de todos os benefícios fiscais promovidos no mesmo ano. De acordo com a Secretaria de Política Econômica (Brasil, 2013h), não houve, em 2013, benefícios financeiros e/ou creditícios ao setor de saúde.
} 
de 2014 e novos setores foram incluídos. Nas leis n. 12.715, de 17 de setembro de 2012, e n. 12.844, de 19 de julho de 2013, mais setores foram incluídos no processo, com o estabelecimento de novas regras para esses setores.

Com a ampliação do benefício para mais áreas produtivas, o volume de renúncia fiscal foi ampliado significativamente em 2014. De acordo com análises sobre a arrecadação das receitas federais, em 2013, a folha de pagamentos deixou de recolher R\$ 13,2 bilhões (Brasil, 2013f). Em 2012, essa renúncia totalizou, em valores correntes, $\mathrm{R} \$ 3,7$ bilhões. Atualizando os valores pelo Índice Nacional de Preços ao Consumidor Amplo (IPCA), observa-se um crescimento de mais de 235\% entre 2012 e 2013 no benefício fiscal em questão.

No inciso IV do artigo $9^{\circ}$ da lei n. 12.546/20,11 afirma-se que:

a União compensará o Fundo do Regime Geral de Previdência Social, de que trata o art. 68 da Lei Complementar $n^{\circ} 101$, de 4 de maio de 2000, no valor correspondente à estimativa de renúncia previdenciária decorrente da desoneração, de forma a não afetar a apuração do resultado financeiro do Regime Geral de Previdência Social (RGPS).

Ou seja, deve haver compensação financeira, por parte do Tesouro, ao sistema previdenciário no montante que foi renunciado. Assim, o processo de renúncia da folha de pagamento impacta diretamente no resultado (espaço) fiscal do governo e na alocação de recursos no interior do Orçamento da Seguridade Social, comprometendo, consequentemente, seus gastos.

A desoneração em curso representou muito mais do que uma diminuição dos encargos que estão associados à folha de pagamentos das empresas. Ela foi também um grande processo de renúncia fiscal, ao qual se somam inúmeros outros. Naturalmente, o efeito dessa subtração de receitas, mesmo que dela não resultassem prejuízos para a Previdência Social, precisa ser analisado em conjunto com a capacidade fiscal do Estado de financiar o pleno funcionamento dos programas federais e dos diversos direitos a eles associados. (Zanghelini et al., 2013: 66)

Além da desoneração associada à folha de pagamentos, as tabelas 13, 14 e 15 evidenciam o impacto da desoneração sobre a Cofins, PIS-Pasep e CSLL na redução dos recursos disponíveis para gastos da seguridade social. No caso da Cofins, a desoneração fiscal em 2012 superou o percentual da DRU. Para o PIS-Pasep e CSLL, a desoneração foi ligeiramente inferior aos recursos contingenciados pela DRU, mas ainda muito significativa. 
Tabela 13 - Receitas da Cofins em valores correntes, \% do PIB e estimativa de renúncias - 2005-2012

\begin{tabular}{|l|r|r|r|r|r|r|r|r|}
\hline Parcelas da Cofins & 2005 & \multicolumn{1}{|c|}{2006} & \multicolumn{1}{|c|}{2007} & 2008 & 2009 & 2010 & 2011 & \multicolumn{1}{c|}{2012} \\
\hline Receita do principal & 85.015 & 88.368 & 99.918 & 117.682 & 114.208 & 138.427 & 157.968 & 169.102 \\
\hline Parcelamentos & 1.695 & 824 & 790 & 898 & 609 & 237 & 205 & 10.063 \\
\hline Dívida ativa & 145 & 206 & 391 & 592 & 1.123 & 372 & 458 & 865 \\
\hline Juros e multas & 2.742 & 942 & 736 & 921 & 820 & 988 & 974 & 1.525 \\
\hline TotAL GERAL & 89.597 & 90.341 & 101.835 & 120.094 & 116.759 & 140.023 & 159.625 & 181.555 \\
\hline \% do PIB & 4,2 & 3,8 & 3,8 & 4 & 3,6 & 3,7 & 3,9 & 4,1 \\
\hline RENÚNCIAS & 5.411 & 9.810 & 13.351 & 20.058 & 29.419 & 33.883 & 35.046 & 39.200 \\
\hline \% RENÚNCIAS & 6,4 & 11,1 & 13,4 & 17 & 25,8 & 24,5 & 22,2 & 23,2 \\
\hline
\end{tabular}

Fonte: Zanghelini \& colaboradores, 2013.

Tabela 14 - Receitas do PIS em valores correntes, \% do PIB e estimativa de renúncias - 2005-2012

\begin{tabular}{|l|r|r|r|r|r|r|r|r|}
\hline Parcelas da Cofins & 2005 & 2006 & 2007 & 2008 & 2009 & 2010 & 2011 & 2012 \\
\hline Receita do principal & 21.015 & 23.067 & 25.639 & 30.178 & 30.327 & 39.967 & 41.115 & 44.596 \\
\hline Parcelamentos & 323 & 354 & 180 & 187 & 139 & 50 & 46 & 2.461 \\
\hline Dívida ativa & 44 & 73 & 83 & 177 & 310 & 93 & 143 & 234 \\
\hline Juros e multas & 701 & 321 & 214 & 288 & 254 & 262 & 280 & 447 \\
\hline Restituições & 0 & 0 & 0 & 0 & 0 & 0 & 439 & 40 \\
\hline TOTAL GERAL & 2.083 & 3.815 & 6.116 & 30.830 & 31.030 & 40.372 & 2.023 & 47.778 \\
\hline \% do PIB & 1,03 & 1,01 & 0,98 & 1,02 & 0,96 & 1,07 & 1,01 & 1,09 \\
\hline RENÚNCIAS & 1.317 & 2.435 & 2.377 & 3.733 & 5.651 & 6.955 & 6.702 & 7.695 \\
\hline \% RENÚNCIAS & 6,3 & 10,6 & 9,3 & 12,4 & 18,6 & 17,4 & 16,3 & 17,3 \\
\hline
\end{tabular}

Fonte: Zanghelini \& colaboradores, 2013.

Tabela 15 - Receitas da CSLL em valores correntes, \% do PIB e estimativa de renúncias - 2005-2012

\begin{tabular}{|l|r|r|r|r|r|r|r|r|}
\hline Parcelas da Cofins & 2005 & 2006 & 2007 & 2008 & 2009 & 2010 & 2011 & 2012 \\
\hline Receita do principal & 24.671 & 26.441 & 33.070 & 41.527 & 42.725 & 45.162 & 56.930 & 53.772 \\
\hline Parcelamentos & 325 & 128 & 149 & 168 & 105 & 46 & 42 & 2.375 \\
\hline Dívida ativa & 52 & 93 & 111 & 259 & 280 & 145 & 137 & 494 \\
\hline Juros e multas & 1.183 & 604 & 313 & 548 & 482 & 400 & 475 & 678 \\
\hline Restituições & 0 & 0 & 0 & 0 & 0 & 0 & 261 & 170 \\
\hline TotAL GERAL & 26.232 & 27.266 & 33.644 & 42.502 & 43.592 & 45.754 & 57.845 & 57.489 \\
\hline \% do PIB & 1,22 & 1,15 & 1,26 & 1,4 & 1,35 & 1,21 & 1,4 & 1,31 \\
\hline RENÚNCIAS & 2.022 & 2.535 & 2.958 & 4.525 & 6.087 & 8.333 & 5.821 & 6.755 \\
\hline \% RENÚNCIAS & 8,2 & 9,6 & 8,9 & 10,9 & 14,2 & 18,5 & 10,2 & 12,6 \\
\hline
\end{tabular}

Fonte: Zanghelini \& colaboradores, 2013. 
Se estas renúncias fossem adicionadas ao financiamento da saúde, poderiam cobrir as necessidades de recursos pleiteadas na emenda ao Orçamento Impositivo e nas demais tentativas de vinculação de receita pretendidas pelo setor. Entretanto, o espaço fiscal existente foi utilizado no favorecimento de setores industriais e de serviços, por meio de cessões de receita sem contrapartida de adesão às políticas econômicas que as motivaram, de ativação do crescimento econômico.

\section{Financiamento, Gasto Público em Saúde e Redistribuição}

A existência de espaço fiscal e sua destinação às políticas sociais, notadamente à saúde e educação, tem impacto potencial sobre a redistribuição de renda e a redução da desigualdade, a depender do balanço entre a geração da receita pública e a alocação da despesa.

Com base em pesquisas sobre incidência tributária e gastos sociais sobre os orçamentos familiares, ${ }^{18}$ é possível estimar o balanço entre o impacto do financiamento e do gasto social sobre a desigualdade nos anos contemplados nessas pesquisas.

Estudo realizado pelo Ipea para o período de 2003 a 2009 (Ipea, 2011), atesta que a regressividade do sistema tributário tem sido compensada pela progressividade do gasto social, notadamente dos gastos com educação e saúde públicas, além de despesas previdenciárias e assistenciais. Indica também, nos últimos anos, a maior ênfase na alocação do gasto social nos estratos de renda mais baixos, que acentuam a direção da progressividade.

O desdobramento desses estudos em análises sobre a relação entre gasto social e tributação nos orçamentos familiares (Silveira, 2012; Silveira et al., 2013) revela que esse impacto foi positivo entre 2003 e 2009 - ou seja, houve um crescimento no gasto social sem contrapartida de elevação na carga tributária suportada pelas famílias. Mais ainda, o balanço entre a incidência e o gasto, que, em 2003, era positivo até o sétimo décimo de renda, se tornou positivo até o nono décimo de renda em 2009 (Silveira, 2012).

A avaliação dos impactos distributivos da tributação e da política de seguridade social (transferências de renda e oferta de serviços públicos universais como saúde e educação) pode ser evidenciada por indicadores que permitem comparar a concentração de renda antes e depois das políticas de financiamento e gasto mencionadas.

Para destacar e singularizar os impactos distributivos decorrentes da relação entre arrecadação e gasto social, é possível acompanhar as etapas da redistribuição de renda, avaliando os impactos sobre a renda inicial de benefícios sociais, tributação direta e indireta e dos gastos universais em saúde e educação, como na Figura 2.

\footnotetext{
${ }^{18}$ Os dados apresentados pelo Ipea (2011) são estimados com base na Pesquisa de Orçamento Familiar (POF) e na Pesquisa Nacional por Amostra de Domicílios (Pnad), organizadas pelo Instituto Brasileiro de Geografia e Estatística (IBGE), para os anos 2002-2003 e 2008-2009.
} 
Figura 2 - Estágios da distribuição de renda

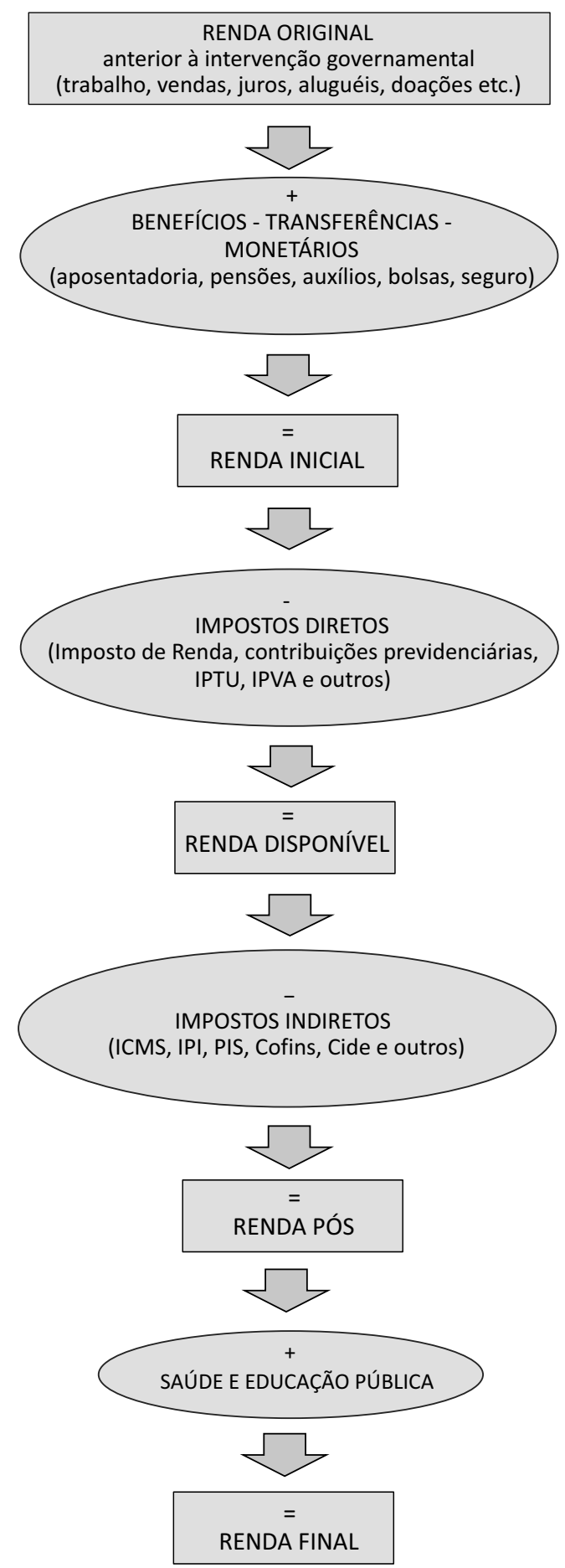

Fonte: Ipea, 2011: 17. 
Na comparação entre 2003 e 2009 realizada por Silveira (2012), o maior impacto sobre a redução da desigualdade, medida pelo índice de Gini, resulta da evolução favorável dos gastos em saúde e educação, como mostra o Gráfico 9.

O índice de Gini descreve a dinâmica distributiva (progressiva ou regressiva) de cada um desses estágios da renda das famílias. (...) revela redução da desigualdade até a renda disponível, indicando progressividade distributiva (i) nos benefícios previdenciários e (ii) na tributação direta da renda. Essa equalização é revertida parcialmente quando se calcula o Gini para a renda após os impostos indiretos, mostrando o caráter regressivo desse tipo de tributação. A trajetória de redução da desigualdade e de progressividade distributiva é reforçada pela distribuição dos gastos sociais em saúde e em educação. (Ipea, 2011: 4)

Gráfico 9 - Comportamento do índice de Gini e das rendas totais (original, inicial, disponível, pós-tributação e final). ${ }^{19}$ Brasil - 2003 e 2009

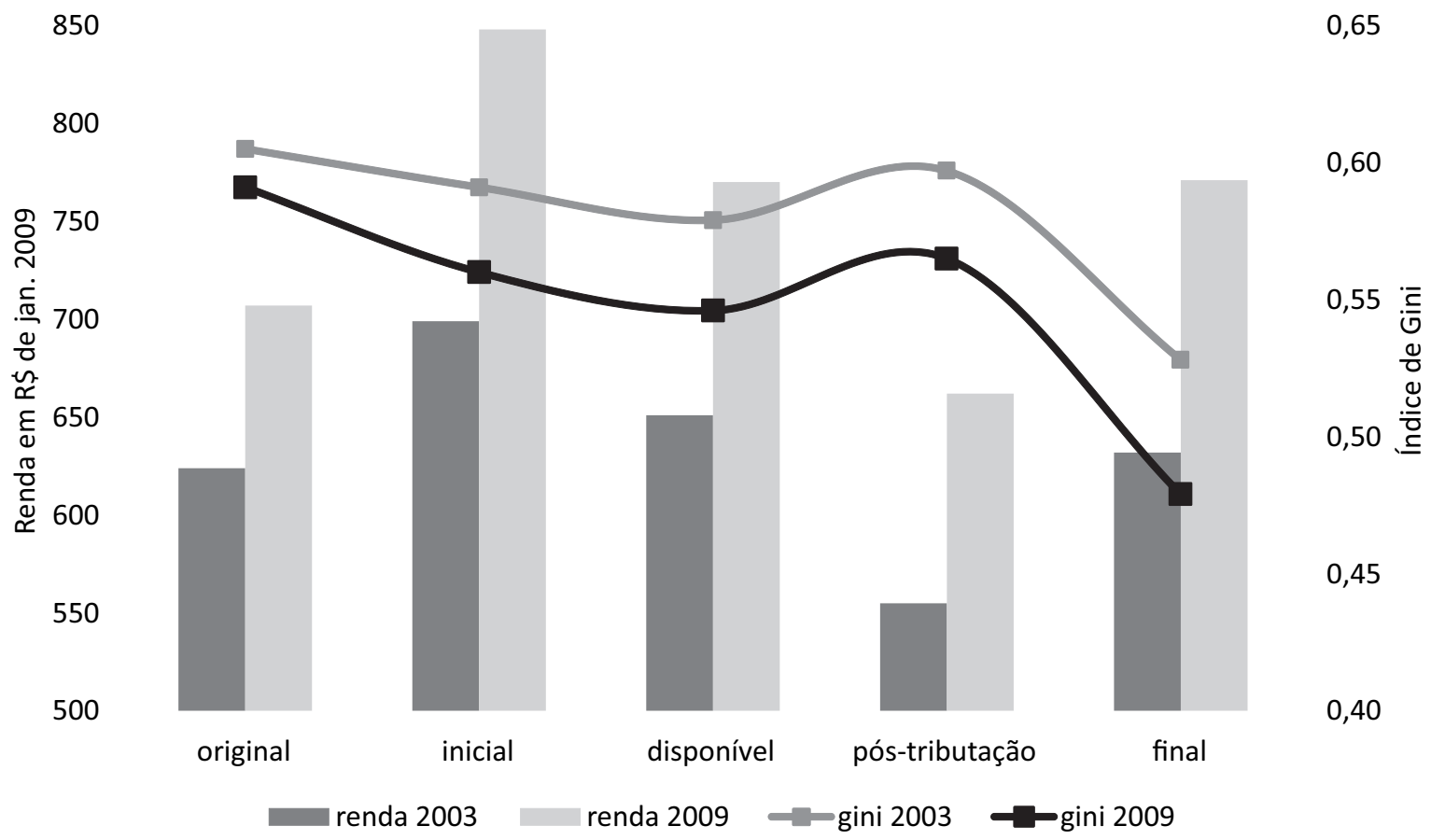

Fonte: Silveira, 2012.

As políticas previdenciárias e assistenciais responderam por queda de 5,2\% no índice de Gini da renda monetária inicial, entre 2003 e 2009, e praticamente não houve redução adicional da desigual-

\footnotetext{
${ }^{19}$ As barras que representam a renda domiciliar per capita média mostram os diferentes estágios da renda segundo a intervenção do Estado: 1) renda original, que considera todos os rendimentos exceto os benefícios recebidos pelas famílias; 2) renda inicial, que considera a renda original somada aos benefícios; 3) renda disponível, que corresponde à renda inicial deduzido o pagamento de impostos diretos; 4) renda pós-tributação, que deduz da renda disponível o pagamento dos impostos indiretos. Por fim, ao somar o valor monetário dos benefícios em espécie - saúde e educação públicas - chega-se à (5) renda final. Os dados estão expressos em valores mensais domiciliares per capita, em R\$ de janeiro de 2009.
} 
dade por efeito tributário no período. Em 2009, o índice da renda final (pós-tributação e modificada pelo gasto em saúde e educação) é 9,3\% menor que o de 2003, quase duplicando a queda na desigualdade alcançada por efeito das políticas previdenciária e assistencial. Essa queda ocorre porque os gastos de educação e de saúde têm participação expressiva e crescente na renda - de 15\% para 16.9\% entre 2003 e 2009 - e, sobretudo, no caso dos gastos de saúde, apresentam baixos coeficientes de concentração, o que explica seu maior impacto distributivo.

Silveira (2012), com base em estimativas sobre o perfil do gasto em saúde nos orçamentos familiares, simula a distribuição do gasto público federal em saúde na estrutura da renda monetária familiar per capita, como se pode constatar na Tabela 16, e conclui pela progressividade dos gastos em saúde, destacando-se a política de internações. O autor ressalta que

os $40 \%$ mais pobres da população se apropriam de cerca da metade dos gastos com internações hospitalares e de $45 \%$ das despesas com procedimentos ambulatoriais frente a uma participação da ordem de $10 \%$ para os $20 \%$ mais ricos. Na composição do total das despesas, cabe à metade mais pobre pouco mais de $55 \%$ frente a uma participação de $1 / 5$ para os $30 \%$ mais ricos. (Silveira, 2012: 59)

Tabela 16 - Distribuição do gasto público federal em saúde, segundo rubricas de gasto e por décimos de renda -2008

\begin{tabular}{|c|c|c|c|c|c|c|}
\hline Décimos & Total & Internações & $\begin{array}{c}\text { Procedimentos } \\
\text { ambulatoriais }\end{array}$ & $\begin{array}{c}\text { Bens e serviços } \\
\text { universais }\end{array}$ & $\begin{array}{c}\text { Servidores } \\
\text { públicos federais }\end{array}$ & Medicamentos \\
\hline $1^{\circ}$ & 10,0 & 12,5 & 10,5 & 10,6 & 11,3 & 7,6 \\
\hline $2^{\circ}$ & 11,0 & 13,0 & 11,8 & 9,9 & 11,7 & 8,2 \\
\hline $3^{\circ}$ & 11,3 & 11,3 & 12,0 & 10,0 & 11,4 & 12,1 \\
\hline $4^{\circ}$ & 10,7 & 11,2 & 11,1 & 10,1 & 11,4 & 8,5 \\
\hline $5^{\circ}$ & 11,3 & 11,9 & 11,5 & 9,9 & 11,2 & 10,7 \\
\hline $6^{\circ}$ & 12,7 & 14,3 & 12,7 & 10,0 & 11,5 & 15,7 \\
\hline $7^{\circ}$ & 10,5 & 9,2 & 10,4 & 10,0 & 10,1 & 10,1 \\
\hline $8^{\circ}$ & 9,6 & 7,5 & 9,4 & 9,9 & 9,1 & 11,0 \\
\hline $9^{\circ}$ & 8,4 & 6,2 & 7,6 & 9,8 & 7,3 & 11,3 \\
\hline $0^{\circ}$ & 4,7 & 3,1 & 3,1 & 9,8 & 4,9 & 4,9 \\
\hline
\end{tabular}

Fonte: Silveira, 2012: 60.

Do ponto de vista macroeconômico, é possível concluir que a materialização dos gastos sociais associados às políticas universais de educação e saúde desempenha importante papel como política redistributiva redutora da desigualdade da renda final dos consumidores.

O compromisso com a significativa e necessária ampliação dos recursos dedicados ao gasto público em saúde pode também impactar os investimentos setoriais nos três níveis de governo, dentro da lógica de descentralização e regionalização da oferta de ASPS vigente no SUS. Se tais compromissos 
estiverem pautados pela busca de equalização no acesso e na utilização dos serviços, poderão intensificar, por meio da política específica do setor, o impacto do ganho de progressividade indicado nas pesquisas de orçamentos familiares.

\section{Espaço Fiscal: cenários macroeconômicos para 2034}

A análise de curto prazo realizada até aqui - avaliação da evolução dos gastos efetivos da União na saúde e do cumprimento da EC n. 29, simulação de impacto das diferentes propostas de vinculação para a área, verificação das demais alternativas de financiamento, verificação do impacto da renúncia fiscal nos gastos da função - é muito importante na medida em que proporciona um retrato da atual situação do financiamento da saúde pelo governo federal.

Entretanto, expandir essa análise para o longo prazo significa dinamizá-la, procurando visualizar as perspectivas para o setor. As perguntas que serão feitas nesta seção são: com quais cenários macroeconômicos nos depararemos nos próximos vinte anos? Esses cenários são favoráveis para um maior volume de gasto social, especialmente em saúde? Como as propostas de vinculação de gasto aqui apresentadas se comportariam dentro desses cenários? Quais são as limitações dessas projeções?

A primeira pergunta a ser respondida é justamente a última. Duas referências são utilizadas para construção de cenários macroeconômicos de longo prazo: os estudos realizados pela Fiocruz (Gadelha, Carvalho \& Pereira, 2012) e pela LCA Consultoria (2013). Ambos os trabalhos fazem projeções de indicadores macros até o ano de 2030, os quais foram estendidos até 2034 para a análise aqui proposta.

As duas referências utilizadas trabalham com diferentes cenários. No caso do estudo da Fiocruz (Gadelha, Carvalho \& Pereira, 2012), há a apresentação de três cenários: otimista (possível), pessimista (plausível) e conservador (provável). Há diferenciação de boa parte dos indicadores macros dentre esses três diferentes cenários. No caso da LCA (2013), há a apresentação de dois cenários: cenário-base (otimista) e cenário adverso (conservador). Vale atentar que, apesar do nome, o cenário adverso da LCA Consultoria apresenta projeções mais otimistas do que o cenário conservador estabelecido na pesquisa da Fiocruz.

Todas as projeções apontadas nos dois estudos referem-se às médias do período em análise. Ou seja, o estudo feito pela Fiocruz, ao indicar que o crescimento no cenário otimista será de $4 \%$ a. a. até 2030, na verdade está assinalando que o crescimento médio anual será de 4\% a. a., podendo em alguns (ou em todos) anos a taxa de crescimento oscilar para mais ou para menos.

Essa conclusão óbvia decorre do fato, empiricamente comprovado, de que a economia capitalista trabalha em ciclos, com períodos de prosperidade e crescimento da atividade, seguido de períodos de depressão de retração econômica. Além disso, há uma possibilidade razoável de que as projeções médias estejam incorretas, haja vista a dificuldade de estimar indicadores macros para um prazo tão distante.

A Tabela 17 apresenta um resumo da projeção macro realizada pelo estudo da Fiocruz (Gadelha, Carvalho \& Pereira, 2012). Como pode ser notado, os resultados das variáveis apresentam muita 
diferença entre si conforme se muda de cenário, com exceção da inflação que fica no centro da meta $(4,5 \%)$ em todos os cenários. O estudo apresenta 17 indicadores, que podem ser classificados como os mais relevantes dentro da análise macroeconômica.

Tabela 17 - Cenários macroeconômicos para 2030

\begin{tabular}{|c|c|c|c|}
\hline Variável relevante & Cenário otimista & Cenário pessimista & Cenário conservador \\
\hline PIB & R\$ 8.260 bilhões & R\$ 4.277 bilhões & R\$ 5.602 bilhões \\
\hline População & \multicolumn{3}{|c|}{216.410 .030} \\
\hline Renda per capita & $\mathrm{R} \$ 38.240,00$ & $\mathrm{R} \$ 19.763,50$ & $\mathrm{R} \$ 25.935,00$ \\
\hline Taxa de crescimento & $4,0 \%$ a.a & $0,63 \%$ a.a. & $2,0 \%$ a.a. \\
\hline Taxa de desemprego & Cai & Aumenta & $\begin{array}{l}\text { Permanece no mesmo } \\
\text { nível }\end{array}$ \\
\hline Salário mínimo & $\mathrm{R} \$ 1.118,00$ & $\mathrm{R} \$ 578,00$ & $\mathrm{R} \$ 758,00$ \\
\hline $\begin{array}{l}\text { Rendimento médio do pessoal } \\
\text { ocupado }\end{array}$ & $\begin{array}{l}\text { Crescimento superior } \\
\text { ao da renda per capita }\end{array}$ & $\begin{array}{l}\text { Crescimento inferior ao } \\
\text { da renda per capita }\end{array}$ & $\begin{array}{l}\text { Crescimento semelhante } \\
\text { ao da renda per capita }\end{array}$ \\
\hline Índice de Gini & 0,4 & 0,6 & 0,6 \\
\hline $\begin{array}{l}\text { Rendimentos do trabalho } \\
\text { (participação no PIB) }\end{array}$ & Melhoria pronunciada & $\begin{array}{c}\text { Permanece no mesmo } \\
\text { nível }\end{array}$ & Melhoria moderada \\
\hline $\begin{array}{l}\text { Resultado primário (governo } \\
\text { central) }\end{array}$ & Cai significativamente & Aumenta & $\begin{array}{c}\text { Permanece no mesmo } \\
\text { nível }\end{array}$ \\
\hline Resultado primário (\% PIB) & Cai significativamente & Aumenta & Cai moderadamente \\
\hline Serviço da dívida pública & Cai significativamente & Aumenta & Cai moderadamente \\
\hline Taxa de juros (Selic) & $1,65 \%$ & $10,67 \%$ & $4,35 \%$ \\
\hline Taxa de câmbio & $\mathrm{R} \$ 2,50$ & $\mathrm{R} \$ 1,80$ & $\mathrm{R} \$ 2,00$ \\
\hline Saldo do balanço comercial & Sobe & \multicolumn{2}{|c|}{ Permanece no mesmo nível } \\
\hline Déficit em transações correntes & Cai & \multicolumn{2}{|c|}{ Permanece no mesmo nível } \\
\hline Inflação (IPCA) & \multicolumn{3}{|c|}{$4,50 \%$} \\
\hline
\end{tabular}

Fonte: Teixeira \& Vianna, 2016.

O estudo da LCA Consultoria é mais atual, o que acarreta projeções menos incertas, e apresenta projeção para 76 indicadores macros e micros, o que torna sua análise mais ampla e completa. Fornece resultados numéricos para todos os indicadores e subdivide períodos na sua projeção (média de 2015-2020 e média de 2021-2030), o que melhora a análise, dado que essa diferenciação entre períodos se coaduna com a ideia de ciclos, apontada anteriormente. Assim, as projeções realizadas no estudo da Fiocruz são tomadas como segunda referência para avaliar se as projeções da primeira são razoáveis ou não.

Explicada a escolha, vale ainda alertar que os dados da LCA Consultoria (2013) foram complementados no curto prazo por Bacen (2014). Este último apresenta projeções mais atualizadas para 2014 e 2015. Dessa forma, as projeções para esses dois anos mais próximos foram substituídas para estimativas mais atuais, com o intuito de tornar a análise mais confiável. 
A Tabela 18 apresenta um resumo das projeções macroeconômicas que serão utilizadas, considerando apenas as variáveis mais relevantes para a análise aqui proposta.

Tabela 18 - Resumo das projeções macroeconômicas de acordo com dois cenários - 2014-2034

\begin{tabular}{|c|c|c|c|c|c|c|c|}
\hline \multirow[b]{2}{*}{ Ano } & \multirow{2}{*}{$\begin{array}{c}\text { Taxa de } \\
\text { crescimento } \\
\text { real }\end{array}$} & \multirow{2}{*}{$\begin{array}{c}\text { Inflação } \\
\text { (IPCA) }\end{array}$} & \multirow{2}{*}{$\begin{array}{c}\text { Selic } \\
\text { (\% a. a.) }\end{array}$} & \multicolumn{4}{|c|}{$\%$ do PIB } \\
\hline & & & & $\begin{array}{c}\text { Juros } \\
\text { nominais }\end{array}$ & $\begin{array}{c}\text { Resultado } \\
\text { primário }\end{array}$ & $\begin{array}{c}\text { Déficit } \\
\text { nominal }\end{array}$ & DLSP \\
\hline \multicolumn{8}{|l|}{ Cenário-base } \\
\hline 2014 & $1,7 \%$ & $6,5 \%$ & $11,3 \%$ & $5,5 \%$ & $2,5 \%$ & $3,0 \%$ & $34,9 \%$ \\
\hline 2015 & $2,0 \%$ & $6,0 \%$ & $12,0 \%$ & $5,5 \%$ & $2,5 \%$ & $3,0 \%$ & $35,0 \%$ \\
\hline 2016-2020 & $3,6 \%$ & $5,3 \%$ & $8,3 \%$ & $4,5 \%$ & $1,8 \%$ & $2,7 \%$ & $29,7 \%$ \\
\hline 2021-2034 & $3,8 \%$ & $4,3 \%$ & $6,8 \%$ & $4,1 \%$ & $1,5 \%$ & $2,6 \%$ & $27,6 \%$ \\
\hline \multicolumn{8}{|c|}{ Cenário adverso } \\
\hline 2014 & $1,7 \%$ & $6,5 \%$ & $11,3 \%$ & $5,5 \%$ & $2,5 \%$ & $3,0 \%$ & $34,9 \%$ \\
\hline 2015 & $2,0 \%$ & $6,0 \%$ & $12,0 \%$ & $5,5 \%$ & $2,5 \%$ & $3,0 \%$ & $35,0 \%$ \\
\hline 2016-2020 & $2,9 \%$ & $5,5 \%$ & $9,0 \%$ & $5,0 \%$ & $2,0 \%$ & $3,0 \%$ & $30,6 \%$ \\
\hline 2021-2034 & $3,6 \%$ & $4,4 \%$ & $7,8 \%$ & $3,8 \%$ & $1,5 \%$ & $2,3 \%$ & $25,9 \%$ \\
\hline
\end{tabular}

Nota: DLSP = Dívida Líquida do Setor Público.

Fonte: elaboração própria com base em Bacen (2014) e LCA Consultoria (2013).

Nota-se que os anos de 2014 e 2015, por serem contíguos, apresentam projeções iguais nos dois cenários. Em termos de crescimento econômico, a maior diferença entre os cenários propostos se dá no período 2016-2020, que, no cenário-base, fica em 3,6\% a. a. e, no cenário adverso, em 2,9\% a. a. Outro ponto que chama atenção é que, nesse caso, há menor discrepância entre cenários do que no caso das estimativas feitas no estudo da Fiocruz (Gadelha, Carvalho \& Pereira, 2012).

Para estimar a evolução dos gastos da União com ASPS segundo os diversos critérios apresentados anteriormente, algumas variáveis-chave deveriam ser projetadas. No caso da EC n. 29, a taxa real de crescimento do PIB mais a inflação já seriam suficientes para fazer a conta. Porém, para os outros critérios seria necessário estimar variáveis de receita da União (RCB, RCL e base ampliada da proposta de Dornelles). Para se chegar a essas bases, optou-se por estimar a carga tributária bruta (CTB) para o período 2014-2034, para posteriormente tentar verificar a RCB, a RCL e a base ampliada. Considerou-se que a CTB apresentaria uma evolução positiva independente do cenário, diferenciando-se apenas a intensidade do crescimento do cenário-base para o cenário adverso. O Gráfico 10 apresenta a evolução estimada da CTB para o período selecionado. 
Gráfico 10 - Projeção da carga tributária bruta - 2014-2034

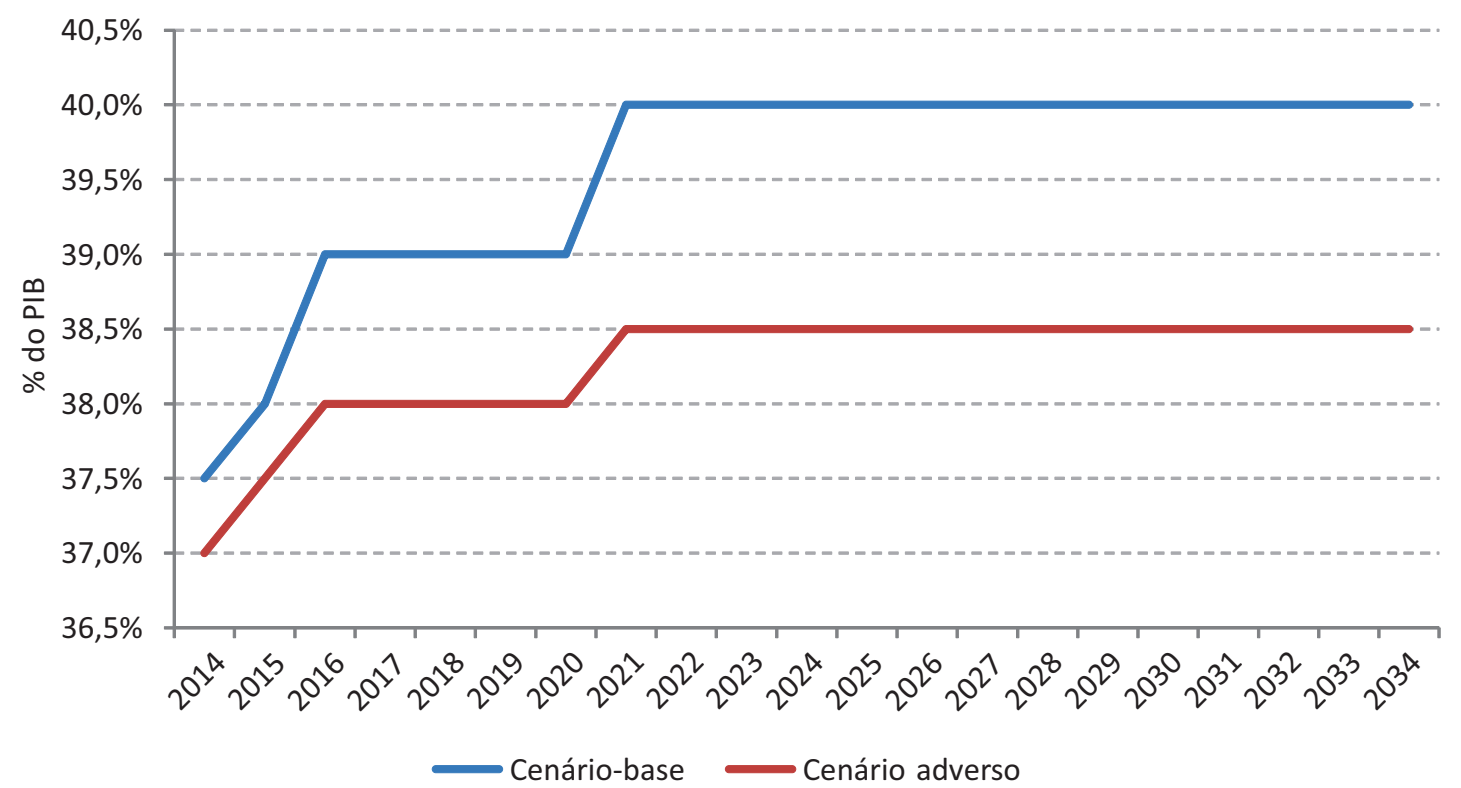

Fonte: elaboração dos autores com base em Bacen (2014) e LCA Consultoria (2013).

A projeção da CTB apresenta períodos de estabilidade por ser baseada nas projeções de outras variáveis macros da LCA Consultoria (2013). Mais uma vez, deve-se reforçar a ideia de que isso não significa que a CTB será estável por cinco ou dez anos, mas que dentro desses períodos há uma média, o que permite variação da CTB para mais ou para menos a cada ano.

Como é de se esperar, a evolução do gasto com ASPS da União sob os critérios de vinculação de receita terá relação direta com a evolução da CTB, apresentando exatamente as mesmas tendências. As variáveis determinantes (bases de cálculo) para apurar o gasto em saúde sob os critérios já discutidos (PLP 01/2003, PEC do Orçamento Impositivo e proposta de reforma tributária Dornelles) foram calculadas a partir de suas participações na CTB de 2013. Por exemplo, a RCB da União de 2013 representou 67,8\% da CTB. Tal percentual foi aplicado para todos os anos da projeção (2014 a 2034), podendo ser apurada assim a RCB do governo federal no mesmo período. Para que tal procedimento fosse adotado, partiu-se da hipótese de que não haveria alterações nas relações federativas fiscais (mudanças na participação da receita disponível dos entes da federação) e na composição da base de incidência da CTB (mudanças na participação de cada tributo na formação da CTB).

Levando em conta esses aspectos metodológicos, os gráficos 11 e 12 apresentam a evolução projetada dos gastos do governo central com ASPS para o período em análise, de acordo com os dois cenários macroeconômicos propostos. 
Gráfico 11 - Projeção dos gastos da União com ASPS sob diversos critérios, cenário-base - 2014-2034

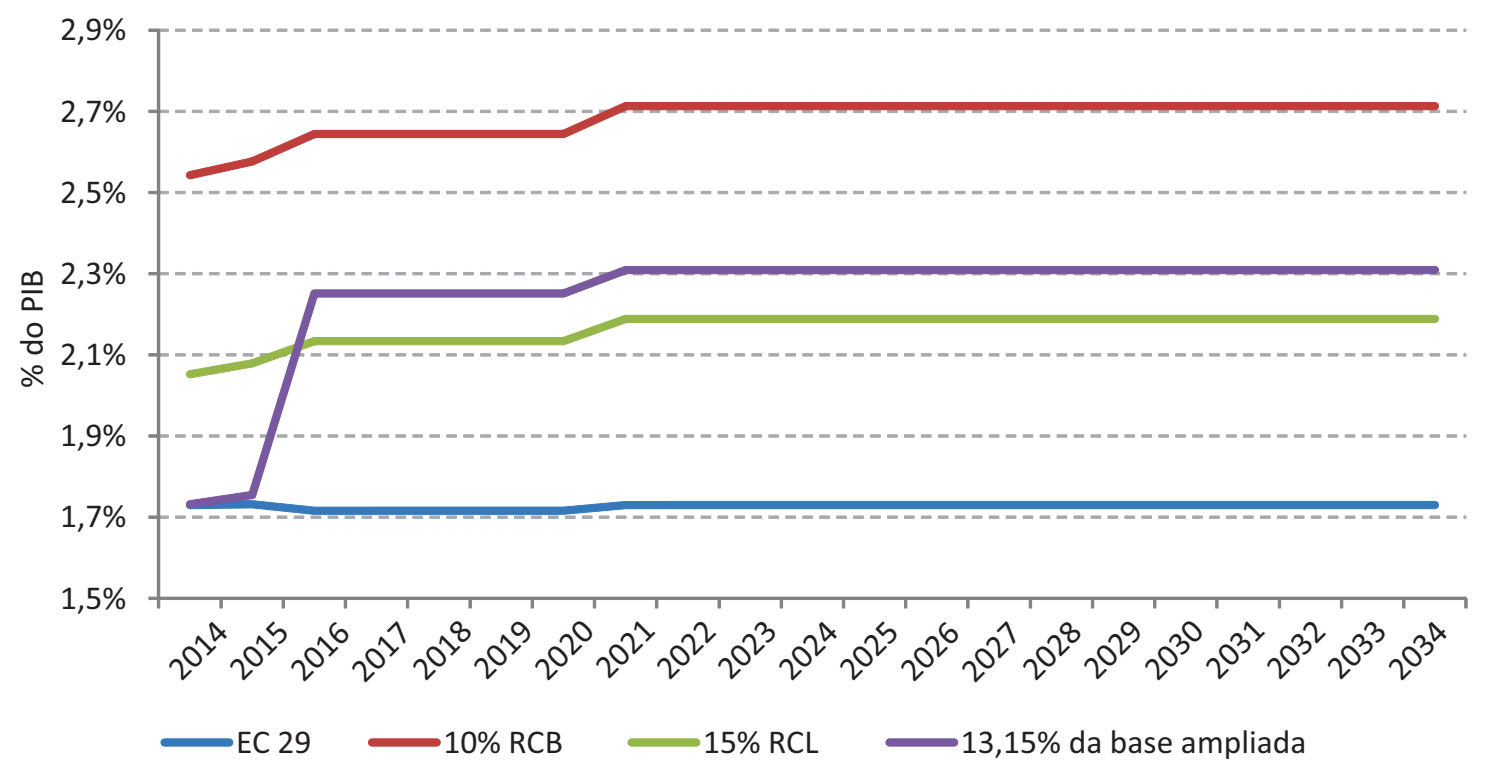

Fonte: elaboração dos autores com base em Bacen (2014) e LCA Consultoria (2013).

Gráfico 12 - Projeção dos gastos da União com ASPS sob diversos critérios, cenário adverso - 2014-2034

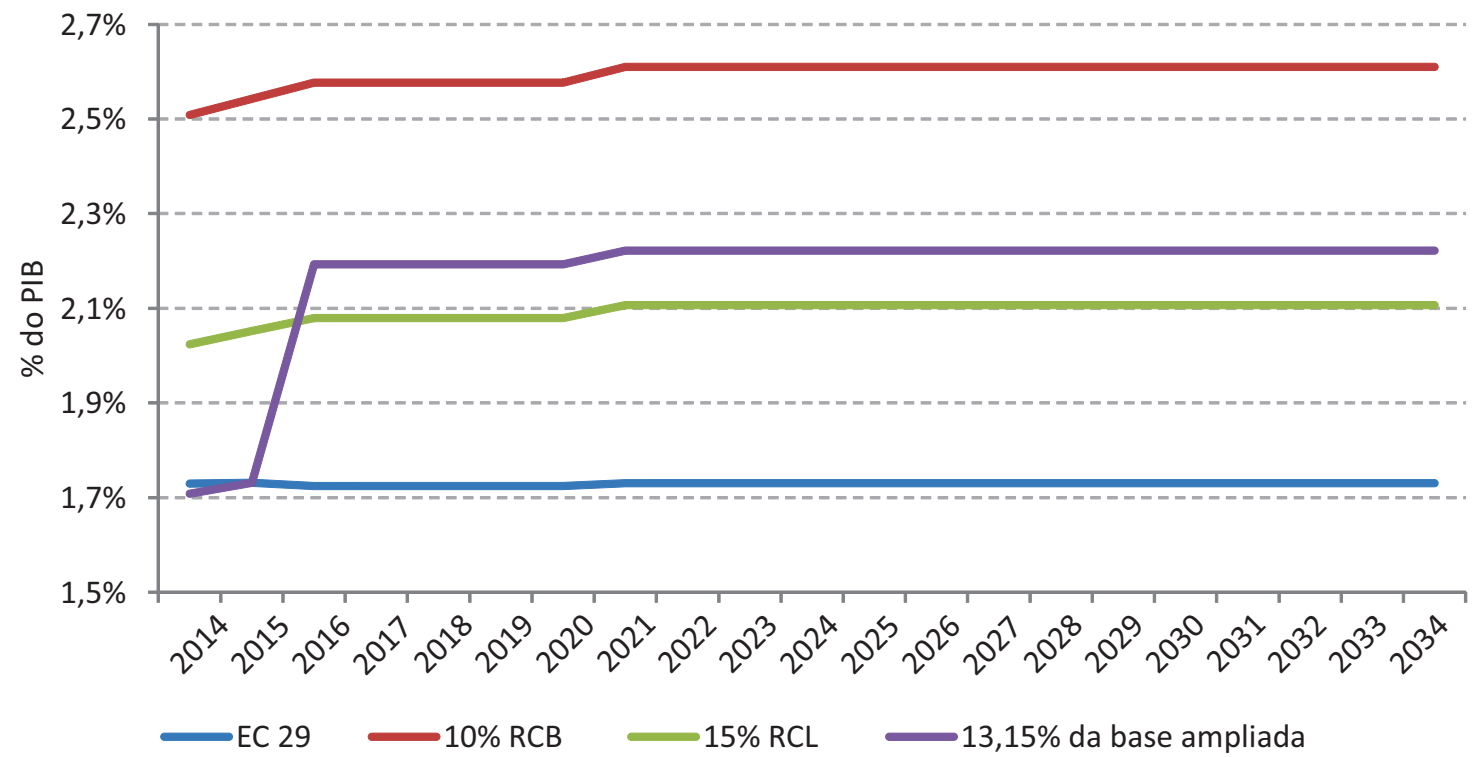

Fonte: elaboração dos autores com base em Bacen (2014) e LCA Consultoria (2013). 
A simples mudança de cenário não é suficiente para que se perceba uma mudança significativa em termos de volume de gastos com saúde. Com efeito, a maior diferença entre os dois cenários ocorre no critério de $10 \%$ da RCB e é de apenas 0,1\% do PIB em 2034. Em termos de tendência de crescimento não há qualquer diferença entre os dois casos.

Entretanto, algumas conclusões podem ser tiradas com base na análise dos gráficos 10 a 12 e seus dados de origem:

- o cumprimento estrito da EC n. 29 não proporciona ganhos de gasto em \% do PIB a longo prazo;

- a base RCB é a melhor, não apenas por proporcionar maior gasto a curto prazo como por apresentar a maior evolução em \% do PIB a longo prazo;

- a segunda melhor é a base ampliada da proposta de Dornelles; entretanto, essa proposta traz implicações federativas que interferem nos critérios de alocação de recursos própria da saúde

- se a DRU deixar de ser cobrada a partir de 2016, o gasto em saúde do governo federal a partir dessa proposta passaria de 1,73\% do PIB, em 2015, para 2,19\% do PIB, em 2016;

- considerando o fim da DRU, a base Dornelles seria a melhor a longo prazo por proporcionar um incremento de 0,49\% do PIB no gasto com ASPS da União;

- os dados apresentam o gasto mínimo em cada um dos critérios, não significando necessariamente que eles seriam cumpridos ou que ficariam apenas no mínimo;

- independentemente do nível do gasto e sua evolução, é patente que a utilização de uma vinculação de despesa baseada em um conceito de receita é melhor para o setor do que a vinculação baseada na evolução nominal do PIB.

Todas essas conclusões devem ser vistas com cautela, dadas as limitações das projeções apontadas anteriormente. A própria evolução da CTB pode ser relativizada, considerando que a experiência recente no Brasil tem mostrado um crescimento quase permanente, ano após ano, no tamanho da cunha tributária. Se o crescimento da CTB entre 2003 e 2013 (4,6\% do PIB) fosse mantido até 2034, poderíamos chegar a um patamar de carga da ordem de 46,6\% do PIB (equivalente à carga tributária dos países nórdicos), ao contrário da carga de 40\% do PIB projetada no cenário-base.

Se isso de fato ocorresse, certamente o espaço fiscal disponível para gastos sociais poderia ser bem maior, e também mais elevadas as despesas em ASPS. O que deve ser questionado, nesse caso, é se a economia e a sociedade brasileiras suportariam uma carga tributária maior do que $40 \%$ do PIB (equivalente à carga tributária dos países europeus da Organização para a Cooperação e Desenvolvimento Econômico - OCDE).

De qualquer forma, a expectativa de crescimento dos gastos com saúde - com a necessária elevação da participação dos gastos públicos na proporção do gasto total - é bastante plausível, não apenas devido ao crescimento da economia e da carga tributária. As projeções indicam um menor volume de endividamento, o que requereria um menor esforço fiscal por parte do governo (menos gastos com juros e encargos da dívida e menos necessidade de superávit primário). Isso, por si só, contribui significativamente para que haja maior espaço no orçamento e, consequentemente, para maior volume de despesas na área. 


\section{Síntese das Propostas}

A Tabela 19 apresenta um resumo das propostas e simulações de vinculação de recursos para a saúde apresentadas ao longo deste capítulo.

Tabela 19 - Síntese das propostas de destinação de recursos para a saúde

\begin{tabular}{|c|c|c|c|c|}
\hline $\begin{array}{l}\text { Modelo de destinação } \\
\text { de recursos para a saúde }\end{array}$ & Critério utilizado & $\begin{array}{l}\text { Gasto estimado em } \\
2013 \text { (R\$ milhões) }\end{array}$ & $\begin{array}{l}\Delta \text { em relação ao gasto } \\
\text { efetivo de } 2013 \text { (R\$ } \\
\text { milhões) }\end{array}$ & $\Delta \%$ \\
\hline EC n. 29 & $\Delta \%$ do PIB & 84.696 & 1.642 & $1,98 \%$ \\
\hline PLP n. 01/2003 & $10 \%$ da RCB & 121.965 & 38.911 & $46,85 \%$ \\
\hline $\begin{array}{l}\text { PEC Orçamento } \\
\text { Impositivo }\end{array}$ & $15 \%$ da RCL & 98.414 & 15.361 & $18,50 \%$ \\
\hline $\begin{array}{c}\text { PEC Orçamento } \\
\text { Impositivo + Emenda } \\
\text { Lucena }\end{array}$ & $18 \%$ da RCL & 118.097 & 35.044 & $42,19 \%$ \\
\hline CSS & $\begin{array}{c}\text { adicional de } 80 \% \text { da } \\
\text { CSS }\end{array}$ & 102.253 & 19.200 & $23,12 \%$ \\
\hline Royalties do petróleo & $\begin{array}{l}\text { adicional de } 25 \% \text { dos } \\
\text { Royalties }\end{array}$ & 84.576 & 1.523 & $1,83 \%$ \\
\hline $\begin{array}{l}\text { Reforma tributária } \\
\text { Dornelles }\end{array}$ & $\begin{array}{l}13,15 \% \text { da base } \\
\text { abrangente }\end{array}$ & 83.053 & 0 & $0,00 \%$ \\
\hline
\end{tabular}

Notas: 1) A alíquota utilizada na reforma tributária Dornelles foi estimada para que o resultado final fosse idêntico ao do gasto efetivo de 2013. Dessa forma, em um primeiro momento essa proposta não teria impacto em termos de orçamento.

2) A "base abrangente" da reforma tributária Dornelles é produto total da arrecadação de impostos e contribuições, exceto as de melhoria e destinadas ao custeio de benefícios previdenciários.

3) Inicialmente nem todos os recursos de royalties do petróleo são destinados para a saúde, mas apenas aqueles oriundos de poços com declaração de comercialidade ocorrida a partir de 3 de dezembro de 2012, no caso da União, e com contratos celebrados a partir de 3 de dezembro de 2012, no caso de estados e municípios.

Fonte: elaboração dos autores.

Em um cenário ideal para a saúde pública no Brasil seria necessário ter um aumento significativo na participação do setor público em saúde - por exemplo, um crescimento de $50 \%$ sobre a composição atual. Assim, a pergunta que fica é a seguinte: qual das alternativas apontadas anteriormente, ou que combinação delas, atenderia melhor as necessidades do SUS?

O crescimento das despesas com ASPS teria um crescimento satisfatório apenas com a proposta da PLP n. 01/2003 (10\% da RCB), que proporcionaria um aumento de quase 47\% nos recursos da pasta. A proposta que foi aprovada (PEC do Orçamento Impositivo) e já vigora por meio da EC n. 86, apresentaria um crescimento (18,5\%), porém muito brando e que poderia ser complementado pela CSS, que encontra grande resistência e só teria viabilidade em um cenário radical de reforma tributária. A emenda Lucena à PEC do Orçamento Impositivo também poderia proporcionar um ganho substancial (mais de 42\%) para o setor. As demais opções não apresentam, na prática, melhoras a curto prazo. 
Não foram consideradas propostas meritórias, como a da regulamentação da tributação sobre grandes fortunas, ou a ampliação da tributação sobre bebidas e fumo. Em primeiro lugar por seu pequeno impacto potencial sobre a arrecadação; em segundo lugar, por não querer transferir à área da saúde a responsabilidade exclusiva pela elevação da cunha tributária, na presença indiscutível de alternativas de maior produtividade e potencial de criação de espaço fiscal.

Independentemente do que vier a ocorrer com a forma de financiamento da saúde no Brasil nos próximos anos, é necessário ter em mente os problemas intrínsecos ao setor público quando o assunto é gasto e destinação de recursos. A aprovação de uma maior vinculação de receitas para o setor não significaria necessariamente, na prática, a alocação de mais recursos para a saúde.

Se as despesas obrigatórias da União crescem, os recursos livres (transferências voluntárias do SUS) que financiam grande parte dos gastos locais poderiam diminuir na mesma proporção. A diferença, nesse caso, seria que o governo central passaria a concentrar mais os gastos com saúde, o que não é obrigatoriamente interessante para a necessária convergência federativa da política setorial.

Dessa forma, é necessário avaliar não apenas as formas de financiamento da saúde. Além de assegurar um maior fluxo de receitas, quem deseja que a saúde tenha de fato um impulso sustentado de crescimento, deve-se preocupar em assegurar que o gasto total do setor público em ASPS (não apenas da União, mas dos demais entes federados) seja efetivamente ampliado e repassado integralmente ao setor.

\section{Referências}

AGÊNCIA NACIONAL DO PETRÓLEO (ANP). Consolidação das participações governamentais e de terceiros. Disponível em: <www.anp.gov.br/?id=522> . Acesso em: 5 fev. 2014.

BANCO CENTRAL DO BRASIL (BACEN). Relatório de Mercado sobre os Principais Indicadores Econômicos Brasileiros. Brasília: Gerin, Bacen, 2014. (Boletim Focus).

BRASIL. Secretaria de Assuntos Estratégicos. Redução das Desigualdades e Melhoria da Qualidade do Sistema de Saúde no Brasil. Brasília: SAE, 2009.

BRASIL. Câmara dos Deputados. Projeto de lei n. 323, de 2007. Comissão especial destinada a proferir parecer ao projeto de lei n. 323 de 2007. Brasília, Diário Oficial da União, 2013a.

BRASIL. Câmara dos Deputados. Projeto de lei n. 41, de 2013. Parecer ao substitutivo do Senado ao projeto de lei da Câmara n. 41 de 2013 (n. 323 de 2007). Brasília, Diário Oficial da União, 2013b.

BRASIL. Câmara dos Deputados. Relatório da comissão especial destinada a discutir o financiamento da saúde pública. Brasília, DF, 2013. Diário Oficial da União, Brasília, 16 out. 2013c.

BRASIL. Câmara dos Deputados. Destinação para as áreas de educação e saúde de parcela da participação no resultado ou da compensação financeira pela exploração de petróleo e gás natural. Nota Técnica n. 14/2013. Brasília: COFF, 2013d.

BRASIL. Ministério da Fazenda. Receita Federal. Subsecretaria de Tributação e Contencioso. Demonstrativo dos gastos tributários: estimativas bases efetivas - 2010. Série 2008 a 2012. Brasília: MF, Coget, RFB, 2013e. Disponível em: <https://idg.receita.fazenda.gov.br/dados/receitadata/renuncia-fiscal/demonstrativos-dosgastos-tributarios/arquivos-e-imagens/ano-calendario-2010-serie-2008-a-2012> . 
BRASIL. Ministério da Fazenda. Receita Federal. Subsecretaria de Tributação e Contencioso. Análise da Arrecadação das Receitas Federais: dezembro 2013. Brasília: MF, Coget, RFB, 2013f.

BRASIL. Ministério de Minas e Energia. Nota Sobre o Pré-Sal e o Campo de Libra. Brasília: MME, 2013g.

BRASIL. Secretaria de Política Econômica. Demonstrativo de Benefícios Financeiros e Creditícios. Brasília: SPE, 2013h.

BRASIL. Ministério da Saúde. Demonstrativos. Disponível em: <http://portalsaude.saude.gov.br/index.php/ o-ministerio/principal/siops/mais-sobre-siops/6008-demonstrativos>. Acesso em: 9 mar. 2014a.

BRASIL. Ministério do Trabalho e Previdência Social. Site. Disponível em: <www.mtps.gov.br/dados-abertos/ dados-da-previdencia/previdencia-social-e-inss > . Acesso em: 3 mar. 2014b.

CAIXA ECONÔMICA FEDERAL (CEF). Site. Disponível em: <www.fgts.gov.br/downloads.asp>. Acesso em: 3 mar. 2014.

DAIN, S. Os vários mundos do financiamento da saúde no Brasil: uma tentativa de integração. Ciência \& Saúde Coletiva, 12: 1.851-1.864, 2007.

DAIN, S. Bases institucionais e financeiras da seguridade social no Brasil. In: LOBATO, L. V. C. \& FLEURY, S. (Orgs.). Seguridade Social, Cidadania e Saúde. Rio de Janeiro: Cebes, 2009. (Coleção Pensar em Saúde).

DAIN, S. \& CASTRO, K. Propostas de Criação da CSS: alternativas para o financiamento da saúde nos anos 2000. Rio de Janeiro: MS, Opas, 2008.

DINIZ, É. \& AFONSO, J. R. Benefícios Fiscais Concedidos (e Mensurados) pelo Governo Federal. Rio de Janeiro: FGV, 2014. (Texto para discussão).

DORNELLES, F. Proposta de Sistema Tributário. Brasília: Senado Federal, 2010.

EMPRESA DE PESQUISA ENERGÉTICA (EPE). Plano Decenal de Expansão de Energia 2022. Rio de Janeiro: EPE, 2013.

FUNDO MONETÁRIO INTERNACIONAL (FMI). Fiscal monitor taxing times, out. 2013. Disponível em: <www. imf.org/external/pubs/ft/fm/2013/02/pdf/fm1302.pdf>. Acesso em: 8 nov. 2013.

GADELHA, P; CARVALHO, J. N. \& PEREIRA, T. R. (Orgs.). A Saúde no Brasil em 2030: diretrizes para a prospecção estratégica do sistema de saúde brasileiro. Rio de Janeiro: Fiocruz, Ipea, Ministério da Saúde, Secretaria de Assuntos Estratégicos da Presidência da República, 2012.

INSTITUTO BRASILEIRO DE GEOGRAFIA E ESTATÍSTICA (IBGE). Sistema de Contas Nacionais - Brasil 20102013, referência 2010. Disponível em: <www.ibge.gov.br/home/estatistica/economia/contasnacionais/2013/ default.shtm>. Acesso em: 3 mar. 2014.

INSTITUTO BRASILEIRO DE GEOGRAFIA E ESTATÍSTICA (IBGE). Estimativas populacionais para os municípios brasileiros em 01.07.2012. Disponível em: <www.ibge.gov.br/home/estatistica/populacao/estimativa2012/ default.shtm>. Acesso em: jun. 2016.

INSTITUTO DE PESQUISA ECONÔMICA APLICADA (IPEA). Equidade fiscal no Brasil: impactos distributivos da tributação e do gasto Social. Comunicados do Ipea, 92: 3-25, 2011.

INTERNATIONAL ENERGY AGENCY (IEA). Brazilian resources and supply potential. In: INTERNATIONAL ENERGY AGENCY (IEA). World Energy Outlook 2013. Paris: OECD, IEA, 2013.

LCA CONSULTORIA. Relatório de Longo Prazo LCA: cenários macroeconômicos de longo prazo 2013-2030. São Paulo: LCA Consultores, 2013.

LIMA, P. C. R. Receitas Petrolíferas para as Áreas de Educação e Saúde. Brasília: Câmara dos Deputados, 2013a. Disponível em: <http://darcisioperondi.com.br/wp-content/uploads/2013/07/Nota-T\%C3\%A9cnica-sobrereceitas-petrol\%C3\%ADferas-para-as-\%C3\%A1reas-de-educa\%C3\%A7\%C3\%A3o-e-sa\%C3\%BAde-Senado. pdf > . Acesso em: maio 2016. 
LIMA, P. C. R. Nota Técnica Preliminar após o "Leilão" de Libra. Brasília: [s.n.], 2013b.

LOSEKANN, L. \& PERIARD, T. Projeções do pré-sal: o Brasil será um petroestado?. Blog Infopetro, 2013. Disponível em: < https://infopetro.wordpress.com/2013/05/20/projecoes-do-pre-sal-o-brasil-sera-um-petro-estado>. Acesso em: 7 jan. 2014.

OCKÉ-REIS, C. O. Mensuração dos Gastos Tributários: o caso dos planos de saúde - 2003/2011. Brasília: Ipea, 2013. (Nota técnica do Ipea n. 5).

PAIM, J. et al. O sistema de saúde brasileiro: história, avanços e desafios. The Lancet, 377(9.779): 1.778-1.797, 2011. (Série Saúde no Brasil 1).

PIOLA, S. F. Financiamento da saúde no Brasil hoje e suas perspectivas para o futuro. In: CICLO DE SIMPÓSIOS SOBRE SAÚDE PÚBLICA, 1, abr. 2014, São Paulo.

PIOLA, S. F. et al. Financiamento Público da Saúde: uma história à procura de rumo. Rio de Janeiro: Ipea, 2013. (Texto para discussão do Ipea n. 1.846).

PRICE WATERHOUSE COOPERS (PWC). Alberta's Royalty System: jurisdictional comparison. São Paulo: PWC, 2009.

QUINTAS, H. "Unitização": a perspectiva petrolífera. In: CONGRESSO INTERNACIONAL DE DIREITO MINERÁRIO, 1, 2010, Salvador. Slides... Salvador: IBP, 2010.

RECEITA FEDERAL DO BRASIL (RFB). Disponível em: < http://idg.receita.fazenda.gov.br/dados/receitadata/ arrecadacao/relatorios-do-resultado-da-arrecadacao > . Acesso em: 3 mar. 2014.

SECRETARIA DO TESOURO NACIONAL (STN). Relatório resumido de execução orçamentária. Disponível em: $<$ www.tesouro.fazenda.gov.br/-/relatorio-resumido-de-execucao-orcamentaria >. Acesso em: 3 mar. 2014.

SILVEIRA, F. G. Equidade Fiscal: impactos distributivos da tributação e do gasto social. Brasília: Esaf, TN, 2012.

SILVEIRA, F. G. et al. Fiscal Equity: distributional impacts of taxation and social spending in Brazil. Brasília: International Policy Centre for Inclusive Growth, 2013. (Working paper 115).

TEIXEIRA, A. \& VIANNA, S. W. Cenários macroeconômicos no horizonte 2022/2030. Disponível em: < https:// saudeamanha.fiocruz.br/sites/saudeamanha.fiocruz.br/files/publicacoes/ASaudeNoBrasilEm2030_V1_ Cenarios_Macroeconomicos_no_Horizonte_2022-2030.pdf>. Acesso em: jun. 2016.

TRIBUNAL DE CONTAS DA UNIÃO (TCU). Transferências constitucionais e legais. Disponível em: < http://portal. tcu.gov.br/comunidades/transferencias-constitucionais-e-legais/coeficientes-fpe-e-fpm>. Acesso em: 5 fev. 2014.

VIOL, A. L. et al. CPMF: mitos e verdades sob as óticas econômica e administrativa. Brasília: Coordenação Geral de Política Tributária, Coordenação de Estudos Econômicos, 2001. (Texto para discussão n. 15).

WORLD HEALTH ORGANIZATION (WHO). The World Health Report 2006: working together for health. Geneva: WHO, 2006.

WORLD HEALTH ORGANIZATION (WHO). The World Health Report 2010: health systems financing - the path to universal coverage. Geneva: WHO, 2010.

WORLD HEALTH ORGANIZATION (WHO). World Health Statistics 2013 - Part III: global health indicators. Geneva: WHO, 2013.

ZANGHELINI, A. N. et al. Desoneração da folha de pagamento: oportunidade ou ameaça? Brasília: Anfip, 2013. Disponível em: <www.anfip.org.br/publicacoes/20131212170948_Desoneracao-da-Folha-de-PagamentosOportunidade-ou-Ameaca_12-12-2013_LivroDesonerao.pdf $>$. 


\section{ANEXO}

Tabela 20 - Simulação de gastos com ASPS na EC n. 29 com Contribuição Social para a Saúde, em milhões correntes

\begin{tabular}{|c|c|c|c|c|c|c|c|}
\hline Ano & $\begin{array}{c}\text { Gastos } \\
\text { efetivos com } \\
\text { ASPS }\end{array}$ & PIB nominal & $\begin{array}{l}\text { Var. nominal } \\
\text { PIB do ano } \\
\text { anterior }\end{array}$ & $\begin{array}{c}\text { Gasto } \\
\text { segundo a } \\
\text { EC n. } 29 \\
(\Delta \text { PIB })\end{array}$ & $\begin{array}{l}\text { Gasto segundo } \\
\text { a EC n. } 29 \\
(\Delta \text { PIB })+C S S \\
\text { (a partir de } \\
2008)\end{array}$ & $\begin{array}{c}\text { Diferença } \\
\text { para gasto } \\
\text { efetivo }\end{array}$ & $\begin{array}{l}\text { Diferença } \\
\text { acumulada }\end{array}$ \\
\hline 1999 & 18.353 & 1.065 .000 & - & 18.353 & 18.353 & 0 & 0 \\
\hline 2000 & 20.351 & 1.179 .482 & $5,00 \%$ & 19.271 & 19.271 & 1.081 & 1.081 \\
\hline 2001 & 22.474 & 1.302 .136 & $10,75 \%$ & 22.539 & 22.539 & -65 & 1.016 \\
\hline 2002 & 24.737 & 1.477 .822 & $10,40 \%$ & 24.883 & 24.883 & -146 & 870 \\
\hline 2003 & 27.181 & 1.699 .948 & $13,49 \%$ & 28.240 & 28.240 & -1.059 & -190 \\
\hline 2004 & 32.703 & 1.941 .498 & $15,03 \%$ & 32.485 & 32.485 & 219 & 29 \\
\hline 2005 & 37.146 & 2.147 .239 & $14,21 \%$ & 37.350 & 37.350 & -205 & -176 \\
\hline 2006 & 40.750 & 2.369 .484 & $10,60 \%$ & 41.308 & 41.308 & -558 & -734 \\
\hline 2007 & 44.303 & 2.661 .344 & $10,35 \%$ & 45.584 & 45.584 & -1.280 & -2.014 \\
\hline 2008 & 48.670 & 3.032 .203 & $12,32 \%$ & 51.199 & 59.199 & -10.529 & -12.543 \\
\hline 2009 & 58.270 & 3.239 .404 & $13,94 \%$ & 58.333 & 68.573 & -10.303 & -22.846 \\
\hline 2010 & 61.965 & 3.770 .085 & $6,83 \%$ & 62.319 & 74.799 & -12.834 & -35.680 \\
\hline 2011 & 72.357 & 4.143 .013 & $16,38 \%$ & 72.529 & 87.249 & -14.892 & -50.572 \\
\hline 2012 & 78.211 & 4.402 .537 & $9,89 \%$ & 79.703 & 96.663 & -18.452 & -69.025 \\
\hline 2013 & 83.053 & 4.806 .925 & $6,26 \%$ & 84.696 & 103.896 & -20.842 & -89.867 \\
\hline
\end{tabular}

Fonte: elaboração dos autores com base em IBGE (2014), STN (2014) e RFB (2014). 
Tabela 21 - Simulação de gastos com ASPS na PLP 01/2003 com Contribuição Social para a Saúde, em milhões correntes

\begin{tabular}{|l|l|l|c|c|c|}
\hline Ano & $\begin{array}{c}\text { Gastos efetivos } \\
\text { com ASPS }\end{array}$ & $\begin{array}{c}\text { Receita Corrente } \\
\text { Bruta da União }\end{array}$ & $\begin{array}{c}\text { Gasto segundo a } \\
\text { PL RCB) + CSS } \\
\text { da partir de 2008) }\end{array}$ & $\begin{array}{c}\text { Diferença para } \\
\text { gasto efetivo }\end{array}$ & $\begin{array}{c}\text { Diferença } \\
\text { acumulada }\end{array}$ \\
\hline 1999 & 18.353 & 0 & 0 & 0 & -4.900 \\
\hline 2000 & 20.351 & 252.519 & $2525185,04 \%$ & -4.900 & -11.367 \\
\hline 2001 & 22.474 & 289.411 & $2894109,18 \%$ & -6.467 & -20.938 \\
\hline 2002 & 24.737 & 343.075 & $3430749,88 \%$ & -9.571 & -32.202 \\
\hline 2003 & 27.181 & 384.447 & $3844470,11 \%$ & -11.264 & -44.557 \\
\hline 2004 & 32.703 & 450.590 & $4505899,81 \%$ & -12.356 & -60.144 \\
\hline 2005 & 37.146 & 527.325 & $5273245,78 \%$ & -15.587 & -77.800 \\
\hline 2006 & 40.750 & 584.067 & $5840674,71 \%$ & -17.657 & -99.385 \\
\hline 2007 & 44.303 & 658.884 & $6588844,17 \%$ & -21.585 & -134.189 \\
\hline 2008 & 48.670 & 754.736 & $8347355,17 \%$ & -34.803 & -163.699 \\
\hline 2010 & 58.270 & 775.407 & $8778067,59 \%$ & -29.510 & -203.228 \\
\hline 2011 & 72.965 & 890.137 & $10149370,33 \%$ & -39.529 & -248.552 \\
\hline 2012 & 78.211 & 1.134 .717 & $13043173,35 \%$ & -52.221 & -300.773 \\
\hline 2013 & 83.053 & 1.219 .646 & $14116458,09 \%$ & -58.111 & -358.885 \\
\hline & & & & & 0 \\
\hline
\end{tabular}

Fonte: elaboração dos autores com base em IBGE (2014), STN (2014) e RFB (2014). 
Tabela 22 - Simulação de gastos com ASPS na PEC Orçamento Impositivo com Contribuição Social para a Saúde, em milhões correntes

\begin{tabular}{|l|l|c|c|c|c|}
\hline Ano & $\begin{array}{c}\text { Gastos efetivos } \\
\text { com ASPS }\end{array}$ & $\begin{array}{c}\text { Receita Corrente } \\
\text { Líquida da União }\end{array}$ & $\begin{array}{c}\text { Gasto segundo a PEC } \\
\text { Orçamento Impositivo } \\
\left(\begin{array}{c}15 \% \text { da RCL }+ \text { CSS } \\
\text { (a partir de 2008) }\end{array}\right.\end{array}$ & $\begin{array}{c}\text { Diferença para } \\
\text { gasto efetivo }\end{array}$ & $\begin{array}{c}\text { Diferença } \\
\text { acumulada }\end{array}$ \\
\hline 1999 & 18.353 & 0 & 0 & 0 & 0 \\
\hline 2000 & 20.351 & 145.111 & $2176659,75 \%$ & -1.415 & -1.415 \\
\hline 2001 & 22.474 & 167.739 & $2516086,53 \%$ & -2.687 & -4.102 \\
\hline 2002 & 24.737 & 201.927 & $3028909,80 \%$ & -5.552 & -9.654 \\
\hline 2003 & 27.181 & 224.920 & $3373802,46 \%$ & -6.557 & -16.211 \\
\hline 2004 & 32.703 & 264.353 & $3965294,97 \%$ & -6.949 & -23.160 \\
\hline 2005 & 37.146 & 303.016 & $4545236,63 \%$ & -8.307 & -31.467 \\
\hline 2006 & 40.750 & 344.731 & $5170971,50 \%$ & -10.960 & -42.427 \\
\hline 2007 & 44.303 & 386.682 & $5800227,86 \%$ & -13.699 & -56.125 \\
\hline 2008 & 48.670 & 428.563 & $7228449,32 \%$ & -23.614 & -79.740 \\
\hline 2009 & 58.270 & 437.199 & $7581991,32 \%$ & -17.550 & -97.289 \\
\hline 2010 & 61.965 & 499.867 & $8745999,20 \%$ & -25.495 & -122.784 \\
\hline 2011 & 72.357 & 558.706 & $9852595,81 \%$ & -26.169 & -148.953 \\
\hline 2012 & 78.211 & 616.933 & $10950000,24 \%$ & -31.289 & -180.243 \\
\hline 2013 & 83.053 & 656.094 & $11761413,27 \%$ & -34.561 & -214.804 \\
\hline & & & & & \\
\hline
\end{tabular}

Fonte: elaboração dos autores com base em IBGE (2014), STN (2014) e RFB (2014). 
Tabela 23 - Estimativa de arrecadação tributária e de recursos destinados à Seguridade Social com Contribuição Social para a Saúde, de acordo com a PEC 233/2008

\begin{tabular}{|c|c|c|}
\hline \multirow{3}{*}{ União } & \multirow{2}{*}{$\begin{array}{c}\text { \% do PIB } \\
\text { Carga tributária estimada }\end{array}$} & \multirow{2}{*}{$\begin{array}{c}\mathrm{R} \$ \text { milhões } \\
\text { Arrecadação estimada }\end{array}$} \\
\hline & & \\
\hline & $25,54 \%$ & 1.227 .672 \\
\hline ORÇAMENTO FISCAL & $8,62 \%$ & 414.218 \\
\hline IR & $6,09 \%$ & 292.810 \\
\hline Pessoa física & $0,55 \%$ & 26.452 \\
\hline Pessoa jurídica & $2,62 \%$ & 126.149 \\
\hline Retido na fonte & $2,92 \%$ & 140.209 \\
\hline IPI & $0,98 \%$ & 47.101 \\
\hline IOF & $0,61 \%$ & 29.415 \\
\hline Imp. sobre comércio exterior & $0,77 \%$ & 37.197 \\
\hline ITR & $0,02 \%$ & 848 \\
\hline Taxas federais & $0,14 \%$ & 6.848 \\
\hline OrÇamento SEguridade & $14,06 \%$ & 675.676 \\
\hline Previdência social & $6,22 \%$ & 299.080 \\
\hline Cofins & $4,19 \%$ & 201.527 \\
\hline CSS & $0,50 \%$ & 24.000 \\
\hline CSLL & $1,37 \%$ & 65.732 \\
\hline PIS & $1,08 \%$ & 51.899 \\
\hline Contr. segur. servidor público & $0,51 \%$ & 24.580 \\
\hline Outras contr. sociais & $0,18 \%$ & 8.859 \\
\hline DEMAIS & $2,87 \%$ & 137.778 \\
\hline FGTS & $1,89 \%$ & 90.624 \\
\hline Cide & $0,00 \%$ & 35 \\
\hline Outras contr. econômicas & $0,36 \%$ & 17.099 \\
\hline Salário-eduação & $0,34 \%$ & 16.561 \\
\hline Sistema S & $0,28 \%$ & 13.459 \\
\hline PIB estimado & & 4.806 .925 \\
\hline Recursos da Seguridade Socia & PEC 233/2008 & 228.926 \\
\hline $38,8 \%$ do IVA (Cofins + PIS + & de + Salário-educação) & 83.814 \\
\hline 38,8\% do IR (IR + CSLL) & & 111.291 \\
\hline $38,8 \%$ do IPI & & 14.620 \\
\hline
\end{tabular}

Fonte: elaboração dos autores com base em Bacen (2004), IBGE (2014) e RFB (2014). 
Tabela 24 - Estimativa de arrecadação tributária e de recursos destinados à Seguridade Social com Contribuição Social para a Saúde, de acordo com a proposta de Francisco Dornelles - 2013

\begin{tabular}{|c|c|c|}
\hline & $\%$ do PIB & $\mathrm{R} \$$ milhões \\
\hline & Carga tributária estimada & Arrecadação estimada \\
\hline União & $25,54 \%$ & 1.227 .672 \\
\hline ORÇAMENTO FISCAL & $8,62 \%$ & 414.218 \\
\hline IR & $6,09 \%$ & 292.810 \\
\hline Pessoa física & $0,55 \%$ & 26.452 \\
\hline Pessoa jurídica & $2,62 \%$ & 126.149 \\
\hline Retido na fonte & $2,92 \%$ & 140.209 \\
\hline IPI & $0,98 \%$ & 47.101 \\
\hline IOF & $0,61 \%$ & 29.415 \\
\hline Imp. sobre comércio exterior & $0,77 \%$ & 37.197 \\
\hline ITR & $0,02 \%$ & 848 \\
\hline Taxas federais & $0,14 \%$ & 6.848 \\
\hline ORÇAMENTO SEGURIDADE & $14,06 \%$ & 675.676 \\
\hline Previdência social & $6,22 \%$ & 299.080 \\
\hline Cofins & $4,19 \%$ & 201.527 \\
\hline CSS & $0,50 \%$ & 24.000 \\
\hline CSLL & $1,37 \%$ & 65.732 \\
\hline PIS/Pasep & $1,08 \%$ & 51.899 \\
\hline Contr. segur. servidor público & $0,51 \%$ & 24.580 \\
\hline Outras contr. sociais & $0,18 \%$ & 8.859 \\
\hline DEMAIS & $2,87 \%$ & 137.778 \\
\hline FGTS & $1,89 \%$ & 90.624 \\
\hline Cide & $0,00 \%$ & 35 \\
\hline Outras contr. econômicas & $0,36 \%$ & 17.099 \\
\hline Salário-eduação & $0,34 \%$ & 16.561 \\
\hline Sistema S & $0,28 \%$ & 13.459 \\
\hline PIB estimado & & 4.806 .925 \\
\hline Recursos da saúde (c/DRU) - & rancisco Dornelles & 102.253 \\
\hline $13,15 \%$ da base abrangente & & 83.053 \\
\hline CSS & & 19.200 \\
\hline
\end{tabular}

Nota: a base abrangente inclui imposto e contribuições, excluindo a previdência (conceito amplo) e as contribuições de melhoria.

Fonte: elaboração dos autores com base em Bacen (2004), IBGE (2014) e RFB (2014). 
Tabela 25 - Distribuição regional do petróleo, em R\$ milhões correntes - 2013

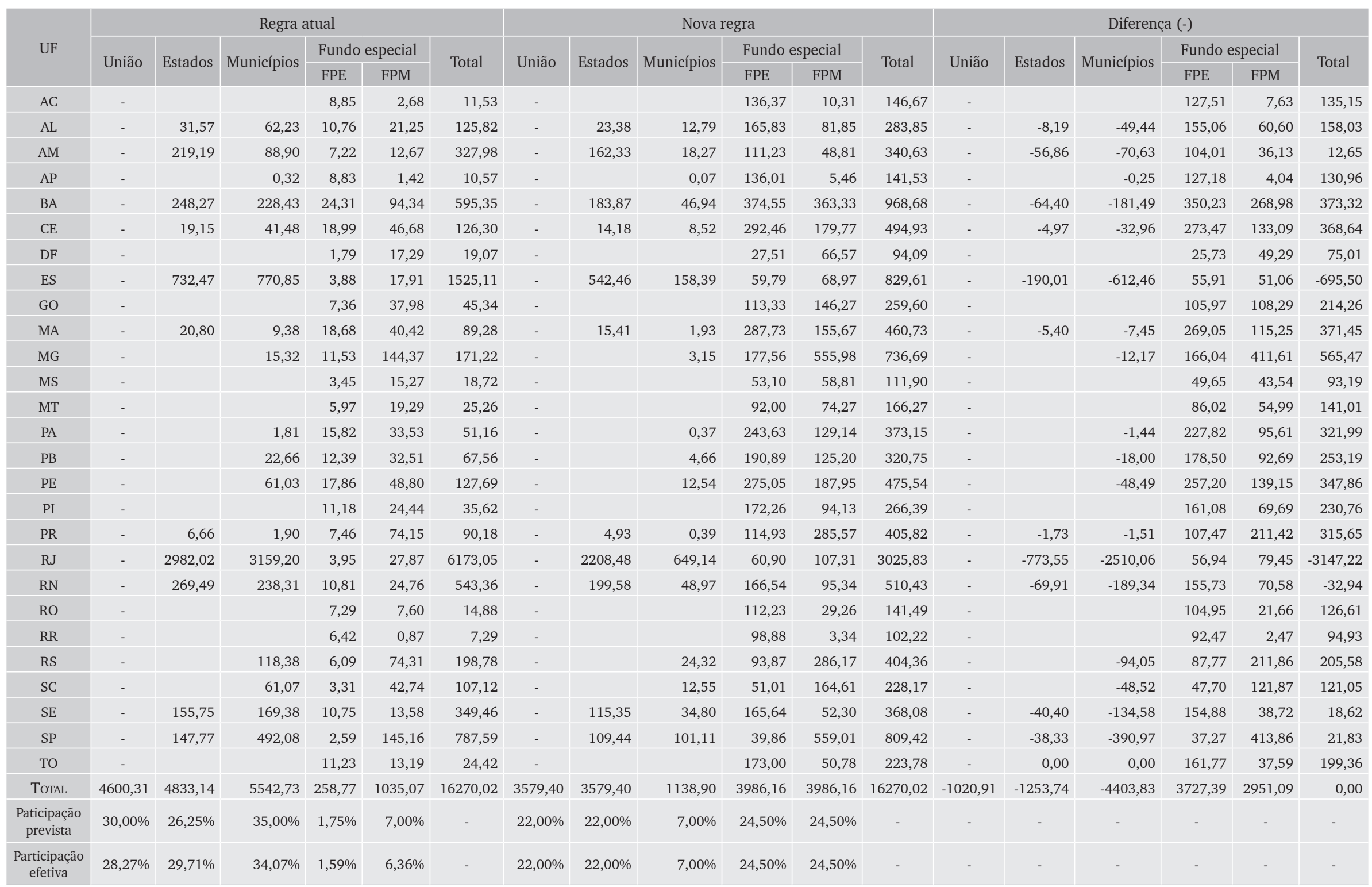

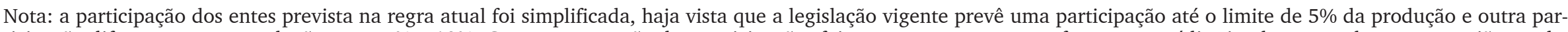

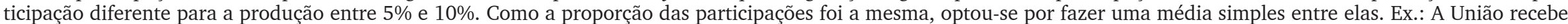
$20 \%$ dos royalties arrecadados até 5\% da produção e 40\% dos royalties arrecadados entre 5\% e 10\% da produção, logo, na média o ente recebe 30\%.

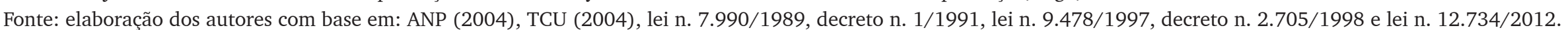





\title{
MUDANÇAS RECENTES NO SETOR PRIVADO DE SERVIÇOS DE SAÚDE NO BRASIL: INTERNACIONALIZAÇÃO E FINANCEIRIZAÇÃO
}

\author{
Célio Hiratuka \\ Marco Antonio Martins da Rocha \\ Fernando Sarti
}

\begin{abstract}
O setor de serviços de saúde tem passado por mudanças profundas no cenário mundial, assim como no Brasil. No contexto internacional, as estratégias dos grandes grupos empresariais do setor têm sido marcadas por fusões e aquisições crescentes, de modo a ganhar escala e enfrentar os custos decorrentes das mudanças regulatórias e da incorporação de equipamentos e tecnologias mais avançados. Em grande medida, os processos de capitalização realizada por fundos de private equity têm tido um papel relevante no financiamento do crescimento, participando ativamente de fusões e aquisições promovidas por esses grandes grupos.
\end{abstract}

Esse movimento tem transbordado para a economia brasileira, que vem passando também por uma intensificação no processo de fusões e aquisições, com crescente participação de atores internacionais. Da mesma maneira, a capitalização proporcionada por fundos de private equity no Brasil é uma das características mais importantes nas transformações recentes do setor. Nos próximos anos, esse processo deve continuar a ter impactos importantes sobre a abrangência e a qualidade dos serviços privados prestados, exigindo crescente atenção dos órgãos reguladores e dos formuladores de políticas públicas de saúde.

Com o objetivo de caracterizar tais transformações e permitir um melhor entendimento das transformações recentes ocorridas no setor privado de serviços de saúde no Brasil, este capítulo está estruturado em três seções. A primeira destaca o movimento geral de internacionalização da economia, resultado de um processo de maior interpenetração dos fluxos de comércio e investimento globais, porém acompanhado de movimento intenso de centralização do capital em nível mundial. Também ressalta como, depois de um início mais concentrado nas atividades industriais, a internacionalização vem atingindo crescentemente o setor de serviços. A segunda seção, além de traçar um perfil das maiores empresas globais do setor, concentra o foco no cenário internacional de serviços de saúde, detalhando os fatores que têm impulsionado o movimento de concentração no setor, assim como sua expansão internacional. A terceira seção analisa as transformações no mercado brasileiro, destacando a tendência de maior concentração no mercado, processo que tem sido impulsionado no período recente tanto pelo movimento de entrada de empresas estrangeiras, quanto pelo destacado interesse dos fundos de investimentos nesse segmento. 


\section{Caracterização da Internacionalização}

A economia mundial vem passando por um profundo processo de internacionalização nos últimos anos. Embora o aumento das transações econômicas internacionais não seja recente, a forma como ele ocorreu no chamado processo de globalização trouxe novidades importantes.

Em primeiro lugar, deve-se destacar a velocidade do processo. Observou-se um cenário onde o movimento de internacionalização se aprofundou enormemente, ao mesmo tempo que o mapa da produção, do comércio, dos investimentos, das finanças e do conhecimento tecnológico também passou por transformações relevantes.

Uma ilustração desse primeiro processo pode ser visto no Gráfico 1, em que é possível observar como, a partir da década de 1980, o aumento das exportações de bens em relação ao Produto Interno Bruto (PIB) mundial (medido no eixo esquerdo - E) passou a ser acompanhado também pela maior internacionalização dos serviços e dos investimentos diretos (eixo direito - D). No caso dos investimentos diretos estrangeiros (IDE), o fluxo registrado de entrada mundial equivalia a cerca de 0,5\% do PIB global em 1980; passou a apresentar crescimento expressivo ao longo da década e alcançou taxas de crescimento explosivas nos anos 1990, chegando a atingir 4\% em 2000. Posteriormente sofreu flutuações importantes, sentindo os impactos da crise da economia americana em 2001; recuperou-se a partir de 2003 até atingir o patamar recorde de 4,4\% em 2007 e sofreu novamente com a crise financeira global a partir de 2008.

A internacionalização começou a se verificar também nos serviços, uma área por muito tempo considerada como menos sujeita ao processo de transnacionalização. A relação entre exportações de serviços e o PIB mundial passou de cerca de 3,5\% na década de 1980 para pouco mais de 6\% em 2012.

Além da velocidade no processo de internacionalização, também se devem destacar as transformações na forma de concorrência. Na verdade, os dados apresentados no Gráfico 1 são os aspectos mais visíveis e superficiais das profundas mudanças que vêm ocorrendo na estrutura produtiva mundial, resultado da intensificação da concorrência entre as grandes empresas globais (Chesnais, 1996).

Desde a década de 1980, a gestão e a forma de operação internacional das grandes corporações vêm se transformando de maneira acentuada, consequência em grande parte das estratégias das corporações americanas, pressionadas pela competição acirrada levada a cabo por empresas da Europa Continental e do Japão. Ao mesmo tempo, a grande empresa americana encontrou-se pressionada também pelo crescente questionamento acerca da eficiência do modelo gerencial da grande corporação multidivisional diversificada. Para os críticos desse modelo, a autonomia exagerada dos gerentes para alocar os lucros acumulados havia criado corporações excessivamente diversificadas, com a implementação de projetos de investimentos que não necessariamente geravam retornos aos acionistas. Acionistas mais ativos, remunerações atreladas ao desempenho das ações e o movimento de fusões e aquisições hostis seriam as formas de disciplinar e implantar um novo modelo de gestão, mais alinhado com o interesse dos acionistas, nessas grandes corporações (Jensen, 1989). 
Gráfico 1 - Indicadores de internacionalização econômica selecionados, em \% - 1970-2012

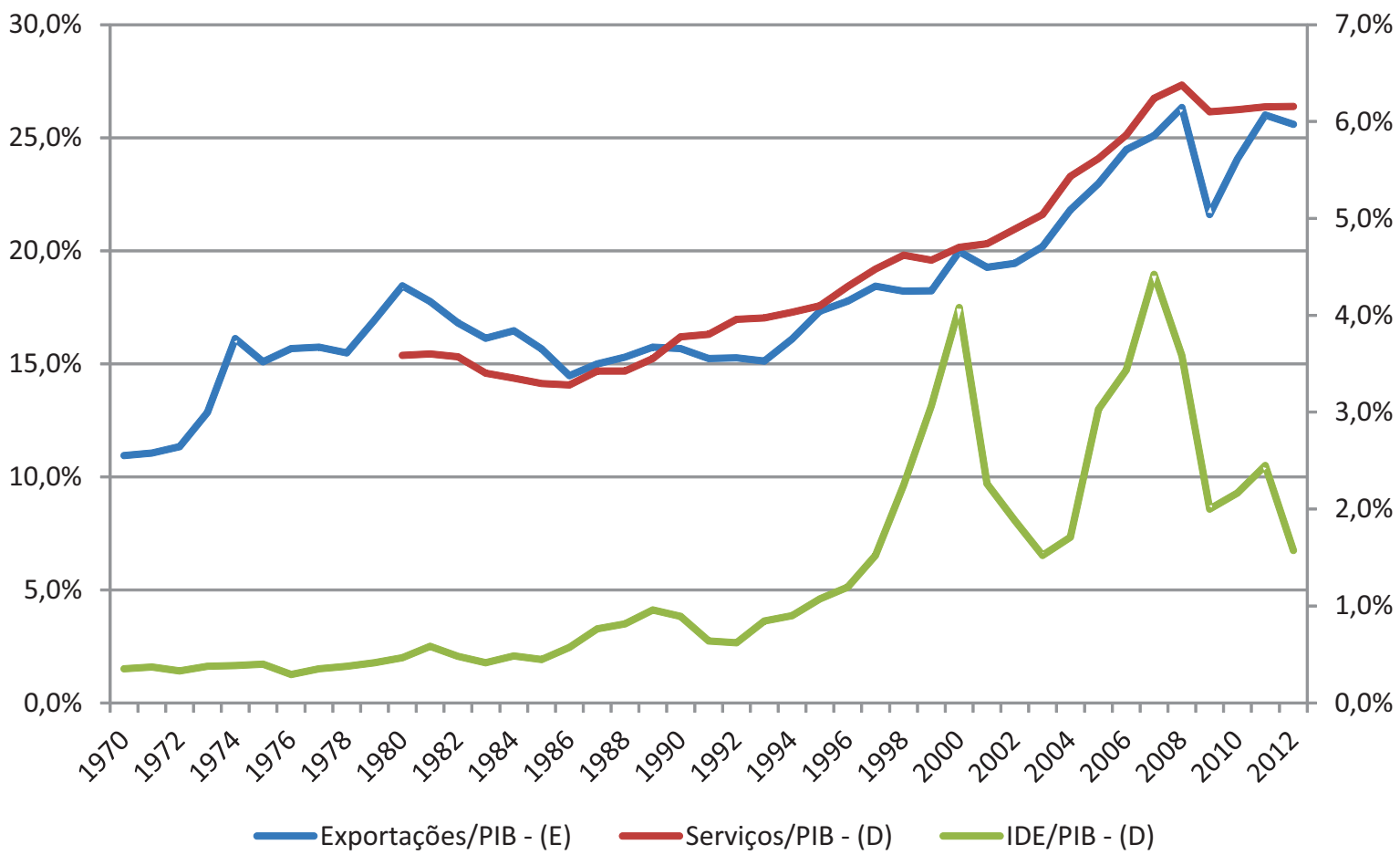

Fonte: elaboração dos autores com base em dados do World Development Indicators (WDI).

Dessa forma, as empresas americanas efetivaram ao longo dos anos 1980 um profundo processo de reestruturação, visando a associar a acumulação de ativos intangíveis com movimentos de racionalização e busca por flexibilidade, de maneira a responder ao mesmo tempo à pressão competitiva, à maior instabilidade das variáveis macroeconômicas e às exigências de retorno mais elevado e rápido, derivadas da crescente pressão do mercado financeiro sobre a gestão corporativa (Sarti \& Hiratuka, 2010).

A maior internacionalização, aliada à terceirização internacional de parcela crescente das etapas produtivas, passou a ser uma estratégia importante que resultou em uma grande descentralização das atividades produtivas. Em contrapartida, as grandes empresas buscaram reforçar seus ativos intangíveis e adquirir concorrentes estratégicos através de um processo intenso de fusões e aquisições. A elevação do poder de comando das grandes corporações dos países centrais sobre o valor gerado nas diferentes regiões foi potencializado, e o aumento do escopo global tornou-se um fator fundamental na luta competitiva, resultado das vantagens associadas à capacidade de diversificar riscos, operar em vários mercados, explorar diferenciais de custos e vantagens de localização em diferentes regiões.

Como pode ser visto no Gráfico 2, os valores das fusões e aquisições internacionais também apresentaram uma tendência clara de elevação desde os anos 1990, apesar das intensas flutuações ocorridas, seguindo o mesmo movimento observado nos fluxos de investimento estrangeiro direto (IDE). Depois de atingir um recorde de transações em 2007, quando superou o total de US\$ 1 trilhão, 
o movimento anual passou a oscilar em torno dos US $\$ 400$ bilhões anuais. A interpenetração entre os fluxos financeiros e os ativos reais também pode comprovada nesses dados, uma vez que a elevada liquidez internacional e a hipertrofia das transações financeiras resultaram em uma disponibilização ampla de recursos para alavancar a compra de ativos no mercado mundial, reforçando o processo de concentração e centralização do capital em nível global.

Gráfico 2 - Valor das fusões e aquisições internacionais (compras), em US\$ bilhões - 1990-2012

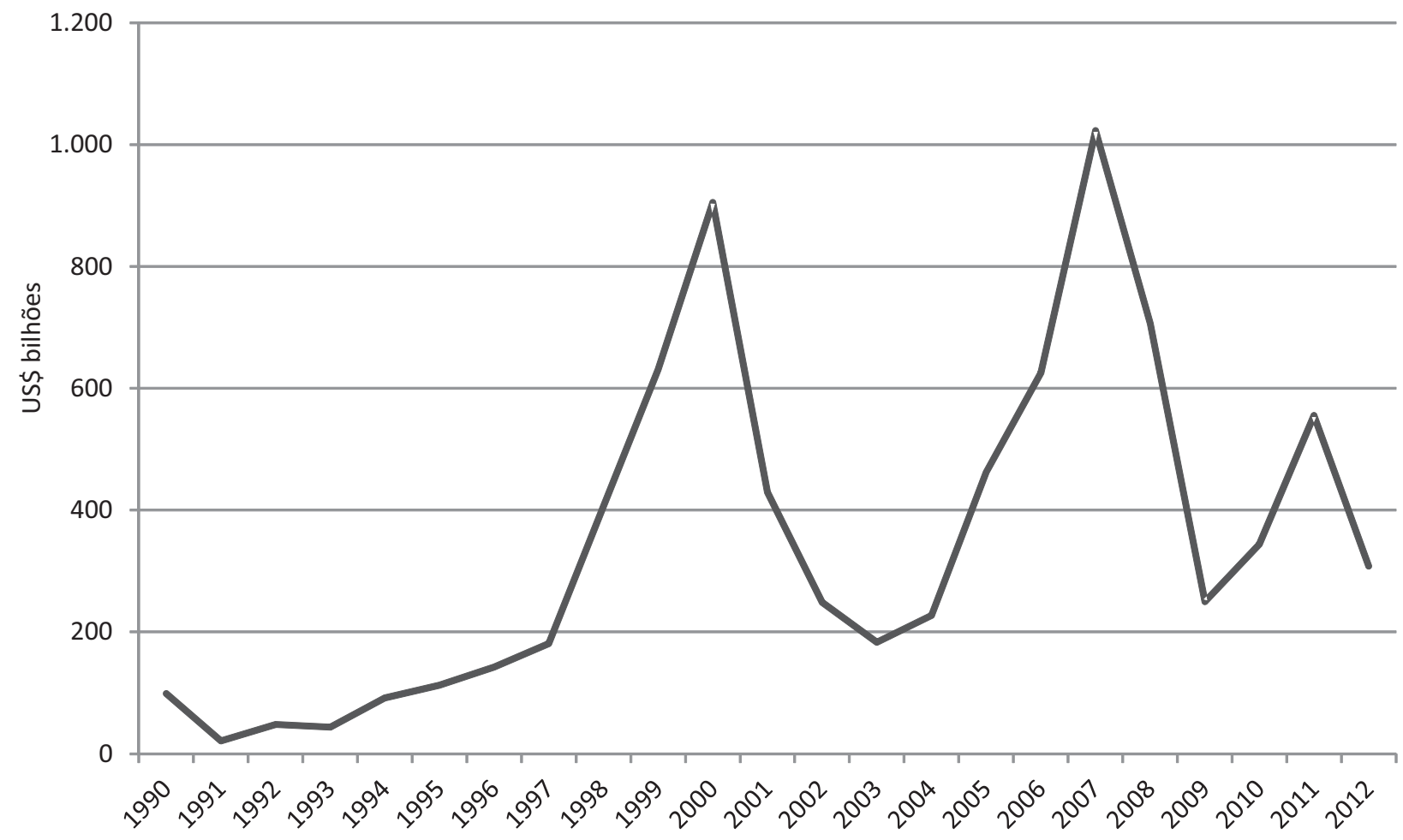

Fonte: elaboração dos autores com base em dados da United Nations Conference on Trade and Development (UNCTAD).

Separando as transações por grupo de atividade envolvida nas operações de fusões e aquisições, é possível perceber que a atividade de serviços representou grande parcela desse movimento. Mesmo não levando em consideração os serviços financeiros, que responderam na maioria dos anos pela maior parte do valor transacionado, os valores das fusões e aquisições são bastante significativos (Gráfico 3). 
Gráfico 3 - Valor das fusões e aquisições internacionais (compras) por atividade, em US\$ bilhões 1990-2012

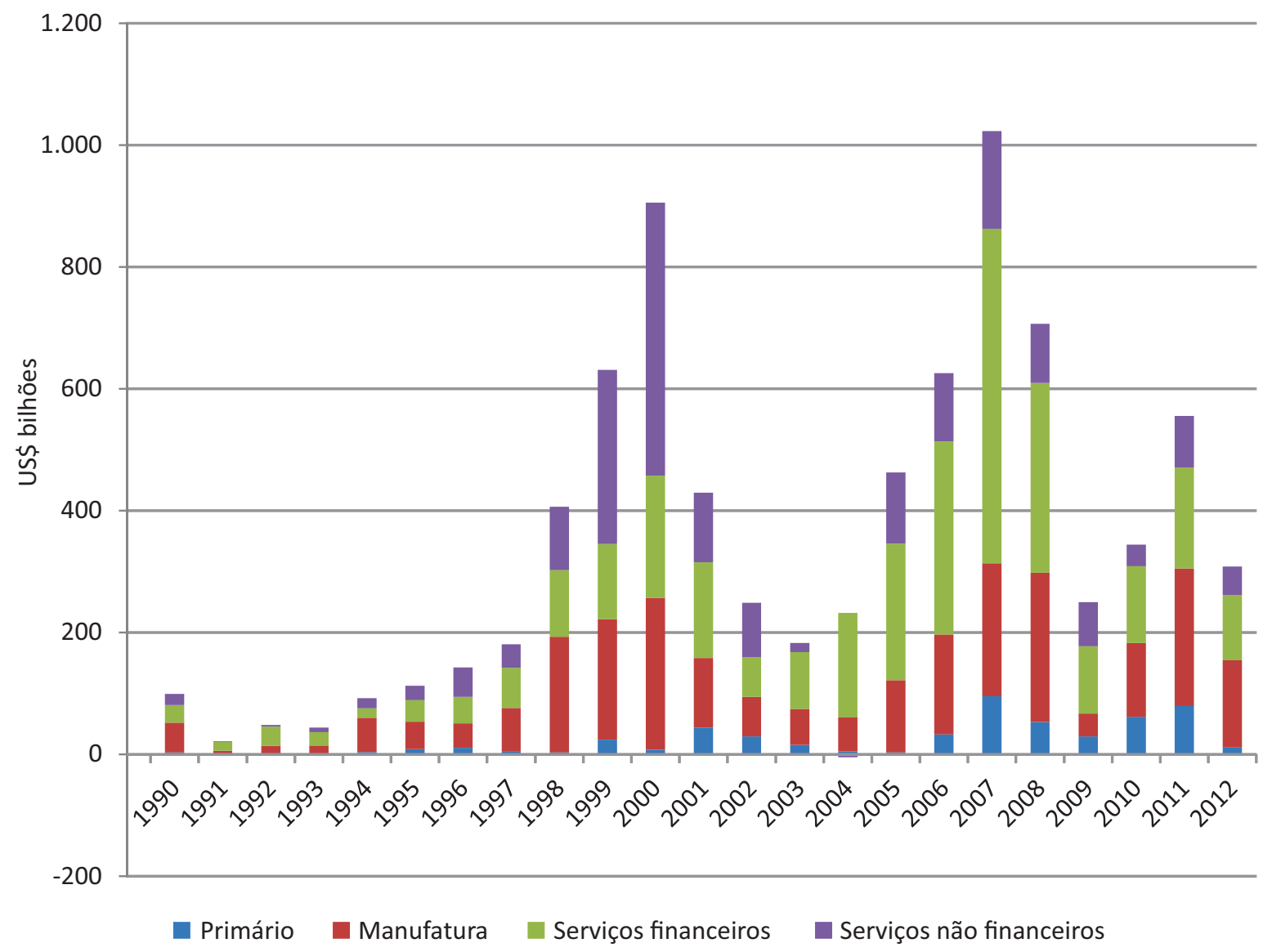

Fonte: elaboração dos autores com base em dados da UNCTAD.

Como destacado pela UNCTAD (2004), o aumento dos investimentos diretos e das fusões e aquisições no setor de serviços foi impulsionado tanto pelos processos de privatizações de setores, como telecomunicações e de energia, quanto pela liberalização ocorrida em diversos países, abrindo espaço para o capital estrangeiro em vários segmentos em que a regulamentação impedia a participação de capital externo. Também é importante ressaltar a diversificação dentro do segmento de serviços, englobando, além dos setores já citados, os de transporte, hotelaria e alimentação, e, posteriormente, atingindo setores que tinham sido menos afetados pela internacionalização, como educação e saúde.

Esses aspectos chamam atenção para a crescente internacionalização observada na economia mundial, acompanhada de um movimento intenso de reestruturação patrimonial com um processo expressivo de fusões e aquisições, resultando em um grau de centralização de capital sem precedentes em vários setores e atividades. Se, em um primeiro momento, as atividades industriais sofreram de maneira mais intensa esse processo, mais recentemente os setores de serviços têm sido afetados 
também. A princípio, os setores de energia e telecomunicações foram os vetores desse movimento, mas essa tendência tem se expandido para outros setores, mais diretamente relacionados com a oferta de serviços básicos à população e, portanto, também mais sujeitos à regulação estatal, como educação e saúde.

As análises das transformações recentes no setor de serviços de saúde no Brasil devem ter esse movimento como pano de fundo. A sua dinâmica, portanto, precisa ser entendida considerando os condicionantes colocados por essa tendência mais ampla de internacionalização mundial.

Antes, porém, de analisar especificamente as transformações no setor de serviços de saúde no Brasil, cabe realizar uma avaliação das características mais específicas das particularidades estruturais do setor, assim como uma análise mais detalhada das empresas líderes mundiais e de suas estratégias.

\section{Serviços de Saúde: caracterização internacional e empresas líderes}

\section{Caracterização geral}

Há uma série de fatores que torna a saúde, do ponto de vista da organização econômica, um setor repleto de particularidades, de difícil enquadramento nas normas convencionais de regulação dos mercados. Em outros termos, poucas características do setor de saúde justificariam deixar sua regulação à mercê meramente das leis de mercado. Esses fatores vão de uma estrutura peculiar de demanda e oferta ao relacionamento do setor com o avanço tecnológico, passando pela forma pela qual o risco e a assimetria de informação afetam a organização do setor. Esse cenário fornece ao setor, por vezes, uma dinâmica de concorrência com forte caráter concentrador, e, em se tratando de saúde, a criação de poder de mercado em relação ao consumidor é particularmente mais problemática do que o usual em outros mercados.

Dentro do macrossetor de saúde, as empresas prestadoras de serviços de saúde também se inserem nessa dinâmica. No segmento incluem-se empresas, tais como seguradoras e cooperativas de saúde, laboratórios de análises clínicas e serviços radiológicos, empresas administradoras e proprietárias de hospitais e clínicas e empresas de logística de saúde, como fornecedoras de insumos médicos e prestadoras de serviços de remoção. Compondo parte do macrossetor de saúde, esse conjunto de empresas, por um lado, compartilha algumas características gerais que definem a saúde como um setor econômico; por outro, por não estarem ligadas diretamente à produção, tais como as farmacêuticas ou as empresas de equipamentos médicos, têm uma lógica de concorrência própria pautada por alguns aspectos bem específicos ao seu conjunto de atividades.

A primeira questão de ordem geral diz respeito ao fato de o setor de saúde ser responsável pelo fornecimento de algo que é constitucionalmente reconhecido como um direito subjetivo, compondo parte dos direitos de cidadania e visando à universalidade de acesso, ao mesmo tempo que a saúde é uma mercadoria altamente geradora de valor (Conill, 2008). Ao reconhecimento desse problema deve-se, em boa parte, a organização dos sistemas nacionais de saúde, cuja organização afeta diretamente a lógica de atuação das empresas privadas. 
Destaca-se, ainda, o fato de o fornecimento de serviços de saúde ser uma atividade altamente geradora de externalidades positivas para o sistema econômico como um todo. Nesse sentido, o fornecimento de serviços em todos os níveis, e principalmente em atenção básica, contribui para a maior eficiência do funcionamento do setor, justificando a atuação da esfera pública na regulamentação e complementação da oferta de serviços.

A organização dos sistemas nacionais de saúde define em formas gerais a divisão de trabalho entre a esfera pública e a privada, assim como a estrutura de financiamento e as formas de remuneração das empresas privadas de serviços de saúde. Dessa forma, as modificações nos sistemas de saúde afetam os padrões de concorrência do setor, e este fenômeno pode ser facilmente percebido nas ondas de fusões, aquisições e mudanças nas estratégias das grandes empresas que se seguem às mudanças nas legislações que regulam os sistemas públicos de saúde. Além disso, o setor geralmente caracteriza-se também pela existência de empresas não lucrativas, como instituições religiosas e de caridade ou ligadas a grupos étnicos específicos.

No que tange à estrutura de demanda dos serviços de saúde, algumas características são particularmente importantes para compreender a relação entre usuários e empresas. Do ponto de vista do usuário, a demanda por serviços é marcada por uma forte assimetria de informação, entre ele e o especialista que os prescreve, impondo ao serviço demandado um caráter de necessidade, caracterizado pela baixa elasticidade-preço e, sobretudo, pela imprevisibilidade dessa demanda (Iunes, 1995). Dada também a incerteza a respeito da utilização e custos desses serviços, é normal a interposição de agentes administradores do risco, como seguradoras, que, por estarem geralmente associadas a uma rede específica de fornecedoras de serviços, tendem a restringir a livre substituição entre essas fornecedoras.

A visão de que o fornecimento de serviços de saúde é marcado principalmente por imperfeições de mercado, que o afasta do que seria o funcionamento adequado de um mercado segundo a teoria convencional, faz parte das contribuições do artigo seminal de Arrow (1963) sobre o tema. Segundo o autor, as imperfeições afetariam não só a estrutura de demanda como também a estrutura de oferta do setor. Primeiramente, em relação à capacidade das empresas de discriminar preço em relação às faixas de renda e realizar cobranças diferenciadas - como taxas extras vinculadas à utilização de certos serviços - que, associada a uma baixa elasticidade-preço, possibilita às empresas, como ensina qualquer manual convencional de microeconomia, uma grande capacidade de se apropriar do excedente do consumidor. Outro aspecto é a importância que a informação sobre o histórico dos pacientes e a aplicação de métodos de tratamento e diagnóstico tem na composição dos custos e na formação dos preços, o que contribui para gerar vantagens competitivas para formas mais concentradas de comando sobre a cadeia de empresas do setor, tais como empresas verticalizadas ou associações entre empresas.

No que se refere à assimilação de tecnologias por parte das empresas de serviços de saúde, embora estas não sejam geralmente produtoras de novas tecnologias, têm uma posição importante na disseminação tecnológica de novos métodos e produtos. Por concentrarem a oferta de serviços de saúde, as fornecedoras de serviços de saúde se estabelecem como interfaces entre o usuário final e as empresas inovadoras, definindo as condições de utilização e o ritmo da adoção de novas tecnologias. 
Nesse sentido, são responsáveis por boa parte do fornecimento das informações necessárias às mudanças incrementais, adaptações e ajustes para a utilização de novas tecnologias. Em muitos casos, as pesquisas são realizadas dentro das próprias empresas - como no caso dos hospitais e clínicas -, embora não tenham necessariamente a participação delas nos resultados e no financiamento. Mesmo assim, a cooperação entre os diversos elos da cadeia de fornecimento de serviços de saúde para a geração de certa estabilidade e continuidade das condições de pesquisa é fundamental para o avanço tecnológico na área.

Da perspectiva das empresas de serviços de saúde, a adoção de novas tecnologias também significa, em muitos casos, custos fixos crescentes. Dada a capacidade de discriminação de preços e de cobranças diferenciadas por serviços, o uso de novas tecnologias constitui um fator de competitividade e de aumento da rentabilidade via diferenciação da oferta, o que induz um ritmo acelerado na adoção de inovações e, simultaneamente, fortes pressões para ampliar a escala de operação. Este movimento acaba gerando um viés concentrador na disputa, sobretudo, em relação aos novos mercados.

Desse modo, a dinâmica concorrencial fica sujeita a uma tendência constante de aumento da importância das economias de escala, enquanto as mudanças na organização dos sistemas públicos de saúde podem contribuir para ampliar ou reduzir o espaço de atuação das empresas, assim como impor limites a práticas discriminatórias de preços e a certas condutas estratégicas das empresas líderes. Esses conflitos podem reduzir o mercado das empresas, levando-as à adoção de estratégias de diversificação e internacionalização mais ou menos acirradas.

Tal cenário foi particularmente o que se apresentou nos anos recentes, caracterizado por um conjunto de mudanças na organização dos sistemas públicos de saúde nos países centrais. Essas mudanças levaram as empresas a buscar a ampliação de seus espaços de atuação e suas escalas de operação, internacionalizando e verticalizando as atividades, o que provocou mais uma onda de fusões e aquisições. Contribui para a velocidade desse processo o aporte de capital proveniente de diversos fundos financeiros, que têm procurado adquirir participação em grandes empresas de serviços de saúde ou formar joint ventures para o processo de crescimento de alguma delas (Patterson, 2013).

As operações totais de fusões e aquisições realizadas globalmente apresentam uma tendência clara de aumento desde o início dos anos 2000 (Gráfico 4). O número de operações registrado foi de 39 em 1999, crescendo rapidamente a partir de então, até chegar a 415 operações em 2008. A crise internacional faz com que ocorra uma queda em 2009, porém o crescimento volta a acontecer a partir de 2010. O ano de 2012 registrou o recorde de 432 operações, seguido por pequena queda em 2013. Em termos de valor, ${ }^{1}$ a ocorrência de algumas operações com valor elevado torna a série mais volátil, com picos em 2003 e 2004, quando foram atingidos valores superiores a US\$ 30 bilhões. No entanto, mesmo com a redução posterior, o patamar das operações globais permanece entre U\$ 10 e 15 bilhões por ano.

\footnotetext{
${ }^{1}$ Nem todas as operações têm informações de valor registradas. O valor das operações corresponde apenas à soma das operações com valor registrado.
} 
Esse fenômeno tem acelerado o ritmo de concentração do mercado e contribuído para o crescimento do porte das principais empresas globais. O aumento da renda dos países em desenvolvimento, resultando no surgimento de uma ampla gama de novos consumidores, permitiu a esse processo ganhar fôlego e acirrar a corrida à aquisição de ativos estratégicos para o aproveitamento desses mercados.

Gráfico 4 - Fusões e aquisições no setor de serviços de saúde, em número de operações e valor, em US\$ bilhões - 1997-2013

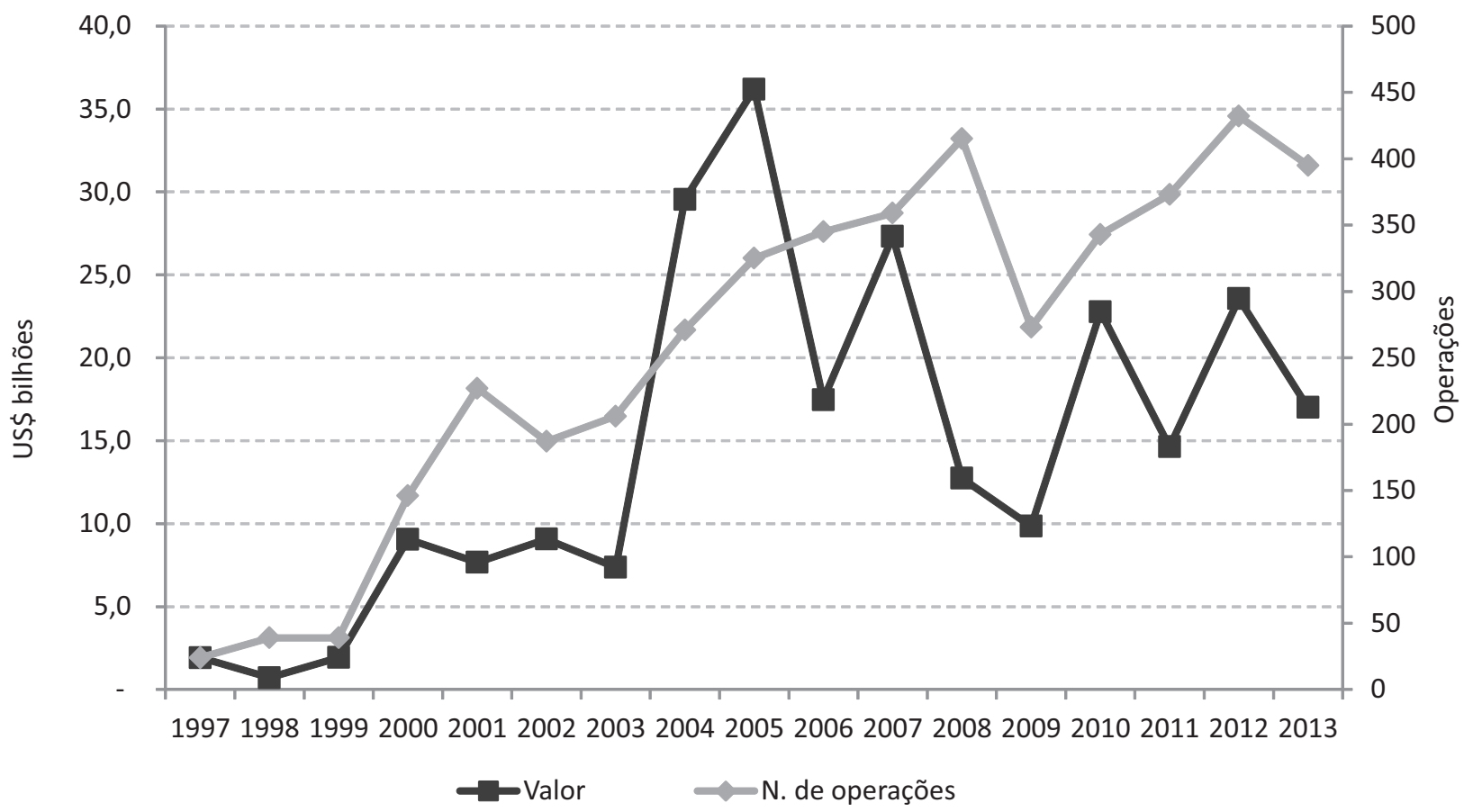

Fonte: elaboração dos autores com base em dados da Zephir-Bureau van Dijk (BvD).

Considerando apenas os processos de fusões e aquisições internacionais, isto é, quando as empresas adquirentes e adquiridas são de países diferentes, observa-se também uma elevação ao longo dos últimos anos. O número de operações foi de apenas cinco em 1997, e passou a registrar crescimento acentuado, chegando a 62 em 2008. Após a crise, observa-se uma desaceleração, porém em 2013 o número de operações atinge novo recorde, com 64 operações registradas. Em termos de valor, os patamares apresentam um crescimento consistente, especialmente a partir de 2004, quando, apesar da volatilidade, é possível perceber um volume de transações com valor mais elevado. O ano de 2012 marca o auge dos valores registrados, com US\$ 6,6 bilhões (Gráfico 5). 
Gráfico 5 - Fusões e aquisições internacionais no setor de serviços de saúde, em número de operações e valor, em US\$ bilhões - 1997-2013

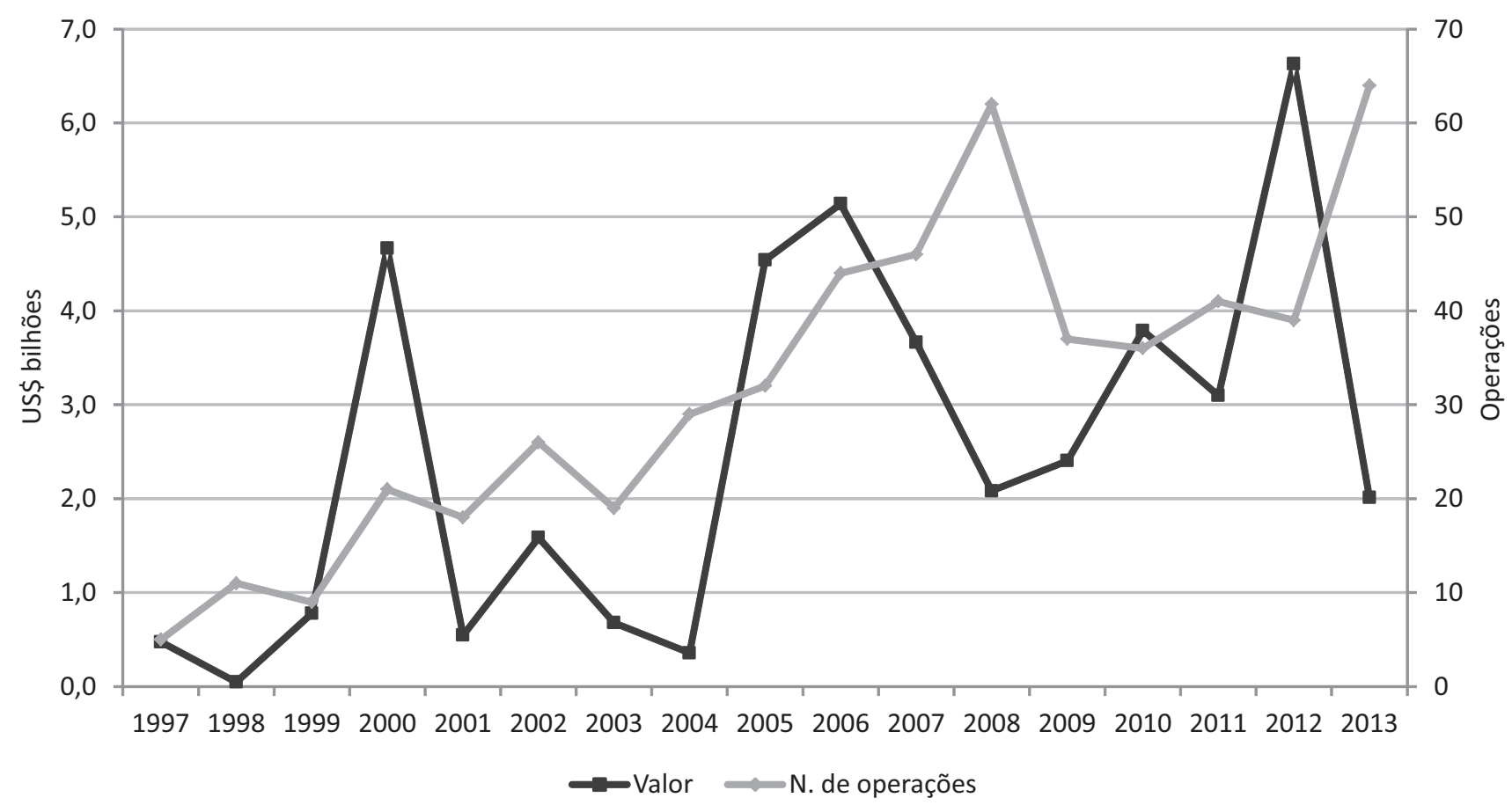

Fonte: elaboração dos autores com base em dados da Zephir-Bureau van Dijk (BvD).

O movimento de concentração iniciado nos países centrais vem se espalhando para os países em desenvolvimento, tendo como efeito o aumento da participação de empresas estrangeiras nos sistemas nacionais de saúde destes países. A seção seguinte apresenta as principais características do crescimento das maiores empresas de serviços de saúde que operam internacionalmente.

\section{Crescimento recente das empresas líderes de serviços de saúde}

O impacto da crise econômica sobre os sistemas nacionais de saúde dos países desenvolvidos se fez sentir na reorganização dos gastos sociais a partir da restrição da política fiscal a que muitos deles ficaram sujeitos. Ao mesmo tempo, a própria crise provocava o crescimento do desemprego e da pobreza, e exigia desses sistemas uma ampliação dos cuidados necessários à população com renda mais baixa. Os efeitos sobre as empresas dos países desenvolvidos foram bem assimétricos, resultando, em alguns casos, como nos Estados Unidos, em um forte movimento de concentração e internacionalização em direção a mercados em expansão. ${ }^{2}$ Esse movimento foi acompanhado do surgimento de novas sociedades entre empresas e fundos financeiros. As sociedades formadas

\footnotetext{
2 O número de fusões e aquisições na área de serviços de saúde mais do que dobrou no período pós-crise nos Estados Unidos - chegou a 105 operações somente no ano de 2012 -, criando a segunda maior onda de fusões e aquisições desde a rodada de concentrações ocorridas após a reforma de 1990 de Hillary Clinton.
} 
permitiram uma capitalização considerável, elevando em média o tamanho das empresas envolvidas na disputa internacional dos mercados de serviços de saúde.

As principais empresas de serviços de saúde selecionadas aqui - UnitedHealth, Hospital Corporation of America (HCA), Community Health Systems, Fresenius Medical Care, NetCare, Ramsay Helath Care, Kindred Healthcare, Rhön-Klinikum AG (RHK) e Capio AB - representam um grupo significativo desse processo. Ainda que a presença da família fundadora não seja incomum em algumas empresas de grande porte, a composição dos acionistas minoritários também vem se tornando característica. A formação de consórcios de fundos financeiros de grande porte tem sido o principal fator determinante da dinâmica de concentração do mercado internacional (Tabela 1).

Tabela 1 - Receita operacional e ativos totais das empresas de serviços de saúde escolhidas, em US\$ bilhões - 2012

\begin{tabular}{|l|c|c|c|}
\hline \multicolumn{1}{|c|}{ Empresa } & Origem & Receita operacional & Ativos totais \\
\hline UnitedHealth & EUA & 99,7 & 80,8 \\
\hline HCA & EUA & 18 & 63 \\
\hline Community Health & EUA & 13 & 16,6 \\
\hline Fresenius AG & Alemanha & 72 & 112 \\
\hline NetCare & África do Sul & 7,3 & 16,4 \\
\hline Ramsay Health Care & Austrália & 4 & 3,7 \\
\hline Kindred Healthcare & EUA & 4,9 & 4,2 \\
\hline RHK & Alemanha & 4 & 4,2 \\
\hline Capio AB & Suécia & 1,6 & 2 \\
\hline
\end{tabular}

Fonte: elaboração dos autores com base em dados da Zephir-Bureau van Dijk (BvD).

A UnitedHealth, a maior das empresas analisadas, é emblemática nesse sentido. Fundada em meados da década de 1970 por uma associação de médicos, abriu capital em 1984 e iniciou uma série de aquisições no começo dos anos 1990, terminando a década já como um dos principais conglomerados do setor nos Estados Unidos. Seguindo a trajetória de concentração do mercado norte-americano, a UnitedHealth iniciou nos anos 2000 mais uma rodada de aquisições, incluindo algumas grandes empresas. Ao longo da última década adquiriu a Pacificare Health Systems por cerca de US\$ 8,7 bilhões, a Oxford Health Plans por US\$ 5 bilhões, a Sierra Services por cerca de US\$ 3 bilhões e a Amil, principal ativo da companhia fora dos Estados Unidos, por aproximadamente US\$ 6 bilhões.

A participação dos fundos financeiros foi fundamental nesse processo. A UnitedHealth possui uma estrutura acionária bastante pulverizada, composta por vários fundos de investimento, dos quais o Blackrock é o principal controlador com 6,2\% das ações. O Blackrock, por sua vez, é composto por um conjunto grande de sócios, entre os quais os mais importantes são o PNC Financial, Wellington Management, Barclays, o governo da Noruega e o JP Morgan. Ao longo desse período, com o aporte 
de capital dado pelos fundos ao seu processo de crescimento, a UnitedHealth tornou-se a maior empresa do setor nos Estados Unidos e uma das maiores do mundo, com receita operacional próxima de US\$ 100 bilhões de dólares e com ativos totais de cerca de US\$ 80 bilhões em 2012.

A Hercules Holding Inc., proprietária da HCA, embora mais recente, apresenta uma história semelhante. A companhia passou a ocupar a posição de segundo maior conglomerado de saúde nos Estados Unidos, depois de um rápido processo de crescimento via fusões e aquisições financiadas por fundos de investimento. A holding foi organizada a partir de 2006 com o fechamento do capital e incorporação dos ativos da HCA pela Hercules Holding, que passou a controlar os ativos reunidos da área de serviços de saúde. É controlada atualmente por um consórcio grande de fundos de investimento, cujos principais acionistas são Bain Capital Investors e Kohlberg Kravis Roberts \& Co. (KKR), entre outros fundos sediados principalmente nos Estados Unidos e Reino Unido.

Após a incorporação da HCA pela Hercules Holding, a companhia adquiriu uma série de hospitais, clínicas e laboratórios na Austrália, Canadá, Suécia, Finlândia e Reino Unido. Esse processo foi acompanhado da reestruturação dos negócios da holding nos Estados Unidos, com a venda de um conjunto vasto de hospitais de médio porte e a concentração dos negócios em redes de grandes hospitais. A companhia também focou sua estratégia na compra de empresas de planos de saúde, sobretudo no Reino Unido. Em 2014 o fundo Bain Capital, controlador da holding, anunciou a compra do Grupo NotreDame Intermédica, sediado em São Paulo, com negócios na área de seguros de saúde, centros clínicos, hospitais e prontos-socorros.

A companhia reúne atualmente cerca de 2.400 subsidiárias, espalhadas por mais de dez países, atuando em seguros de saúde, análise clínica, assistência médico-hospitalar e logística médica. No ano de 2013, essas subsidiárias apresentaram uma receita operacional de cerca de US\$18 bilhões, com ativos totais na ordem de US $\$ 63$ bilhões, compondo um dos maiores conglomerados de serviços de saúde dos Estados Unidos. Deve-se ressaltar também que os principais controladores da holding, Bain Capital e KKR, participam do controle de outra série de empresas independentes que atuam no segmento de serviços de saúde nos Estados Unidos e em outros países.

O Community Health Systems pode ser considerado o terceiro grande conglomerado formado nos Estados Unidos a partir dos fundos financeiros. A companhia é controlada pelos fundos Glenview Capital Management, Baron Capital e Blackrock, com 10,6\%, 6,15\% e 5,6\% respectivamente, acompanhados por um vasto número de pequenos acionistas. O fundo Blackrock também consta entre os principais acionistas da UnitedHealth e da Kindred Healthcare. Em 2012, o Community Health encerrou o ano com receita operacional de US\$13 bilhões aproximadamente e um total de ativos de US\$16,6 bilhões.

O conglomerado apresentou também um crescimento recente sustentado pela atuação dos fundos de investimentos, através da capitalização de uma estratégia acirrada de compra de outras grandes empresas. Esse processo permitiu que o Community Health triplicasse de tamanho entre os anos de 2006 e 2008. A partir de 2007, a empresa adquiriu a Triad Hospitals por cerca de US\$ 7 bilhões, a Tenet Healthcare por US\$ 7,5 bilhões, e recentemente a Health Management por aproximadamente US $\$ 8$ bilhões. A rodada de compras do Community Health, somada às grandes aquisições dos outros 
três grandes conglomerados com base de operação nos Estados Unidos, fornece bem uma ideia da proporção que a concentração do mercado norte-americano vem tomando a partir da onda de fusões e aquisições da segunda metade da década de 2000.

O maior conglomerado do setor fora dos Estados Unidos, o grupo alemão Fresenius, controlador da Fresenius Medical Care, reúne ativos na área da saúde da ordem de US\$ 112 bilhões, com uma receita operacional em 2012 de aproximadamente US\$ 72 bilhões. O grupo tem como principal acionista a empresa familiar alemã Else Kroener-Fresenius, mas conta também com um grande número de pequenos acionistas, entre os quais se destacam o Skandinaviskan Enskilda Banken (SEB) e a Allianz, além de outros fundos de investimento de diferentes nacionalidades.

Seguindo a mesma lógica, o grupo iniciou nos anos 2000 uma série de aquisições de grande porte. Em 2001, a Fresenius adquiriu a Wittgensteiner Kliniken e, em 2005, o grupo adquiriu a Helios, terceira maior administradora de hospitais da Alemanha. Nesse período, a Frenesius ainda comprou a Renal Care Group, a APP Pharmaceuticals, a National Medical, a Liberty Dialysis Holding, a American Access Care Holdings e a Everest Healthcare, entre outras empresas que serviram de base para a ampliação dos negócios do conglomerado nos Estados Unidos. Nos países em desenvolvimento, o grupo expandiu sua presença na Índia - com a aquisição da Dabur Pharma e da Goa Formulations, ambas no setor de fármacos, e a Mafatlal Industries, produtora de equipamentos -, China, Taiwan, Singapura, México, Colômbia e Argentina.

O grupo também aumentou significativamente a presença em vários países europeus. De modo geral, a Frenesius aproveitou seu negócio original ligado aos tratamentos de diálise para diversificar as atividades em um conjunto vasto de negócios. Além das atividades de serviços médicos, o conglomerado verticalizou suas atividades para equipamentos médicos em geral, química fina, fármacos - incluindo de uso veterinário - e complementos nutricionais, setor em que vem demonstrando recentemente interesse na aquisição dessa divisão de negócios da Danone. A companhia ainda atua na América Latina em serviços de tecnologia da informação para a área da saúde em uma joint venture com a NetCare.

A NetCare é um conglomerado de capital sul-africano e inglês que opera majoritariamente na área de assistência médico-hospitalar, análise clínica e seguros de saúde. A receita operacional do grupo como um todo para 2012 foi de aproximadamente US\$ 7 bilhões, e os ativos totais contabilizaram cerca de US\$ 16 bilhões. A Netcare é controlada pelo fundo de investimentos Coronation Fund Managers, com atuação principalmente no continente africano, mas com uma ampla carteira de negócios que inclui participações relevantes na indústria automotiva, moda, indústria extrativa, telecomunicações e outras atividades em diversos países. O fundo, além do capital sul-africano, conta com um grupo vasto de capitais de diferentes nacionalidades, mas principalmente advindos de fundos norte-americanos e britânicos.

O conglomerado concentrou sua estratégia em aquisições no Reino Unido e África do Sul, salvo alguns casos isolados de compra de ativos nos Estados Unidos e Portugal. Entre essas aquisições, possivelmente a de maior importância foi a do General Healthcare Group, no Reino Unido, em 2006. A aquisição envolveu um consórcio de fundos de investimento, incluindo o Apax Partners, 
fundo controlador da Capio AB. A General Helthcare Group iniciou nos últimos anos um processo de recapitalização, por meio da venda de ativos não considerados estratégicos e de emissões primárias de ações. A partir da capitalização da General Healthcare, a NetCare adquiriu um conjunto de hospitais da Nuffield - outro grande grupo inglês de serviços de saúde - e vem transformando a General Healthcare na base da expansão do grupo Netcare no Reino Unido.

Outra empresa do hemisfério sul de crescimento acelerado foi a australiana Ramsay Health Care. A companhia acelerou esse processo via aquisições, iniciando a expansão a partir de 2000 , com as aquisições de quatro grandes empresas do setor na Austrália - a Affinity Health, a Australian Hospital Care, a Alpha Healthcare e a Benchmark Healthcare -, enquanto recebia o aporte de capital de alguns fundos importantes como o Barclays, do Reino Unido, e o FMR e o Fidelity International, ambos dos Estados Unidos. O grupo obteve em 2012 uma receita operacional de US $\$ 4$ bilhões aproximadamente e reunia ativos no valor de cerca de US\$ 3,6 bilhões. A importância do processo de capitalização para o crescimento da empresa fica claro quando observado o seu desempenho na última década - desde 2004 a receita operacional da companhia aumentou acima de $600 \%$, enquanto os ativos totais cresceram de US\$ 475 milhões para cerca de US\$ 3,7 bilhões no mesmo período.

Após a rodada de concentração no mercado australiano, a Ramsay Health Care expandiu seus negócios para o Reino Unido, França, Indonésia e Malásia. No Reino Unido, além da compra de algumas redes de hospitais de menor porte, a companhia adquiriu os negócios da Capio UK em 2007, subsidiária do grupo sueco Capio AB. Depois de algumas aquisições na França, em 2010 a companhia comprou 57\% do capital da Proclif, empresa que passou a reunir os ativos da Ramsay no mercado francês, passando a chamar-se Ramsay Santé. Em 2103, a Ramsay estabeleceu uma joint venture com o conglomerado malaio Sime Derby para a exploração de serviços de saúde no Sudeste Asiático - a Ramsay Sime Derby Healthcare.

A Kindred Healthcare, ao contrário das demais empresas líderes, permaneceu concentrada em sua principal área de negócios, assistência médico-hospitalar, e com a estratégia focada em seu mercado doméstico, os Estados Unidos, ao longo de toda a década. A exceção fica por conta da diversificação para a distribuição e revenda de fármacos, por meio da Kindred Pharmacies, e para a abertura de capital da Kindred Biosciences, recém-fundada empresa de fármacos para uso veterinário do grupo.

A Kindred é controlada por um conjunto de fundos de investimentos, cada um com pequena porcentagem de ações na companhia. O principal acionista é novamente o Blackrock, seguido pelo Wellington Management e pelo Dimensional Fund. Para o ano de 2012, a receita operacional alcançou a cifra de US\$ 4,9 bilhões, com o valor dos ativos totais de aproximadamente US\$ 4,2 bilhões. A companhia concentrou sua política de compra em empresas nos Estados Unidos que atuassem em seu core business, entre as quais as principais aquisições foram a RehabCare, por cerca de US\$ 1,3 bilhão, a Triumph Healthcare, por US\$ 500 milhões, e a Commonwealth Communities Holdings, por US\$ 125 milhões.

De modo geral, a Kindred focou seu crescimento na aquisição de hospitais, clínicas de reabilitação e de cuidado com idosos e em empresas de enfermagem especializada. A atuação dos fundos 
financeiros, assim como nos outros casos, serviu para impulsionar a rápida concentração desses mercados através da capitalização da estratégia de aquisição da companhia. Embora a Kindred não tenha iniciado seu processo de internacionalização, a concentração dos mercados de serviços de saúde nos Estados Unidos e o porte já assumido pela empresa após o processo de aquisição dos grupos concorrentes tornam bem provável sua internacionalização nos próximos anos, seguindo o movimento já iniciado pelos conglomerados líderes de mercado.

A RHK é a segunda maior empresa de serviços de saúde no mercado alemão. Embora tenha controle familiar, a companhia tem um alto percentual de ações em free float e a participação de alguns acionistas importantes, como o fundo JP Morgan e o grupo Fresenius, com 5\% do capital, formando uma participação acionária cruzada interessante entre duas grandes empresas concorrentes no mercado alemão. A receita operacional da RHK foi em 2012 de cerca de US\$ 4 bilhões, e os ativos totais alcançaram a cifra de US\$ 4,2 bilhões. Assim como a Kindred Health Care, a RHK concentrou seus negócios no mercado doméstico focado na construção, operação e administração hospitalar, crescendo com a aquisição de empresas na mesma área e aumentando gradualmente sua escala de operação.

Entre os anos de 2006 e 2009, a RHK iniciou um processo de aquisições, cujas principais compras foram a Amper Kliniken AG, a Wesermarsch-Klinik e o St. Petri-Hospitals. O processo de crescimento do grupo foi em grande parte financiado por um aporte de cerca de US\$ 1 bilhão, através da emissão de títulos subscritos por um consórcio de bancos liderado pelo Commerzbank AG e pelo Morgan Stanley. A capitalização do grupo permitiu elevar seu capital em torno de 50\% e garantir o aumento da participação da RHK no disputado mercado alemão. Assim como a Kindred Health Care, a RHK é uma das poucas, entre as grandes empresas, que manteve seu crescimento contido ao mercado doméstico.

A Capio AB é um conglomerado sediado na Suécia, controlado pelos fundos Apax Partners e Nordic Capitals, que possuem cerca de duzentas empresas nas áreas de finanças, empreendimentos imobiliários, tecnologia em tratamentos médicos e serviços de saúde, com atuação principalmente em assistência médico-hospitalar e planos de saúde. No ano de 2012, a receita do grupo foi de aproximadamente US\$ 1,6 bilhão de dólares, com um total de ativos de cerca de US\$ 2 bilhões. Está presente em quase toda a Europa, embora controle suas operações a partir das sedes na Suécia, Noruega, França, Alemanha e Reino Unido. A internacionalização do grupo, ainda que restrita ao continente europeu, foi bem ampla, com negócios relevantes na Espanha, Suíça, França, Dinamarca, Noruega, Alemanha, Reino Unido e Itália, para citar apenas as operações de maior porte.

Entre as empresas líderes, a Capio é a que apresenta maior grau de internacionalização, com cerca de $50 \%$ da receita gerada fora do mercado doméstico. A companhia investiu na aquisição do controle de algumas grandes empresas, como a suíça Unilabs, a UK Healthcare e a Community Hospitals - ambas no Reino Unido -, o Grupo Sanitario - na Espanha - e o Tonkin Group - na França. Posteriormente desfez-se de alguns ativos importantes, entre os quais o principal foi a venda da Capio UK para a Ramsay Health Care por cerca de US\$ 316 milhões. Entretanto, a internacionalização do grupo ainda está em fase de expansão, tanto em relação aos negócios da Capio $\mathrm{AB}$, quanto aos negócios na área de saúde do fundo Apax Partners, principal controlador do grupo. 
De modo geral, a associação entre fundos financeiros e empresas de serviços de saúde contribui para a rápida concentração e internacionalização dos mercados dos países de alta renda. No caso dos Estados Unidos, em que o mercado de saúde combina renda per capita alta com grande participação dos gastos privados - ao contrário dos países europeus com grandes sistemas públicos de saúde centralizados -, o nível de concentração alcançou patamares bastante elevados, com a formação de alguns dos maiores conglomerados do setor.

O processo também teve em comum algumas características em relação à conduta dos fundos financeiros. A entrada dos fundos coincidiu com um movimento de recompra de ações e fechamento de capital de algumas unidades intermediárias dos grandes grupos. Esse movimento resultou na composição de algumas grandes holdings de serviços de saúde comandadas por consórcios bem vastos de fundos de investimento, geralmente com participação acionária pulverizada e com participação de fundos de diferentes nacionalidades. A consolidação do processo vem reduzindo cada vez mais o número de hospitais, clínicas e laboratórios independentes das grandes redes que, por seu turno, vêm se tornando cada vez mais internacionalizadas.

Alguns grandes fundos como o Apax Partners, o Blackrock Inc., o Bain Capitals e o Cinven Group, ao longo da década aumentaram significativamente suas participações em diversos empreendimentos na área da saúde, espalhados em diversos continentes. Embora alguns sejam concentrados em grandes empresas do setor, a participação desses fundos é bem mais vasta que o volume de ativos reunidos nas empresas líderes; e, até mesmo pela sua liquidez no mercado de capitais e pelo alcance global de suas operações, eles vêm dando a tônica do processo de concentração. A concentração nos mercados centrais já atingiu um nível elevado, restando apenas algumas possíveis aquisições de grande porte.

Outra característica relevante dos mercados desenvolvidos é que a divisão de trabalho entre Estado e setor privado é bem restrita ao setor privado, dada a abrangência dos sistemas públicos de saúde, limitando assim também o número de atividades em que a diversificação é possível. A formação de um vasto mercado de renda per capita mais elevada nos países em desenvolvimento, com sistemas públicos de saúde precários ou de pouca abrangência, fornece um mercado em potencial para o crescimento da participação dos fundos financeiros, em mercados com taxas de expansão mais elevadas que os seus mercados domésticos originais.

\section{O Setor de Serviços de Saúde Privados no Brasil}

\section{Caracterização geral}

O setor brasileiro de provisão de serviços de saúde, medido com base nos dispêndios totais com hospitais (públicos e privados), clínicas, serviços médicos, medicamentos e equipamentos médicos, totalizou cerca de US\$ 240 bilhões em 2012. A taxa de crescimento entre 2008 e 2012 foi de 12,5\%, comparada com uma taxa de 4,6\% observada nos Estados Unidos e 4,8\% no Canadá (Marketline Industry Profile, 2013).

O Sistema Único de Saúde (SUS) é responsável pelo provimento geral de serviços de saúde universal. Nos últimos anos, porém, tem ocorrido uma movimentação importante no segmento de 
saúde suplementar, com alguns sinais de que o cenário de maior concorrência internacional, abordado na seção anterior, tem se verificado de maneira mais efetiva no Brasil, em especial no período pós-crise internacional. Os dados de crescimento apresentados anteriormente permitem perceber o diferencial em termos de taxa de crescimento entre o Brasil e Estados Unidos e Canadá, o que justifica esse interesse.

O intenso processo de alterações na estrutura do setor de serviços de saúde em nível mundial tem tido repercussões importantes na economia brasileira. Esta seção busca justamente detalhar o sentido geral dessas transformações, descrevendo as linhas gerais de mudanças observadas. Antes de entrar diretamente na análise das mudanças, serão apresentados alguns dados básicos sobre a estrutura do setor de serviços de saúde no Brasil.

Na introdução deste estudo, afirmou-se que a atenção estaria concentrada em especial nos setores de seguros e planos de saúde, hospitais e serviços de diagnóstico. Também nesta seção a atenção vai convergir para esses setores.

Antes, porém, é interessante ter uma visão mais geral das atividades relacionadas aos serviços de saúde no Brasil, com base nas estatísticas disponíveis. De acordo com as informações do Cadastro Central de Empresas do Instituto Brasileiro de Geografia e Estatística (IBGE), os dados por grupo de atividade da Classificação Nacional de Atividade Econômica (CNAE), versão 2.0, foram organizados basicamente em dois segmentos principais. O primeiro faz parte de uma divisão do setor financeiro e é composto pelos grupos de classificação Seguros de Saúde e Planos de Saúde. Já o segundo corresponde especificamente à divisão atividades de Atenção à Saúde Humana e todos os seus grupos.

Os dados da Tabela 2 mostram como, em geral, o número de empresas que atuam em cada grupo de atividade é bastante grande, com exceção do segmento Seguros de Saúde. Também é possível perceber que o número de empresas e organizações pertencentes à divisão de serviços de Atenção à Saúde Humana é muito maior do que à de Seguros e Planos de Saúde. Apesar disso, o setor de Seguros e Planos de Saúde possui número médio de pessoas empregadas e salário médio também maior. Essas informações indicam um grau um pouco maior de concentração econômica neste grupo, comparado com uma pulverização bastante grande no setor de serviços de Atenção à Saúde Humana. 
Tabela 2 - Dados selecionados de empresas do setor de serviços de saúde, por grupo de atividade - 2011

\begin{tabular}{|l|c|c|c|c|c|}
\hline $\begin{array}{l}\text { Grupo da classificação de } \\
\text { atividades }\end{array}$ & $\begin{array}{c}\text { Empresas } \\
\text { e outras } \\
\text { organizaçeses }\end{array}$ & $\begin{array}{c}\text { Pessoal } \\
\text { ocupado em } \\
31 / 12\end{array}$ & $\begin{array}{c}\text { N. médio } \\
\text { de pessoas } \\
\text { ocupadas em } \\
31 / 12\end{array}$ & $\begin{array}{c}\text { Salários } \\
\text { e outras } \\
\text { remunerações } \\
\text { (R\$ 1.000) }\end{array}$ & $\begin{array}{c}\text { Salários e } \\
\text { remunerações } \\
\text { médios }\end{array}$ \\
\hline R\$ 1.000)
\end{tabular}

Fonte: elaboração dos autores com base em dados do Cadastro Central de Empresas do IBGE.

Entre os serviços de atenção à saúde humana, deve-se destacar a elevada participação dos hospitais, tanto no número de pessoas ocupadas quanto nos salários e remunerações pagos (60\% e $75 \%$ respectivamente). Também é válido destacar que as organizações de atendimento hospitalar têm tamanho médio e salário médio superiores ao do conjunto do setor. Especificamente no setor de atendimento hospitalar, cabe ressaltar que, embora as organizações pertencentes diretamente ao setor público respondam por apenas $2,3 \%$ do total, elas representam mais de $26 \%$ do pessoal ocupado e $35 \%$ dos salários e remunerações. Este fato está relacionado ao grande porte dos hospitais públicos, com número médio de empregados maior do que 1,3 mil em 2011. Os hospitais sem fins lucrativos, também denominados filantrópicos respondem por 44\% do pessoal ocupado e 43\% das remunerações, embora sejam responsáveis por $15 \%$ das organizações. O setor privado, por sua vez, apresenta tamanho médio muito menor, representa a grande maioria das organizações (82\%), porém responde por $29 \%$ do pessoal ocupado e $21 \%$ das remunerações (Tabela 3). 
Tabela 3 - Dados selecionados de empresas do setor de atendimento hospitalar por natureza jurídica-2011

\begin{tabular}{|c|c|c|c|c|c|}
\hline $\begin{array}{c}\text { Grupo da classificação de } \\
\text { atividades }\end{array}$ & $\begin{array}{c}\text { Empresas } \\
\text { e outras } \\
\text { organizações }\end{array}$ & $\begin{array}{c}\text { Pessoal } \\
\text { ocupado em } \\
31 / 12\end{array}$ & $\begin{array}{c}\text { N. médio } \\
\text { de pessoas } \\
\text { ocupadas em } \\
31 / 12\end{array}$ & $\begin{array}{c}\text { Salários } \\
\text { e outras } \\
\text { remunerações } \\
(\mathrm{R} \$ 1.000)\end{array}$ & $\begin{array}{l}\text { Salário médio } \\
(\mathrm{R} \$ 1.000)\end{array}$ \\
\hline \multicolumn{6}{|l|}{ VALOR } \\
\hline $\begin{array}{l}\text { Atividades de atendimento } \\
\text { hospitalar }\end{array}$ & 10.389 & 1.181 .224 & 113,7 & $28.827 .416,8$ & 24,4 \\
\hline Administração pública & 237 & 317.053 & $1.337,8$ & $10.146 .864,4$ & 32,0 \\
\hline Entidades empresariais & 8.587 & 344.736 & 40,1 & $6.212 .104,6$ & 18,0 \\
\hline Entidades sem fins lucrativos & 1.565 & 519.435 & 331,9 & $12.468 .447,8$ & 24,0 \\
\hline \multicolumn{6}{|l|}{ Porcentagem } \\
\hline $\begin{array}{l}\text { Atividades de atendimento } \\
\text { hospitalar }\end{array}$ & 100,0 & 100,0 & 100,0 & 100,0 & 100,0 \\
\hline Administração pública & 2,3 & 26,8 & $1.176,6$ & 35,2 & 131,1 \\
\hline Entidades empresariais & 82,7 & 29,2 & 35,3 & 21,5 & 73,8 \\
\hline Entidades sem fins lucrativos & 15,1 & 44,0 & 291,9 & 43,3 & 98,4 \\
\hline
\end{tabular}

Fonte: elaboração dos autores com base em dados do Cadastro Central de Empresas do IBGE.

As atividades de atenção ambulatorial executadas por médicos e odontólogos respondem por 49\% das empresas, $13 \%$ das pessoas ocupadas e $6 \%$ dos salários do setor. Porém, trata-se de um serviço que se confunde com as atividades de clínica médica e que, na maior parte das vezes, não apresenta organização empresarial de porte, como pode ser visto pelo tamanho médio em termos de pessoas ocupadas. O mesmo se pode dizer do setor de serviços profissionais, exceto médicos e odontólogos (19\% das empresas, 5\% das pessoas ocupadas e 3\% dos salários).

Já as atividades de serviços de complementação diagnóstica, que respondem por uma parcela de $16 \%$ das empresas, têm uma representatividade um pouco maior em termos de pessoas ocupadas e de salários (11\% e 7\%). Além disso, apresentam número médio de pessoas ocupadas e salário médio um pouco superior ao dos dois segmentos anteriores.

As informações apresentadas justificam a concentração da análise, no restante deste capítulo, nos setores associados diretamente aos seguros e planos de saúde, além dos segmentos de atendimento hospitalar e serviços de diagnóstico. Como será observado ao longo desta seção, são nesses segmentos que as mudanças mais importantes foram detectadas, justamente por comporem as atividades de maior porte e organização empresarial.

Evidências que confirmam o observado no parágrafo anterior podem ser analisadas com base nos dados da Tabela 4. Nesta tabela, estão as 25 maiores empresas associadas aos serviços de saúde, listadas entre as empresas da publicação Valor 1000 (<www.valor.com.br/valor1000/2015>), que reúne informações financeiras das mil maiores empresas brasileiras. 
É possível perceber como, apesar da estrutura pulverizada em termos de número de empresas, existem alguns grandes grupos que atuam nos diferentes segmentos, com volume de faturamento bastante elevado. A Amil aparece como maior empresa do setor, com receita líquida de R\$ 10,4 bilhões em 2012. Em seguida aparecem duas empresas de Seguro Saúde (Bradesco e Sul América) e somente na quarta posição um grupo com atividade hospitalar (Rede D’Or). Em termos de diagnóstico laboratorial, a Diagnósticos da América (Dasa) é a maior empresa e aparece na oitava posição entre as 25 maiores.

Tabela 4 - Receita líquida das 25 maiores empresas do setor de serviços de saúde, em R\$ milhões - 2012

\begin{tabular}{|l|l|c|}
\hline \multicolumn{1}{|c|}{ Empresa } & Segmento & Receita líquida \\
\hline AmilPar & Plano de saúde & $10.464,00$ \\
\hline Bradesco Saúde & Seguro saúde & $7.743,80$ \\
\hline Sul América Seguro Saúde & Seguro saúde & $5.431,20$ \\
\hline Rede D’Or & Serviços médicos & $3.122,10$ \\
\hline Unimed Rio & Plano de saúde & $2.773,40$ \\
\hline Hospitais São Paulo & Serviços médicos & $2.484,60$ \\
\hline NotreDame Intermédica & Plano de saúde & $2.349,20$ \\
\hline Diagnósticos da América & Serviços médicos & $2.264,10$ \\
\hline Unimed Paulistana & Plano de saúde & $2.232,30$ \\
\hline Unimed Belo Horizonte & Plano de Saúde & $2.144,40$ \\
\hline Golden Cross & Plano de saúde & $1.874,10$ \\
\hline Central Unimed Nacional & Plano de saúde & $1.631,80$ \\
\hline Sul América Saúde & Seguro saúde & $1.536,00$ \\
\hline Hospital Albert Einstein & Serviços médicos & $1.528,90$ \\
\hline Fleury Medicina e Saúde & Serviços médicos & $1.501,80$ \\
\hline Hospital Santa Catarina & Serviços médicos & $1.322,10$ \\
\hline Hospital e Maternidade São Camilo & Serviços médicos & $1.316,50$ \\
\hline Santa Casa de São Paulo & Serviços médicos & $1.117,60$ \\
\hline Unimed Curitiba & Plano de saúde & $1.113,80$ \\
\hline Unimed Porto Alegre & Plano de saúde & $1.095,30$ \\
\hline Unimed Campinas & Plano de saúde & $1.026,20$ \\
\hline Esho & Serviços médicos & $1.020,00$ \\
\hline Porto Seguro Saúde & Seguro saúde & 957,90 \\
\hline Odontoprev & Plano de saúde & 956,80 \\
\hline Hospital Santa Marcelina & Serviços médicos & 904,40 \\
\hline & & \\
\hline & &
\end{tabular}

Fonte: elaboração dos autores com base em dados do Valor 1000. 
Consolidando as informações das 25 maiores empresas por segmento (Tabela 5), nota-se que, do total de R 59,9 bilhões de receita líquida observado em 2012, as 11 empresas de planos de saúde responderam por $46 \%$, com receita média de $\mathrm{R} \$ 2,5$ bilhões. As empresas de seguro saúde tiveram receita média ainda maior ( $\mathrm{R} \$ 3,9$ bilhões), as quatro empresas listadas responderam por $26 \%$ da receita. As empresas de serviços médicos, que agregam tanto hospitais quanto empresas de diagnóstico, foram responsáveis pelos $27 \%$ da receita restante e tiveram a menor receita média entre os três segmentos ( $\mathrm{R} \$ 1,6$ bilhão).

Tabela 5 - As 25 maiores empresas do setor de serviços de saúde, por segmento, em R\$ milhões - 2012

\begin{tabular}{|l|c|c|c|}
\hline Segmento & N. de empresas & Receita líquida & Receita média \\
\hline Planos de saúde & 11 & $27.661,3$ & $2.514,7$ \\
\hline Seguros saúde & 4 & $15.668,9$ & $3.917,2$ \\
\hline Serviços médicos & 10 & $16.582,1$ & $1.658,2$ \\
\hline Total & 25 & $59.912,3$ & $2.396,4$ \\
\hline
\end{tabular}

Fonte: elaboração dos autores com base em dados do Valor 1000.

A seção seguinte analisa as mudanças pelas quais tem passado o setor de serviços de saúde no Brasil, resultantes em grande medida das estratégias empreendidas pelas maiores empresas do setor.

\section{Transformações recentes no mercado nacional}

As informações analisadas nesta seção procuram destacar o movimento de concentração pelo qual vem passando o setor. Esse processo teve início na década de 2000, porém tem se intensificado nos últimos anos em razão de dois movimentos simultâneos e muitas vezes interconectados. O primeiro está associado à busca dos grandes grupos internacionais por novos polos de expansão nos países em desenvolvimento, dado o forte movimento de consolidação já ocorrido nos países centrais, assim como à busca de mercados com maiores perspectivas de aumento da demanda. O segundo está relacionado ao crescente interesse dos fundos de private equity, tanto de capital nacional quanto estrangeiro, por oportunidades de investimento no mercado de serviços de saúde no Brasil.

Com base nas informações organizadas pela Agência Nacional de Saúde (ANS), é possível ter uma ideia mais clara do movimento de concentração no setor de seguros e planos de saúde. Em termos de número de operadores, pode-se perceber, no Gráfico 6, como a tendência desde 2011 tem sido de redução. Considerando os planos de saúde, o número diminuiu de 1.456 no final de 2001 para 929 em setembro de 2013 (redução de 36\%). Para os planos exclusivamente odontológicos, a redução foi de 505 para 345 no mesmo período (31\%). 
Gráfico 6 - Número de operadores de planos de saúde com beneficiários - dezembro 2009setembro 2013

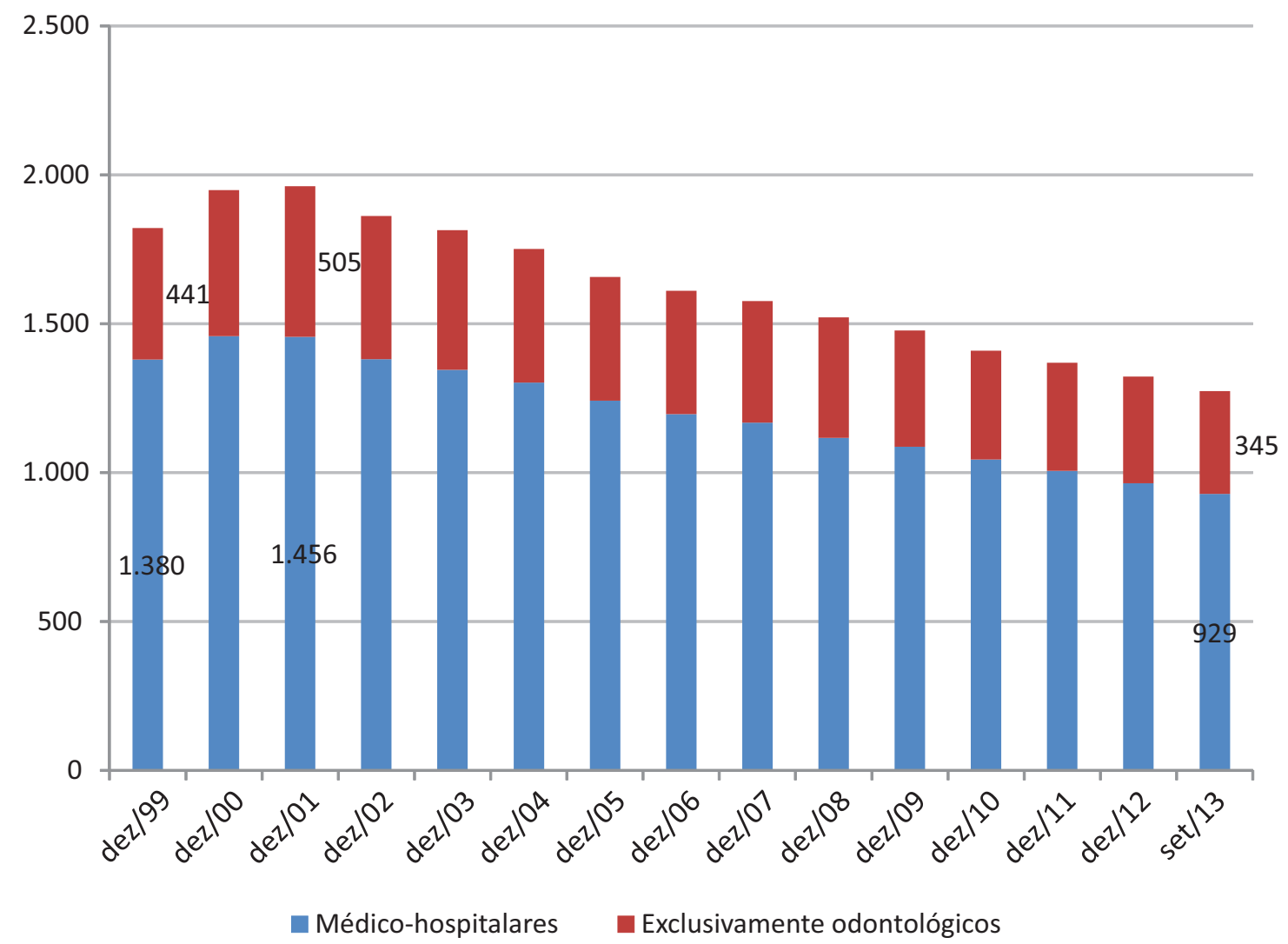

Fonte: elaboração dos autores com base em dados da ANS.

Interessante notar que a redução do número de operadores aconteceu ao mesmo tempo que o número de beneficiários passou por um aumento importante, fruto da expansão do nível de renda e do volume de emprego formal. De um total de cerca de 31 milhões de beneficiários de planos médico-hospitalares no início dos anos 2000, o total atingiu 49 milhões em setembro de 2013 (55\% de aumento). Para os planos exclusivamente odontológicos, a elevação foi ainda maior - saiu de 2,6 milhões e atingiu 19,5 milhões de beneficiários (aumento de 430\%) no mesmo período (Gráfico 7). 
Gráfico 7 - Número de beneficiários das operadoras de planos de saúde - dezembro 2000setembro 2013

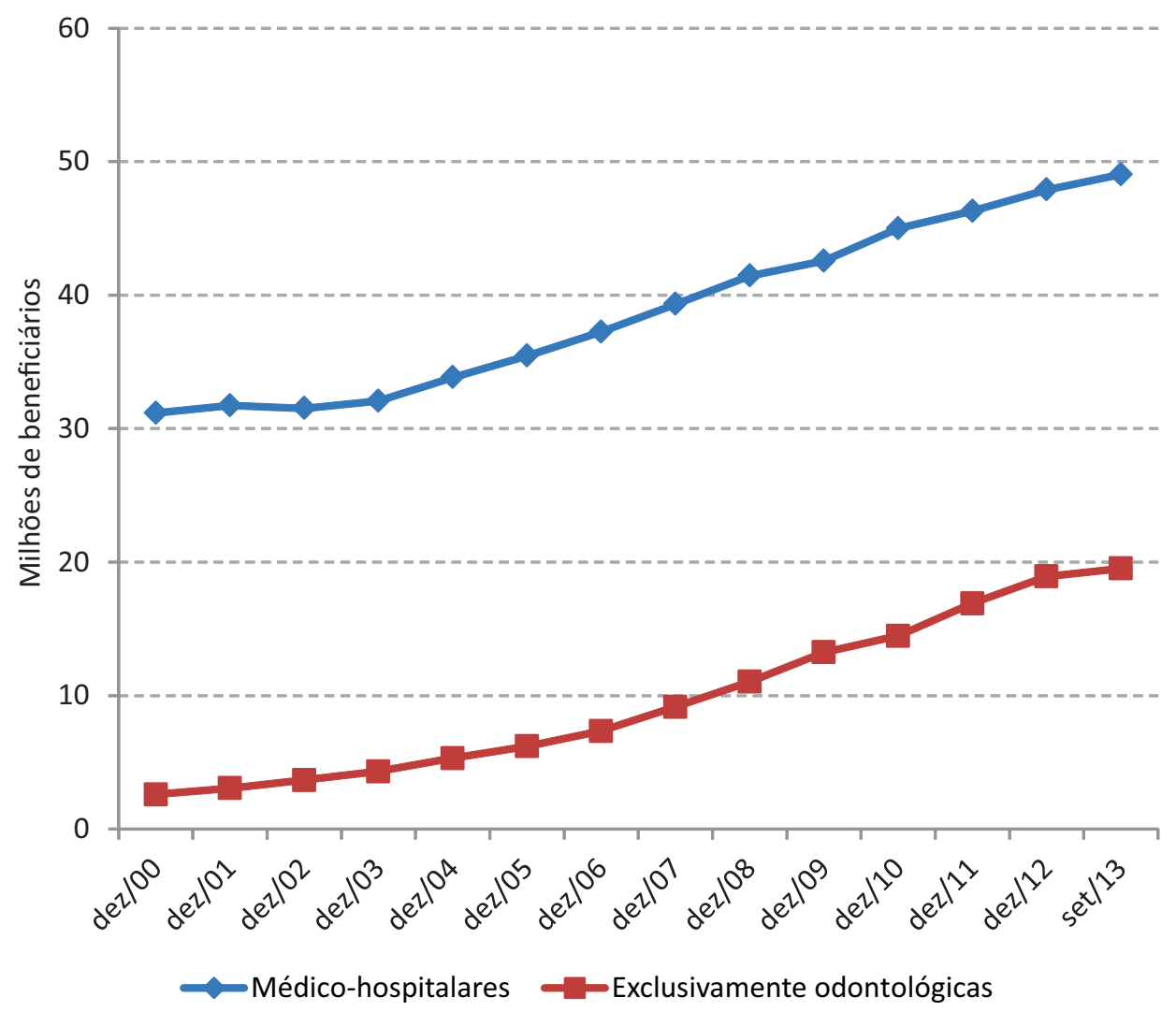

Fonte: elaboração dos autores com base em dados da ANS.

Como resultado do aumento do número de beneficiários e da redução do número de operadoras, o volume médio de beneficiários por operadora apresentou uma elevação consistente ao longo de todo o período - saiu de um patamar de 21,3 mil em 2000 para 52,7 mil em 2013. Observa-se, assim, um aumento importante nas escalas de operações do setor de planos de saúde (Gráfico 8).

Vale lembrar, porém, que, apesar do aumento da escala média, a disparidade entre os atores é bastante expressiva, pois ainda existe um número alto de empresas de pequeno porte atuando em mercados locais e regionais. Por sua vez, as grandes operadoras concentram parte importante das receitas e dos clientes. 
Gráfico 8 - Número médio de beneficiários por operadora de plano médico-hospitalar - dezembro 2000-setembro 2013

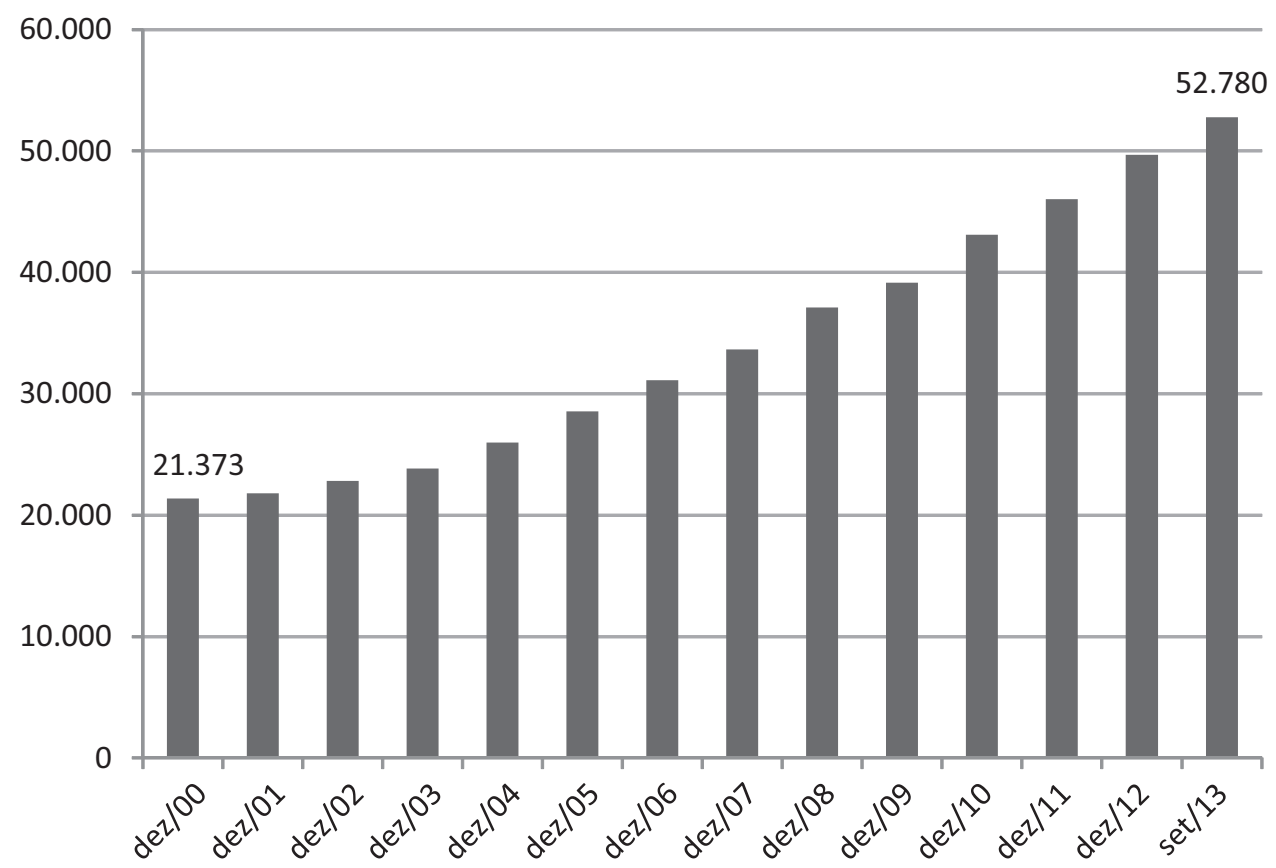

Fonte: elaboração dos autores com base em dados da ANS.

A Tabela 6 mostra como as duas maiores operadoras brasileiras atendem 14\% dos beneficiários. Caso sejam consideradas as quatro maiores, esse número chega a $21 \%$, e a $31,4 \%$ quando se consideram as oito maiores. Vinte e sete operadoras respondem por $50 \%$ dos 49 milhões de beneficiários.

Tabela 6 - Beneficiários de planos de saúde e percentual acumulado por operadora - 2012

\begin{tabular}{|c|c|c|}
\hline Número de beneficiários & Percentual acumulado de beneficiários & Operadoras \\
\hline Assistência médica com ou sem odontologia & & 2 \\
\hline 6.886 .753 & $14,0 \%$ & 4 \\
\hline 10.291 .181 & $21,0 \%$ & 8 \\
\hline 15.383 .274 & $31,4 \%$ & 15 \\
\hline 20.130 .399 & $41,1 \%$ & 27 \\
\hline 24.604 .478 & $50,2 \%$ & 51 \\
\hline 29.458 .303 & $60,1 \%$ & 95 \\
\hline 34.337 .273 & $70,0 \%$ & 168 \\
\hline 39.216 .981 & $80,0 \%$ & 306 \\
\hline 44.125 .239 & $90,0 \%$ & 926 \\
\hline 49.032 .912 & $100,0 \%$ & \\
\hline
\end{tabular}

Fonte: elaboração dos autores com base em dados da ANS. 
A concentração em termos de receita também pode ser constatada na Tabela 7. As grandes operadoras, que têm mais de 100 mil beneficiários, responderam por $71 \%$ da receita e por $68 \%$ dos beneficiários. Já nas operadoras exclusivamente odontológicas, as grandes responderam por 72\% das receitas e por cerca de $77 \%$ dos beneficiários.

Tabela 7 - Receita e beneficiários de operadoras de planos de saúde, por porte das operadoras - 2012

\begin{tabular}{|l|c|r|r|r|}
\hline Porte da operadora & Receita $(\mathrm{R} \$)$ & $\%$ & Beneficiários* & \multicolumn{1}{c|}{$\%$} \\
\hline OPERADORAS MÉDICO-HOSPITALARES & 93.122 & 100 & 51.702 .320 & 100,0 \\
\hline Pequeno (até 20.000 beneficiários) & 7.059 & 8 & 4.058 .379 & 7,8 \\
\hline Médio (20.000 a 100.000 beneficiários) & 19.955 & 21 & 12.157 .117 & 23,5 \\
\hline Grande (acima de 100.000 beneficiários) & 66.109 & 71 & 35.486 .824 & 68,6 \\
\hline OPERADORAS EXCLUSIVAMENTE ODONTOLÓGICAS & 2.295 & 100 & 14.846 .920 & 100,0 \\
\hline Pequeno (até 20.000 beneficiários) & 272 & 12 & 1.506 .359 & 10,1 \\
\hline Médio (20.000 a 100.000 beneficiários) & 360 & 16 & 1.924 .187 & 13,0 \\
\hline Grande (acima de 100.000 beneficiários) & 1.663 & 72 & 11.416 .374 & 76,9 \\
\hline Total & 95.417 & & 66.549 .240 & \\
\hline
\end{tabular}

* Dados preliminares

Fonte: elaboração dos autores com base em dados da ANS.

O processo de concentração no setor de planos de saúde caracterizou-se pela mesma busca de economias de escala, observada no cenário internacional, juntamente com a necessidade de atender a regulamentação com a criação da ANS em 2000. Além disso, é válido ressaltar que esse movimento foi acompanhado por mudanças no sentido da verticalização das atividades. Se, nos anos 1980 e 1990, a verticalização foi marcada pela oferta dos hospitais dos seus próprios planos de saúde, mais recentemente as operadoras têm buscado ampliar o número de hospitais próprios. Além de reduzir custos com o atendimento direto aos beneficiários, em especial os custos com internações, a existência de rede própria também aumenta o poder de negociação com outros fornecedores.

A Amil, por exemplo, vinha, mesmo antes de ser adquirida pela UnitedHealth, realizando um processo intenso de compra, tanto de outras operadoras como de hospitais. Entre essas aquisições, podem ser destacadas a Blue Life em 2007, a Ampla e a Casa de Saúde Santa Lúcia em 2008, a Medial em 2009, a Saúde Excelsior em 2010, o Samaritano e a Pasteur do Rio de Janeiro em 2011. Em 2013, a Amil tinha em sua rede própria 22 hospitais e 50 clínicas médicas, além de mais dois hospitais em construção.

A entrada de operadores internacionais no mercado brasileiro pode acentuar ainda mais o movimento de consolidação do setor, assim como reforçar a estratégia de verticalização. Do ponto de vista da atração de investidores estrangeiros, o fato que mais chamou a atenção foi a entrada da americana UnitedHealth no Brasil ao comprar a Amil. O negócio foi fechado após um longo período de negociações. De acordo com informações da imprensa especializada, a venda de $90 \%$ do seu capital à UnitedHealth foi avaliada em R 9,8 bilhões. Além do valor da transação, a operação marcou 
a entrada da maior operadora de planos de saúde do mundo no mercado brasileiro. Como mostrado na terceira seção deste capítulo, em 2012 o faturamento da UnitedHealth atingiu cerca de US\$100 bilhões (enquanto o da Amil atingiu cerca de US\$ 5,1 bilhões).

De acordo com reportagem do jornal Valor Econômico, de 7 de agosto de 2013 (Koike, 2013a), após a aquisição pela UnitedHealth, a Amil negociava a compra de outros hospitais, com o objetivo não só de ampliar sua rede própria, consolidando a estratégia de verticalização, mas também de expandir sua abrangência em regiões onde a operadora ainda tem presença pequena.

Pode-se também registrar o interesse de outras empresas, como a Colsanitas, pertencente à holding colombiana Organizacion Sanitas Internacional (OSI). Em 2011, a Colsanitas comprou 45\% da operadora brasileira Universal Saúde e recentemente anunciou a intenção de aumentar a participação para 80\%. Segundo notícias veiculadas na imprensa, o objetivo do grupo no mercado brasileiro é comprar outras operadoras de planos de saúde e montar uma rede própria de hospitais e clínicas, nos moldes do que possui na Colômbia.

Boatos sobre a compra da Golden Cross pelo fundo norte-americano KKR também circularam na imprensa em 2012, embora efetivamente não tenha se concretizado nenhuma operação.

Em março de 2014, a terceira maior operadora de planos de saúde do Brasil teve uma das unidades do grupo adquirida por um grupo estrangeiro. O grupo NotreDame Intermédica vendeu a Intermédica para o fundo estadunidense de private equity Bain Company. Embora o valor oficial da operação não tenha sido revelado, a imprensa noticiou a cifra de US\$ 2 bilhões.

A participação de fundos de investimento no setor de saúde é outra novidade que tem contribuído para acelerar as transformações do setor de serviços de saúde privados no Brasil. Além da entrada da Bain Company adquirindo a Intermédica, podem ser citados vários outros exemplos de participação dos fundos de private equity no setor.

Um dos principais exemplos é a capitalização da empresa de medicina diagnóstica Hermes Pardini. Após a venda de 30\% de seu capital para o Gávea em 2011, a Hermes Pardini iniciou um processo de aquisições, em que se destaca a compra de $70 \%$ do capital da Diagnóstika, laboratório paulista especializado em exames de alta complexidade, com receita estimada de $\mathrm{R} \$ 27$ milhões. Além disso, anunciou a compra de $80 \%$ do Padrão, laboratório de Goiás com receita de R 50 milhões. Em 2012, fechou três aquisições: Digimagem (SP), Progenética (RJ) e o mineiro Biocod (Moura \& Koike, 2013).

Após intensa negociação envolvendo fundos de private equity nacionais e estrangeiros para a aquisição do controle do segundo maior laboratório do país, o Fleury. A Core Participações, formada pelos médicos que detêm o controle do Fleury, consolidou a venda de 13\% das ações para o fundo Advent. A disputa pelo Laboratório Fleury demonstra como os fundos financeiros vêm focando suas estratégias em aquisições de empresas de serviços de saúde em países em desenvolvimento.

O fundo Pátria, por sua vez, decidiu montar uma empresa no setor de exames de imagen, a Alliar, em 2011. Anteriormente, o Pátria tinha participação no grupo Dasa, porém desfez-se de sua participação em 2009. Entre 2013 e 2015, a Alliar realizou 11 aquisições de outros laboratórios de 
exames de imagem. As aquisições foram feitas em grande parte por meio da troca de ações das empresas adquiridas por ações da Alliar.

Na contramão dos movimentos anteriores, a Dasa registrou em 2014 o aumento da participação do empresário Edson Bueno e sua ex-mulher Dulce Pugliesi, antigos controladores da Amil. Com a aquisição de 48,35\% por R $\$ 2,3$ bilhões, a participação dos novos controladores saltou para 71,94\%. Fundos como Tarpon, Petros e Oppenheimar, tiveram, assim, sua participação diminuída no capital total do grupo (Koike, 2014).

No caso dos hospitais, o movimento de consolidação é relativamente mais lento em relação aos demais segmentos do setor de serviços. A existência de um grande número de hospitais sem fins lucrativos, aliada à restrição legal de participação de capital estrangeiro, tem reduzido os processos de fusão e aquisição. No entanto, cabe destacar que o maior grupo privado no setor, o Rede D'Or, tem adotado uma estratégia mais agressiva. De acordo com reportagem do jornal Valor Econômico, de 3 de abril de 2013 (Koike, 2013b), o grupo realizou 17 aquisições nos cinco anos anteriores, praticamente dobrando o faturamento entre 2010 e 2012 . Nesse processo, foi importante a parceria do BTG Pactual, que, além de ter participação minoritária, auxiliou o grupo hospitalar no lançamento de debêntures para financiar a expansão e também tem assessorado o grupo no processo de aquisições.

Essa intensa movimentação no setor de serviços de saúde pode também ser observada com a análise dos números referentes a fusões e aquisições no Brasil. ${ }^{3}$ No caso específico dos setores selecionados, as informações coletadas mostram uma tendência de aumento no número de operações, que vão atingir o volume máximo em 2008, com posterior redução no período pós-crise, porém mantendo um número de operações importantes. Em termos de valores, é possível verificar como estes atingem patamares mais elevados a partir de 2008, chegando ao valor máximo em 2012 (Gráfico 9).

\footnotetext{
${ }^{3}$ As informações sobre os processos de fusões e aquisições no Brasil foram coletadas na base de dados Zephir produzida pela empresa Bureau van Dijk (BvD).
} 
Gráfico 9 - Número e valor das operações de fusões e aquisições de empresas do setor de serviços de saúde no Brasil, em US\$ milhões - 2004-2013

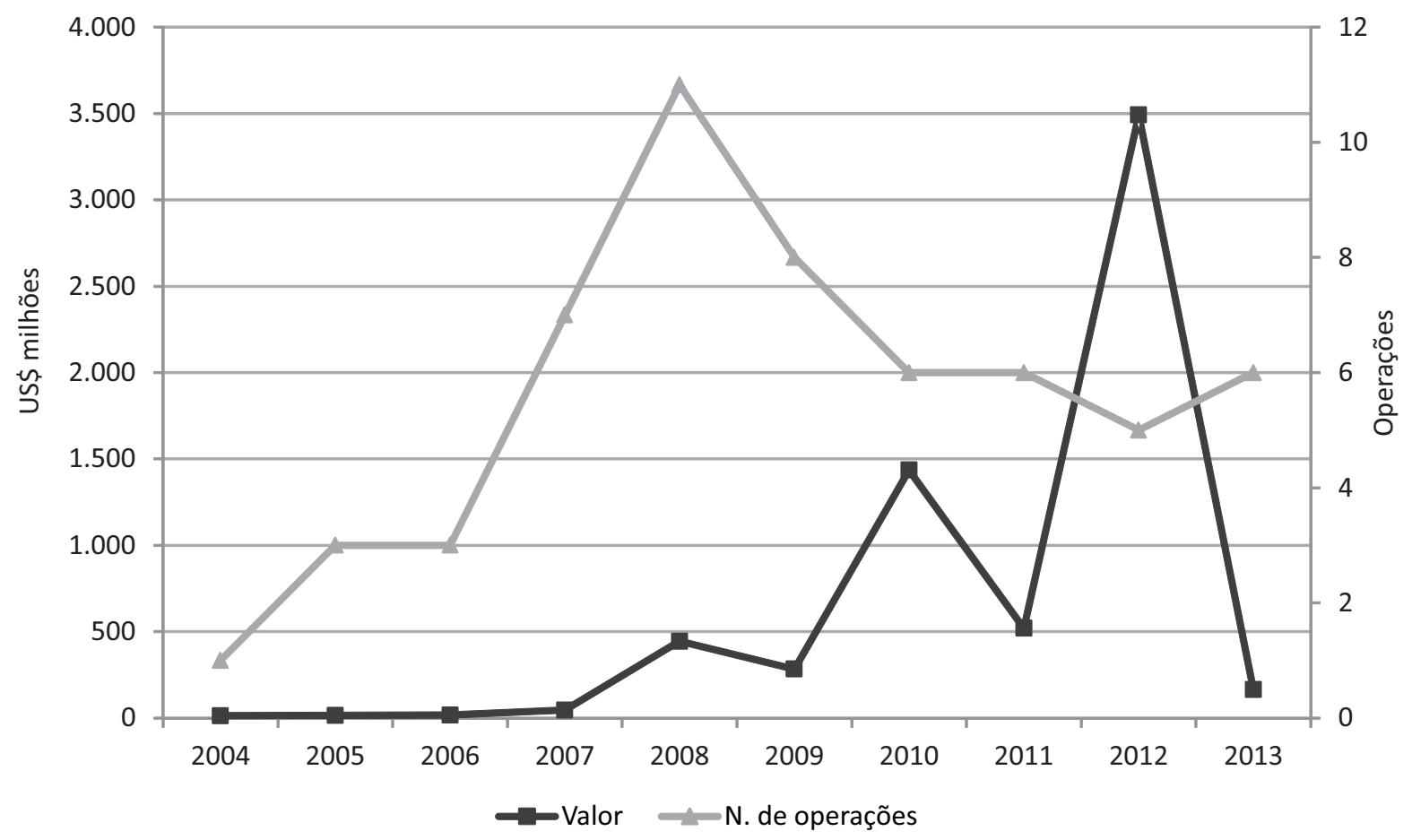

Fonte: elaboração dos autores com base em dados da Zephir-Bureau van Dijk (BvD).

Considerando o total de operações acumuladas entre 2004 e 2013, dos 58 registros encontrados, 23 não tinham registros de valor. A maior parte das operações se concentrou na faixa dos US\$ 10 a US\$ 50 milhões. Duas operações tiveram registro acima de US\$ 1 bilhão, e três na faixa entre US\$ 200 milhões e US\$ 1 bilhão (Tabela 8).

Tabela 8 - Operações de fusões e aquisições no Brasil no setor de serviços de saúde, por valor de operação - 2004-2013

\begin{tabular}{l|c|}
\hline Acima de US\$ 1 bilhão & 2 \\
\hline Entre US\$ 200 milhões e US\$ 1 bilhão & 3 \\
\hline Entre US\$ 50 e US\$ 200 milhões & 6 \\
\hline Entre US\$ 10 e US\$ 50 milhões & 15 \\
\hline Até US\$ 10 milhões & 9 \\
\hline Sem valor informado & 23 \\
\hline Total & 58 \\
\hline
\end{tabular}

Fonte: elaboração dos autores com base em dados da Zephir-Bureau van Dijk (BvD).

A grande maioria das operações ainda diz respeito a fusões e aquisições que envolvem empresas nacionais (Tabela 9). Porém, a participação de estrangeiros vem se tornando mais comum. Além 
disso, também vale destacar que, como mostra a entrada da UnitedHealth e da Bain Company em 2014 (ainda não captada na Tabela 9), em geral a entrada das estrangeiras acontece em grandes operações, que têm impactos relevantes sobre a estrutura do setor.

Tabela 9 - Operações de fusões e aquisições no Brasil no setor de serviços de saúde, por origem da adquirente, em US\$ milhões - 2004-2013

\begin{tabular}{|l|c|c|}
\hline \multicolumn{1}{|c|}{ Origem } & Operações & Valor \\
\hline Nacionais & 53 & $3.084,0$ \\
\hline Estrangeiros & 5 & $3.346,6$ \\
\hline França (2011) & 1 & n. d.* \\
\hline Estados Unidos (2012) & 1 & $3.207,9$ \\
\hline Canada (2012) & 1 & 120,7 \\
\hline Espanha (2013) & 1 & n. d. \\
\hline Colômbia (2013) & 1 & 18,0 \\
\hline Total & 58 & $6.430,6$ \\
\hline
\end{tabular}

*n. d. = não divulgado

Fonte: elaboração dos autores com base em dados da Zephir-Bureau van Dijk (BvD).

As operações captadas por empresa adquirente mostram uma concentração relativamente importante das aquisições entre as grandes empresas do setor. Interessante notar também que a comparação entre o número de operações registrado na base de dados e as informações colhidas na imprensa especializada permite intuir que as operações registradas pela Zephir-Bureau van Dijk (BvD) estão subestimadas, registrando apenas as maiores aquisições do setor. Por exemplo, a Rede D’Or aparece com apenas três operações na Tabela 10, enquanto outras fontes informam17 aquisições.

Tabela 10 - Operações de fusões e aquisições no Brasil no setor de serviços de saúde, por principais empresas - 2004-2013

\begin{tabular}{|l|c|c|}
\hline \multicolumn{1}{|c|}{ Adquirente } & Operações & Valor (US\$ milhões) \\
\hline Dasa & 13 & $1.218,9$ \\
\hline Fleury & 7 & 442,7 \\
\hline Amil/Amil participações & 4 & 501,6 \\
\hline Odontoprev & 4 & 38,8 \\
\hline Grupo Bradesco & 3 & 432,8 \\
\hline Rede D'Or & 3 & 163,4 \\
\hline Hermes Pardini & 3 & n. d* \\
\hline Sacmil & 3 & n.d \\
\hline Sul América & 3 & 33,6 \\
\hline Qualicorp & 2 & n. d \\
\hline
\end{tabular}

\footnotetext{
* n. d. = não divulgado.
}

Fonte: elaboração dos autores com base em dados da Zephir-Bureau van Dijk (BvD). 
Os dados analisados nesta seção, apesar das diferenças, finalizam um processo intenso de alterações na estrutura do setor de serviços de saúde. O movimento de consolidação no segmento de planos de saúde foi bastante intenso nos últimos anos, embora ainda exista um conjunto de operadores menores que podem ser alvo de novos movimentos no futuro. Também no setor de serviços de laboratório e diagnóstico, constata-se um acentuado processo de concentração. A capitalização por fundos de investimentos nacionais e internacionais tem sido um potente alavancador do movimento de consolidação.

O segmento menos sujeito ao processo, embora tenha passado também por um movimento de fusões e aquisições, é justamente o segmento hospitalar. Este setor tem se deparado, por um lado, com a busca por redução de custos e a estratégia de verticalização dos planos de saúde; por outro, tem enfrentado elevação de custos importantes, em especial no caso do avanço em tecnologias complexas, ${ }^{4}$ como forma de atingir segmentos de renda mais elevada. Essa situação tem levado vários hospitais menores a uma situação financeira delicada, o que afeta também o número de leitos colocados à disposição pelo setor privado.

Aparentemente, o movimento de consolidação em serviços de saúde ainda pode ter desdobramentos importantes no futuro, com implicações também importantes sobre as agências reguladoras e sobre os diversos níveis da política pública voltada para o setor.

\section{Mudanças Estruturais nos Serviços de Saúde}

Estas considerações finais têm o objetivo apenas de apontar de maneira preliminar algumas questões relativas às consequências do movimento descrito nas seções anteriores. Longe de ser um levantamento exaustivo, trata-se apenas de um primeiro esforço de análise, que deve necessariamente ser complementado através do diálogo com outros estudos sobre o setor.

Em primeiro lugar, cabe destacar o desafio colocado para as agências reguladoras. Em relação ao Conselho Administrativo de Defesa da Concorrência (Cade), os vários processos de concentração no setor têm sido objeto de crescente atenção da entidade, com a preocupação de reduzir o poder de mercado resultante das fusões e aquisições.

O desafio maior, no entanto, cabe à ANS. A busca por escala e melhores condições de custo e rentabilidade move o processo de concentração do setor, impulsionado inclusive por movimentos de capitalização advindos do processo de internacionalização de empresas e fundos financeiros em busca de novos espaços de valorização. Se, por um lado, esse movimento pode permitir investimentos em expansão e melhora de eficiência produtiva, por outro, pode acarretar práticas de elevação de preços, discriminação de preços, excluindo clientes de renda mais baixa do acesso a procedimentos mais sofisticados, racionalização excessiva, até mesmo em termos de mão de obra, reduzindo a qualidade do atendimento.

A inclusão de novos atores, como grandes grupos estrangeiros e fundos financeiros, reforça essa tensão, na medida em que aumenta o poder econômico dos agentes atuantes no setor e, ao mesmo

\footnotetext{
${ }^{4}$ O robô cirúrgico Da Vinci, por exemplo, tem custo estimado entre US\$ 1,5 e 3 milhões, somente da máquina, sem contar custos de treinamento e manutenção.
} 
tempo, induz a transferência de mecanismos de gestão que pressionam por maiores retornos e busca de eficiência operacional. $\mathrm{O}$ aumento do porte dos grupos privados com certeza exigirá maior capacidade de resposta da ANS, assim como será necessário que a agência consiga se antepor aos interesses puramente privados para poder gerar consequências positivas para a população atendida.

Do ponto de vista do controle dos hospitais, a aquisição das operadoras de planos de saúde por agentes estrangeiros cria uma situação de concorrência em que essa influência necessariamente será sentida. A concentração no setor de planos de saúde e a busca por redução de custos significam, sob a ótica dos hospitais, uma dificuldade para aumentar a receita. Essa pressão pode levar, por um lado, à replicação do movimento de consolidação no próprio setor de hospitais, como mostra a estratégia do grupo D'Or. Por outro, deve reforçar a necessidade de reduzir os custos sobre o restante da cadeia de fornecimento, fato que pode resultar em piora na qualidade, assim como em dificuldade de expandir o número de leitos. Em uma situação em que a pressão pelo aumento de leitos deve continuar aumentando, esse fator pode intensificar ainda mais a necessidade de investimentos públicos na expansão de sua rede de atendimento hospitalar.

Finalmente, cabe destacar que o movimento de internacionalização e concentração do setor privado de serviços de saúde também representa desafios para a articulação que está sendo organizada para o desenvolvimento do complexo industrial da saúde. Atores que atuam com uma lógica global tendem a reforçar laços com fornecedores globais de produtos, equipamentos, insumos e serviços tecnológicos, forçando um timing que pode ir de encontro ao esforço de construir capacidades produtivas e tecnológicas locais.

\section{Referências}

ARROW, K. J. Uncertainty and the welfare economics of medical care. The American Economic Review, 53(5): 941-970, 1963.

CHESNAIS, F. A Mundialização do Capital. São Paulo: Xama, 1996.

CONILL, E. M. Sistemas comparados de saúde. In: CAMPOS, G. W. S. et al. (Orgs.). Tratado de Saúde Coletiva. São Paulo, Rio de Janeiro: Hucitec, Editora Fiocruz, 2008.

IUNES, R. F. Demanda e demanda em saúde. In: PIOLA, S. F. \& VIANNA, S. M. (Orgs.). Economia da Saúde: conceitos e contribuição para a gestão da saúde. Brasília: Ipea, 1995.

JENSEN, M. Eclipse of the public corporation. Harvard Business Review, 67(5): 61-74, Sept-Oct. 1989.

KOIKE, B. Sob comando da UnitedHealth, Amil negocia compra de hospitais. Valor Econômico. São Paulo, 7 ago. 2013a. Disponível em: <www.valor.com.br/empresas/3224594/sob-comando-da-unitedhealth-amil-negociacompra-de-hospitais $>$.

KOIKE, B. Rede D’Or vai investir 500 milhões. Valor Econômico, São Paulo, 3 abr. 2013b. Disponível em: <http:// www.valor.com.br/empresas/3070998/rede-dor-vai-investir-r-500-milhoes>. Acesso em: março 2014.

KOIKE, B. Edson Bueno fica com 71,94\% da Dasa após investimento de R\$2,3 bi. Valor Econômico. São Paulo, 12 mar. 2014. Disponível em: <www.valor.com.br/empresas/3477080/edson-bueno-fica-com-7194-da-dasaapos-investimento-de-r-23-bi> . Acesso em: 15 mar. 2014.

MARKETLINE INDUSTRY PROFILE. Global Healthcare Providers. London: Marketline, 2013. 
MOURA, M \& KOIKE, B. Hermes Pardini fecha quinta aquisição e vai comprar mais. Valor Econômico. São Paulo, 24 jul. 2013. Disponível em: <www.valor.com.br/empresas/3208588/hermes-pardini-fecha-quinta-aquisicaoe-vai-comprar-mais>. Acesso em: março 2014.

PETERSON, J. New laws and rising costs create a surge of supersizing hospitals. The New York Times. New York, 12 ago. 2013.

SARTI, F. \& HIRATUKA, C. Indústria mundial: mudanças e tendências recentes. Texto para discussão IE-Unicamp, n. 186, 2010. Disponível em: <www.eco.unicamp.br/docdownload/publicacoes/textosdiscussao/texto186. pdf >. Acesso em: março 2014.

UNITED NATIONS CONFERENCE ON TRADE ANDE DEVELOPMENT (UNCTAD). World Investment Report 2004: the shift towards services. Geneva: UNCTAD, 2004. 


Formato: $21 \times 26 \mathrm{~cm}$

Tipologia: Candara e Charter

Papel: Print Max 90g/ $\mathrm{m}^{2}$ (miolo)

Cartão supremo $250 \mathrm{~g} / \mathrm{m}^{2}$ (capa)

CTP, Impressão e acabamento: Imos Gráfica e Editora Ltda.

Rio de Janeiro, setembro de 2016

Não encontrando nossos títulos em livrarias, contactar a EDITORA Fiocruz:

Av. Brasil, 4036, térreo, sala 112 - Manguinhos

21040-361 - Rio de Janeiro, RJ

Tel.: (21) 3882-9039 e 3882-9041 - Telefax: (21) 3882-9006

www.fiocruz.br/editora

editora@fiocruz.br 

Pensar, hoje, o Brasil para os próximos vinte anos parece tarefa impossível, sobretudo se considerarmos a persistência da crise econômica internacional e a situação econômica do país. Apesar da dificuldade, os autores desta obra, de leitura obrigatória, ousaram refletir sobre o que seria esse Brasil distante, tendo como compromisso primeiro a melhoria da saúde pública, o que envolve o desenvolvimento pleno do Sistema Único de Saúde.

O que nos é apresentado não é simplesmente a conformação de uma saúde pública que considere as tendências de longo prazo que estão postas em vários campos - entre os quais destaco a demografia -, a gestão e os constrangimentos derivados de um mundo globalizado e dominado pelas finanças. Trata-se de pensar o futuro que queremos construir, no qual a saúde é peça-chave, tendo como elemento inspirador o tipo de sociedade em que desejamos viver daqui a vinte anos.

Rosa Maria Marques

Professora titular de economia da Pontifícia Universidade Católica de São Paulo e presidente da Associação Brasileira de Economia da Saúde

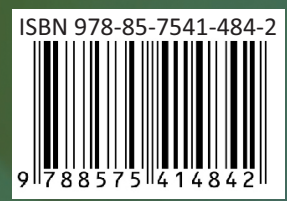

